\title{
Chad: Selected Issues and Statistical Appendix
}

This Selected Issues paper and Statistical Appendix for Chad was prepared by a staff team of the International Monetary Fund as background documentation for the periodic consultation with the member country. It is based on the information available at the time it was completed on December 4, 2006. The views expressed in this document are those of the staff team and do not necessarily reflect the views of the government of Chad or the Executive Board of the IMF.

The policy of publication of staff reports and other documents by the IMF allows for the deletion of market-sensitive information.

To assist the IMF in evaluating the publication policy, reader comments are invited and may be sent by e-mail to publicationpolicy@imf.org.

Copies of this report are available to the public from

International Monetary Fund • Publication Services

700 19th Street, N.W. • Washington, D.C. 20431

Telephone: (202) 6237430 • Telefax: (202) 6237201

E-mail: publications@imf.org • Internet: http://www.imf.org

Price: $\$ 18.00$ a copy

\section{International Monetary Fund Washington, D.C.}





\title{
INTERNATIONAL MONETARY FUND
}

\author{
CHAD
}

\section{Selected Issues and Statistical Appendix}

Prepared by T. Strauss, S. Lacoche, T. Dabán (all AFR),

D. Kovtun, L. Redifer (all PDR), W. Camard (IMF Resident Mission in Chad), and Ngueto

Yambaye (Economist at the IMF's office in Chad)

Approved by the African Department

December 4, 2006

Contents

Page

Introduction

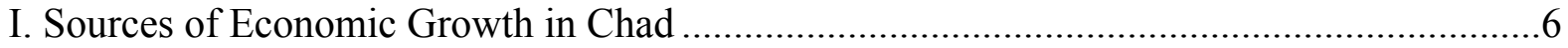

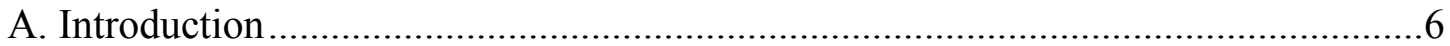

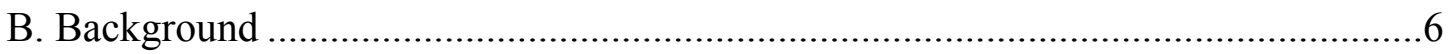

C. Factors of Economic Growth in Chad and Peer Groups ....................................... 7

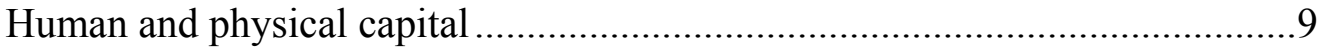

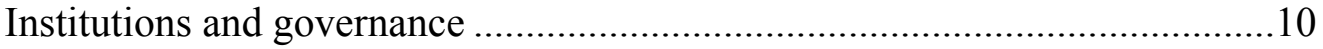

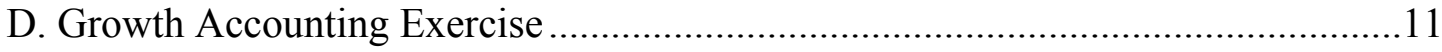

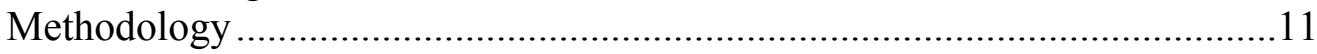

E. Will the Oil Sector Help Boost Chad's Growth? ................................................14

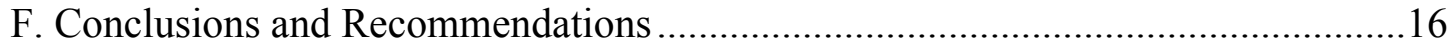

II. Chad: Dimensions of Poverty and Distribution of Oil Revenue ................................... 19

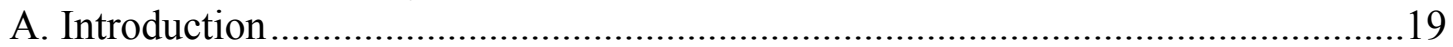

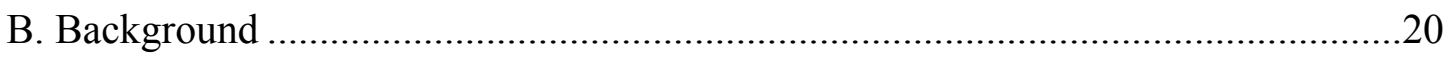

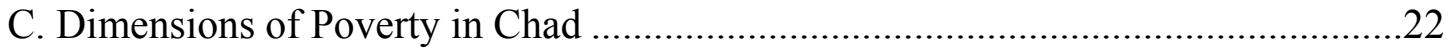

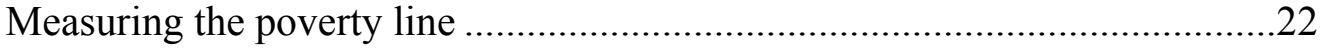

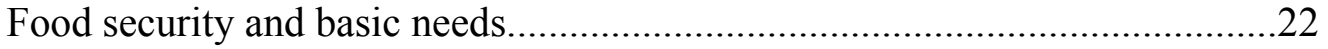

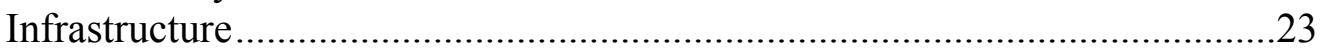

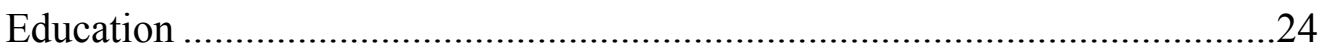

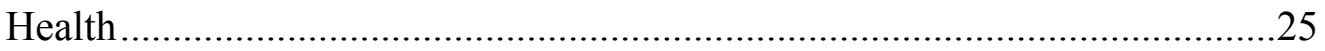

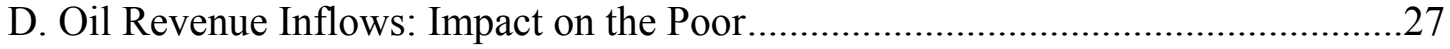

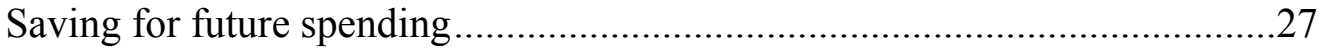

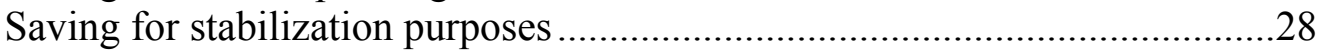


Public expenditure, efficiency, and absorptive capacity.................................28

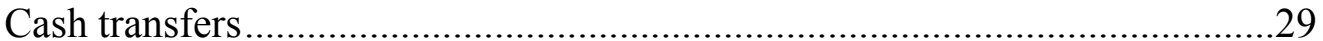

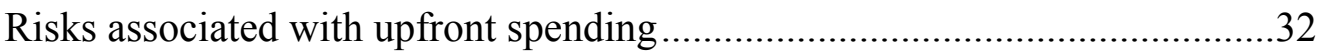

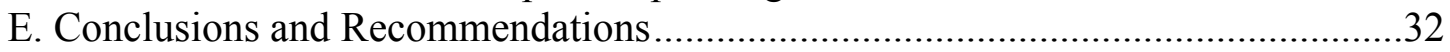

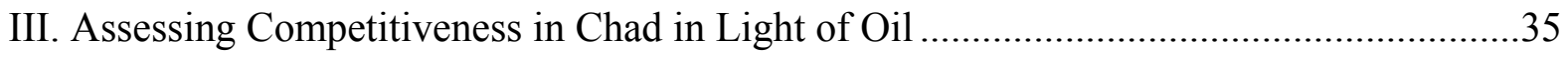

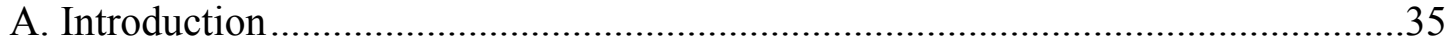

B. The External Sector Through 2004 .........................................................................35

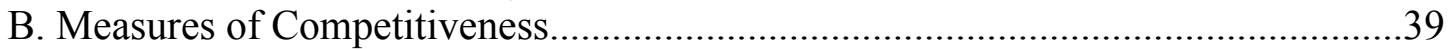

C. Possible Policy Responses to Declining Competitiveness .........................................43

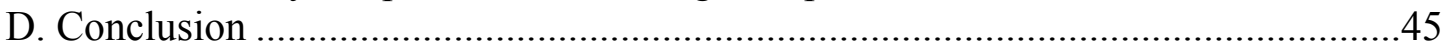

IV. Fiscal Policy and Oil revenues Management: The case of Chad.......................................4

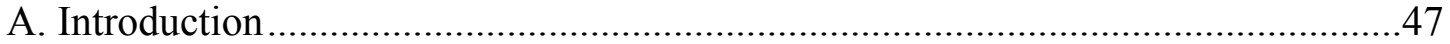

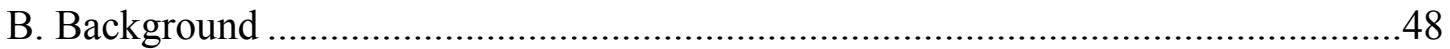

The oil sector operators............................................................................... 48

The Petroleum Revenue Management Program ……………………................52

C. Lessons from PRMP Implementation in Chad........................................................55

D. Chad's Oil Sector Developments and Prospects.....................................................56

E. Long-term Fiscal Strategy Options for Chad .........................................................62

F. A Sound Institutional Framework for Chad Long-Term Fiscal Policy .....................71

Rationale and General Principles............................................................................

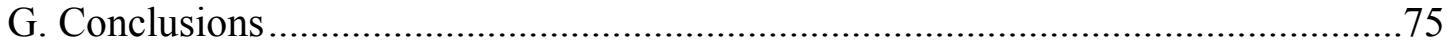

Annex I. Legal Framework for Petroleum Revenue Management in Chad ....77

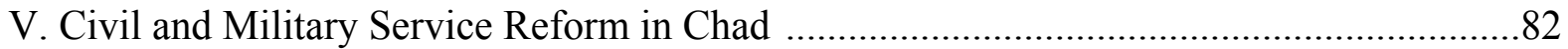

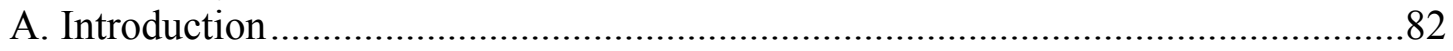

B. Civil and Military Service Reform Strategy, Implementation ..................................83

C. Main Characteristics of Chad's Civil and Military Service ......................................87

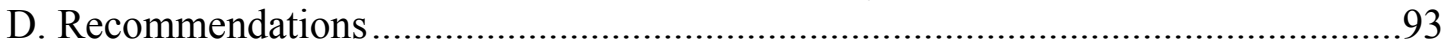

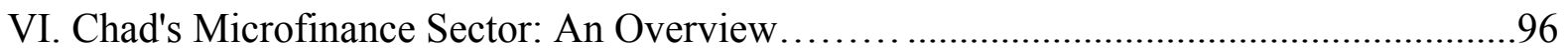

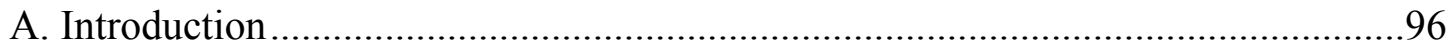

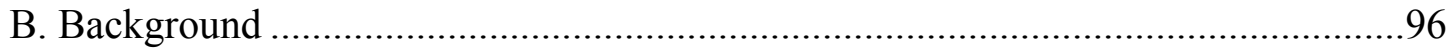

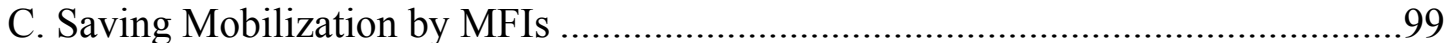

D. Weaknesses and Challenges of Chad's Microfinance Sector................................100

E. Conclusiones and Recommendations .................................................................101

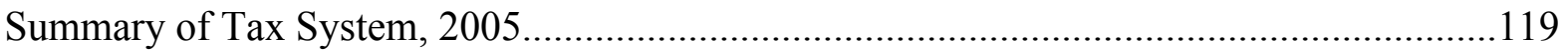

Statistical Appendix Tables

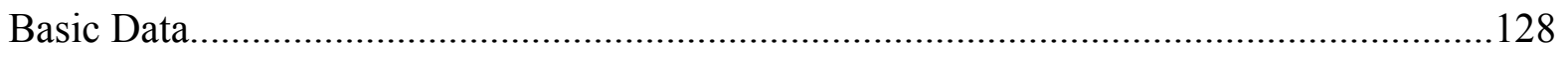

Statistical Tables 
1. Gross Domestic Product by Sector of Origin, 1998-2005

(at current prices)

2. Gross Domestic Product by Sector of Origin, 1998-2005

(at constant prices)....

3. Supply and Use of Resources at Current Prices, 1998-2005

(in billions of CFA francs).

4. Supply and Use of Resources at Current Prices, 1998-2005

(in percent of GDP)

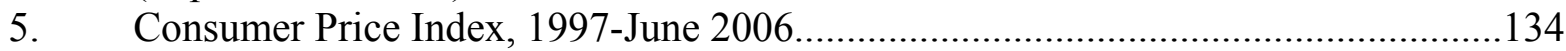

6. Production of Main Food Crops, 1994/95-2004/05 ..................................................135

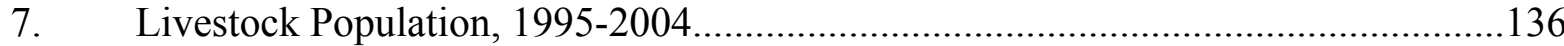

8. Summary of Table of Cotton Indicators, 1994/95-2004/05 .....................................137

9. Cotton Production, Cost, and Revenue, 1997/98-2004/05 ......................................138

10. Cost Structure of Cotton Processing and Marketing, 1994/95-2003/04....................139

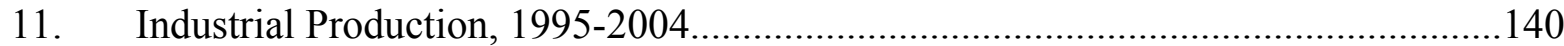

12. Distribution and Consumption of Water and Electricity, 1995-2004........................141

13. Consolidated Government Operations, 1998-2005 (CFAF francs)...........................142

14. Consolidated Government Operations, 1998-2005 (percent of non-oil GDP).........143

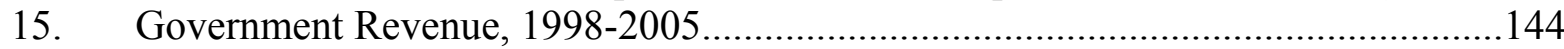

16. Economic Classification of Central Government Expenditure, 1998-2005...............145

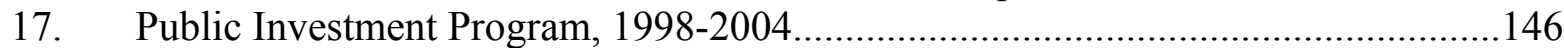

18. Central Government Employment, 1998-2004 ......................................................147

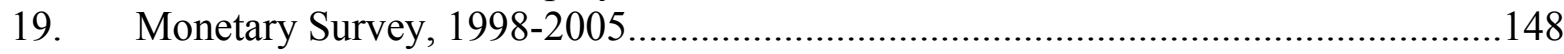

20. Summary Accounts of the Central Bank, 1998-2004 .............................................149

21. Balance Sheet of Commercial Banks, 1998-2004................................................150

22. Net Claims of the Banking System on Government, 1998-2004............................151

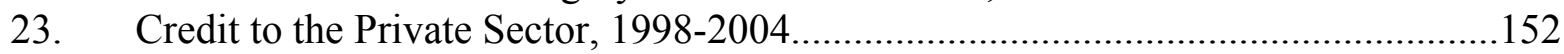

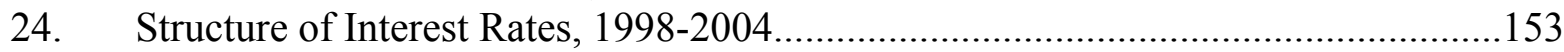

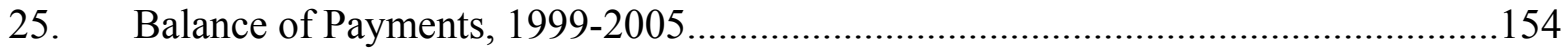

26. External Financial Assistance, 1999-2005............................................................155

27. Public and Publicly Guaranteed External Debt Outstanding, 1999-2005.................156

28. Services, Income, and Current Transfers in the External Accounts, 1999-2005 ....157

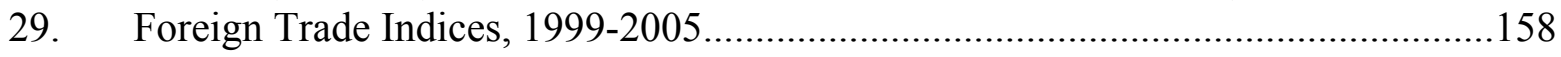

30. Exchange Rates, 1998-Second Quarter 2006 ....................................................159

31. CEMAC: Indicators of Fiscal Balance, 1998-2005 .............................................160

32. CEMAC: Indicators of External Balance, 1998-2005 ...........................................161

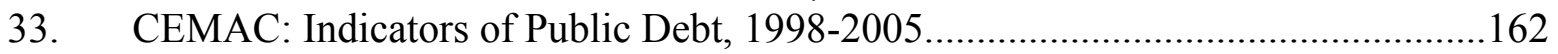




\section{Introduction}

Chad's socio-economic indicators rank among the lowest in the world. Disadvantages stemming from its geographical position and harsh natural conditions have been compounded by continuing armed conflict since independence in 1960. Oil revenue from the recently started oil project provides an unprecedented opportunity, but its efficient and effective management poses serious challenges for Chad's weak administration and political system.

This set of Selected Issues Papers aims at discussing the impact of the oil windfall on Chad, with a focus on growth, poverty, competitiveness, and fiscal policy challenges posed by the oil revenue outlook, and the reforms needed to remove structural factors that constraints non-oil sector growth, in particular on civil and military services and microfinance sector.

Chapter I argues that Chad's current growth potential is seriously limited by low levels of both human and physical capitals and by weak institutions and governance. The direct impact of the petroleum sector is limited because the sector is not well integrated into the local economy. The government's oil-financed budget programs are therefore the main channel to have a sizeable and lasting impact on poverty. However, to preserve macroeconomic stability, oil-financed spending programs must be accompanied by prudent macroeconomic policies and structural measures to improve the absorptive capacity of the economy and promote non-oil growth.

Chapter II provides a comprehensive view of the different dimensions of poverty in Chad and discusses alternative strategies to overcome poverty through an appropriate use of oil revenues over time. It argues that given Chad's low capital stock and potential positive government spending externalities, oil revenues should be spent early on rather than saved for future generations. The frontloaded nature of the desired spending profile would, however, depend on improvements in macroeconomic and absorptive capacity. In this regards, the paper singles out the implementation of a well-prepared medium-term expenditure framework as an essential reform to allow proper budget planning and allocation of expenditures towards priority sectors.

Chapter III concludes that there are some signs of real exchange rate appreciation, although the period for which data are available is very short and the data quality is weak. Given Chad's membership in the CEMAC, the Chadian authorities have limited recourse to monetary and fiscal policies to neutralize real exchange rate appreciation, thus structural policies will need to play a key role in maintaining competitiveness. In the end, the most important and effective policies to retain or boost competitiveness will be those to facilitate an increase in productivity in the non-oil economy.

Chapter IV argues that Chad's long-term fiscal strategy should aim at managing nonoil revenue and expenditure in a way to compensate for the depletion of oil revenues. The strategy should imply the adoption of a (i) sustainable long-term fiscal policy that- 
against the background of Chad's relative small and finite oil reserves - could entail the full yet gradual transformation of oil wealth into other forms of capital through the implementation of smooth medium-term expenditure programs and measures to increase non-oil revenue; and (ii) a well-designed fiscal framework that would help the government to reorient the budget formulation and implementation away from annual targets and more towards long-term fiscal goals, and guarantee an efficient and transparent budget execution.

Chapter $\mathrm{V}$ argues that civil service reform is essential for strengthening Chad 's public administrative capacity, with the view of improving policy formulation and implementation, and governance. However, largely owing to poor ownership and coordination and lack of financing, the quality of the civil service remains poor: public employment composition is not in line with the government's poverty reduction strategy and personnel management does not adequately support performance or safequard the quality of public service delivery. In addition, the wage bill absorbs a significant share of resources, which combined with Chad's weak financial management system, contributed to the frequent emergence of wage arrears.

Chapter VI examines the status and development challenges of Chad's microfinance sector. The paper concludes that the sector has helped improve the population's access to financial services. However, its expansion has been geographically uneven, the operations of microfinance institutions remain small, and their management and financial performance are weak. In addition, the microfinance sector's growth has created pressure for improved human resource and information technology systems. To ensure that the microfinance sector is a key ingredient of economic growth and poverty reduction, the sector's human resource and information technology systems need to be strengthened to promote more balanced - and sustainable - growth. 


\section{Sources OF ECONOMIC GROWTH IN CHAD ${ }^{1}$}

\section{A. Introduction}

1. This paper supplements the standard growth accounting exercise, which reveals historical sources of growth, with an analysis of Chad's current growth potential, including the opportunities the petroleum sector offers. The paper analyzes factors of production and constraints that influence economic growth in Chad.

\section{The main findings of the paper are that}

- $\quad$ Armed conflicts and political instability in Chad over the last 40 years have seriously deterred the accumulation of human and physical capital and prevented the building of institutions that are vital for economic development. As a result, the annual average growth rate of real GDP per capita was only 0.63 percent from 1964 through 2000.

- $\quad$ The contribution of physical capital to GDP growth during the 1970s and 1980s was smaller than that of other factors of production, but its role has since become more central. Growth in 2000-04 was mainly driven by capital-intensive investments in oil production.

- Given its institutional capacity constraints, public spending above Chad's absorptive capacity could waste resources and cause a real appreciation of the currency. It is advisable that Chad save some oil revenues until its absorptive capacity improves.

- To expand its growth potential, Chad needs to improve its infrastructure, human capital, institutions, and governance.

3. The next section summarizes the historical growth of the economy. Section $\mathrm{C}$ compares factors of production for Chad and peer group countries. Section D presents the results of a growth accounting exercise. Section E discusses conditions under which Chad could benefit from the newly developed oil sector and describes obstacles facing the economy. Section F draws conclusions.

\section{B. Background}

4. Growth in Chad can be considered in terms of five periods, each characterized by significant political and economic developments. From 1963 through 1974, under the leadership of President Tombalbaye, per capita output grew on average 3 percent annually. From 1975, when Tombalbaye was assassinated, until 1982, when N'Djamena was captured by Hissen Habre, conflicts were particularly disruptive; output per capita fell by an average of 5 percent a year. During Habre's regime (1983-1989), per capita GDP grew by an average of 4.2 percent a year despite continuous conflict between government forces and the

\footnotetext{
${ }^{1}$ Prepared by Teresa Dabán and Dmitriy Kovtun.
} 
opposition. After Idriss Deby, the current president, took control of Chad in 1990, though political stability improved, the government faced numerous rebellions until well into the 1990s. From 1990 through 1999, annual per capita output growth therefore stagnated, averaging 0.44 percent a year. The petroleum era in Chad began in 2000; since then annual per capita GDP growth has been averaging 8.9 percent.

Figure 1. Chad: Real GDP per capita growth

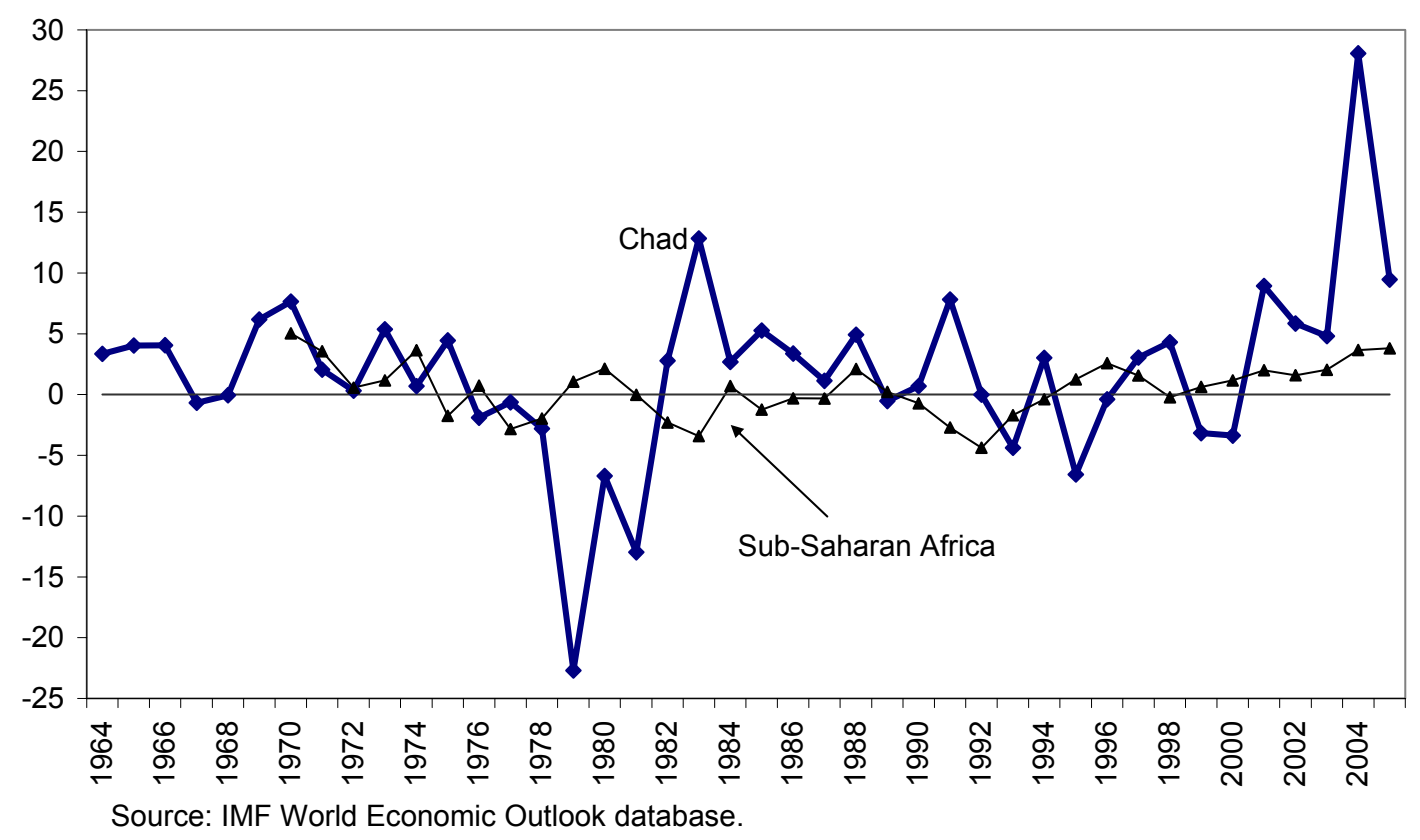

\section{Factors of Economic Growth in Chad and Peer Groups}

5. Factors that generally contribute to long-term economic growth are much weaker in Chad than in such peer groups as sub-Saharan countries generally, lowincome countries, HIPC countries, and least-developed countries. The components of long-term growth considered here are those identified by economic theory: (i) accumulation of physical capital; (ii) growth of human capital; and (iii) improvements in total factor productivity (TFP). TFP reflects not only the state of technology but also a wide range of other factors, such as the quality of institutions and governance, the business environment, macroeconomic stability, and other factors that affect the productivity of both capital and labor. 
Table 1. Classification of Countries

\begin{tabular}{|c|c|c|c|c|}
\hline \multirow{2}{*}{$\begin{array}{l}\text { Sub-Saharan Countries } \\
\text { ( } 48 \text { countries })\end{array}$} & \multicolumn{2}{|c|}{$\begin{array}{l}\text { Low Income Countries } \\
\text { (66 countries) }\end{array}$} & \multirow[t]{2}{*}{$\begin{array}{c}\text { HIPC } \\
\text { (35 countries) }\end{array}$} & \multirow{2}{*}{$\begin{array}{c}\text { Least Developed Countries } \\
\text { (UN classification) } \\
\text { (49 countries) }\end{array}$} \\
\hline & Afghanistan & Rwanda & & \\
\hline Benin & Angola & Saõ Tomé and Príncipe & Bolivia & Angola \\
\hline Botswana & Armenia & Senegal & Burkina Faso & Bangladesh \\
\hline Burkina Faso & Azerbaijan & Sierra Leone & Burundi & Benin \\
\hline Burundi & Bangladesh & Solomon Islands & Cameroon & Bhutan \\
\hline Cameroon & Benin & Somalia & Chad & Burkina Faso \\
\hline Cape Verde & Bhutan & Sudan & Cntrl, African Rep. & Burundi \\
\hline Cntrl. African Rep. & Burkina Faso & Tajikistan & Congo, Dem. Rep. of & Cambodia \\
\hline Chad & Burundi & Tanzania & Congo, Rep. of & Cape Verde \\
\hline Comoros & Cambodia & Timor-Leste & Côte d'Ivoire & Cntrl. African Rep. \\
\hline Congo, Dem. Rep. & Cameroon & Togo & Ethiopia & Chad \\
\hline Congo, Rep. of & Cntrl, African Rep. & Uganda & Gambia, The & Comoros \\
\hline Côte d'Ivoire & Chad & Ukraine & Ghana & Congo, Dem. Rep. \\
\hline Equatorial Guinea & Comoros & Uzbekistan & Guinea & Djibouti \\
\hline Eritrea & Congo, Dem. Rep. & Vietnam & Guinea-Bissau & Equatorial Guinea \\
\hline Ethiopia & Congo, Rep. of & Yemen, Rep. of & Guyana & Eritrea \\
\hline Gabon & Côte d'Ivoire & Zambia & Honduras & Ethiopia \\
\hline Gambia, The & Equatorial Guinea & Zimbabwe & Lao PDR & Gambia \\
\hline Ghana & Eritrea & & Madagascar & Guinea \\
\hline Guinea & Ethiopia & & Malawi & Guinea-Bissau \\
\hline Guinea-Bissau & Gambia, The & & Mali & Haiti \\
\hline Kenya & Georgia & & Mauritania & Kiribati \\
\hline Lesotho & Ghana & & Mozambique, Rep. of & Lao PDR \\
\hline Liberia & Guinea & & Myanmar & Lesotho \\
\hline Madagascar & Guinea-Bissau & & Nicaragua & Liberia \\
\hline Malawi & Haiti & & Niger & Madagascar \\
\hline Mali & India & & Rwanda & Malawi \\
\hline Mauritania & Indonesia & & São Tomé and Príncipe & Maldives \\
\hline Mauritius & Kenya & & Senegal & Mali \\
\hline Mayotte & Korea, Dem. Rep. & & Sierra Leone & Mauritania \\
\hline Mozambique & Kyrgyz Republic & & Sudan & Mozambique \\
\hline Namibia & Lao PDR & & Tanzania & Myanmar \\
\hline Niger & Lesotho & & Togo & Nepal \\
\hline Nigeria & Liberia & & Uganda & Niger \\
\hline Rwanda & Madagascar & & Zambia & Rwanda \\
\hline Saõ Tomé and Príncipe & Malawi & & & Samoa \\
\hline Senegal & Mali & & & Saõ Tomé and Príncipe \\
\hline Seychelles & Mauritania & & & Senegal \\
\hline Sierra Leone & Moldova & & & Sierra Leone \\
\hline Somalia & Mongolia & & & Solomon Islands \\
\hline South Africa & Mozambique & & & Somalia \\
\hline Sudan & Myanmar & & & Sudan \\
\hline Swaziland & Nepal & & & Togo \\
\hline Tanzania & Nicaragua & & & Tuvalu \\
\hline Togo & Niger & & & Uganda \\
\hline Uganda & Nigeria & & & Tanzania \\
\hline Zambia & Pakistan & & & Vanuatu \\
\hline Zimbabwe & Papua New Guinea & & & Yemen \\
\hline & & & & Zambia \\
\hline
\end{tabular}




\section{Human and physical capital}

6. Indicators of human capital, broadly defined as human abilities and health, are lower in Chad than in peer countries. The length of time an average person in Chad is schooled is shorter than that of an average person in any of the peer groups (Table 2), and the gender difference in length of schooling is strikingly higher than in the peer groups. Inadequate education decreases labor quality and increases the costs of doing business, most obviously for onsite training. Human capital in Chad is also constrained by generally poor health. Chad spends barely a third as much on health as the average sub-Saharan country.

Table 2. Indicators of Human Capital in Chad

\begin{tabular}{|c|c|c|c|c|c|}
\hline & $\begin{array}{c}\text { School Life } \\
\text { Expectanc } \\
\text { y } \\
\text { Both } \\
\text { Sexes, } \\
1998-2002 \\
\end{array}$ & $\begin{array}{c}\text { School Life } \\
\text { Expectanc } \\
\text { y } \\
\text { Female } \\
\text { 1998-2002 }\end{array}$ & $\begin{array}{c}\text { School Life } \\
\text { Expectanc } \\
y \\
\text { Male } \\
\text { 1998-2002 }\end{array}$ & $\begin{array}{c}\text { Health } \\
\text { Expenditur } \\
\text { e, } \\
1998- \\
2003^{1}\end{array}$ & $\begin{array}{c}\text { Life } \\
\text { Expectanc } \\
\text { y at Birth, } \\
\text { (years) } \\
2004\end{array}$ \\
\hline Chad & 5.41 & 3.87 & 6.88 & 12.8 & 43.9 \\
\hline Sub-Saharan Africa & 7.25 & 6.66 & 7.67 & 31.4 & 46.2 \\
\hline Low-income countries & 6.67 & 5.96 & 6.93 & 25.4 & 58.7 \\
\hline HIPC countries & 6.64 & 6.05 & 7.14 & 39.3 & 49.3 \\
\hline $\begin{array}{l}\text { Least-developed } \\
\text { countries }\end{array}$ & 6.29 & 5.68 & 6.79 & 31.5 & 52.1 \\
\hline
\end{tabular}

Sources: UNESCO Institute for Statistics (http://stats.uis.unesco.org/TableViewer/); World Bank, World Development Indicators 2006 database.

${ }^{1}$ Annual per capita expenditure in current US dollars.

7. As the growth research literature would suggest, Chad's human capital inadequacies undermine its long-term growth prospects. Because human capital is considered one of the most important determinants of economic growth, countries with richer human capital resources are seen to be better positioned for economic growth. Lucas (1993) argues that human capital plays a more important role for long-term economic growth than accumulation of physical capital. Barro (2001) finds that growth is positively related to average secondary and higher education attainment of adult males. Baldacci et al. (2004) demonstrate that the impact of education and health on growth is especially pronounced in low-income countries. They estimate that an increase of 1 percentage point in the composite enrollment rate is associated with an 0.1 percentage point increase in per capita GDP growth. Similarly, a 1 percentage point increase in the survival rate of children under 5 is associated with an 0.1 percentage point increase in per capita GDP growth. Since it is virtually impossible to improve human capital in the short run, the dearth of human capital is one of the most limiting constraints on long-term growth in Chad.

8. The indicators and anecdotal evidence suggest that capital stock per worker in Chad is much lower than in peer groups (Table 3 ). The agricultural sector provides a striking illustration of the paucity of capital in the economy: farmers not only lack agricultural machinery, they lack plows, leaving them with only the most primitive means of 
production. Roads are poor and largely unusable during the rainy season. Cotton farmers report that the poor quality of roads raises their production costs due to the substantial losses incurred during transportation.

Table 3. Indicators of Capital Stock and Infrastructure in Chad

\begin{tabular}{lccc}
\hline & $\begin{array}{c}\text { Tractors per 100 } \\
\text { Hectares of Arable } \\
\text { Land } \\
2003\end{array}$ & $\begin{array}{c}\text { Paved Roads (percent } \\
\text { of total roads) } \\
1999\end{array}$ & $\begin{array}{c}\text { Gross Capital } \\
\text { Formation } \\
\text { (percent of GDP) } \\
1990-2000\end{array}$ \\
\hline Chad & 0.005 & 0.8 & 13.0 \\
Sub-Saharan Africa & 0.13 & 12.5 & 16.9 \\
Low-income countries & 0.89 & 13.3 & 22.6 \\
HIPC countries & 0.07 & 12.1 & 17.8 \\
Least-developed countries & 0.07 & 13.3 & 18.0 \\
\hline Source: World Bank, World Development Indicators 2006 database.
\end{tabular}

9. The scarcity of human and physical capital reduces labor productivity. The dominant share of the labor force is employed in the low-productivity agricultural sector. ${ }^{2}$ The formal economy is still nascent, consisting only of a service sector located primarily in N'Djamena and an insignificant manufacturing sector. Because it is capital intensive, the emerging petroleum sector has not had much impact on employment.

\section{Institutions and governance}

10. Governance is much poorer in Chad than in peer countries. Kaufmann et al. (2003) studied the quality of governance in a broad sample of countries. Defining governance as the traditions and institutions by which authority in a country is exercised, they rank the countries in their sample according to six measures of governance: (i) voice and accountability; (ii) political stability and lack of violence; (iii) government effectiveness; (iv) regulatory quality; (v) rule of law; and (vi) control of corruption. Higher values correspond to better governance outcomes. The indicators reveal a troubling picture: except for government effectiveness, Chad is in only the 20th to 40th percentile. What is worrisome is that its performance on all indicators except the rule of law deteriorated between 1996 and 2002 (Table 4). The corruption index published in 2006 by Transparency International labels Chad and Bangladesh among the most corrupt countries in the world.

\footnotetext{
${ }^{2}$ According to the World Bank's World Development Indicators database, the share of agriculture workers in the labor force was 83 percent in 1990, which is the only data point for Chad.
} 
Table 4. Aggregate Governance Indicators in Chad and Peer Group Countries, 1996-2002

\begin{tabular}{|c|c|c|c|c|c|c|c|c|c|c|}
\hline & & & \multicolumn{2}{|c|}{$\begin{array}{c}\text { Sub-Saharan } \\
\text { Countries }\end{array}$} & \multicolumn{2}{|c|}{$\begin{array}{c}\text { Low-Income } \\
\text { Countries }\end{array}$} & \multicolumn{2}{|c|}{$\begin{array}{c}\text { Least-Developed } \\
\text { Countries }\end{array}$} & \multicolumn{2}{|c|}{$\begin{array}{c}\text { HIPC } \\
\text { Countries }\end{array}$} \\
\hline & & $\begin{array}{l}\text { Chad } \\
\text { Index }\end{array}$ & $\begin{array}{l}\text { Group } \\
\text { Average }\end{array}$ & $\begin{array}{l}\text { Chad's } \\
\text { Percentile }\end{array}$ & $\begin{array}{l}\text { Group } \\
\text { Average }\end{array}$ & $\begin{array}{l}\text { Chad's } \\
\text { Percentile }\end{array}$ & $\begin{array}{l}\text { Group } \\
\text { Average }\end{array}$ & $\begin{array}{l}\text { Chad's } \\
\text { Percentile }\end{array}$ & $\begin{array}{l}\text { Group } \\
\text { Average }\end{array}$ & $\begin{array}{l}\text { Chad's } \\
\text { Percentile }\end{array}$ \\
\hline & 2002 & -0.95 & -0.64 & 0.40 & -0.78 & 0.43 & -0.63 & 0.36 & -0.67 & 0.38 \\
\hline & 2000 & -0.89 & -0.58 & 0.44 & -0.73 & 0.44 & -0.58 & 0.40 & -0.62 & 0.44 \\
\hline Voice and & 1998 & -0.83 & -0.52 & 0.40 & -0.69 & 0.44 & -0.52 & 0.43 & -0.58 & 0.38 \\
\hline \multirow[t]{3}{*}{ Accountability } & 1996 & -0.72 & -0.50 & 0.40 & -0.65 & 0.47 & -0.48 & 0.45 & -0.53 & 0.41 \\
\hline & 2002 & -1.78 & -0.55 & 0.16 & -0.73 & 0.14 & -0.59 & 0.16 & -0.58 & 0.15 \\
\hline & 2000 & -0.80 & -0.64 & 0.43 & -0.71 & 0.43 & -0.71 & 0.44 & -0.59 & 0.33 \\
\hline Political & 1998 & -1.36 & -0.60 & 0.20 & -0.62 & 0.23 & -0.66 & 0.28 & -0.51 & 0.15 \\
\hline \multirow[t]{3}{*}{ Stability } & 1996 & -0.69 & -0.46 & 0.33 & -0.49 & 0.33 & -0.50 & 0.36 & -0.41 & 0.27 \\
\hline & 2002 & -0.75 & -0.71 & 0.53 & -0.82 & 0.60 & -0.76 & 0.54 & -0.77 & 0.53 \\
\hline & 2000 & -0.21 & -0.64 & 0.67 & -0.75 & 0.80 & -0.65 & 0.70 & -0.60 & 0.71 \\
\hline Government & 1998 & -0.33 & -0.57 & 0.60 & -0.65 & 0.70 & -0.58 & 0.67 & -0.48 & 0.59 \\
\hline \multirow[t]{3}{*}{ Effectiveness } & 1996 & -0.69 & -0.62 & 0.47 & -0.66 & 0.44 & -0.68 & 0.47 & -0.63 & 0.50 \\
\hline & 2002 & -1.11 & -0.65 & 0.24 & -0.82 & 0.29 & -0.79 & 0.28 & -0.67 & 0.18 \\
\hline & 2000 & -0.28 & -0.47 & 0.44 & -0.64 & 0.63 & -0.58 & 0.54 & -0.32 & 0.35 \\
\hline Regulatory & 1998 & -0.67 & -0.51 & 0.31 & -0.62 & 0.38 & -0.64 & 0.40 & -0.37 & 0.26 \\
\hline \multirow[t]{4}{*}{ Quality } & 1996 & -0.04 & -0.57 & 0.76 & -0.67 & 0.86 & -0.60 & 0.82 & -0.45 & 0.76 \\
\hline & 2002 & -0.93 & -0.67 & 0.36 & -0.84 & 0.40 & -0.72 & 0.30 & -0.75 & 0.29 \\
\hline & 2000 & -0.82 & -0.60 & 0.36 & -0.79 & 0.45 & -0.75 & 0.37 & -0.70 & 0.35 \\
\hline & 1998 & -0.98 & -0.62 & 0.29 & -0.76 & 0.31 & -0.74 & 0.28 & -0.69 & 0.24 \\
\hline \multirow[t]{2}{*}{ Rule of Law } & 1996 & -0.18 & -0.56 & 0.66 & -0.72 & 0.83 & -0.76 & 0.78 & -0.67 & 0.76 \\
\hline & 2002 & -1.02 & -0.59 & 0.22 & -0.79 & 0.32 & -0.68 & 0.22 & -0.71 & 0.18 \\
\hline \multirow{2}{*}{$\begin{array}{l}\text { Control of } \\
\text { Corruption }\end{array}$} & 2000 & -0.61 & -0.53 & 0.51 & -0.73 & 0.67 & -0.61 & 0.50 & -0.65 & 0.59 \\
\hline & 1998 & -0.84 & -0.57 & 0.22 & -0.69 & 0.29 & -0.64 & 0.18 & -0.66 & 0.15 \\
\hline
\end{tabular}

Source: D. Kaufmann, A. Kraay, M. Mastruzzi: Governance Indicators for 1996-2002.

World Bank Institute, http://www.worldbank.org/wbi/governance/govdata2002/index.html.

11. Poor governance is another major barrier to Chad's achieving high growth. The quality of a country's institutions and governance has been found to be the most significant determinant of long-term development (Acemoglu and others, 2004). Besides having a direct effect on growth, institutions and governance have an important indirect effect through human capital and investment. Baldacci and others (2004) found that poor governance greatly diminishes the efficiency of social spending: countries with better than average governance grow 1.6 percentage points faster than those with worse than average governance. Given the tremendous importance of institutions for the efficiency of social spending, the overarching challenge facing Chadian authorities is how to increase the quality of their institutions and to fight corruption.

\section{Growth Accounting Exercise}

\section{Methodology}

12. This section presents the results of a growth accounting exercise to determine the relative contributions of factors of production to output growth in Chad for the period 
1969-2004. Though Bosworth and Collins (2003) believe that such an exercise does not reveal the true causes of growth, they agree that it gives a helpful indication of its components and is therefore useful for examining data. In the case of Chad, about which the data are unreliable, the results should in any case be considered with the greatest caution.

\section{As in other growth accounting studies, a Cobb-Douglas production function with} the constant returns to scale is here assumed for Chad:

$$
Y_{t}=A_{t} K_{t}^{\alpha} L_{t}^{1-\alpha}
$$

where $Y_{t}$ is total output, $K_{t}$ is the stock of physical capital, and $L_{t}$ is labor during period $t$. $A_{t}$ is TFP, representing the level of technology, and $\alpha$ is the capital share in output. The capital share is assumed to be equal to 0.35 , as in other studies on African countries. The production function (1) can be represented in a growth form as follows:

$g y_{t}=g a_{t}+\alpha \cdot g k_{t}+(1-\alpha) \cdot g l_{t}$,

where $g y_{t}$ is the growth rate of output, $g a_{t}$ is the growth rate of TFP, and $g k_{t}$ and $g l_{t}$ are the growth rates of capital and labor inputs.

\section{Data}

14. Because estimates of the capital stock in Chad are not available, they must be drawn from data on investment. Following Bosworth and Collins (2003), we use the perpetual inventory model to estimate Chad's capital stock. The fixed capital is assumed to evolve according to the following law:

$$
K_{t}=K_{t-1}\left(1-d_{t}\right)+I_{t}
$$

where $d_{t}$ is the depreciation rate and $I_{t}$ is gross fixed investment. Also, like Bosworth and Collins, we assume that the capital stock-to-GDP ratio equals 1.5 in the first year, and the annual rate of depreciation is 5 percent. To account for the destruction of the capital stock during years when fighting was especially disruptive, the annual depreciation rate is assumed to be 10 percent from 1979 through 1982. As a robustness check, the growth accounting exercise is repeated with a 10 percent depreciation rate (except for 1979-82, where it is assumed to be 15 percent).

15. Because estimates of human capital are not available, it is impossible to account for how investment in developing human capital would affect output. Thus, improvements in the quality of labor are attributed to TFP rather than to the productivity of human resources. In the calculations that follow, labor input is proxied by the size of the labor force, which is obtained from the World Development Indicators database. 


\section{Results}

16. Physical capital played a relatively minor role in output growth from $\mathbf{1 9 6 9}$ through 1974. During this period, growth was explained mainly by TFP, which contributed more than two-thirds of the total annual growth of 5.8 percent (Table 5). It must be noted, however, that TFP captures not only improvements in technology but also all other factors that influence economic growth. Notably, growth in agriculture due to favorable weather conditions can stimulate TFP, creating the appearance of an increase in technology.

Table 5. Sources of Economic Growth in Chad, 1969-2004 ${ }^{1}$

\begin{tabular}{|c|c|c|c|c|c|}
\hline & $1969-74$ & $1975-82$ & 1983-89 & $1990-99$ & 2000-04 \\
\hline Real GDP growth, percent & 5.82 & -3.12 & 6.85 & 3.27 & 13.05 \\
\hline $\begin{array}{l}\text { Contribution of capital input, } \\
\text { percentage points }\end{array}$ & 0.74 & -0.35 & 1.32 & 1.86 & 6.64 \\
\hline $\begin{array}{l}\text { Contribution of labor input, } \\
\text { percentage points } \\
\text { Contribution of total factor }\end{array}$ & 1.08 & 1.26 & 1.60 & 1.78 & 1.79 \\
\hline productivity, percentage points & 4.00 & -4.02 & 3.92 & -0.37 & 4.63 \\
\hline
\end{tabular}

17. For 1975-82, data on the relation of constituent factors to real GDP growth are very unreliable because of the civil war. If, as is possible, the capital stock decreased by much more than the assumed rate of depreciation, a larger share of the decline in growth could be attributed to its loss. Given present assumptions, the negative growth is associated mainly with the destruction of capital and deterioration in TFP.

18. Contributing factors are mixed for 1983-89. Decomposition of real GDP growth reveals similar contributions of labor and capital inputs and a large increase in TFP. The rise in TFP is probably explained by the end of the civil war.

19. In 1990-99 and 2000-04, the contribution of physical capital to output growth increased. Calculations for 1990-99 suggest that GDP growth then was driven by the accumulation of the factors of production, with the contribution of TFP being negative. This could be explained by the loss of human capital from the large-scale emigration of educated Chadians to Cameroon. Finally, growth in 2000-04 was driven by the accumulation of capital stock related to construction of the oil pipeline.

20. Increasing the assumed rate of depreciation of physical capital changes the contributions of capital and TFP, but qualitatively the results remain the same (Table 6). It is plausible that the annual rate of depreciation of physical capital in Chad is more than 5 percent. Table 6 presents the decomposition of real GDP growth assuming that physical capital depreciates 10 percent annually (15 percent during the years of fighting). For 1975-82, the loss of growth associated with the loss of capital becomes more pronounced, but the contribution of TFP is still negative. 
Table 6. Decomposition of GDP Growth Assuming a High Depreciation Rate

\begin{tabular}{|c|c|c|c|c|c|}
\hline & $1969-74$ & $1975-82$ & $1983-89$ & $1990-99$ & 2000-04 \\
\hline Real GDP growth, percent & 582 & $-3,12$ & 685 & 327 & 1305 \\
\hline $\begin{array}{l}\text { Contribution of capital input, } \\
\text { percentage points } \\
\text { Contribution of labor input }\end{array}$ & -0.69 & -1.22 & 1.40 & 2.00 & 8.04 \\
\hline $\begin{array}{l}\text { Contribution of labor input, } \\
\text { percentage points } \\
\text { Contribution of total factor }\end{array}$ & 1.08 & 1.26 & 1.60 & 1.78 & 1.79 \\
\hline productivity, percentage points & 5.43 & -3.15 & 3.84 & -0.51 & 3.23 \\
\hline
\end{tabular}

21. With completion of the Chad-Cameroon pipeline in 2003, the petroleum era began in Chad, bringing hopes for rapid economic development. However, there is ample evidence from other African countries that using petroleum resources to create sustainable economic growth is not easy. The next section discusses whether the new-born petroleum sector will be able to accelerate economic development and long-run growth in Chad.

\section{E. Will the Oil Sector Help Boost Chad's Growth?}

22. The petroleum sector affects the economy of Chad through (i) a direct channel related to exploration and oil extraction; and (ii) an indirect channel related to government spending of oil revenues. The direct channel has both first-order effects associated with the value added by exploration, field development, and sale of oil and second-order effects resulting from the growth of local activities to satisfy the oil sector's demand for inputs (e.g., catering, basic services). The indirect channel has such first-order effects as the additional value added created by government contractors and second-order multiplier effects resulting from an increase in household purchasing power.

23. According to current estimates, the direct channel is giving significant impetus to overall GDP growth, though that will decrease in coming years. Driven by pipeline construction and the initiation of oil production in 2003, real GDP growth averaged 11 percent in 2001-03. In 2004, the first full year of oil production, real GDP grew by a record 30 percent. Though there was a recovery in agriculture activities after the 2004 drought, the 12.2 percent GDP growth in 2005 reflected the fact that growth in the oil sector was significantly lower than projected because much more water was found in the wells than was expected. ${ }^{3}$ The recent period of rapid growth is expected to end in 2006 as oil production trends downward.

\footnotetext{
${ }^{3}$ Initial projections were for oil production to remain at 225,000 barrels per day (bpd) during 2005-09 and to decrease gradually to 150,000 bdp by 2010 and further to 100,000 after 2014 . Actual daily oil production in 2005 was about $173,000 \mathrm{bpd}$, in spite of the application of reinjection techniques to increase the yield of the
} 
24. Given the "enclave" nature of the petroleum sector within Chad, its impact on the domestic economy is limited. Oil company activities in countries like Chad are highly localized and of limited size. In Chad, the only links between the local and the petroleum economies are (i) oil company employment and training of a small number of local workers; (ii) oil company development activities; and (iii) government spending of oil revenues. Since the petroleum sector is capital-intensive, its impact on domestic employment is negligible. For example, Esso was employing only 1,376 local people at the end of $2004{ }^{4}$ That is why gross national product (GNP) is a much better measure of economic activity than GDP. Because GDP includes the value added by the consortium, which repatriates a significant share of value added in the oil sector as profits and loan repayments, it grossly overstates the activity of the Chadian economy. In 2003, for example, the growth rate of real GDP was 15 percent - but GNP is estimated to have decreased by about 2 percent.

25. Spending of the oil revenues is therefore the only channel that can have a sizeable impact on the local economy. Using oil revenues to upgrade infrastructure and invest in human and physical capital will be vital for relaxing the severe constraints already discussed. For example, improving transportation and providing more stable electrical and other utilities by decreasing system-wide unit costs may boost productive capacity. However, a key issue here is how much new spending the economy can absorb without generating inflationary pressures and the symptoms of Dutch disease. This issue is discussed below.

26. The effect of oil-financed government spending on aggregate activity would depend on the supply response of the economy. Spending oil revenues on inelastically supplied inputs will raise their prices, crowding them out from the private sector. The effect of spending on aggregate activity will be largest if the economy can channel idle resources (such as the unemployed) into productive uses, in which case an increase in aggregate demand generated by additional government spending would be met by a corresponding increase in aggregate supply. In this favorable scenario, the total effect of government spending on aggregate income would consist of not only first-order effects (the income government contractors receive for projects financed by oil revenue inflows) but also secondorder effects resulting from increased household purchasing power because of higher employment. This higher purchasing power could also help deepen markets and expand the production of existing firms, thereby decreasing their unit costs. ${ }^{5} \mathrm{~A}$ system-wide decrease in unit costs could lead to improved productivity generally, enhancing growth potential.

27. It is likely, however, that Chad's domestic supply would be slow to respond to oil revenue spending. First, the supply of skilled labor is inelastic. Although there is ample unemployment, there is a severe shortage of skilled labor. It is also very difficult to create

wells and the coming on line of new oil fields. For the period 2006-09, daily oil production is projected at $135,000 \mathrm{bpd}$.

${ }^{4}$ Source: Chad Export Project Report \#17, ESSO, 2004 http://www.essochad.com/Chad/Files/Chad/17_allchapters.pdf

${ }^{5}$ Building a local brewery in expectation of higher household incomes would be an example of business creation. 
new businesses because the business environment is unfavorable: In 2005, entrepreneurs in Chad had to go through 19 steps to launch a business, taking an average of 75 days, at a cost equal to 360.8 percent of per capita gross national income (GNI). ${ }^{6}$ To obtain a business registration number they had to deposit at least 619.1 percent of per capita GNI in a bankmore than twice the regional average of 297.2 percent and fifteen times the OECD average of 41.0 percent. Improving regulation to enhance the business environment would be one excellent way to remove constraints on aggregate supply.

28. Owing to bottlenecks in domestic supply, oil revenue inflows could negatively affect the competitiveness of the economy and severely undermine macroeconomic stability. Given supply constraints, a substantial increase in oil revenue spending could speed up inflation, which would put upward pressure on the real exchange rate and reduce the competitiveness of the non-oil tradable sector. ${ }^{7}$ And given that a large part of the Chadian population is employed in the cotton sector (the largest export sector after oil), a further decline in its competitiveness could result in either an unreasonably large budget cost to support cotton farmers or grave social consequences if the cotton sector were to shrink, with a concomitant loss in employment.

29. Structural reforms to increase the competitiveness of the economy are necessary to counteract negative pressures on the real effective exchange rate. Improving the factors of production (see Section C) would expand the production potential of the economy. Chad could definitely benefit from investing in such vital areas as infrastructure, the energy sector, education, and health that would allow for system-wide increases in economic efficiency. The need to save part of the oil revenues principally arises because the successful development and implementation of investment projects is not a trivial task. To avoid waste, too, spending of oil revenues should be consistent with the absorptive capacity of the economy.

\section{F. Conclusions and Recommendations}

30. Chad's current growth potential is seriously limited by low levels of both human and physical capital and by weak institutions and governance. Chad's indicators of human and physical capital are below those of peer countries. Chad also ranks at the bottom of various measures of governance and cost of doing business.

\section{The development of the petroleum sector in Chad will not automatically} translate into faster development and sustainable economic growth. The direct impact of the petroleum sector is limited because the sector is not well integrated into the local economy. Moreover, the impact of oil-financed government spending on aggregate activity is likely to be limited by the rigidities of the supply side of Chad's economy. This in turn could lead to increasing inflation and erosion of the economy's competitiveness.

\footnotetext{
${ }^{6}$ The data are taken from the World Bank Doing Business database, which collects data on (i) procedures required to establish a business, (ii) the associated time and cost, and (iii) the minimum capital requirement.

${ }^{7}$ See Chapter III on the competitiveness of the non-oil sector in Chad.
} 
32. If the economy is to expand without macroeconomic destabilization, oil-financed spending programs must be accompanied by prudent macroeconomic policies and structural measures to improve the absorptive capacity of the economy. To prevent a loss of competitiveness in the tradable sector, Chad needs to upgrade its infrastructure and physical capital, make plans to develop human capital, and create a business environment that would allow an appropriate supply-side response to government spending. To increase the efficiency and effectiveness of social spending, the Chadian authorities would also need to upgrade substantially the quality of public institutions and governance generally. 


\section{References}

Acemoglu, Daron, Simon Johnson, and James Robinson, "Institutions as the Fundamental Cause of Long-Run Growth," in Handbook of Economic Growth, edited by P. Aghion and S. Durlauf. Amsterdam; Boston: Elsevier: North-Holland, 2005.

Akitoby, Bernardin, and Matthias Cinyabuguma, 2004, "Sources of Growth in the Democratic Republic of the Congo: A Cointegration Approach," IMF Working Paper 04/114 (Washington: International Monetary Fund).

Baldacci, Emanuele, Benedict Clements, Sanjeev Gupta, and Qiang Cui, 2004, "Social Spending, Human Capital, and Growth in Developing Countries: Implications for Achieving the MDGs," IMF Working Paper 04/217 (Washington: International Monetary Fund).

Barro, R.J., 2001, "Human Capital and Growth," American Economic Review, Vol. 91 (2): pp. 12-17.

Bosworth, Barry P., and Susan Collins, 2003, "The Empirics of Growth: An Update," Brookings Papers on Economic Activity, Vol. 2, pp. 113-206.

Encyclopædia Britannica, 2003, from Encyclopcedia Britannica Ultimate Reference Suite 2004 CD-ROM. Copyright (C) 1994-2003 Encyclopædia Britannica, Inc.

Economist Intelligence Unit, 2003, "Chad: Country Profile 2003”, from www.eiu.com.

International Monetary Fund, 2006, World Economic Outlook Database (Washington: International Monetary Fund)..

Nsengiyumva, Fabien, 2004, "Sources of Economic Growth in Benin," in Benin: Selected Issues and Statistical Appendix (Washington: International Monetary Fund).

Kaufmann, Daniel, Aart Kraay, and Massimo Mastruzzi, 2003, "Governance Matters III: Governance Indicators for 1996-2002,” Policy Research Department Working Paper (Washington: World Bank).

Lucas, Robert E., 1993, “Making a Miracle,” Econometrica, Vol. 61(2), pp. 251-72.

Transparency International, 2005, Corruption Perceptions Index 2005, from http://www.transparency.org/.

World Bank, 2005, Doing Business Database (Washington: World Bank). , 2005, World Development Indicators Database. (Washington: World Bank) ,2005, "World Development Report 2005: A Better Investment Climate for Everyone" (Washington: World Bank). 


\section{Chad: Dimensions of Poverty and Distribution of Oil Revenue ${ }^{8}$}

\section{A. Introduction}

1. The coming on-stream of oil revenue in $\mathbf{2 0 0 4}$ has given Chad an unprecedented opportunity to make a lasting dent in poverty. To seize this opportunity, the authorities must implement well-designed policies to avoid the "natural resource curse." This paper describes the main features of poverty in Chad and assesses alternative ways of using oil revenue to reduce poverty over time.

2. The main findings of the paper are as follows:

- Despite its strategic location for trans-African trade and recent oil production, Chad remains one of the least developed countries in the world. Almost twothirds of the population earns less than one U.S. dollar per day, and human development and living standard indicators are well below the averages for subSaharan Africa.

- Poverty in Chad has complex economic and social dimensions. Food scarcity, the rural population's vulnerability to climatic disturbances and natural disasters, lack of employment opportunities, and poor access to health care, education, and basic infrastructure all contribute to the country's high poverty level.

- The allocation of newfound oil resources to reduce poverty over time needs to be adjusted to Chad's level of development and preferences. Given Chad's limited economic development, there are strong arguments for spending a large part of the oil revenue rapidly - if macroeconomic and institutional absorptive capacity can be improved - through the implementation of appropriate public sector programs.

- The implementation of a well-prepared Medium Term Expenditure Framework (MTEF) would help Chadian authorities use oil revenues to support poverty reduction. While ensuring fiscal sustainability, MTEF measures to improve infrastructure, access to credit, institutional environment and governance, human capital, and absorptive capacity would reinforce non-oil sector productivity.

3. This paper is organized as follows. Section B presents background information. Section $\mathrm{C}$ describes the dimensions of poverty in Chad. Section D discusses potential strategies to reduce poverty using oil revenue. Section E presents conclusions and recommendations.

\footnotetext{
${ }^{8}$ Prepared by Tove Strauss.

${ }^{9}$ In many resource-based economies, lackluster economic development typically reflects increased rent-seeking behavior, an appreciated domestic currency, and volatile revenue performance (Hausmann and Rigobon, 2003).
} 


\section{B. Background}

4. As Chad only recently began producing petroleum, the economy is still largely agricultural and pastoral. About 80 percent of the landlocked country's population of 8.6 million live in rural areas and make their living from agriculture and animal husbandry. Approximately half the population resides in the southern belt, comprising about a fifth of the country's territory and containing most of Chad's major cities. Most other people live in the central belt (Sahelian zone), and only about 100,000 pastoralists live in the northern Saharan region. In the south, cotton is the principal cash crop, employing about 300,000 families, and investment in industry (including the new petroleum industry) is relatively high. Apart from the petroleum sector, Chad's industries include the processing of cotton, meat products, and salt and the production of bottled beer, soap, cigarettes, construction materials, and cereal (though the production of cereals mostly supports domestic consumption). The country struggles with high underemployment, and the underdeveloped micro-credit system is available only to middle- and upper-income groups.

5. With the start of oil production, real GDP growth reached close to 30 percent in 2004 and 12 percent in 2005. After hovering around US\$240 in 1994-2003, Chad's real per capita GDP reached US\$315 in 2004 and US\$326 in 2005, boosted by the start of oil production and the expected stream of 1 billion barrels of crude oil over the next 25 to 30 years. Real non-oil GDP per capita, however, stayed fairly constant, reaching US\$238 in 2004 and US\$226 in 2005 (Figure V.1). The new oil fields have not provided significant work opportunities for unskilled laborers. Given the projected decline in oil production, further increases in Chad's GDP will depend on non-oil sector growth and continued inflows of external support.

6. Chad ranks very low on most nonmonetary poverty indicators. According to the 2005 United Nations Development Program (UNDP) Human Development Report, Chad ranks 173 out of 177 countries (Figure 2). ${ }^{10}$ Chad also has a very high under-five mortality rate, ranking number 12 out of 192 countries on UNICEF's index of such mortality rates. ${ }^{11}$ Chad also performs poorly against other nonmonetary measures of poverty. Indeed, access to basic services, such as health care, sanitation, sewage, electricity, and transportation, is severely lacking, especially in rural areas.

\footnotetext{
${ }^{10}$ The Human Development Index (HDI) ranges from 0 to 1 and measures achievements in terms of life expectancy, educational attainment, and adjusted real income.

${ }^{11}$ A high ranking signifies a relatively high under-five mortality rate.
} 


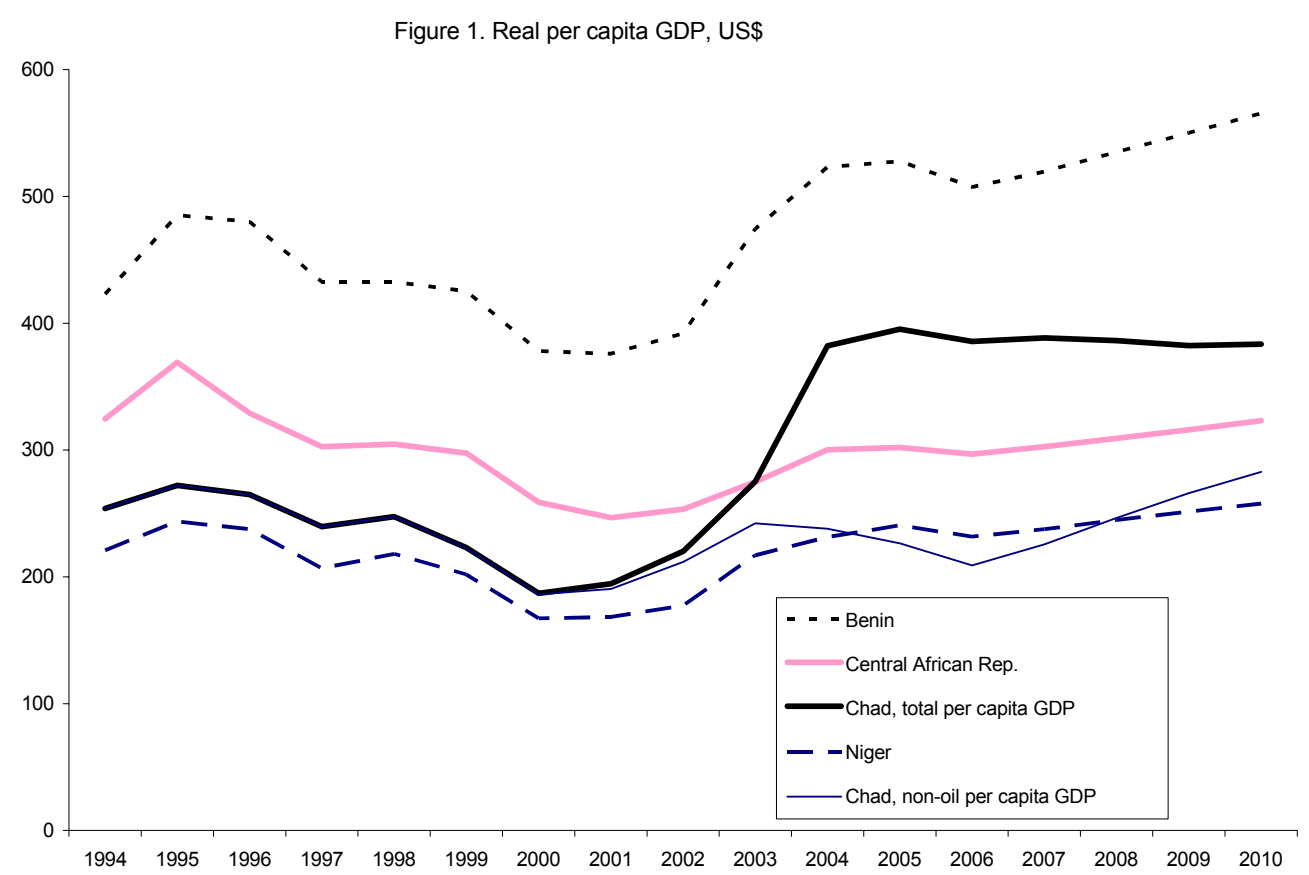

Source: World Economic Outlook, IMF and IMF staff projections.

Figure 2. Sub-Saharan Africa: Human development index (HDI)

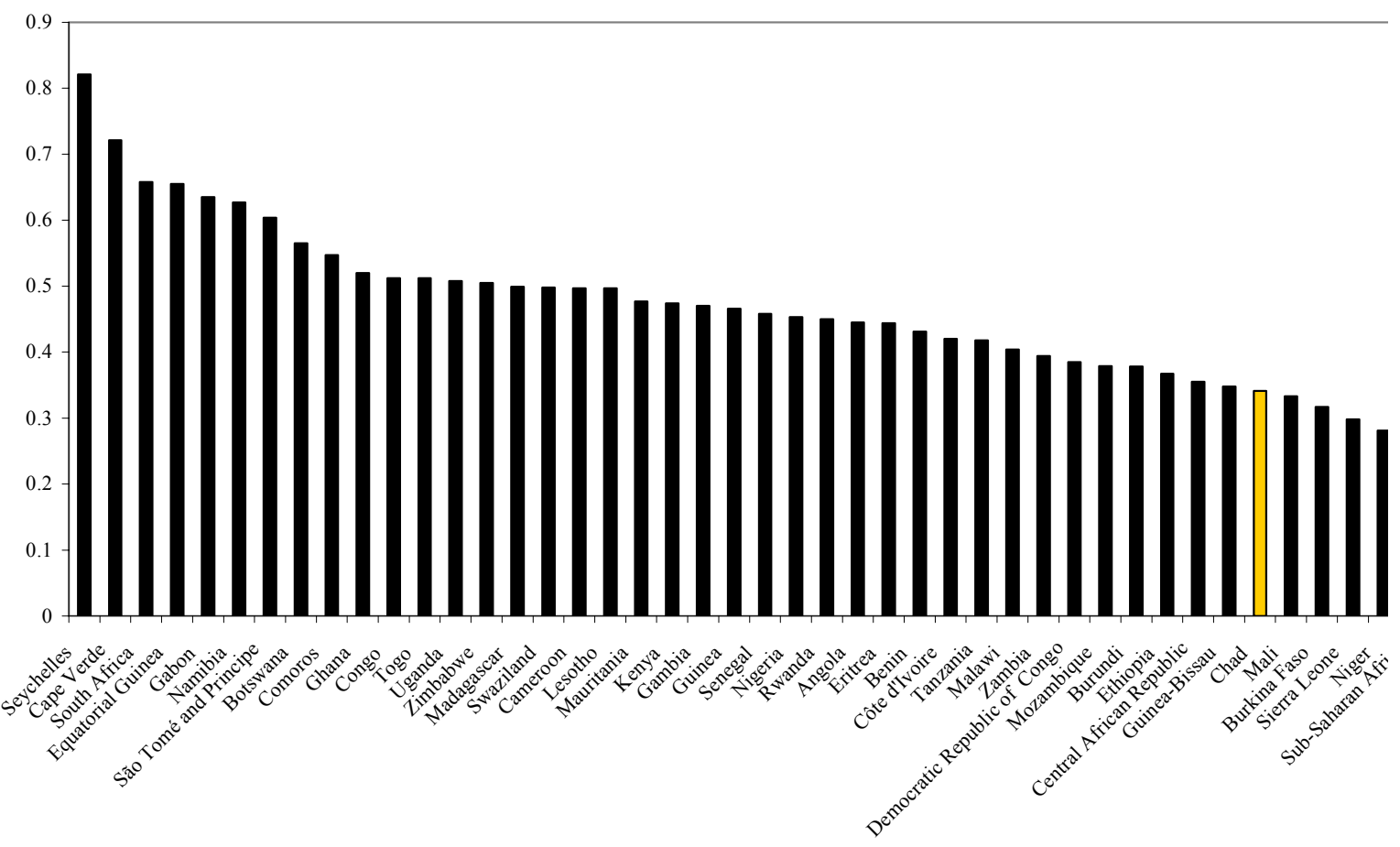

Source: UNDP, 2005 Human Development Report. 
7. In addition to contending with extreme domestic poverty, Chad has had to cope with large refugee inflows from neighboring countries. Besides impacting government spending, refugee inflows also tend to have a negative economic impact on the poor pastoral populations living near refugee camps. And though some internal migration brings additional income to the rural poor, Chad does not have significant emigration and limited remittances from abroad benefit the poor.

\section{Dimensions of Poverty in Chad}

\section{Measuring the poverty line}

8. Owing to a lack of reliable data, it is difficult to assess Chad's poverty situation and trends. The latest available household consumption survey, ECOSIT I, was conducted in 1995-96. ${ }^{12}$ The analytical results of a new household survey taken in 2003 are not yet available. There are no data on Chad's Gini coefficient or its unemployment rate.

9. According to the latest information available, almost two-thirds of the Chadian population is poor i.e. they live below the national poverty line (Table 1). The national poverty line defined by ECOSIT I is significantly lower. This poverty line, which conveys the proportion of households with daily spending below the level needed to meet minimal food and nonfood needs, varies by region. The daily level at the time of the study was estimated at an average of CFAF 253 - slightly more than one-third of a U.S. dollar. By this definition, 43 percent of the Chadian population was poor in 1995-96.

10. The highest poverty rates are in rural areas, where about four-fifths of the population resides. Rural areas also lag urban areas on most other measures of poverty. Access to education, health care, sanitation, and electricity are well below urban levels. The poverty rate in N'Djamena is an estimated 35 percent.

\section{Food security and basic needs ${ }^{13}$}

11. The rural population mainly lives on subsistence farming, fishing, and livestock herding. The country's vulnerability to climatic disturbances and natural disasters, including droughts, floods, and locust invasions, make it subject to food shortages. In the arable south, roughly one of every three years is poor. Even though Chad has not experienced a major food crisis in recent years, serious food insecurity continues in certain areas, particularly in the

\footnotetext{
${ }^{12}$ The ECOSIT I collected data only in Chad's four major cities and some of these cities' surrounding. ECOSIT II, a more comprehensive study expected to be available later this year, will inform the revision of the Poverty Reduction Strategy Paper.

${ }^{13}$ This subsection draws on information from the Famine Early Warning Systems (FEWS) network.
} 
Sahelian zone, which has a chronic food production deficit. In some areas, the government's distribution of subsidized cereals has alleviated food shortages.

12. Most poor Chadians earn their living as laborers. Payment in kind is common, particularly during the pre-harvest hunger period, when food stocks are low and market prices are high. Throughout the country, cereal produced for own use is insufficient to meet poor households' food needs, especially because the poor must sell some production to meet other needs and pay off pre-harvest debts. Poor households sometimes supplement their income by gathering and selling firewood and gum Arabic and by conducting petty trade.

13. Middle and higher income households tend to make a living by producing goods for the market, through such activities as farming, raising livestock, and fishing. Livestock also serves as the primary source of wealth and savings among middle and higher income households, who, unlike the poor, can afford to send their cattle to neighboring countries when local grazing land is scarce. Richer households can also transport their products to more lucrative markets (e.g., abroad or to N'Djamena). Many Chadian households also participate in cross-border trade, exchanging livestock for manufactured goods and fuel from Sudan, the Central African Republic (CAR), Cameroon, and Nigeria.

14. In the transhumant livestock zone, livestock herds provide both food and cash income, making herd size a primary determinant of wealth. This large zone, which divides the desert north from the arable south, is where the transhumant herders searching for grazing lands start and end their annual migration. During migration, herders raise money for cereal by providing transportation, manuring fields, and selling their animals. Desertification and land degradation have pushed nomad herders further south, sparking conflicts between settled farmers and pastoralists.

15. Refugees from Sudan and the CAR are exacerbating the country's poverty and food insecurity. Though dire at first, food security among the more than 200,000 refugees from Sudan's Darfur area has improved steadily. Food security in some host communities, however, is high, particularly in the north. Because these areas have limited grazing lands, frictions between the refugees and the local populations have arisen, disrupting certain income-generating activities, such as the gathering of fuel-wood, straw, and wild plant products. The total number of CAR refugees in Chad is about 40,000, most of whom have been in the town of Amboko since 2002. With the Amboko camp nearing full capacity, a new camp being established farther away is expected to relieve pressure on the original camp and on local communities.

\section{Infrastructure}

16. Chad's infrastructure is extremely poor; there are no railways and very few paved roads outside N'Djamena. There are fewer than 5,000 kilometers of road for every 1 million inhabitants, and less than 1 percent of the roads are paved (compared with an average of more than 13 percent for the least developed countries). This lack of infrastructure makes it hard for many people to access food, and high rainfalls can isolate some areas for days, causing immediate spikes in local market prices. The cotton sector also lacks 
dependable access to infrastructure, creating low and unpredictable returns on investment among cotton farmers. In some cases, during heavy rains, large parts of the cotton harvest were left in the fields until the weather cleared, deteriorating the cotton's quality, delaying production, and ultimately reducing farmer income. However, an improved road network that will serve the petroleum industry could benefit the surrounding areas.

\section{Education}

17. Only about one-fourth of Chadian adults are literate, and the primary school enrollment rate is low (Table 2 and Figure 3). In 2002, 46 percent of the total population was literate. The literacy rate for women was even lower-less than 38 percent-indicating that the educational system is not gender neutral, though the ratio of girls to boys in primary and secondary schools has improved. Moreover, the net primary enrollment ratio has almost doubled since 1990, and the primary completion rate is increasing. These positive developments mainly reflect the large increase in the number of community schools, which finance teacher salaries through community fees. The system is particularly common in poor communities, where the government has not been able to provide teachers. Recently, the government has tried to pay the salaries of teachers working in community schools to reduce the burden on poor families.

18. The goal of universal primary education established in 1960 requires children to attend school until age 12. Nevertheless, the limited number of schools has hampered the development of standard curricula. The primary-school student-teacher ratio is about 70 and education expenditure is about half the Sub-Saharan-Africa average (Table 3). Only a small percentage of primary school children are enrolled in private schools.
Table 3. Chad: Government Spending on Education (latest available observations)

\begin{tabular}{lrr}
\hline & Chad & SSA \\
\hline Expenditure per student, primary (\% of GDP per capita) & 9.7 & $\ldots$ \\
Expenditure, total (\% of GDP) & 2.0 & 4.0 \\
Expenditure, primary education (\% of total education expenditure) & 57.5 & $\ldots$ \\
\hline Source: UNICEF &
\end{tabular}


Figure 3. Sub-Saharan Africa: Adult literacy rate ages 15 and above, in percent

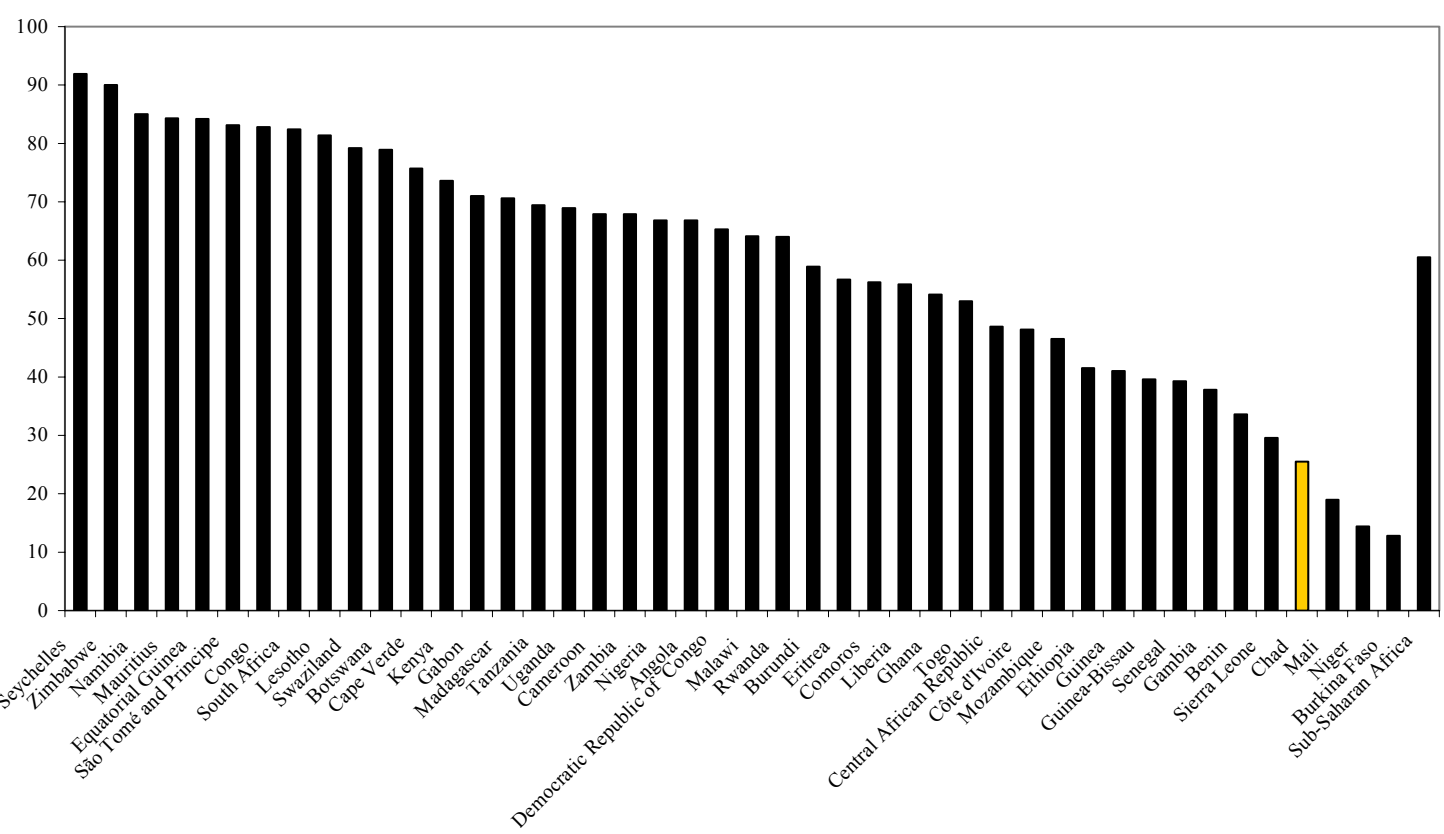

Source: UNDP, 2005 Human Development Report. Data mainly refer to national literacy estimates from censuses or surveys conducted between 2000 and 2004.

\section{Health}

19. Life expectancy in Chad-48 years-has not increased since the mid1990s. The population has grown at about 3 percent per year since 1990 and close to half of the population is under age 15. Important health indicators are dismal and not improving. The population per physician is about 30,000, and the under-five and infant mortality rates have not fallen since 1990 (Table 2). Recent government efforts, however, have improved some other indicators. For example, the immunization rate against measles more than doubled from 1997 and 2003, child malnutrition has decreased markedly, and the prevalence of below-minimum dietary energy consumption has decreased from one-half to one-third of the population. Per capita expenditure on health was US\$14 in 2002, less than half the average for Sub-Saharan Africa (Table 4). 
Table 2. Chad: Millennium Development Goals, 1990-2004 1/

\begin{tabular}{|c|c|c|c|c|c|}
\hline & 1990 & 1994 & 1997 & 2000 & 2002 \\
\hline \multicolumn{6}{|l|}{ Goal 1: Eradicate extreme poverty and hunger } \\
\hline Income share held by lowest $20 \%$ & .. & .. & .. & .. & \\
\hline Malnutrition prevalence, weight for age ( $\%$ of children under 5 ) & .. & .. & 39 & 28 & \\
\hline Poverty gap at $\$ 1$ a day (PPP) (\%) & .. & .. & .. & .. & \\
\hline Poverty headcount ratio at $\$ 1$ a day (PPP) (\% of population) & .. & .. & .. & .. & \\
\hline Poverty headcount ratio at national poverty line (\% of population) & .. & .. & 64 & .. & \\
\hline Prevalence of undernourishment (\% of population) & & & 49 & .. & \\
\hline \multicolumn{6}{|l|}{ Goal 2: Achieve universal primary education } \\
\hline Literacy rate, youth total (\% of people ages $15-24$ ) & 48 & .. & .. & .. & \\
\hline Persistence to grade 5 , total ( $\%$ of cohort) & & & & 54 & \\
\hline Primary completion rate, total (\% of relevant age group) & 16.6 & 18.4 & 15.8 & 22.9 & \\
\hline School enrollment, primary (\% net) & .. & .. & .. & 54 & \\
\hline \multicolumn{6}{|l|}{ Goal 3: Promote gender equality and empower women } \\
\hline Proportion of seats held by women in national parliament (\%) & .. & .. & 17 & 2 & \\
\hline Ratio of girls to boys in primary and secondary education (\%) & .. & .. & .. & 55.4 & \\
\hline Ratio of young literate females to males (\% ages $15-24)$ & 64.5 & .. & .. & .. & \\
\hline Share of women employed in the nonagricultural sector (\% of total nonagric empl) & 4 & .. & .. & .. & \\
\hline \multicolumn{6}{|l|}{ Goal 4: Reduce child mortality } \\
\hline Immunization, measles ( $\%$ of children ages $12-23$ months) & 32 & 24 & 30 & 42 & \\
\hline Mortality rate, infant (per 1,000 live births) & 117 & .. & .. & 117 & \\
\hline Mortality rate, under-5 (per 1,000) & 203 & .. & .. & 200 & \\
\hline \multicolumn{6}{|l|}{ Goal 5: Improve maternal health } \\
\hline Births attended by skilled health staff ( $\%$ of total) & & & 15 & 16.3 & \\
\hline Maternal mortality ratio (modeled estimate, per 100,000 live births) & .. & .. & .. & 1100 & \\
\hline \multicolumn{6}{|l|}{ Goal 6: Combat HIV/AIDS, malaria, and other diseases } \\
\hline Children orphaned by HIV/AIDS & & & & & 96 \\
\hline Contraceptive prevalence ( $\%$ of women ages $15-49$ ) & .. & .. & 4 & 8 & \\
\hline Incidence of tuberculosis (per 100,000 people) & 101.3 & .. & .. & .. & \\
\hline Prevalence of HIV, female (\% ages 15-24) & .. & .. & .. & .. & \\
\hline Prevalence of HIV, total (\% of population ages $15-49$ ) & .. & .. & .. & .. & \\
\hline Tuberculosis cases detected under DOTS (\%) & .. & .. & 14.5 & 36.8 & \\
\hline \multicolumn{6}{|l|}{ Goal 7: Ensure environmental sustainability } \\
\hline $\mathrm{CO} 2$ emissions (metric tons per capita) & 0 & 0 & 0 & 0 & \\
\hline Forest area $(\%$ of land area $)$ & 10 & .. & .. & 10 & \\
\hline GDP per unit of energy use (constant $2000 \mathrm{PPP} \$$ per $\mathrm{kg}$ of oil equivalent) & .. & .. & .. & .. & \\
\hline Improved sanitation facilities (\% of population with access) & 6 & .. & .. & .. & \\
\hline Improved water source (\% of population with access) & 20 & .. & .. & .. & \\
\hline Nationally protected areas (\% of total land area) & .. & .. & .. & .. & \\
\hline \multicolumn{6}{|l|}{ Goal 8: Develop a global partnership for development } \\
\hline Aid per capita (current US\$) & 51.8 & 31.2 & 30.5 & 15.9 & \\
\hline Debt service (PPG and IMF only, $\%$ of exports of G\&S, excl. workers' remittances) & 4 & 9 & .. & 14 & \\
\hline Fixed line and mobile phone subscribers (per 1,000 people) & 0.7 & 0.7 & 1 & 1.9 & \\
\hline Internet users (per 1,000 people) & 0 & .. & 0 & 0.4 & \\
\hline Personal computers (per 1,000 people) & .. & .. & .. & 1.3 & \\
\hline Total debt service (\% of exports of goods, services and income) & 4 & 9 & .. & .. & \\
\hline Unemployment, youth total (\% of total labor force ages $15-24$ ) & .. & .. & .. & .. & \\
\hline \multicolumn{6}{|l|}{ Other } \\
\hline Fertility rate, total (births per woman) & 6.7 & .. & 6.7 & .. & \\
\hline GNI per capita, Atlas method (current US\$) & 260 & 220 & 210 & 180 & \\
\hline GNI, Atlas method (current US\$) (billions) & 1.6 & 1.5 & 1.6 & 1.5 & \\
\hline Gross capital formation (\% of GDP) & 6.8 & 16.6 & 14.8 & 22.4 & \\
\hline Life expectancy at birth, total (years) & 46 & .. & 44.7 & 44 & 4 \\
\hline Literacy rate, adult total (\% of people ages 15 and above) & 27.7 & .. & .. & .. & \\
\hline Population, total (millions) & 6.1 & 6.8 & 7.5 & 8.2 & \\
\hline Trade (\% of GDP) & 41.4 & 50.3 & 50.5 & 54.4 & 7 \\
\hline
\end{tabular}

Source: World Development Indicators database, April 2006

1/ Figures in italics refer to periods other than those specified. 
20. The prevalence of HIV/AIDS is relatively low, though its human, social, and economic consequences cannot be ignored. The adult infection rate is 4.8 percent, compared with 6.4 percent for sub-Saharan Africa on average. This lower rate may reflect Chad's limited infrastructure, which makes it difficult for people to travel.

\section{Oil Revenue Inflows: Impact on the Poor}

21. With the coming on-stream of oil, the Chadian authorities must decide how they will allocate the newfound resources. First, they must decide whether to save or spend the bulk of the revenue. Any spending would need to be properly allocated between private and public spending. If opting for the private alternative, direct transfers to the population could be either conditional or unconditional, targeted or untargeted. This section explores several options that would allow the Chadian authorities to use oil revenues to reduce poverty and enhance economic growth. It then assesses the risks associated with such upfront spending.

\section{Saving for future spending}

22. Several oil exporting countries have established nonrenewable resources funds. Such resource funds put a share of government oil revenue away for possible use once oil revenues decline, owing to falling prices and/or depleted reserves (Davis et al., 2003). By contrast, a stabilization fund aims to reduce the impact of volatile revenue on the economy, and a savings fund seeks to preserve at least some wealth derived from nonrenewable resources for future generations (consistent with intergenerational welfare maximization models, savings funds can enable the government to keep real per capita spending constant by transforming oil wealth into financial assets). Both stabilization and savings funds, however, are often governed by overly rigid rules that do not reflect the fungible nature of budgetary resources: that is, by putting some money aside, on the one hand, while borrowing, on the other hand, does not increase the country's net wealth. Financing Funds (e.g., the Norwegian Oil Fund or the East Timor Oil Fund), while promoting transparency, fiscal sustainability, and macroeconomic stability, aim at overcoming this issue: oil resources finance the nonoil deficit, a goal stated in Chad's budget law and the MTEF.

\section{Assuming that government spending contains both an investment and a} consumption component, it could ultimately benefit the current generation as well as future generations. Taking into account the investment impact on productivity and the incentives it creates for private capital accumulation, Takizawa, Gardner, and Ueda (2004) show that countries with low capital stocks, such as Chad, benefit most if the government spends the bulk of accruing oil revenues with the aim of increasing the return to private investment and raising the country's growth rate. This result does not simply follow from the fact that marginal return on investment spending in Chad would be higher than the return on external financial assets. When the initial capital stock is low and government spending has positive externalities on production, the country would be better off spending more of its oil revenue upfront by increasing both the return to private investment and the country's rate of growth. Hence, if oil revenue investments lead to long-term benefits (e.g., health and 
education investments), then spending can permanently raise income, thus minimizing the tradeoff between current and future generations.

24. Given immediate development needs, the rationale for Chad to accumulate a savings fund is unclear. The financial return on a savings fund could fall far short of the social rate of return on well-selected infrastructure and human development projects. If borrowing costs exceed investment returns, oil-related revenues might also be better allocated to debt reduction. However, given Chad's high rate of corruption, authorities must make considerable efforts to improve governance. ${ }^{14}$

\section{Saving for stabilization purposes}

\section{Stabilization policy would aim to insulate the economy from short-term volatility}

in oil prices and revenues. Such a policy attempts to define a fiscal stance for a given medium-term projection of oil prices and revenues (Katz et. al, 2004). This gives policymakers a fiscal anchor and promotes avoiding erratic policies following oil price shocks. A carefully designed MTEF would cushion the economy from unexpected oil price fluctuations over the medium term, while maximizing long-term growth and poverty reduction. $^{15}$

\section{Public expenditure, efficiency, and absorptive capacity}

26. Market failures and social justice validate the public responsibility to provide services that have a direct link to human development-education, health, water, sanitation, and electricity. Because growth alone will not be enough to support Chad's achievement of the Millennium Development Goals (MDGs), and given the lack of a wellestablished tax system, the Chadian government should allocate a large share of the oil revenue to public expenditure, both at the central and local levels. The current government plan is to increase the provision of public services by increasing public expenditures in priority sectors: health and social affairs, education, infrastructure, rural development, and governance. The MTEF for the nine priority sector ministries for 2007-09 envisages significantly higher spending over the next few years compared with pre-oil 2003 levels. ${ }^{16}$ The MTEF objectives include:

- $\quad$ Ensure minimum access to all regions of the country-particularly during the rainy season. Linking major towns through a sufficient number of roads should improve access to food and trade, especially among the rural poor. The cost of transportation should also fall as efficiency improves. These measures should improve livelihoods of the rural poor, who suffer the most from the temporary lack of access to markets because of impassable roads. It is estimated that public investment in infrastructure should absorb one third of the resources allocated to priority sectors.

\footnotetext{
${ }^{14}$ Out of 159 countries, Chad ranks last on Transparency International's 2005 Corruption Perceptions Index.

${ }^{15}$ Although established under Chad's oil revenue management law, a stabilization mechanism that offsets the effect of an oil revenue shock has never been used.

${ }^{16}$ Because the 2006 MTEF is still in draft form, this chapter refers to the 2005 MTEF adopted by the Council of Ministers. Because actual oil revenue was lower than projected, 2005 priority sector spending was scaled down significantly from the budgeted amount.
} 
- Increase agricultural production through efforts to improve credit, research, and input supply. These instruments to raise agriculture productivity, increase cattle production, and achieve agricultural-led growth should also support efforts to increase caloric intake by more than 25 percent, an objective stated in the Poverty Reduction Strategy Paper (PRSP).

- Improve human capital by increasing education access (particularly among girls), improving primary education, and reducing illiteracy. The MTEF's human capital objectives are to reach a net primary enrollment ratio of 95 percent in 2007 and to expand literacy-program coverage from 120,000 people in 2005 to 160,000 in 2007. The budgetary allocations for the education sector are expected to double from their 2000-03 levels. ${ }^{17}$

- $\quad$ Provide 80 percent of the population an adequate and accessible basic health care system by 2007. Specific goals include reducing the maternal and child mortality, the HIV/AIDS rate, and the incidence of tuberculosis and malaria. The program also aims to reduce unequal access to health services across regions, increase the number of doctors and pharmacists, and raise the availability of drugs to sufficient levels. In addition, 4 new hospitals and 80 health centers will be constructed, and about 40 existing health centers will be rehabilitated.

27. The mere scaling up of services will not be sufficient to significantly reduce poverty; a well-functioning public sector is a crucial foundation for service delivery reform. A considerable problem for scaling up spending in Chad is the lack of absorptive capacity, particularly in priority sectors. Even before the inflow of oil revenue, budget execution in priority sectors was consistently lower than in nonpriority sectors.In using the additional resources, the government must further emphasize capacity building measures to keep up a higher level of spending while increasing the quality of such spending. Thus, sectoral reforms must be linked to ongoing capacity building and public sector reforms in such areas as budget management, decentralization, and public administration reforms. To avoid corruption, safeguards against banditry must also be enforced.

28. The ultimate goal of such efforts - to build up to, and maintain, higher levels of consumption-may not be achievable through public spending alone, mainly because of physical capacity constraints. In the short and medium term, shortages of skilled personnel and entrepreneurial capacity may hamper efforts to raise private consumption. Accordingly, providing direct transfers to individuals might thus be a viable complement to other program components.

\section{Cash transfers}

29. Some analysts support distributing oil revenues directly to the population through the implementation of a direct cash transfer system. They believe this system is

\footnotetext{
${ }^{17}$ Although the overall increase for primary education is substantial and appears adequate, the increase for tertiary education is offset by keeping the allocation for secondary education stable, most likely resulting in negligible effects on poverty reduction.
} 
advantageous in that it provides beneficiaries with additional income that can be optimized according to personal preference. ${ }^{18}$ Compared with in-kind transfers, cash transfers do not cause price distortions or create secondary markets. Such transfers could reduce cash constraints among the poor and smooth consumption during the pre-harvest hunger gap. Studies have shown that cash transfer programs in several developing countries have resulted in higher consumption levels, particularly for food, and helped protect the poor in times of crises (Rawlings and Rubio, 2005). The additional income may also lift some people out of the poverty trap, allowing them to engage in private sector activities beyond subsistence level. ${ }^{19}$ Hence, a cash transfer may lead to increased savings by the poor, most likely in the form of livestock, given Chad's lack of financial services. ${ }^{20}$ Combined with structural reforms to improve the business climate, cash transfers may thus boost economic performance. In the longer term, increased demand for financial intermediation may contribute to the development of Chad's financial sector.

\section{Conditional cash transfer programs (CCT), recently introduced in Latin} America, are an innovative and increasingly popular approach to social assistance delivery (Box V.1.). ${ }^{21}$ By making cash assistance to poor families contingent on certain actions, usually investment in human capital, the programs represent a new approach to longterm social assistance and have helped alleviate poverty. To be efficient, however, program management must be rooted in strong government agencies, a foundation that Chad is currently lacking. Moreover, the programs require sufficient investment in the supply and quality of social services to satisfy increased demand - conditions that are hard to meet in most sub-Saharan African countries. In a country without sufficient services, CCT programs risk mandating that the poor use low-quality health and education services, thus undermining the programs' potential impact on long-term welfare (World Bank, 2004). In sub-Saharan Africa, given the weak government institutions and poor quality of health and education services, unconditional cash transfer programs that are finely targeted to the poor might have more success (Save the Children UK et al., 2005).

\footnotetext{
${ }^{18}$ Some analysts argue the consumption pattern of one-time cash transfers, which is similar to winning a lottery, may not be optimal over time. However, cash transfers of oil revenues to individuals, carried out on a regular basis, could help raise income levels for longer periods. Although consumption patterns may be erratic in the short term, but they would likely normalize over the medium term.

${ }^{19}$ A poverty trap is defined as a vicious circle of low savings and few investment opportunities. According to Sachs et al. (2004), Africa is stuck in such a trap, unless it gets a "big push" lasting some two decades.

${ }^{20}$ In their cross-country study, Sala-i-Martin and Subramanian (2003) found that the private, versus the public, sector uses savings more efficiently.

${ }^{21}$ For further discussion of CCT programs, see Country Report No. 05/153 for Namibia.
} 


\section{Box 1. Conditional Cash Transfer (CCT) Programs}

\section{Recently developed CCT programs are an innovative way to deliver social} services. Such programs provide money to the poor conditional on investments in human capital. By design, they address both future poverty, by fostering the buildup of human capital over time, and current poverty, by providing direct income support. These programs are meant to address the failures of traditional supply-side interventions, such as the provision of schools and health clinics, which the poor often underuse owing to cash constraints, high opportunity costs, difficult access, and lack of incentives.

CCT programs typically make children the primary group for human capital investments and monitor compliance with conditions. The programs typically include (i) a cash grant conditional on school enrollment and regular school attendance, covering direct and/or opportunity costs for primary and secondary education, and/or (ii) a cash grant targeted to the following groups: children ages two to three or up to primary school age, lactating and pregnant mothers, and other adult household members (for health center visits, health and nutrition workshops, yearly check-ups, prenatal health care, child growth monitoring, and vaccinations).

By some measures, CCT programs have increased school enrollment rates, improved preventive health care, and raised household consumption. In addition, successive governments have both continued and expanded program coverage, suggesting that the stated goals are being met and are politically feasible. The programs, which are targeted according to geographic and/or household information, have been implemented gradually and with close monitoring to address logistical complexities, fiscal constraints, uncertainty about the magnitude of program impacts, and concerns about corruption and mismanagement. Program eligibility is reviewed periodically. In general, total costs have been below 1 percent of GDP, and administrative costs appear to be small.

1/ This box draws on Das, Do, and Özler, (2005); Rawlings and Rubio (2005); and World Bank (2004).

\section{To increase Chad's current social spending, a program using oil revenue to} finance a cash transfer conditional on school enrollment was deemed premature. By some arguments, spending resources on today's schoolchildren would help reduce poverty over time as well as improve several MDG indicators. ${ }^{22}$ However, given the low standards of Chad's current education sector, such a proposal is likely to have limited success. Instead, a

\footnotetext{
${ }^{22}$ A transfer tied to number of children may result in unintended fertility increases. In Brazil, this externality has been addressed by limiting the transfer to three children per family.
} 
cash transfer conditional on the use of more basic social services (e.g. participation in immunization drives or in HIV/AIDS awareness and nutritional education programs) might be more appropriate.

\section{Risks associated with upfront spending}

\section{Counteracting the obvious positive effects of spending the oil revenue upfront, there are several risks associated with such spending:}

- Institutional capacity is weak and corruption widespread, which may lead to wasted resources.

- Inflation may pick up, given that absorptive capacity is low.

- $\quad$ As spending increases, people may become accustomed to higher consumption, both in terms of services and public sector wages, and may find it difficult to adjust to lower consumption once oil revenues start to decline. ${ }^{23}$ This could jeopardize macroeconomic stability and fiscal sustainability.

- Unless some precautionary savings are maintained, highly volatile oil prices and production levels could disrupt spending allocations.

However, institutional capacity should improve as capacity-building measures and public sector reforms are implemented. And while absorptive capacity improvements must guide spending increases, spending should be allocated to growth-enhancing investments that in turn raise absorptive capacity. ${ }^{24}$ Finally, given Chad's low life expectancy, high child mortality, and high poverty rate (two-thirds of the population are poor), the opportunity horizon in Chad is short. Thus, the cost of habit formation may be small compared with the cost of postponing spending. In addition, arguments to save the oil revenue until it can be spent more productively assume that the funds would be better spent in the future. In sum, there is a strong argument for increasing oil revenue-related spending today if the social discount rate is higher than the sum of the return on savings and the rate of improvement in public spending efficiency.

\section{E. Conclusions and Recommendations}

\section{Cutting poverty in half by 2015 through the efficient redistribution and utilization of oil revenue will be a challenge for Chad. Given Chad's low development}

\footnotetext{
${ }^{23}$ Habit formation was developed in the consumption literature to capture the idea that consumption is addictive - the amount of utility derived from consumption today depends negatively on how much was consumed yesterday. Habit formation can also be seen in terms of the institutional and political economy adjustment costs facing policymakers (e.g., cutting the public sector wage bill abruptly may not be politically feasible).

${ }^{24}$ In fact, Agénor et al. (2005) show that, for Niger, the initial inflationary effect of higher aggregate demand from higher foreign capital inflows is dampened over time. An increase in foreign capital that leads to higher (more efficient) public investment in infrastructure, health, and education improves the quality of labor used in production. This supply-side effect lowers inflation. In addition, a high import component of spending reduces inflationary risks.
} 
level, there are persuasive arguments for spending most of the oil revenue upfront, within the parameters of a carefully designed MTEF. Although the current plan to increase the provision of public services and scale up public expenditures in priority sectors seems appropriate, the MTEF would at the same time cushion the economy against unexpected oil price fluctuations. ${ }^{25}$ However, given the economy's lack of absorptive capacity, sectoral reforms must be linked to ongoing capacity building.

\section{Through the implementation of a well-prepared MTEF, the Chadian authorities} would have an unprecedented opportunity to alleviate poverty. Primarily, food security must be reinforced and agricultural and cotton sector productivity improved through the development of infrastructure, agricultural credits, irrigation, and other improvements. To improve Chad's human capital, investment in health and education must also be increased. One of the greatest challenges of Chad's public sector is its lack of trained personnel. Resources should also be targeted to institutional development and improved governance, factors that will be crucial to creating a more efficient and attractive private sector. Such improvements should also help raise productivity levels, improve absorptive capacity, and boost growth rates in the years to come.

35. With the bulk of oil revenues being used to further increase capacity buildingthrough the efficient development of the MTEF for the priority sectors-a certain share of the oil revenue could arguably finance direct transfers to the Chadian population to alleviate immediate poverty. Given Chad's high poverty rate, short life expectancy, and low level of education, well-targeted transfers to the poor, conditional on investment in human capital, would address both efficiency and equity arguments. However, to make such conditional transfers successful in eradicating future poverty, they must be complemented by an important scaling up of the supply and quality of social services (e.g., schools, teachers, health clinics, doctors, and nurses). Until such staffing and services reach an appropriate scale, a medium-term solution could be to introduce an unconditional cash grant targeted at vulnerable groups (e.g. children and pregnant women in rural areas) or make it conditional on the provision of more basic social services.

\footnotetext{
${ }^{25}$ The purpose of this exercise is to explore the options in maximizing growth and poverty reduction over time, not to identify an optimal long-term fiscal policy rule for Chad.
} 


\section{References}

Agénor, P., N. Bayraktar, E. Pinto Moreira, and K. El Aynaoui, 2005, “Achieving the Millennium Deveoplment Goals in Sub-Saharan Africa: A Macroeconomic Monitoring Framework," World Bank Policy Research Working Paper 3750 (Washington: World Bank), October.

Das, J., Q.-T. Do, and B. Özler, 2005, "Reassessing Conditional Cash Transfer Programs," The World Bank Research Observer, Vol. 20, No. 1 (spring).

Davis, J., R. Ossowski, J. A. Daniel, and S. Barnett, 2003, "Stabilization and Savings Funds for Nonrenewable Resources," in Fiscal Policy Formulation and Implementation in OilProducing Countries, ed. by J.M. Davis, R. Ossowski, and A. Fedelino (Washington: International Monetary Fund).

Hausmann, R., and R. Rigobon, 2003, "An Alternative Interpretation of the 'Resource Curse': Theory and Policy Implications," in Fiscal Policy Formulation and Implementation in Oil-Producing Countries, ed. By J.M. Davis, R. Ossowski, and A. Fedelino (Washington: International Monetary Fund).

International Monetary Fund, 2006, Namibia: Selected Issues and Statistical Appendix, Country Report No. 05/153 (Washington: International Monetary Fund).

Katz, M., U. Bartsch, H. Malothra, and M. Cuc, 2004, "Lifting the Oil Curse: Improving Petroleum Revenue Management in Sub-Saharan Africa," (Washington: International Monetary Fund).

Rawlings, L. B., and G. M. Rubio, 2005, "Evaluating the Impact of Conditional Cash Transfer Programs," The World Bank Research Observer, Vol. 20, No. 1 (spring).

Sachs, J., J. McArthur, G. Schmidt-Traub, M. Kruk, C. Bahadur, M. Faye, and G. McCord 2004, "Ending Africa's Poverty Trap," Brookings Papers on Economic Activity 1.

Sala-i-Martin, X., and A. Subramanian, 2004, "Addressing the Natural Resource Curse: An Illustration from Nigeria,” NBER Working Paper No. 9804 (June).

Save the Children UK, HelpAid International, and Institute of Development Studies, 2005, "Making Cash Count: Lessons from Cash Transfer Schemes in East and Southern Africa for Supporting the Most Vulnerable Children and Households."

Takizawa, H., E. H. Gardner, and K. Ueda, 2004, "Are Developing Countries Better Off Spending Their Oil Wealth Upfront?," IMF Working Paper WP/04/141 (Washington D.C., International Monetary Fund).

World Bank, 2004, “A New Approach to Social Assistance: Latin America’s Experience with Conditional Cash Transfer Programs," Social Safety Nets Primer Notes, No. 15. 


\section{Assessing Competitiveness In CHAD IN Light OF OIL ${ }^{26}$}

\section{A. Introduction}

1. Chad is one of the poorest countries in the world. When oil began flowing in 200304, there were strong expectations that it would be a panacea for this land-locked desert nation. Revenues were to be tightly controlled by a Petroleum Revenue Management Law (PRML), passage of which the World Bank required as a condition of its participation in developing the sector. Leaving aside the controversial question of the use of oil revenues, oil exports have radically altered the profile of Chad's economy. What has this meant for the rest of the economy and Chad's non-oil export sector? This paper is a preliminary exploration of the impact of oil on Chad's competitiveness.

2. The basic theory of Dutch disease, as applied to a fixed exchange rate regime, is that if inflows from exports (such as oil) are not held as reserves, used solely on imports, or adequately sterilized, they will increase the domestic money supply and ignite inflation. The ensuing inflation premium causes a change in relative prices and appreciation of the real exchange rate. Applying a theory of one price, another interpretation might be that oil production would increase efficiency and lower prices within the export sector as a whole. As a result, the nontradables sector becomes more costly and pays higher wages, so entices labor away from the traditional export sectors.

3. This paper concludes that there are some signs of real exchange rate appreciation in Chad, although the period for which data are available is very short and data quality is poor (Box 1). Because Chad is a member of the Central African Economic and Monetary Community (CEMAC), the Chadian authorities have limited flexibility in changing monetary and fiscal policies to neutralize real exchange rate appreciation. Structural policies are therefore crucial to maintaining competitiveness. In the end, the most important and effective policies to retain or boost competitiveness will be those that facilitate an increase in productivity in the non-oil economy.

4. The paper is structured as follows. Section B reviews Chad's external sector for the period 1994-2004 and how the composition and direction of trade changed with oil production. Section $\mathrm{C}$ discusses measures of the real exchange rate and CEMAC-wide competitiveness. Section D discusses possible policy responses to increases in the real exchange rate, and Section E draws conclusions.

\section{B. The External Sector Through 2004}

5. In the last four years, external sector developments have been dominated by the coming online of oil production. In 2002-03 when the Chad-Cameroon pipeline was being constructed, the current account balance plummeted to a deficit of 99 percent of GDP. With production coming on line in the second half of 2003 and in full swing in 2004, the current

\footnotetext{
${ }^{26}$ Prepared by Laure Redifer
} 
account balance sharply reversed itself, moving to a surplus by 2005 (Figure 1). ${ }^{27}$ As was to be expected, services imports increased with oil exports.

\section{Box 1: Data Limitations in Chad}

The insights in this paper are constrained by data limitations, in terms of both quality and quantity. BOP data are available only on an annual basis. The first full year of oil production, 2004, is also the most recent year for which disaggregated export data are available. Only preliminary 2005 balance of payments data are available. There are no data available on productivity and real wages.

Moreover, data collection methodologies are not reliable. Because Chad's balance of payments data are compiled from surveys of large exporting companies rather than customs data, they are subject to errors and frequent revision. Huge revisions of the 2002 balance of payments data were made in 2005 based on new information provided by the oil consortium. The revisions showed that there had been large errors and omissions and large swings in short-term capital flows in the crucial pipeline construction years.

It appears from the recent data revisions that oil-related imports increased sharply in 2002, but all other import categories declined markedly in that year only. This raises a question whether non-oil import figures might have been revised to reduce the size of the change in the aggregated number. For example, in 2002, a more extensive multi-country survey was conducted on intra-CEMAC livestock trade; as a result, Chad's livestock export numbers were almost tripled in 2003. The Bank of Central African States (BEAC), which produces balance of payments data for Chad, chose not to revise the estimates of livestock exports retroactively.

Data on the direction of trade, especially in recent years, are inconsistent with the figures provided by trading partners. Also, the significant 2002 revisions are reflected in current account data but not in the data on the composition or direction of trade. This paper mostly uses partner country trade data.

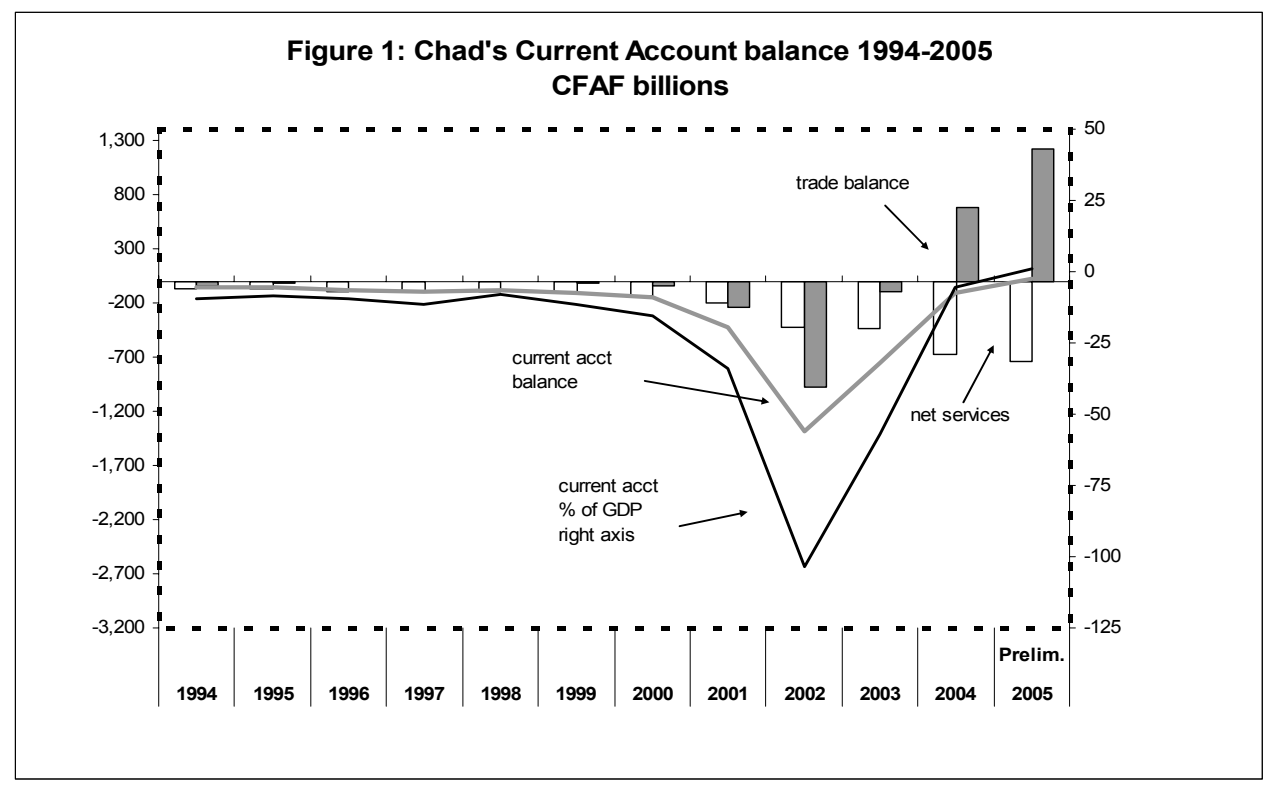

${ }^{27}$ Balance of payments data for 2005 are still estimates by the BEAC (Banque des Etats de L'Afrique Centrale). 
6. The coming online of oil has radically altered export composition, direction, concentration, and weight in GDP (Figure 2). Chad's traditional exports - cotton, livestock, and gum arabic - have been overshadowed by oil in recent years. Exports as a percentage of GDP increased from 10 percent in 2002 to 64 percent in 2005. Non-oil exports as a percentage of non-oil GDP have stayed relatively constant at around 14-16 percent. Cotton exports did fall as oil production came on line, but this was because international and local prices were falling. The cotton sector has suffered from significant infrastructure problems, including the near-bankruptcy of the state cotton company. The apparent increase in livestock exports at the same time occurred because new estimating methodology doubled the size of exports but was not applied retroactively.

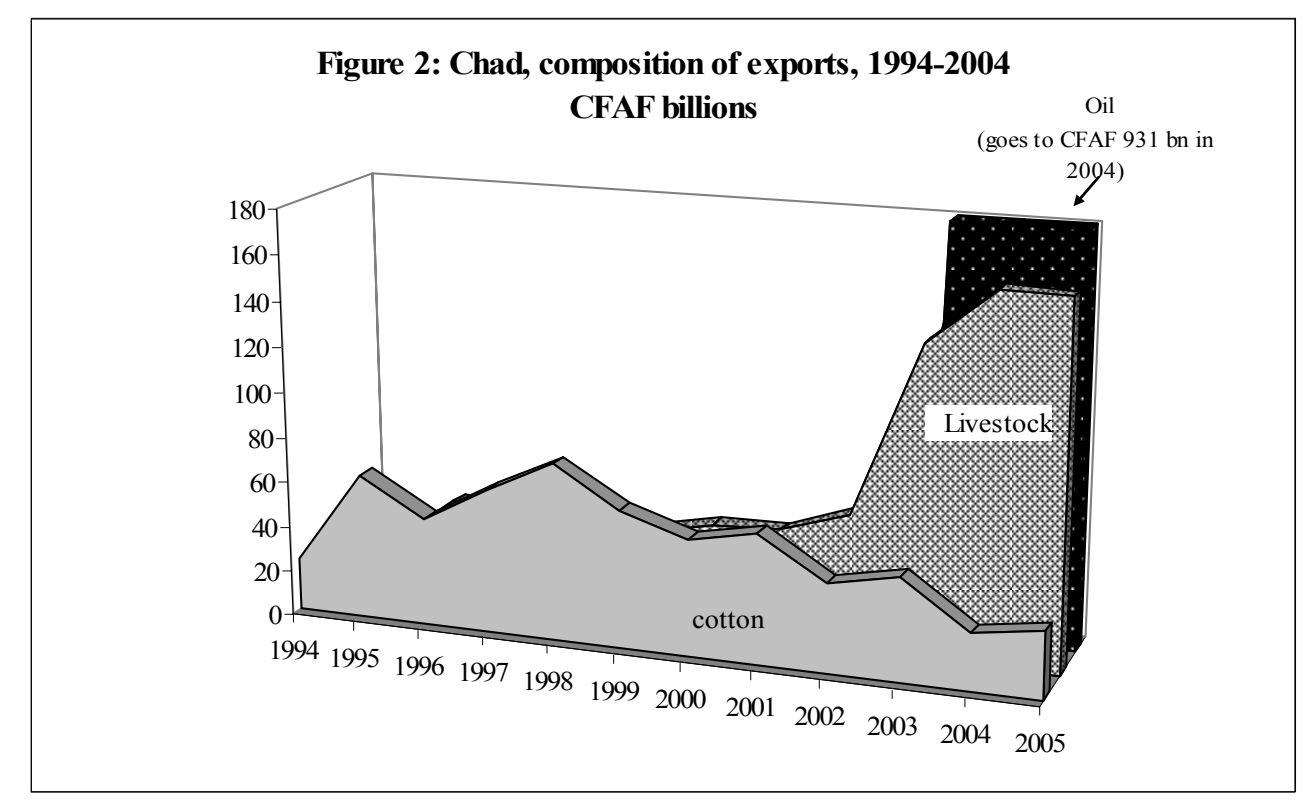

7. Data on the direction of trade confirm that oil exports have changed its

orientation. Trade within CEMAC and sub-Saharan Africa appears to be low, but data drawn from Chad's trading partners, do not reflect recent large balance of payments revisions or the new calculations of livestock exports, which are almost exclusively directed to the CEMAC region and Nigeria. Before oil was found, most exports went to the European Union; now, oil exports show a major reorientation to North America and Asia (Figures 3). 


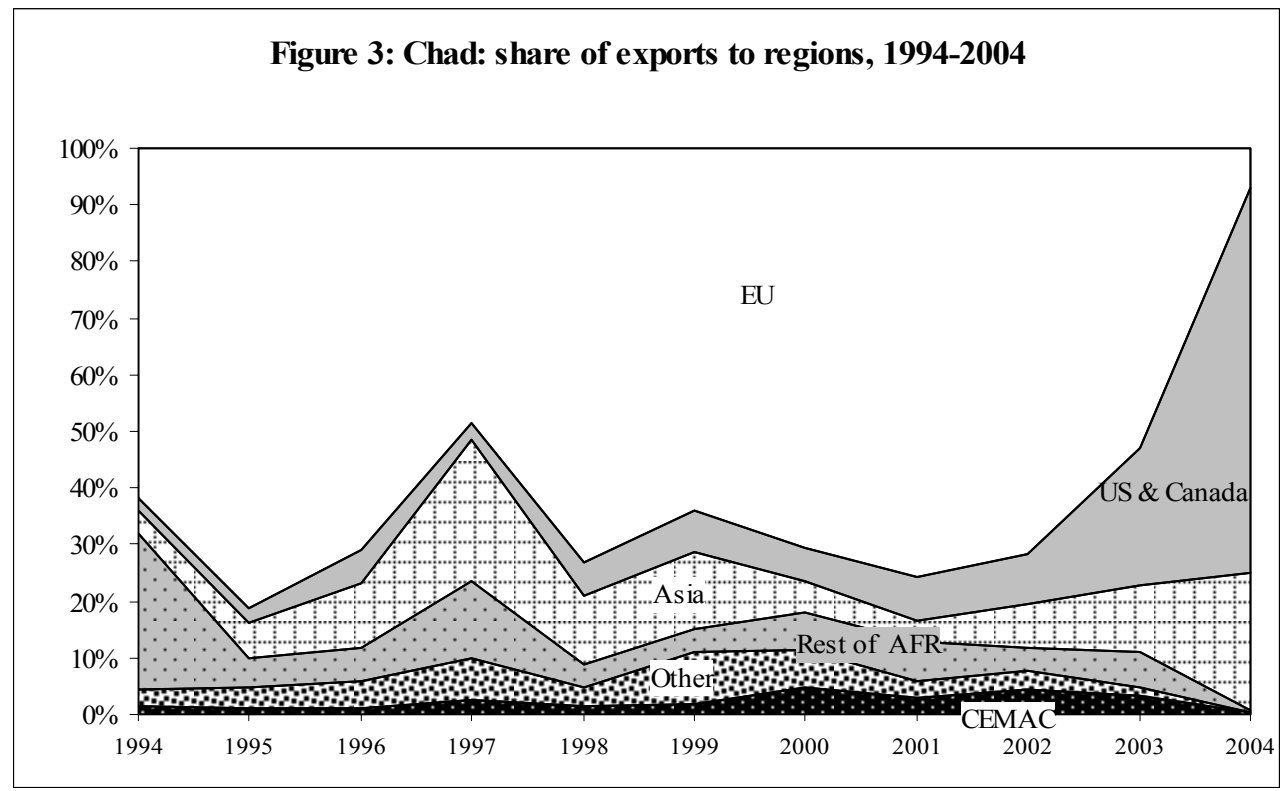

8. Chad's non-oil imports are concentrated in equipment, intermediary goods, consumption goods, and energy (Figure 4). Except when the pipeline was being constructed, imports have held at around 18-20 percent of GDP. Continued strong imports for non-oil equipment and intermediary goods suggests that demand for inputs for traditional export sectors has not waned because of oil production. The buoyant rise in all categories of imports may indicate stronger domestic demand.

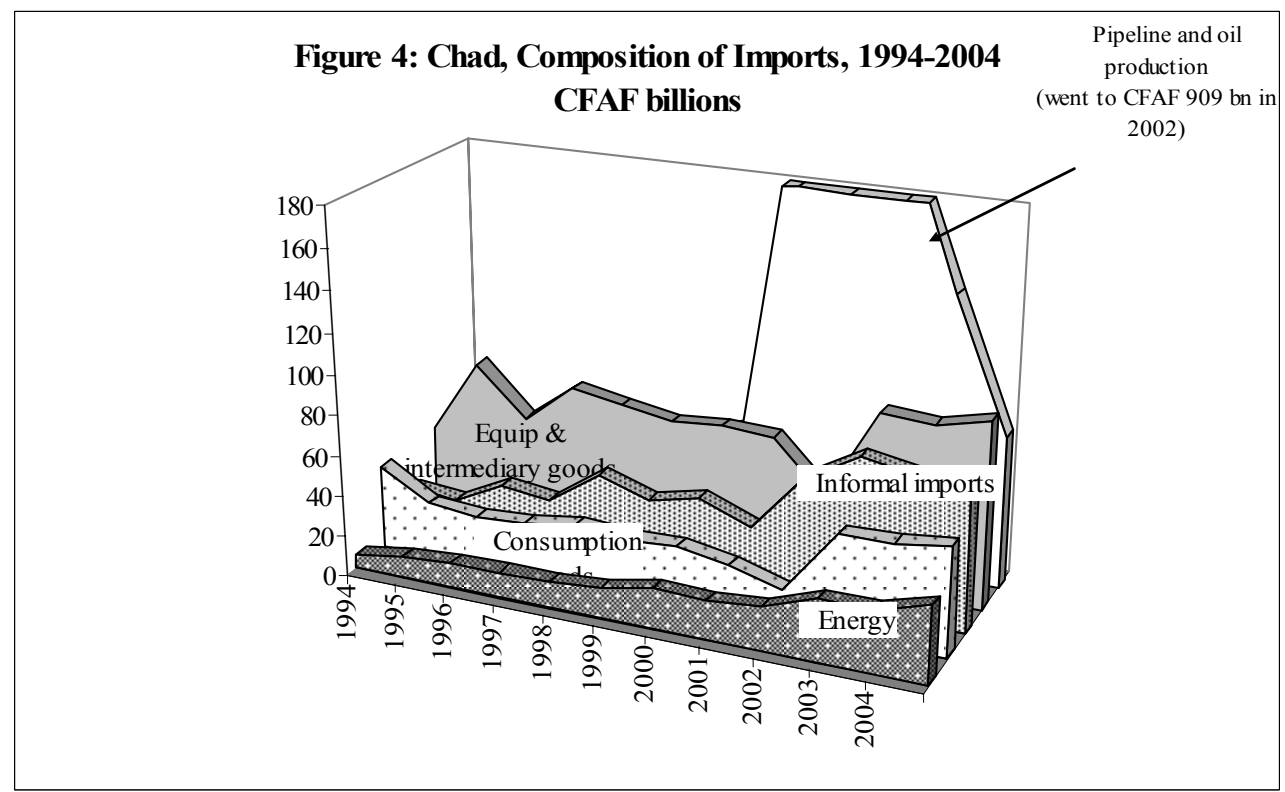

9. Before the pipeline and oil production facilities were constructed, Chad's imports were predominantly from the EU. Imports from the U.S. and Canada in 2001-03 were primarily oil-related. While the share of imports from these countries has since declined, it is likely to remain somewhat higher than in the pre-oil era as long as 
oil is flowing. Imports from within CEMAC have increased at the same time, probably reflecting increased informal trade.

\section{B. Measures of Competitiveness.}

\section{The real effective exchange rate (REER) is the most straightforward} method for assessing competitiveness. It generally measures purchasing power in a country compared with its trading partners by using relative prices and the nominal exchange rate. ${ }^{28}$ If the law of one price holds - that is, the price of tradables equalizes between countries - the real exchange rate can also be calculated as a ratio of the price of non-tradables to tradables in the home country. ${ }^{29}$ In other words, if the price of nontradables goes up relative to tradables - the real exchange rate rises and competitiveness is lost. In the theory of Dutch disease, natural resource windfalls cause a shift in resources from the nontradables to the tradables sector, making the former relatively more costly and implying an appreciation in the real exchange rate and a loss of competitiveness. In that case productivity growth would be the only way to stay competitive. In practice, the theory of one price usually does not hold, even for goods that seem to be purely tradable, owing to transport costs, official trade barriers and noncompetitive market structures. ${ }^{30}$

\section{The Fund's database shows that Chad's REER appreciated by over} 10 percent from before the 1994 devaluation through fall 2005 . The change is composed of a fairly large nominal appreciation and a less pronounced increase in relative prices (Figure 5).

\footnotetext{
${ }^{28}$ Producer prices, GDP deflator, and unit labor costs are some ways other than consumer prices to measure relative price changes. Only the CPI and the GDP deflator are available for Chad.

${ }^{29} \mathrm{P}=\mathrm{P}_{\mathrm{NT}}{ }^{\alpha} \mathrm{P}_{\mathrm{T}}^{1-\alpha}$. Domestic prices are composed of both the nontradables and tradables sectors.

$\mathrm{RER}=\mathrm{e} \mathrm{P} / \mathrm{P}^{*}$. The real effective exchange rate is equal to domestic prices relative to international prices adjusted by the nominal exchange rate. According to the theory of one price, $\mathrm{P}^{*}=\mathrm{e}_{\mathrm{T}}$ if prices in the nontradables sector adjust to international prices adjusted by the nominal exchange rate. Then $\mathrm{RER}=\mathrm{e}\left(\mathrm{P}_{\mathrm{NT}}{ }^{\alpha} \mathrm{P}_{\mathrm{T}}{ }^{1-\alpha}\right) / \mathrm{e} \mathrm{P}_{\mathrm{T}}=\left(\mathrm{P}_{\mathrm{NT} /} \mathrm{P}_{\mathrm{T}}\right)^{\alpha}$. The real exchange rate is the price of nontradables relative to tradables. ${ }^{30}$ Obstfeld and Rogoff (1999) and Froot and Rogoff (1995).
} 
Figure 5: Chad's Exchange Rates and Relative Prices,

December 1993-September 2005

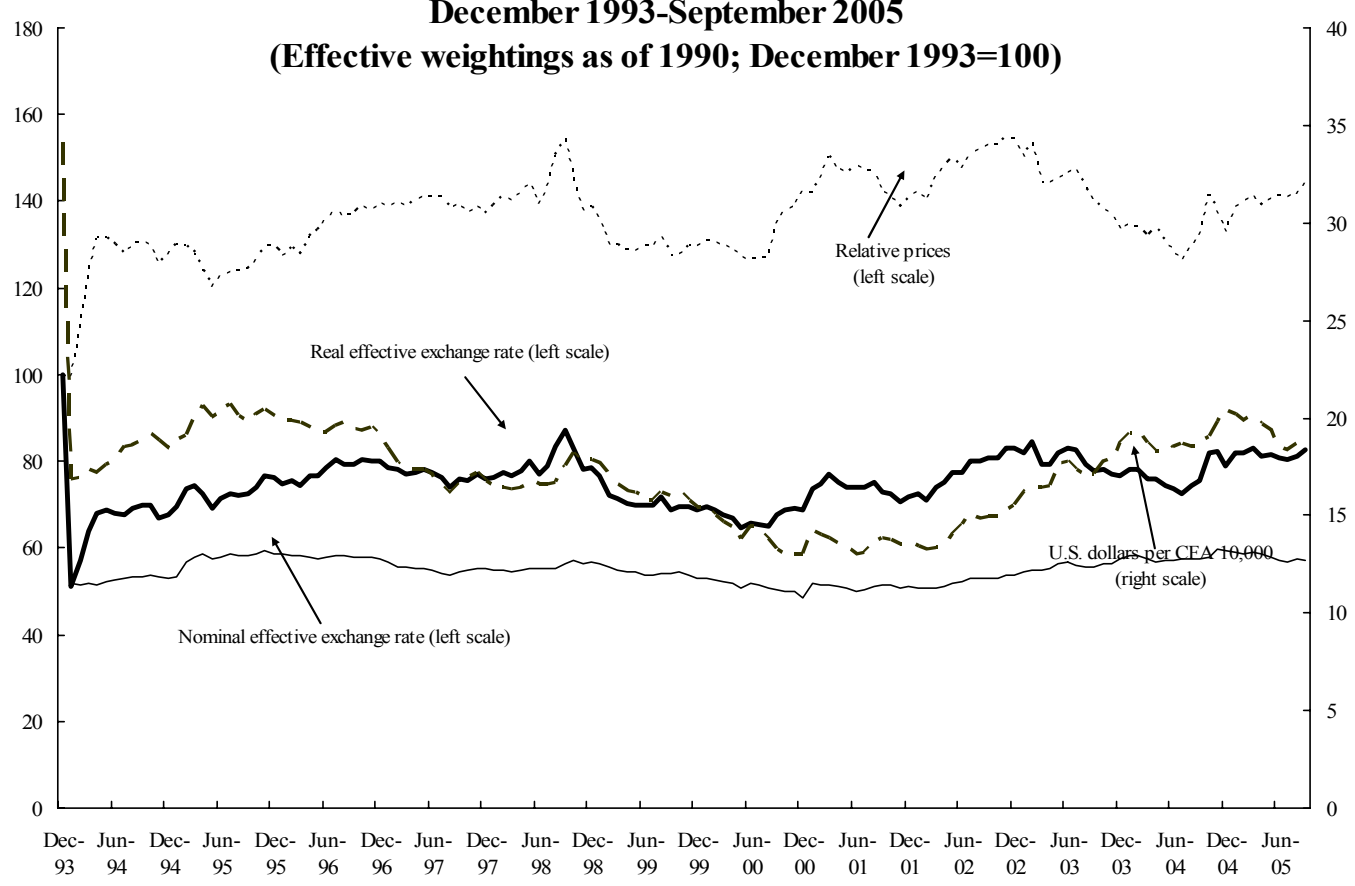

Source: IMF Information Notice System

\section{The radical change in Chad's external trade should in theory put more weight on the US dollar/euro relationship in determining the country's} competitiveness, since the CFAF is pegged to the euro. A new REER series had to be constructed to reflect the change in Chad's direction of trade. Although the weights for the Fund's REER measures were changed from 1990 to 2000, the latter year still predates the radical shift in Chad's direction of trade. For this paper, the REER was reconstructed using weights that give more prominence to relative prices for North America than for other regions. ${ }^{31}$ While changing the weights gives US dollar movements against the euro a higher weight in the nominal effective exchange rate, there is little change for relative prices because U.S. and euro-area inflation generally move in tandem. Indeed, applying the new weights relative to the old over the same period indicates that the nominal effective exchange rate has a more profound effect on REER movements than relative prices. ${ }^{32}$

\footnotetext{
${ }^{31}$ This was done using the Fund's effective exchange rate facility. However, since the direction of trade of imports was affected less than the direction of exports (it was only affected profoundly while the pipeline was being constructed), the weights were not changed dramatically.

${ }^{32}$ Using the Fund's effective exchange rate facility to recalculate effective exchange rates and relative prices and giving a higher weighting for the US (45 percent) and Asia shares of trade relative to Europe (45 percent) reveals more REER appreciation. Comparing new and old weightings for January 2001-August 2005 shows a 23 percent increase in the REER (10 percent using the old weightings) composed of a increase in the nominal
} 
13. Using the modified weighting scheme with a heavier weight for the US dollar, the increase in the REER since Chad's oil production has come on line appears to be driven almost exclusively by changes in the nominal effective exchange rate. Using a modified weighting scheme and rebasing the series to 100 in July 2003, from January 2003-August 2005 the REER increased by 3.7 percent, reflecting a 3.7 percent increase in the nominal exchange rate and no change in relative prices over the period, although there was considerable vacillations within the period ${ }^{33}$ (Figure 6). This suggests that the weakness of the U.S. dollar relative to the euro could be the main source of Chad's loss of competitiveness rather than the oil sector.

Figure 6: Chad Exchange Rates and Relative Prices, Modified Weights

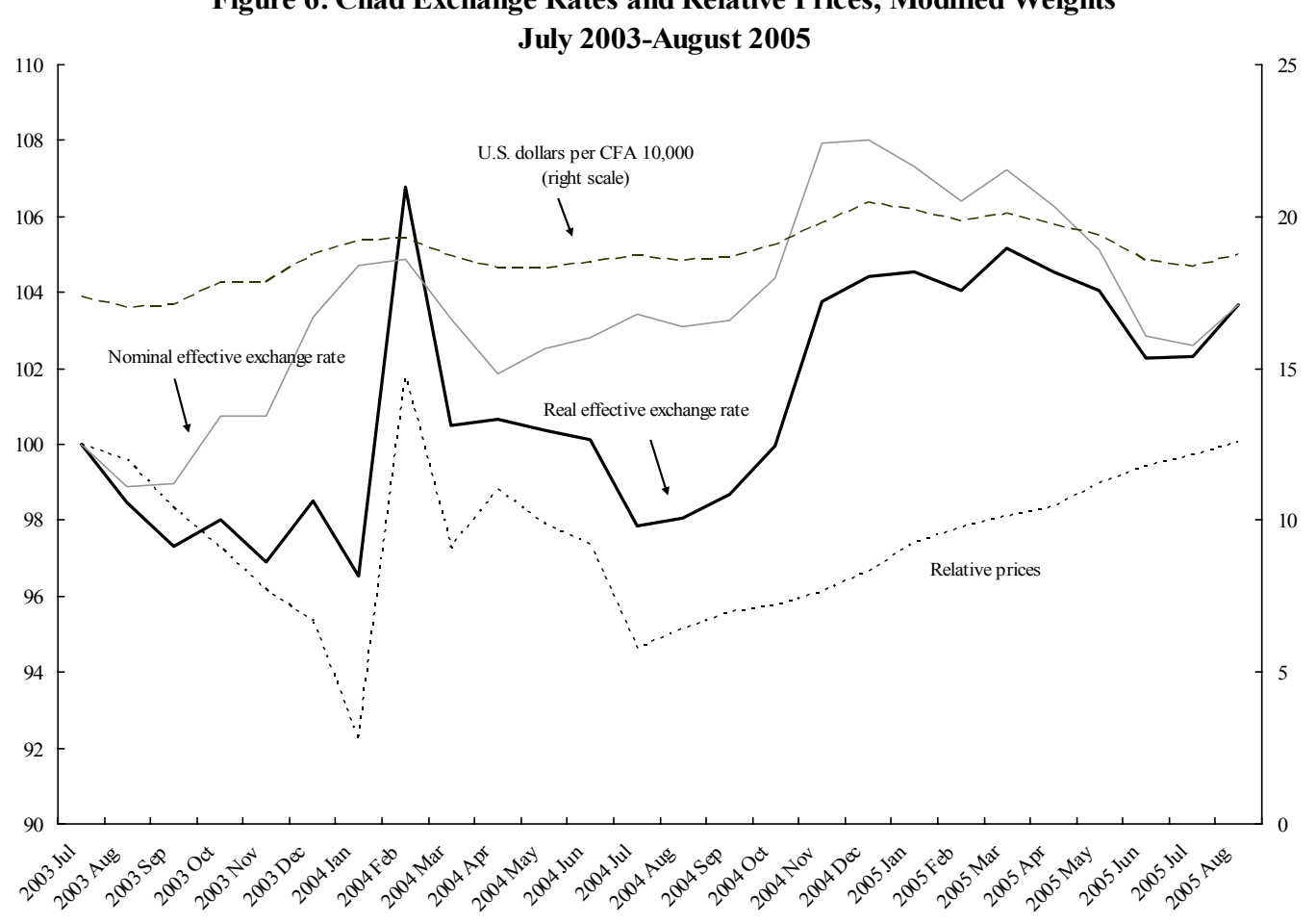

14. Assuming that the law of one price holds to some extent, another way to assess competitiveness is the internal exchange rate - the price of non-tradables relative to tradables in the country itself. The internal exchange rate also seems to have increased in Chad since oil came on line. A REER was constructed by classifying detailed CPI categories as tradable or non-tradable and creating weighted index for each. Oil itself was excluded Figure 7 shows that prices of nontradables have been increasing more than those of tradables. A main source of inflation in Chad has been food shortages, especially of cereals, but since cereals are included in the tradables index, they are not responsible for the movement of non-tradables.

effective exchange rate of 15 percent (10 percent using the old weightings) and an increase in relative prices of 7 percent (5 percent using the old weightings). The recalibration forces the relationship to add properly.

${ }^{33}$ Using the old weighting system, the REER depreciated 1.6 percent between July 2003 and September 2005. 


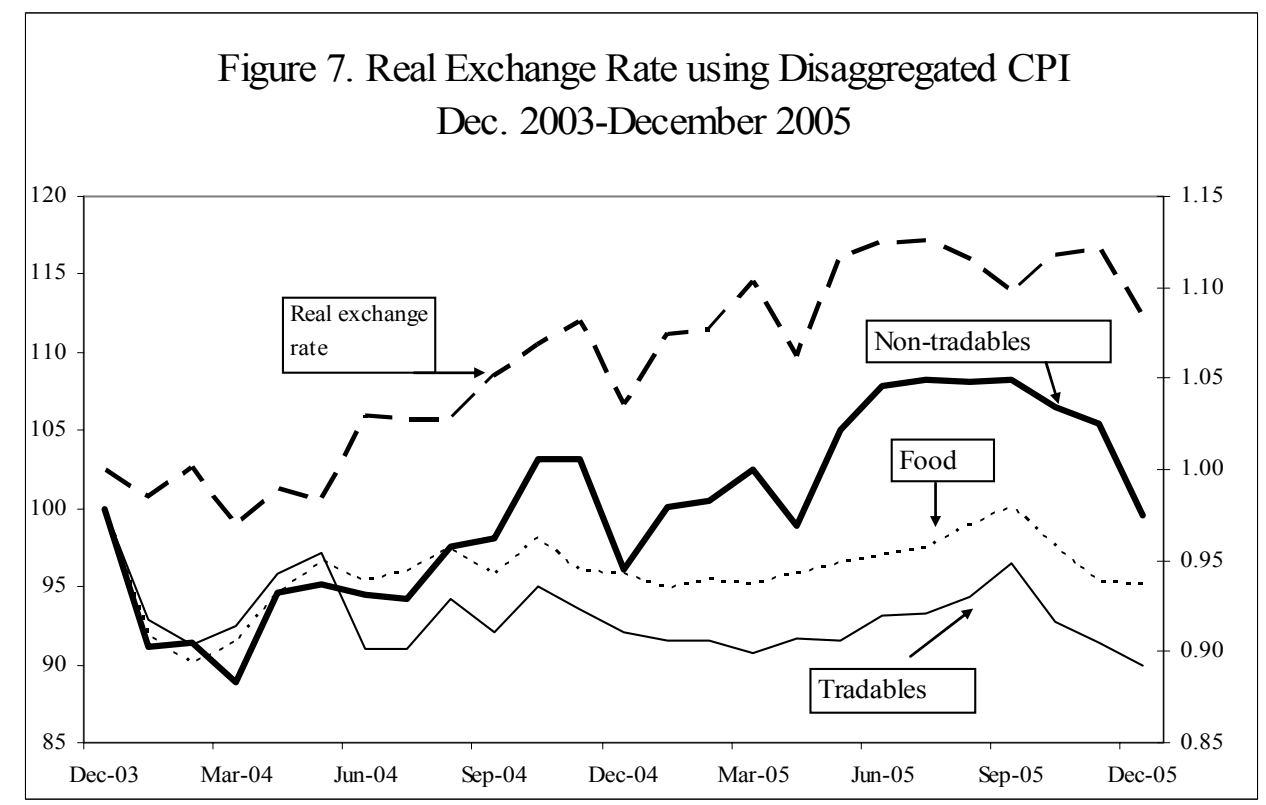

15. Similarly, terms of trade data excluding oil show a sharp drop in the price of exports relative to the price of imports (Figure 8). ${ }^{34}$ This reflects both a strong drop in export prices and a moderate increase in import prices. Since they are combined with nominal exchange rate appreciation, these movements are difficult to interpret, but the drop in export prices could reflect movements in cotton commodity prices.

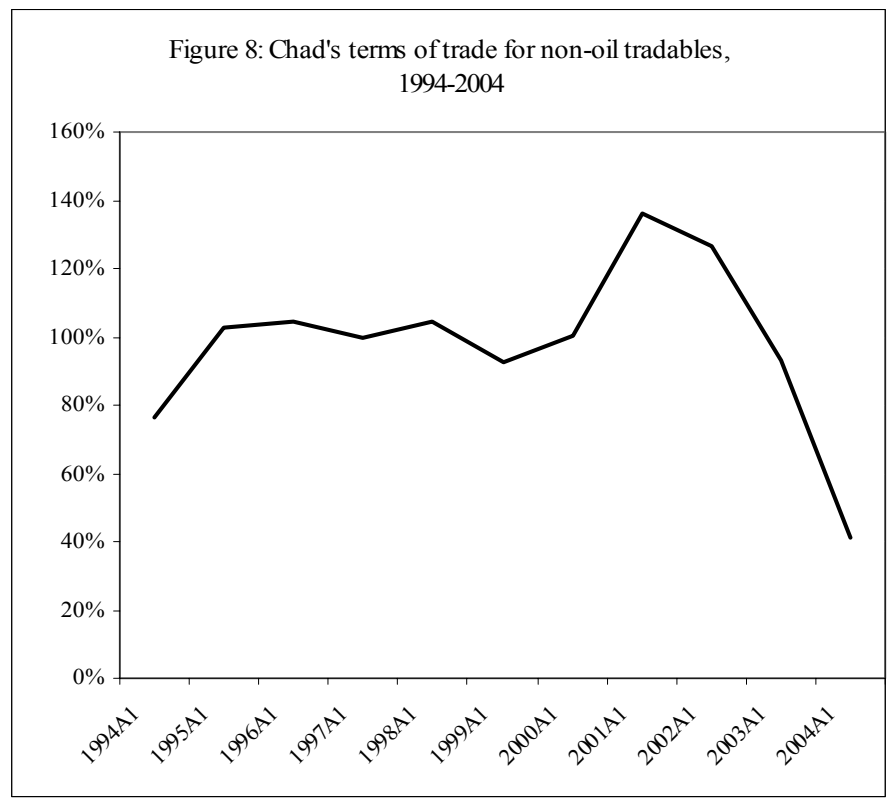

\footnotetext{
${ }^{34}$ The terms of trade data used are from the Fund system. Staff estimates of the terms of trade, based on roughly- imputed price series, do not indicate that non-oil export prices are decreasing relative to non-oil import prices.
} 
16. According to IMF regional surveillance of CEMAC earlier this year, evidence on the evolution of competitiveness in CEMAC members is mixed. ${ }^{35}$ The mission team found that trends in REER differed significantly among members of the monetary union. While in general exchange rate-based measures point to declines in competitiveness, recent increases in export volumes, market penetration ratios, and export market shares of different regions tell a different story. The terms of trade have also improved, mainly because of higher oil prices and increases in export volumes. However, the report does note a slowdown in the growth of non-oil exports, and in view of the limited horizon on Chad's production of oil, the mission recommended a focus on non-oil sector competitiveness. The authorities agreed that expansion in oil sectors had led to growing domestic cost pressures, including higher costs of labor and services particularly in Equatorial Guinea and Chad. But structural rigidities undermine the competitiveness of the non-oil export sector, with business climate indicators showing major obstacles to private sector development for such reasons as limited access to bank credit, high cost of collateral, inadequate legal systems, and labor market rigidities.

17. In terms of Dutch disease, the CEMAC mission noted that heavy reserve inflows were not being adequately sterilized by the regional central bank (BEAC). As a result, the region suffers from substantial excess liquidity and sharp increases in inflation and bank lending in some member countries. The authorities felt in turn that the liquidity situation did not carry a serious threat of inflation.

\section{Possible Policy Responses to Declining Competitiveness}

\section{The government of Chad has not much room to maneuver in making decisions} on an appropriate macroeconomic policy response to the oil windfall. In theory, a loss of competitiveness due to oil sector inflows could be addressed through a variety of policy actions to avoid absorbing the windfall, such as using the foreign exchange to finance higher imports or spending the foreign currency counterpart in the economy. However, the Petroleum Revenue Management Law (PRML) implies in fact that there should be additional spending for investment in priority sectors and dictates that, when absorption capacities are weak, a large share of windfalls in the next few years should be saved. ${ }^{36}$

19. As for absorption, monetary policy is determined by the regional central bank. To the extent the government spends oil revenues domestically according to the PRML, it increases the money supply and sterilization is needed to bring the money supply back in line and avoid igniting inflation. But even the BEAC has few tools for intervention; they consist mainly of reserve requirements and the provision of short-term remunerated deposits for commercial banks. It also must consider the entire CEMAC region. The BEAC is not doing

\footnotetext{
${ }^{35}$ Central African Economic and Monetary Community—Staff Report on Common Policies of Member Countries, Country Report No. 06/317, 6/20/06.

${ }^{36}$ The CEMAC mission advised not to count these resources as official reserves so that they could be invested in longer term assets to generate higher returns.
} 
much to sterilize strong reserve inflows. Moreover, because the CFA franc is pegged to the euro, the nominal exchange rate is exogenously determined and cannot serve as an adjustment mechanism. In theory, if the exchange rate were to float freely, the nominal exchange rate would adjust to compensate for movements in relative prices between countries. If the nominal exchange rate adjusts completely and immediately, real exchange rates would stay in equilibrium, and aggregate purchasing power would be identical in each country.

20. This leaves structural policy as the sole adjustment mechanism. The best way to ensure long-term competitiveness is to increase productivity in the non-oil sector. In fact, the importance of external competitiveness measures is dwarfed by structurally stagnant non-oil productivity in Chad. A recent Diagnostic Trade Integration Study (DTIS) for Chad mentions as potential sectors for further export development cotton, livestock, fishing (Lake Chad), and crops beyond gum arabic, such as spiruline, peanuts, sesame and karite. In addition to meeting the preconditions of macroeconomic stability and durable security, Chad must also overcome numerous obstacles, within the country, outside it, and at the borders, in order to exploit the full growth potential of these sectors. ${ }^{37}$

\section{Perhaps the first priority is to remove obstacles to productivity increases and growth within Chad itself.}

- The lack of basic infrastructure and public services in Chad is extreme. The transport network is woefully inadequate, causing delays and raising transport costs to prohibitive levels. Even in the capital, virtually all roads are made of dirt (deeply-pitted mud in the rainy season). In the rural cotton areas, the roads are often not passable and transport trucks wear out quickly. Because 98 percent of Chadian households do not have access to the electricity grid, they must go without electricity. For those better-off households and businesses that do have access, the grid's capacity is so feeble that they must generate their own backup electricity using high-cost diesel fuel.

- The cotton sector is in a precarious state; the state-owned cotton company is in virtual bankrupt. Serious reform will be needed to keep the cotton sector afloat. While the livestock sector is healthy, its potential for growth is limited because there are formal structures for information-sharing or promotion.

- To foster investment it is imperative that Chad improve the investment climate and governance generally. Chad recently was ranked among the most corrupt countries in Transparency International's list and was near the bottom in terms of being a good place to do business in a recent business climate survey.

22. More efficient customs operations would help productivity in Chad's tradables sector. Problems include ad-hoc exemptions, discretionary application of the rules, and

\footnotetext{
${ }^{37}$ See Cadot et. al
} 
corruption. Also, better data collection on the tradables sector would be useful for measuring improvements.

23. Constraints outside the country are also obstacles to trade. Chad's landlocked status requires exports to pass through Cameroon to the seaport at Douala. Because transit times are long and costly, Chad needs to work closely with other countires in the region to improve these conditions. Also problematic are typical barriers to trade facing developing countries: distortionary cotton subsidies in industrialized countries and entry barriers to world markets, such as high product standards. The best hope for reducing these barriers are the Doha Development Round negotiations and, bilateral agreements, like the European Partnership and the U.S. African Growth and Opportunity Act. The Chadian authorities have signed all the necessary conventions in order to benefit from these initiatives.

\section{Conclusion}

24. Chad's long term competitiveness can only be ensured if it tackles deep-seated obstacles to growth and productivity improvement. Indications that the coming online of oil production may be creating Dutch disease, which will have short- run impacts on the real effective exchange rate, only makes such reforms more imperative. The country has limited means for using the normal policy tools needed to address short-term, with potentially longterm ramifications, oil-induced erosions in competitiveness. 


\section{References}

Burgess, Robert, Fabrizio, Stefania, Xiao, Yuan, 2004, “The Baltics: Competitiveness on the Even of EU Accession," Staff paper, International Monetary Fund.

Cadot, Olivier et al, "Chad: Diagnostic Trade Integration Study," 2005, World Trade Organization Integrated Framework, 6/2/05.

Cashin, Paul, Cespedes, Luis, and Sahay, Ratna, 2002, "Keynes, Cocoa, and Copper: In Search of Commodity Currencies," IMF Working Paper (WP/02/223).

Chen, Yu-chin and Rogoff, Kenneth, 2002, "Commodity Currencies and Empirical Exchange Rate Puzzles,” IMF Working Paper (WP/02/27).

Choudri, Ehsan and Khan, Mohsin, 2004, "Real Exchange Rates in Developing Countries: Are Balassa-Samuelson Effects Present?” IMF Working Paper (WP/04/188).

Clement, Jean, Mueller, Johannes, Cosse, Stephane, and LeDem, Jean, 1996, “Aftermath of the CFA Franc Devaluation," IMF Occasional Paper No. 138, 6/18/96.

Hadjimichael, Michael and Galy, Michel, 1997, "The CFA Franc Zone and the EMU," IMF Working Paper, (WP/97/156).

International Monetary Fund, 2005, “The Macroeconomics of Managing Increased Aid Inflows-Experiences of Low-Income Countries and Policy Implications," August 8, 2005.

International Monetary Fund, 2005, "Central African Economic and Monetary Community-Selected Issues,” (Country Report No. 05/390).

International Monetary Fund, 2005, "Central African Economic and Monetary Community-Recent Developments and Regional Policy Issues," (Country Report No. 05/403).

Krugman, Paul, 1994, “Competitiveness: A Dangerous Obsession,” Foreign Affairs, Vol.73, No. 2.

Loko, Boileau and Tuladhar, Anita, 2005, "Labor Productivity and Real Exchange Rate: The Balassa-Samuelson Disconnect in the former Yugoslav Republic of Macedonia” IMF Working Paper (WP/05/113).

Zanello, Alessandro and Desruelle, Dominique, 1997, "A Primer on the IMF's Information Notice System,” IMF Working Paper (WP/97/71). 


\section{Fiscal Policy and Oil Revenues Management: The Case of Chad ${ }^{38}$}

\section{A. Introduction}

1. Oil revenue offers an unprecedented opportunity for Chad to reduce poverty, but it brings with it serious challenges. The main fiscal challenge is how to guarantee an efficient, transparent, and sustainable use of Chad's short-lived and volatile oil revenue to finance poverty reduction programs, while striking the right balance between spending now and conserving some assets for the future. This paper proposes that Chad adopt a long-term fiscal strategy, nested within a medium-term fiscal framework, and discusses improvements in Chad's institutional fiscal policies that could support the implementation of such a strategy.

2. The main findings of the paper are that

- Chad is among the newest and smallest African oil producers, with a relative small, skewed and finite oil revenue path. Oil revenue is projected to rise from 22 percent of non-oil GDP in 2006 to 31 percent of non-oil GDP in 2007 and then gradually decline to insignificant levels after 2020.

- Chad's World Bank-supported Petroleum Revenue Management Program (PRMP) is an innovative attempt to render transparent the use of oil resources for priority spending. Since its implementation started in 2004, Chad has increased its spending in priority sector and improved transparency of oil revenue despite political instability. However, the PRML (Petroleum Revenue Management Law $)^{39}$ has made heavy claims on Chad's weak administrative capacity and complicated fiscal management. This, and a persistent lack of budget discipline have eroded PRMP efficacy and political acceptance, to the point that in early 2006 the authorities unilaterally modified it.

- Chad's fiscal policy should take on a forward-looking and long-term orientation to avoid stop-go fiscal policies. Reasonable long-term fiscal goals would be the sustainable and gradual transformation of oil wealth into other forms of physical and human capital, reduced budget dependence on oil revenue, and a stronger government's financial position. This could be achieved by implementing medium-term fiscal plans to keep public expenditure in line with absorptive capacity, save some oil revenue to insure future financing of public spending as oil reserves are depleted or prices decline, and increase non-oil revenue.

- A well-defined framework for fiscal policy management could support the implementation of a sound long-term fiscal strategy for Chad. The framework should be based on the principles of fiscal discipline, macroeconomic stability, transparency, best public finance management practices, and enforceability. However,

\footnotetext{
${ }^{38}$ Prepared by Teresa Dabán and Sarah Lacoche.

39 The PRML is the main piece of legislation transposing the PRMP into the Chadian legal system. For more details, see to Annex I.
} 
its effectiveness ultimately would depend on the government's political commitment and society's support for a measured approach to the use of oil revenue.

3. The paper is organized as follows. Section B presents the historical and institutional background of Chad's oil sector. Section C reviews lessons that can be drawn from Chad's experience in managing oil revenue to date. Section D looks at prospects for the oil sector. Section E illustrates, with numerical examples, the challenges Chad faces in designing a viable long-term fiscal strategy. Section F outlines the main pillars of a comprehensive framework for the formulation and implementation of sound fiscal policies in Chad. Section G concludes. Annex I presents the PRMP's legal framework and Annex II presents the results of applying a simplified version of the permanent income hypothesis to Chad.

\section{B. Background}

\section{The oil sector operators}

4. Civil war, political turmoil, and periodic low oil prices have hampered the growth of the Chadian oil sector until 1990s. Chad is home to seven petroleum basins (Doba, Doseo, Salamat, Bongor, Lake Chad, Logone Birni, and Erdis) near the border with the Central African Republic; Doba is so far the only site producing. ${ }^{40}$ Chad began to develop its oil resources as early as 1969. Although exploration wells revealed the existence of oil in 1975, the civil war that began in 1979 stalled exploration in 1981. Exploration resumed soon after the return of peace in early 1990s.

\section{The current oil project began in 1988 when Chad signed a convention with a} consortium of three oil companies. The convention, which permitted exploration until early in 2004, regulated the processes for environmental protection, land acquisition and compensation, and royalties and tax payments. It also granted a 30-year concession to develop and exploit the Doba oil fields and commercialize the oil. Following the discovery in 1996 of up to 1 billion barrels in proven reserves in the Doba basin, the Chadian National Assembly in 1997 enacted an amended convention to regulate exploitation of three oil fields in the Doba basin (Miandoum, Kome, and Bolobo, also known as the "Three-Fields"). Recently, operations have begun in two more fields (Nya and Moundouli) also in the Doba basin, and two additional fields, Maikeri and Timbre, are expected to start producing in 2007 and 2008 respectively. Soaring world prices are spurring explorations in other parts of Chad, although they have not yet yielded economically viable reserves. As in most African countries, Chad's contractual arrangements with oil companies are not made public. ${ }^{41}$

\section{In 1996 Chad and Cameroon signed a treaty to the construction and operation of a pipeline and other oil transportation facilities. Chad has no direct access to the ocean,}

\footnotetext{
${ }^{40}$ Chad also has an estimated 150 million barrels of reserves in the Sedigi field in the Lake Chad Basin, which includes the Kanem and Kumia fields. Development of the Segidi field was planned in conjunction with proposals for a petroleum refinery to fuel a power plant in N'Djamena. The firm in charge built a conduit from Segidi to N'Djamena that is of such poor quality that it is unable to transport oil. As result, accessing Segidi reserves to reduce Chad's domestic petroleum costs have been postponed.

${ }^{41}$ They are only available to a small circle of officials. Some details on the 1988 Convention Agreements can be found in Gary and Reisch (2005).
} 
which is the only practical way to move large quantities of crude oil from the interior of Africa to world markets. Therefore, the government of Chad joined the consortium that set up the Tchad Oil Transportation Company (TOTCO) to build and manage a 1,070 km. underground pipeline with a maximum capacity of 225,000 barrels per day (bdp) to carry oil from the 265 wells in the Doba basin to Kribi on the Atlantic coast of Cameroon. In 1998, Cameroon established the Cameroon Oil Transportation Company (COTCO) to operate its portion of the pipeline. ${ }^{42}$

\section{In 2000, the operating consortium initiated the Chad-Cameroon Petroleum}

\section{Development and Pipeline}

Project, which has an expected

life of 25 to 30 years. This

project - with a total investment of US $\$ 4.2$ billion - is currently the single largest private sector investment in sub-Saharan Africa. It started with the construction of the oil pipeline, which was completed in July 2003, a full year ahead of schedule, and the development of the three fields in the Doba basin, whose production at the time of the project's appraisal, was projected to peak at about 62 millions of barrels per year (bpy) in 2005-2009, decline gradually, and thereafter be

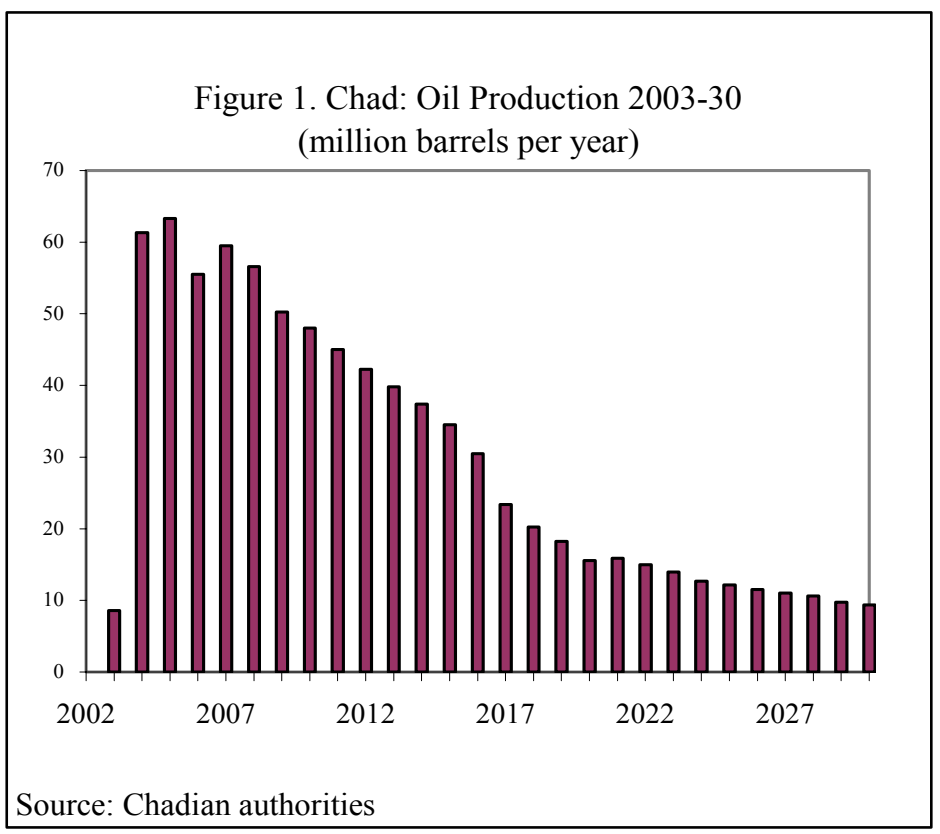
exhausted in 2030.

\section{The Doba crude bears high transportation costs and is treaded at a high} discount in international markets. Transportation costs reflect the operation and maintenance costs and return on investment on the pipeline, commercial debt servicing on the pipeline infrastructure (paid twice a year on a US\$ 600 million loan), and a transit fee of US $\$ 0.41$ per barrel paid to the government of Cameroon. The fact that the heavy and viscous Doba blend oil is high in acid and calcium drives up refinery costs and limits refinery production rates, decreasing the price that refineries are willing to pay compared to competing crudes. $^{43}$

9. Under the current conventions, the government of Chad is entitled to payments of signature bonuses and exploration permits, indirect oil revenue, and direct oil

\footnotetext{
${ }^{42}$ Eighty-five percent of the pipeline is located in Cameroon. Export facilities in Kribi include an onshorepressure reducing station and a subsea pipeline connected to a floating production storage and offloading vessel. ${ }^{43}$ Without sophisticated equipment, a refinery can only turn about one-fourth of a barrel of Chad's Doba oil into high value light products such as gasoline, jet fuel, and diesel. However, at least two-thirds of a Brent barrel of crude oil can be refined into light products. Heavier crude oils like Doba's, are refined into lower value products such as asphalt and bunker oil. See ExxonMobil (2004 a).
} 
revenue. Signature bonuses and exploration permits, which to date have been small, ${ }^{44}$ are upfront payments to the host government when a contract is signed for a concession granting exploration rights and the rental of acreage. Indirect oil revenue comprises the corporate income tax levied on TOTCO and the three oil companies and the personal income tax of TOTCO and oil company employees. Direct oil revenue is defined as dividends paid by TOTCO and COTCO, in which Chad is a shareholder, and royalties paid by the consortium at a 12.5 percent rate. Royalties are calculated on the basis of the average quarterly "implied well-head price," which is equal to the average quarterly Doba sale market price after transportation costs are deducted. The quarterly implied well-head price is approved by the government at the end of each quarter, although with some delays. Provisional payments of royalties are made by consortium members every month based on the last approved quarterly implied well-head price. At the end of each quarter, royalty payments are adjusted through the payment of price settlements to reflect the actual implied well-head price received during that period, which then becomes the provisional price for next quarter.

Box 1. The determination of the "implied well-headed oil price" in Chad

The procedure for determining the "implied well-headed" oil price is defined in the Convention Agreements between the government of Chad and the operating consortium. In accordance with the Conventions, government's approval is required to determine the "implied well-headed" oil price for royalties calculation. The three companies that make up the consortium sell their entitlements independently; they are refining and selling 40 percent of Doba crude themselves. To guard against the possibility that consortium members would sell to their own refineries at below-market prices, the average quarterly sale price submitted to the government is taken from sales to nonconsortium refineries. In theory, government's approval of the quarterly implied well-headed price could take up to three months from the end of the quarter; first, the consortium has up to a month to report to the government the actual implied well-head prices and transportation tariffs applied in the previous quarter; second, the government has another month to revise the reported prices and transport tariffs and request additional information; third, the government has another month to approve the final implied well-head price. In practice, government's approval of the well-head price has taken longer. For example, until the authorities and the oil consortium agreed on a revised implied wellheaded oil price in March 2005, provisional royalty payments were paid using the agreed 2003 well-head price of US $\$ 16.9$ per barrel. Delays continued in 2006: the last price adjustment was made in February.

10. The lack of transparency and unpredictability of tax regime is a source of concern and volatility. The tax regime for the consortium is described in the 1988 Convention Agreement. The convention grants to the consortium members almost full tax exemption from the VAT and custom duties (Hernández Uriz, 2001). ${ }^{45}$ In addition, the government also granted some ad hoc tax credits to the consortium, which were not made available to the public and have given rise recently to a dispute between two of the oil

\footnotetext{
${ }^{44}$ Their use has, however, attracted attention, for example when it was reported in 2000 that the government had spent the first US\$4.5 million of a US\$25 million signing bonus on military spending rather on priority sectors (Gary and Reisch (2005)).

45 The government claims that these tax exemptions only apply to the consortium and its direct oil-related transactions, and not to subcontractors or the consortium's non-oil-related purchases. The consortium's current tax obligations claimed by the government amount to about CFAF 10 billion ( 0.3 percent of non-oil GDP). See ExxonMobil, (2004b).
} 
companies and the government of Chad. ${ }^{46}$ Moreover, information on the tax regime incorporated in the recently agreed conventions to expand exploration beyond the Doba region is scarce. The most important tax payment made so far by the consortium has been the corporate income tax whose rate, under the 1988 Convention Agreement, is a function of oil prices, instead of the general corporate rate of 40 percent. Under the very favorable oil market in 2005 and 2006, the corporate tax rate for the consortium members has increased to 60 percent and given rise to substantial tax payments starting in 2006 . However, this mechanism, which was built into the convention in order to pass much of the benefit of elevated oil prices to the government of Chad (see ExxonMobile, 2006), has also impeded the projections of oil revenue. As regards the personal income tax paid by TOTCO's workers, it amounts only to 0.1 percent of GDP. It is classified as non-oil tax revenue in the fiscal accounts and deposited directly into a Treasury account.

\section{The World Bank's support}

11. Although most of the financing for the Doba oil project came from the private sector, World Bank and International Finance Corporation (IFC) support has been critical to pave the way for private investment. Approximately 97 percent of the project funding came from the consortium and its lenders - 60 percent from the consortium partners and 37 percent from market rate loans arranged through the IFC, export credit agencies, and commercial sources. The other 3 percent represents equity investments in the two pipeline operating companies by the governments of Chad and Cameroon, funded by about US $\$ 140$ million in nonconcessional loans from the World Bank and the European Investment Bank (EIB).

\section{The Bank's support helped mitigate substantial domestic and international} concerns, especially about environmental and governance issues. As a condition for participating in the project, the loan agreement with the World Bank calls for external scrutiny and transparency. First, the External Compliance Monitoring Group (ECMG), which is funded by the oil consortium, monitors compliance with the project's environmental management plan; its reports are made public. Moreover, an International Advisory Group (IAG), independent of the World Bank and composed of "eminent persons" from academia, civil society, and government in Europe, the U.S., and Africa, oversees the adherence by the World Bank, the governments of Chad and Cameroon, and the oil companies to environmental and social safeguards. ${ }^{47}$ Monitoring and transparency have also been promoted by the World Bank's Inspection Panel.

\section{To ensure that oil revenue contributes to reducing poverty in Chad, the Bank conditioned its financial support on a Petroleum Revenue Management Program}

\footnotetext{
${ }^{46}$ In mid 2006 two of the oil companies disputed the payment of the income taxe corresponding to their 2005 profits from their operation on the Doba Three-Fields on the base of an alleged tax credit granted in 2000 by the authorities. The authorities claimed that the alleged tax credit was not valid as it was granted by the thenMinister of Petroleum acting beyond his authority. After several months of negotiations the two oil companies finally agreed to pay their income tax, which amounted to about 8 percent of non-oil GDP.

47 The IAG makes regular field visits and reports directly to the World Bank president and the public. Its function is purely diagnostic and advisory; it has no authority to implement its recommendations. See $\underline{w w w . g i c-}$ iag.org.
} 
(PRMP). The PRMP includes provisions to (i) smooth oil-funded spending by stabilizing excess oil revenue and accumulate savings in a Fund for the Future Generations (FFG); (ii) allocate most oil revenue to increase priority spending in health, social welfare, education, infrastructure, energy, rural development, environment, and water resources above the pre-oil era budget allocations; (iii) promote the implementation of medium-term expenditure frameworks (MTEF) linked to the government's Poverty Reduction Strategy Paper (PRSP); and (iv) establish oversight mechanisms.

\section{The Petroleum Revenue Management Program}

\section{A separate banking procedure in the PRMP calls for specific accounts for each} category of operations (Figure 2). It stipulates that a transit account opened in the name of the government of Chad with an international bank should be used first to collect direct oil revenue (royalties and dividends) and indirect oil revenue (mostly taxes) from the three fields in the Doba region. All interest and investment returns on the funds deposited at the international bank are also credited to this account. After the bank's management fees are deducted, oil revenue should be transferred to an escrow account and used to provision payments due on loans from the World Bank and the EIB. After provision for debt service, indirect oil revenue can be directly transferred to a Treasury account, and 10 percent of direct oil revenue should be deposited in an off-shore savings account at the same international bank for the FFG. The rest of direct oil revenue should be deposited in an account at the Bank for the Central African States (BEAC) after a one-day transit through accounts opened in two domestic commercial banks, which deduct a commission amounting to 0.15 percent of the transferred funds.

\section{The PRMP also sets out mechanisms to ensure the transparent allocation of oil} royalties and dividends to priority spending. It stipulates that direct oil revenue should be allocated as follows: 72 percent of royalties and 76.5 percent of dividends should be deposited in a stabilization account and transferred to accounts opened in domestic commercial banks to be used exclusively for priority sector programs; 13.5 percent of dividends and royalties should be allocated to the ordinary budget and deposited in the Treasury account at the BEAC; and, 4.5 percent of royalties should go into a separate account for the oil producing region. The PRMP also provides for a joint government/civil society, and autonomous Collegiums of Control and Surveillance (the Collège) to authorize and monitor the use of direct oil revenue. To strengthen Chad's institutional capacity and contribute to successful implementation of the PRMP, the World Bank supported two technical assistance projects: the Management of the Petroleum Economy project and the Petroleum Sector Management Capacity Building Project. 
Figure 2. Distribution of Oil Revenue in Chad according to the Petroleum Revenue Management Program

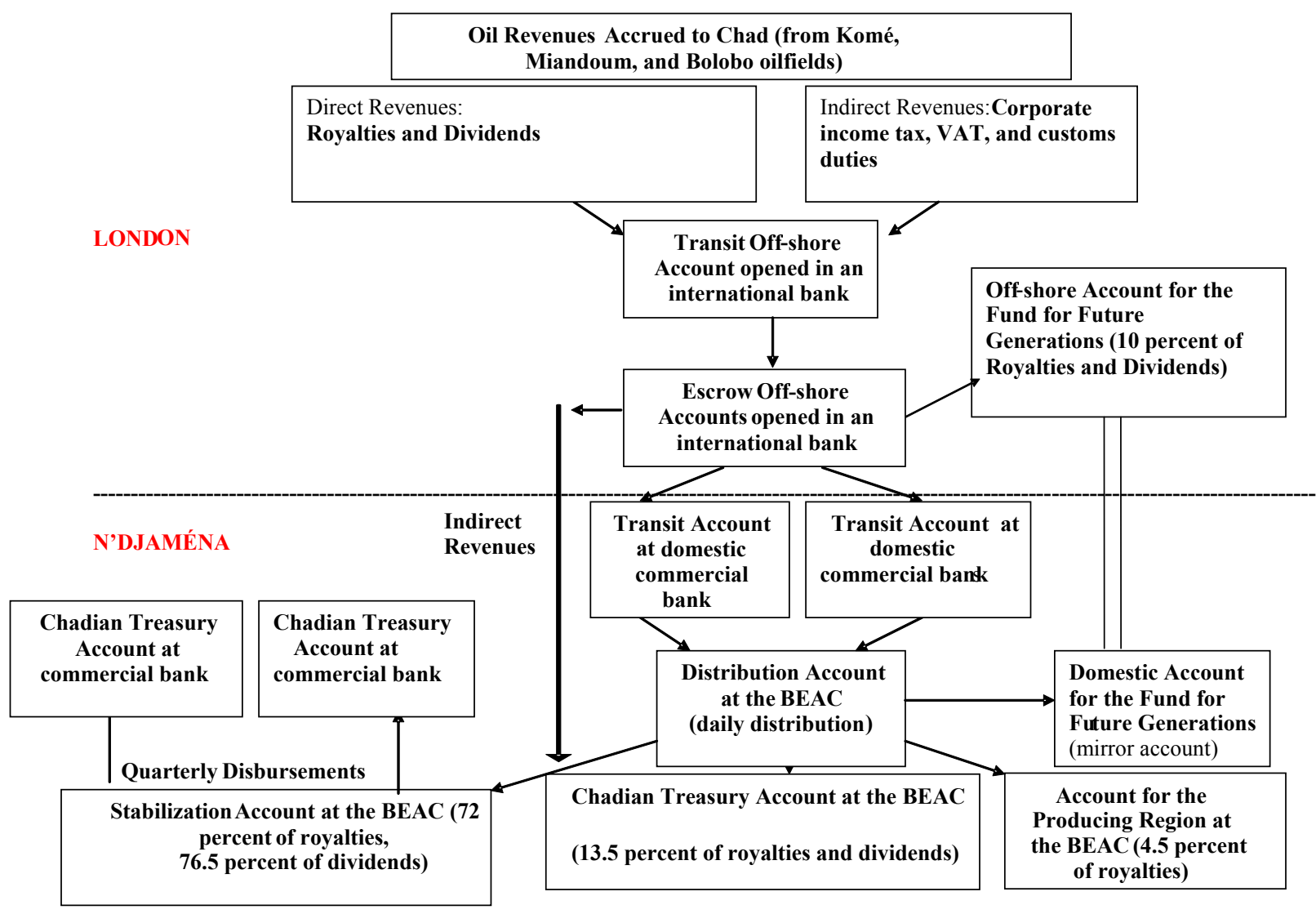

16. In compliance with the loan agreement, the government of Chad enshrined the PRMP in the 1999 Petroleum Revenue Management Law (PRML) and related decrees issued in 2003 and 2004 (Annex I). The PRML's legal framework contains additional provisions: the additionality provision mandates that 42.6 percent of the ordinary budget, which is partially funded with 13.5 percent of direct oil revenue, must be allocated to priority spending (to ensure additionality of the oil-funded spending compared to the 2002 budget allocations); the inter-generational equity provision mandates that deposits for the FFG may only be withdrawn if oil revenue is less than or equal to 10 percent of total government revenue for the preceding year, and in an amount that cannot exceed total funds deposited in the FFG for the preceding year; the stabilization provision mandates that all direct oil revenue in excess of budgeted (forecasted) revenue will be deposited in a "sterilization fund" that could be used if actual oil revenue fall below planned revenue by up to 20 percent. If the difference exceeds 20 percent, the budget must be revised. If the situation lasts for more than three months, the government must revise the macroeconomic framework.

\section{Early in 2006, the authorities unilaterally modified the PRML, breaching} agreements with the World Bank and the EIB. They justified abolishing the FFG on the grounds of higher long-term yields from investments to meet Chad's high present needs; moreover, the growing balances in the FFG were largely offset in 2004 and 2005 by increasing domestic borrowing and arrears. They also argued that the list of priority sectors needed to be expanded to include security-related priorities identified by the 2003 PRSP, 
such as police and gendarmerie, demining, territorial administration, and the judiciary. Moreover, they justified an increase from 13.5 percent to 30 percent in the share of nonearmarked oil revenue by the need to facilitate execution of the ordinary budget as budget support declined and new expenditure needs arose. Last, they revised the PRML to cover all Chad's oil fields. The Bank responded by suspending most Bank operations and freezing the government's oil escrow account.

\section{After several months of discussion, the resolution of the dispute between Chad} and the World Bank opened the way for a new more comprehensive approach to oil revenue management. The April interim agreement focused on the use of oil revenue to finance increased priority spending in a revised 2006 budget and on measures to strengthen public finance management and oversight (the PAMFIP). ${ }^{48}$ The Memorandum of Understanding (MOU) reached on July 13, which lifted all contractual remedies and will be in place until the formulation of a new PRML, contains the following main provisions: (i) all oil revenue, not simply oil royalties and dividends, will be considered to finance Chad's poverty-reduction strategy; (ii) spending will be limited to Chad's absorptive capacity and excess oil revenue saved under a mechanism that will be put in place by the end of 2006; (iii) at least 70 percent of total budget resources will be allocated to agreed-upon priority sectors; (iv) the list of priority sectors is expanded to include land-mine removal and good governance including justice and anti-corruption; (v) the Collège will be provided with additional support and resources; and (vi) the 5 percent for development in the Doba region will remain in effect. The MOU also establishes that the list of priority sectors, as well as the design of a new PRMP, will be revised at the time of the PRSP update in late 2007.

\footnotetext{
${ }^{48}$ It refers to the government's Plan d'Action pour la Modernization des Finances Publiques (PAMFIP).
} 


\section{Lessons from PRMP Implementation in Chad}

19. Under the PRMP

implementation period, the share of priority spending in the budget increased and the transparency of oil revenue improved. Oil almost doubled government revenue, from 9 percent of non-oil GDP in 2003 to 17 percent in 2005 . Primary current expenditure rose from 10 percent of non-oil GDP to 11 percent, and domestically financed investment from 2 percent of non-oil GDP to 4 percent, resulting in an increase of 3 percent of non-oil GDP in the non-oil primary deficit. Information on oil revenue is published routinely; the Collège publishes quarterly reports on the execution of oil-financed programs. In 2006, due to the deterioration of the security situation, exceptional military spending are estimated at 4.3 percent of non-oil GDP. However, priority sector expenditure is expected to increase by about 70 percent in nominal terms.

20. However, reflecting poor budget discipline and weak administrative capacity, actual priority sector spending, and its monitoring, have fallen short of expectations. Although allocations in the ordinary budget have been increased as stipulated by the additionality provisions, actual priority spending has accounted for less than the required 42.6 percent of expenditure in the ordinary budget. Under mounting cash-flow constraints in 2005 , the government borrowed from oil budget accounts to finance the ordinary budget through loans from the stabilization account and "VAT advances" on future oil-financed procurement contracts that are collateralized by oil receipts. As a result, because fewer oil budget resources were available, oil-financed priority spending (mainly capital outlays) was lower than intended. This illustrates the limitations on the Collège's ability to resist government's pressure to circumvent the earmarking framework when social tensions arise. Moreover, execution of priority spending has been also hindered by procurement irregularities - a lack of competitive bidding and overpriced goods and services. Though the Collège highlighted these irregularities in its 2004 report, the government failed to address them, demonstrating the weaknesses in controls.

21. The PRMP experience shows the importance of designing frameworks that have comprehensive coverage. A significant share of oil revenue falls outside PRMP jurisdiction and oversight mechanisms. Strictly speaking the PRMP only covers the Three-Fields in the Doba region, although in practice the government has extended the PRMP application to the new satellite fields. In addition, the PRMP did not refer to certain oil-related revenue, such as 
exploration permits and signatures bonuses; moreover, the main PRMP principles apply only to direct oil revenue, not to indirect oil revenue. Furthermore, because the PRML's does not recognize the PRMP's obligation to deposit all oil revenue into the off-shore oil escrow account, oil income taxes are at present deposited directly into treasury accounts.

\section{The PRMP complexity has laid a heavy burden on Chad's weak administrative} capacity that has hampered transparency and accountability. The complex separated banking procedures for oil revenue and the rigid earmarking mechanisms have hampered the integrated management of the government's budget, assets, and cash operations. Budget execution system was not well adapted to monitor this fragmented system and the Collège has focused on monitoring ex-ante spending authorizations rather the execution of priority sector spending.

\section{The implementation of the PRMP's long-term saving and stabilization} mechanisms has also posed important challenges. The absence of provisions to run regularly fiscal sustainability analysis has hampered the assessment of the FFG, which, under rigid CEMAC rules and the lack of an alternative investment strategy, has failed to generate a market-based remuneration as to compensate for the increased government borrowing costs and the foregone social returns of well-selected development projects. The PRML's provisions for the elaboration of MTEFs to frame the elaboration of annual budget laws are very vague and have not been implemented; there was no oil revenue account for stabilization purposes (the stabilization account was also used to finance spending for priority sectors) and no oil revenue was stabilized in 2003-05; although never applied, the automatic authorization to withdraw from the oil accounts if the short-fall in oil revenue is below 20 percent, implies strong incentives to overestimate revenue.

\section{Poor planning and design are also apparent in terms of the allocation} percentage for the producing region. There is not justification neither any targeted study for the determination of the 5 percent of royalties (net of debt service and FFG) assigned to the Doba's region. In addition, as the PRML allows the alteration by decree of this percentage, Chad risks to experience a reduction in the amount of oil revenue allocated to the producing region. In absence of a comprehensive map of local needs and priorities, the recently finished development plan remains unclear about the principles that will guide the use of the oil revenue ear-marked to the oil-producing region. ${ }^{49}$

\section{Chad's Oil Sector Developments and Prospects}

Chad is among the newest and smallest African oil-producing countries (Box 2) and its oil production is expected to be very short-lived. Some countries, like Angola and Nigeria, have been producing significant amounts of oil for decades and are expected to continue doing so for a considerable time. Others, like Cameroon, are nearing the end of their oil

\footnotetext{
${ }^{49}$ On September 2, 2004, the government of Chad issued a decree proposing the creation of an interim committee to manage the use of oil revenues in the producing region. However, the committee is not yet functional.
} 
booms. Chad only began producing oil in July $2003 ;{ }^{50}$ its production is comparatively small for an African oil state and it is not expected to last long. Nonetheless, Chad's economy is dominated by the oil sector, which in 2005 accounted for over 40 percent of GDP at current prices, about 50 percent of government revenue (excluding grants), and almost 80 percent of merchandise exports.

\section{Box 2. The Oil Sector in Chad in Regional Perspective}

Chad's oil production is the lowest among African oil producers, except for Cameroon, where production has been declining since 1991. Also, as in the case of Cameroon and Congo, Chad's oil is traded on the international markets at a heavy discount.

Like other African oil producers, Chad has had to attract foreign direct investment to develop its oil deposits, given the high technological and financial requirements and risks involved. Like other African countries, Chad has not made its contractual arrangements with foreign oil companies available to the public.

Unlike many other African countries, where production-sharing contracts (PSA) are the standard operating procedure, Chad mostly uses a concession contract system. In a PSA foreign oil companies act as a contractor for the government, finance all investment costs, recoup the investment with "cost oil," and share "profit oil" with the government. Under a PSA, governments usually sell their shares of oil on the international markets through national oil companies or traders or sell directly to the foreign oil company. Chad, which as yet has no national oil company so far, allows the production consortium to sell on the international market and derives revenue mostly from royalties and income tax. The National Assembly approved in mid-2006 a law for the creation of a National Oil Company, but no step has been taken so far for its creation. New agreements for exploration outside the Doba region also envisaged payments in oil.

Oil sector in Sub-Saharan Africa 2005-10

\begin{tabular}{|c|c|c|c|c|c|c|c|c|}
\hline & Angola & Cameroon & Chad & Congo & $\begin{array}{l}\text { Equat. } \\
\text { Guinea }\end{array}$ & Gabon & Nigeria & $\begin{array}{c}\text { SSA } \\
\text { Average }\end{array}$ \\
\hline Oil production (million of barrels per year) & 692.2 & 28.3 & 56.0 & 105.4 & 143.4 & 94.7 & 964.7 & 297.8 \\
\hline Oil production/Total GDP (percent) & 76.8 & 6.0 & 38.1 & 77.7 & 98.3 & 48.5 & 46.3 & 55.9 \\
\hline Oil exports/total exports (percent) & 92.3 & 25.2 & 72.1 & 97.5 & 99.8 & 78.0 & 80.3 & 77.9 \\
\hline Oil Revenue/Total GDP (percent) & 33.7 & 3.9 & 9.0 & 35.0 & 32.5 & 17.3 & 40.0 & 24.5 \\
\hline Oil revenue/Total revenue (percent) & 79.9 & 22.3 & 52.0 & 96.7 & 90.9 & 81.6 & 79.9 & 71.9 \\
\hline Government Oil Revenue/Oil Export (percent) & 43.1 & 64.1 & 22.3 & 42.7 & 31.6 & 34.9 & 90.1 & 47.0 \\
\hline
\end{tabular}

Sources:Chadian authorities, and IMF oil data base.

\footnotetext{
${ }^{50}$ Although the first sales on international markets were in October 2003, as the first oil was used to fill the pipeline, for which royalties are not due until production ceases. The first royalty payment was due in October 2003, but no oil revenue was transferred to Chad until July 2004 because of delays in finalizing contracts between the government and the BEAC on setting up the stabilization and oil-producing region accounts.
} 
25. Chad's oil production has proven difficult to project. Initial projections were for oil production to increase steadily from the 18,000 barrels per day (bpd) produced in July 2003 to 225,000 bpd by 2004 and plateau there through 2009 (Figure 4). In late 2004 oil production did reach the 225,000 bpd maximum capacity of the pipeline, and total annual production totaled 61 million barrels (Table 1). However, early in 2005, unexpected problems with the porosity of the subsoil led to excessive mixing of water with the oil deposits. The need to separate out the water reduced Doba oil production from 225,000 bpd in December 2004 to around 164,000 bpd in June 2005. Application of reinjection techniques to increase the yield of the Doba fields and the coming on-line of new two oil fields (Nya and Moundouli) helped to maintain oil production at around 173,000 bpd in 2005, though it is likely to be reduced to 152,000 bpd in 2006 and 138,000 bpd through 2009, despite the expected coming on stream of two new satellite fields (Maikeri and Timbre). The three main Doba fields (Miandoum, Kome, and Bolobo) are expected to be depleted by the early 2030s.

26. Uncertainty over oil prices facing Chad is amplified by the volatility in the discount with respect to Brent crude and transportation costs. In early projections, the discount and transportation cost were projected to stay at about US $\$ 10$ per barrel $(\mathrm{pb})$ over the medium term (Table 1). ${ }^{51}$ In 2004 markets forces pushed the discount up to US $\$ 14 \mathrm{pb}$ as refineries tended to choose light crude over heavy in a context of high demand for light refined petroleum products. The unexpectedly low volume of production also increased $\mathrm{pb}$ transportation costs. However, late in 2005 the discount narrowed to about US\$9 pb in the expectation of rising demand for heating fuel (heavy) during the peak-demand northern hemisphere winter; a slow recovery of production of other heavy oils in the Gulf of Mexico; and the fact that the Doba blend is becoming better known in international markets (Figure 5). Over the medium term, characteristics of the Doba blend are expected to improve slightly with production from the Moundouli field; the discount and the transportation cost are expected both to hold steady at about US $\$ 8$ over the medium-term.

\footnotetext{
${ }^{51}$ The discount was projected about US $\$ 10$ a barrel, although early shipments commanded a relatively lower discount (about US\$2 per barrel) because at first the consortium shipped oil only from the Miandoum field, which contains the lightest oil in the Doba area.
} 


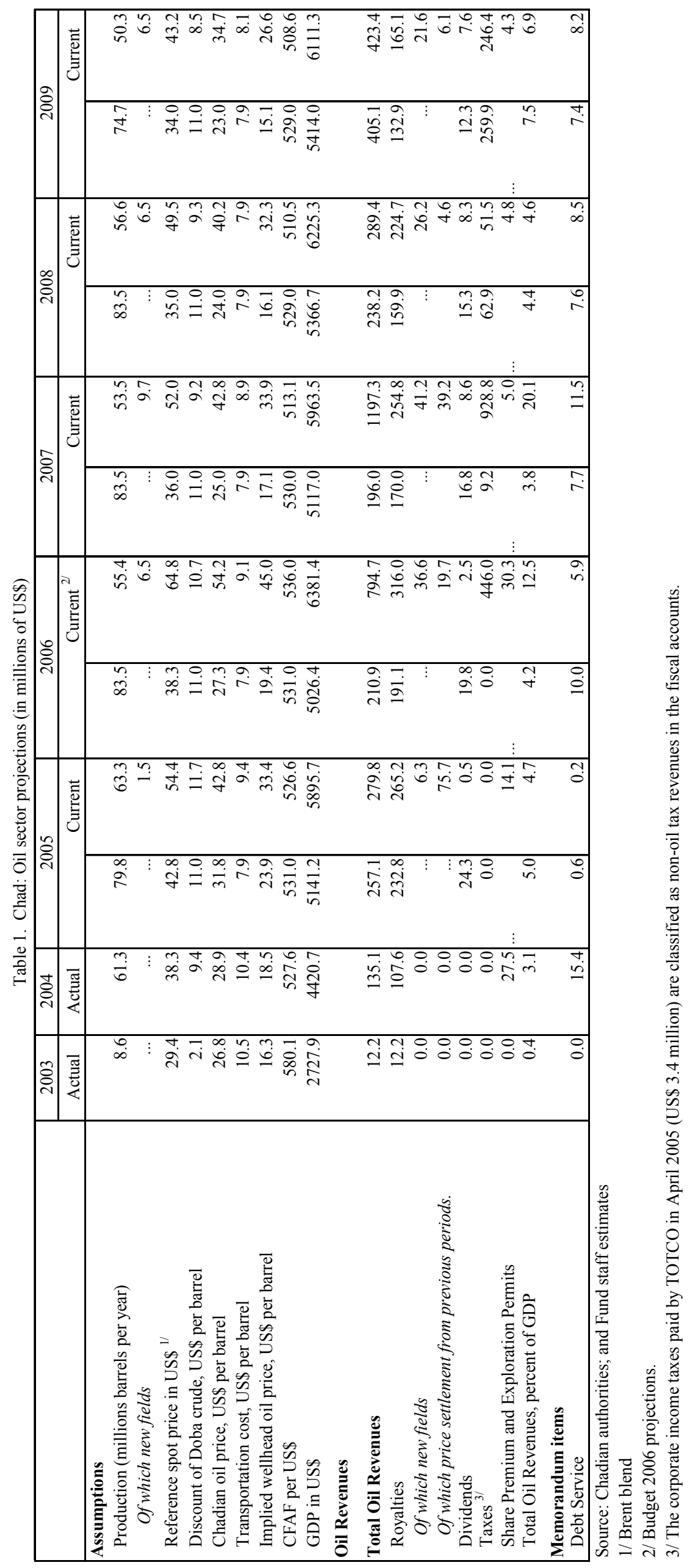


Figure 4. Chad: Monthly Oil Production July 2003-December 2009

(thousand of barrels per day)

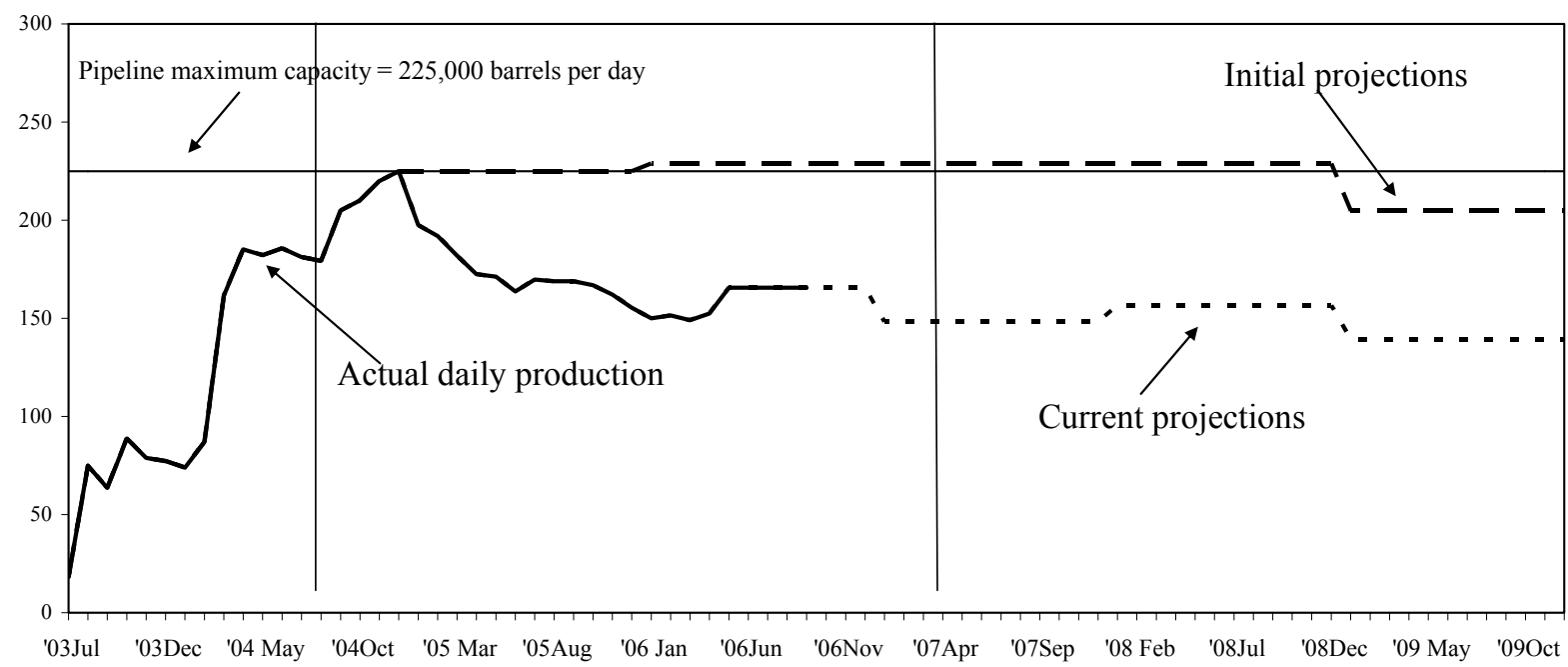

Figure 5. Chad: Monthly Doba and Well-Head Oil Price October 2003-December 2009 (in US\$ per barrel)

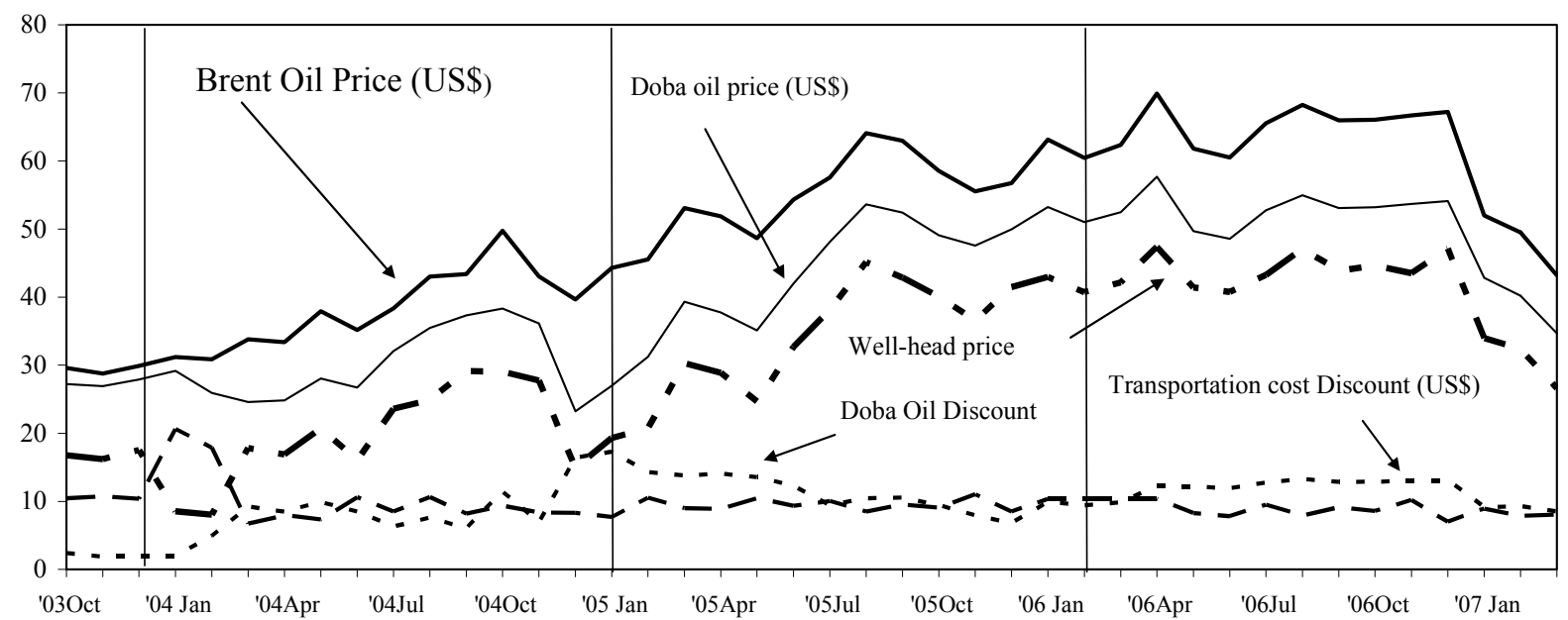

27. The revenue impact of the reduced production will be more than offset by oil prices that are about twice as high as were projected. Under the implied well-head price per barrel assumed in early projections and given high initial investments, oil income taxes were not expected until well after 2009. However, in early 2006 oil companies confirmed that the high well-head price, which reached US\$33 a barrel in 2005, allowed them to recover part of the upstream investment. As a result, in 2006 oil companies are expected to pay income tax equivalent of about 13 percent of non-oil GDP on 2005 profits, part of which was already paid on March 31, plus an equal advance on 2006 income tax, paid in equal quarterly installments (Table 2). 
Table 2. Chad: Income Tax of the Oil Sector

\begin{tabular}{|c|c|c|c|c|}
\hline & 2006 & 2007 & 2008 & 2009 \\
\hline & \multicolumn{4}{|c|}{ (In millions of US\$) } \\
\hline Total Income Tax & 446.0 & 938.7 & 54.5 & 247.6 \\
\hline Consortium & 435.3 & 936.6 & 54.0 & 243.6 \\
\hline Annual filing ${ }^{1}$ & 217.6 & 577.2 & 315.6 & 279.6 \\
\hline Advances payment $^{2}$ & 217.7 & 577.2 & 315.6 & 279.6 \\
\hline Advance payment of previous year & & -217.7 & -577.2 & -315.6 \\
\hline тотсо & 10.6 & 2.1 & 0.5 & 4.0 \\
\hline Annual filing ${ }^{1}$ & 7.0 & 2.9 & 1.7 & 2.8 \\
\hline Advances payment ${ }^{2}$ & 3.6 & 2.9 & 1.7 & 2.8 \\
\hline Advance payment of previous year & $\ldots$ & -3.6 & -2.9 & -1.7 \\
\hline Brent oil price (US\$ per barrel) & 64.8 & 52.0 & 49.5 & 43.2 \\
\hline Oil production (billion barrel per year) & 57.1 & 53.5 & 56.6 & 50.3 \\
\hline
\end{tabular}

Source: Chadian authorities; oil consortium, and Fund staff estimates

$1 /$ About 60 percent of previous-year taxable profit.

2/ Paid as quarterly installments in March, June, September, and December, in the case of

the consortium and on three installments in the case of TOTCO.

28. Over the medium-term, total oil revenue is expected to increase sharply in 2007 , before falling in 2008-09. In 2007 oil revenue will reflect: (a) high income taxes on 2006 profits and the corresponding advance; and (b) a relatively low deduction on account of the advance paid in 2006. Assuming a moderate decline in production and a reduction in oil prices, ${ }^{52}$ oil companies' profits will decline in 2008-09. This will lead to a decline in oil royalties and dividends, and a more accentuated decline in net income tax payments, reflecting the regularization of the advances on income tax paid in previous years. Consequently, starting in 2008, oil revenue would cease contributing significantly to government

Figure 6: Chad: Oil revenue 2003-09 (Percent of non-oil GDP)

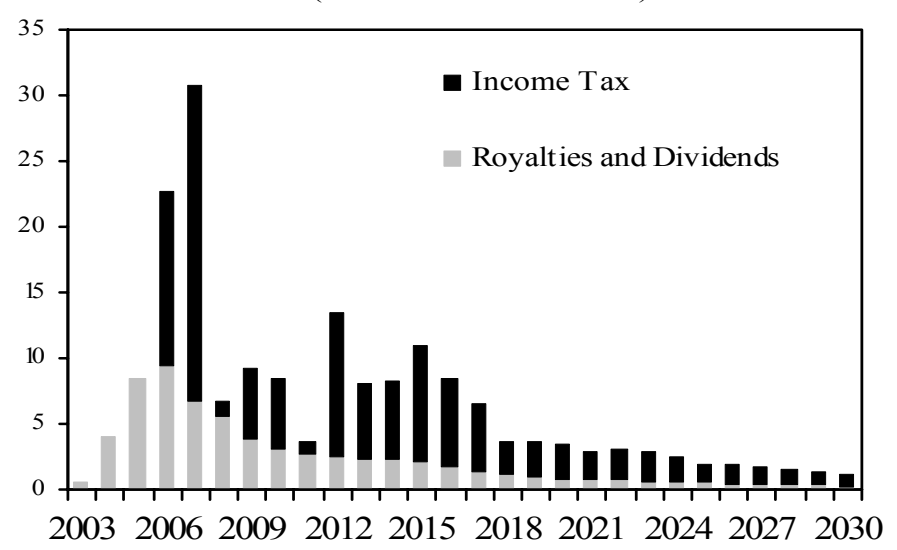
revenue (Figure 6).

29. Over the long-term, after a slight recovery around 2015 , oil revenue will decline to insignificant levels by 2030. Oil production is expected to decline from 59 million barrels in 2009 to about 30 million barrels in 2015 and remain around 15-10 million barrels afterwards, before the complete depletion of the fields by 2030. On the basis of prudent oil prices projections, which assume that the Brent oil prices would remain constant in real terms over 2009-30, oil revenue is

\footnotetext{
${ }^{52}$ Oil revenue projections are in line with the updated Level I scenario of the Government Petroleum Revenue Forecast for 2006-33 prepared jointly by the World Bnak and the authorities, which were updated in early October 2006. The baseline oil price projection remains cautious, with an average well-head price of US\$29 pb for 2007-09 that is roughly US $\$ 17 \mathrm{pb}$ lower than the implied well-head price based on current WEO projections.
} 
expected to recover slightly around 2012, reflecting the expected reduction in the transportation cost, before declining to below 1 percent of non-oil GDP in 2030. (Figure 7).

Figure 7. Chad: Doba and Well-Head Oil Price 2003-2030

(in US\$ per barrel)

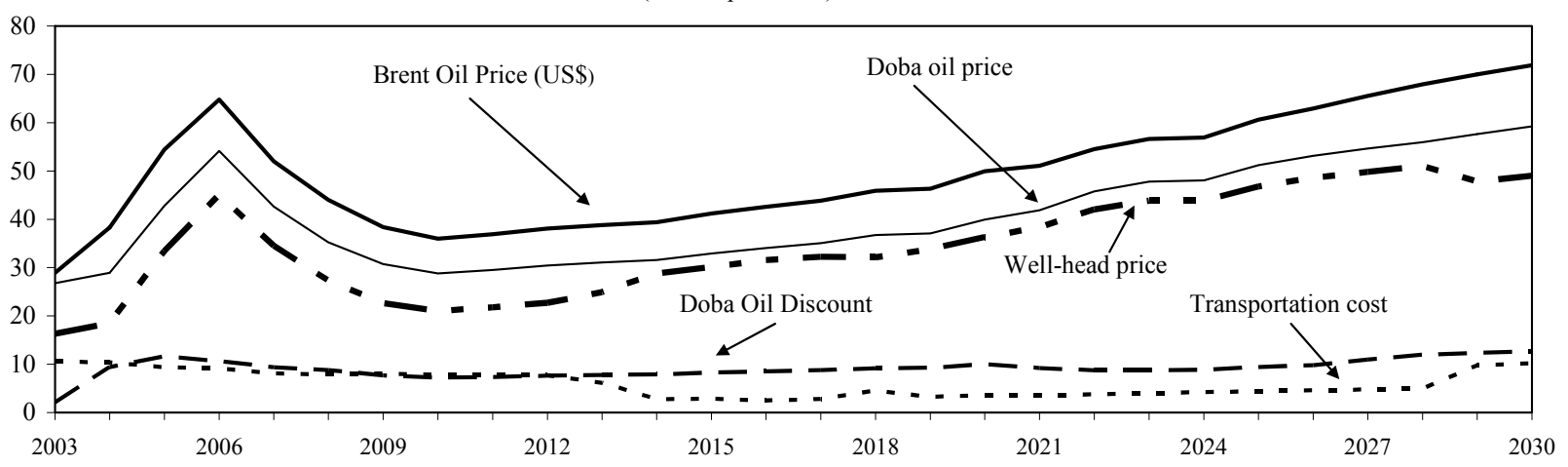

30. Chad's oil sector perspectives hinge on the results of the ongoing negotiations of the oil convention and the creation of a National Oil Company (NOC). The establishment of the NOC was approved by the National Assembly in August 2006 and followed by the nomination of a committee to renegotiate the 1998 Convention Agreements on oil production, with a view to introducing production-sharing arrangements between the NOC and the existing consortium, and also in line with new agreements for exploration outside the Doba region, which also envisage payments in oil. The creation of a NOC in Chad is difficult to justify, given the limited time horizon for oil production, capacity constraints, meager financial resources, and problems in managing other public enterprises. To pursue legitimate objectives, such as acquisition of sector-specific techniques, and management skills, Chad should use other means.

\section{E. Long-term Fiscal Strategy Options for Chad}

31. Chad's primary long-term challenge is to strike the right balance between spending some of the oil windfall and conserving some for the future. This decision involves trade-offs. For example, addressing poverty and infrastructure needs quickly may alleviate poverty in the short run and contribute to foster non-oil GDP but may undermine macroeconomic stability, damage the long-term growth potential of the non-oil sector, and give rise to waste given Chad's low administrative capacity. In addition, a high frontloaded expenditure profile would not allow the government to build a buffer of oil deposits that could be used in case of a shortfall in oil revenue or to finance the budget when oil production is exhausted. However, saving oil revenue for the future or for precautionary reasons will require a strong political will and civil consensus to fend off pressures to increase spending. It could be hard to justify in the face of undeniable substantial needs.

32. Separating this decision into a two-step process reduces its complexity. In the first step, the government would design a long-term fiscal strategy to transform oil wealth into other forms of capital, while conserving some for future fiscal years. It should also reduce the exposure of the budget to oil revenue changes and ensure a sound fiscal position when oil revenue fall off. The long-term strategy would determine the size and path of the non-oil primary deficit based on purely long-term considerations, including targets for non-oil revenue, expenditure, and net financial 
wealth. In the second step, the government would design medium-term fiscal plans based on the long-term fiscal strategy, setting medium-term targets for expenditure and non-oil revenue. A viable fiscal strategy for Chad, as outlined in Table 3, would respond to both medium-term and long-term considerations.

Table 3. The Design of a Long-Term Fiscal Strategy for Chad

\begin{tabular}{|c|c|c|}
\hline \multicolumn{3}{|c|}{ First Step: Design of a Long-Term Fiscal Policy } \\
\hline Final Goals & Intermediary Objectives & Long-Term Indicative Targets \\
\hline $\begin{array}{l}\text { Transform oil wealth into } \\
\text { other forms of physical, } \\
\text { human and financial capital. } \\
\text { - Reduce the budget's } \\
\text { exposure to oil revenue. } \\
\text { - Map a declining path for } \\
\text { the NPV of debt. } \\
\text { - Achieve a sound fiscal } \\
\text { and financial position. }\end{array}$ & $\begin{array}{l}\text { - Increasing non-oil tax } \\
\text { revenue collection up about the } \\
\text { level of neighboring countries. } \\
\text { - Keep the non-oil primary } \\
\text { deficit financeable. } \\
\text { - Avoid both domestic and } \\
\text { foreign borrowing by using oil } \\
\text { revenue as the main financing } \\
\text { source for the budget as long as } \\
\text { possible. }\end{array}$ & $\begin{array}{l}\text { - Non-oil revenue ratio of about } \\
16 \text { percent of non-oil GDP (average } \\
\text { for CEMAC countries). } \\
\text { - Non-oil primary balance with a } \\
\text { surplus covering debt service } \\
\text { payments. } \\
\text { - Domestically financed primary } \\
\text { expenditure of about } 17 \text { percent of } \\
\text { non-oil GDP on average. } \\
\text { - New borrowing to finance the } \\
\text { budget limited to concessional } \\
\text { borrowing and in line with } \\
\text { sustainable set of debt sustainability } \\
\text { indicators; the NPV of outstanding } \\
\text { debt would decline. }\end{array}$ \\
\hline \multicolumn{3}{|c|}{ Second Step: Design of Medium-Term Fiscal Plans } \\
\hline Final Goals & Intermediary Objectives & Medium-Term Indicative Targets \\
\hline $\begin{array}{l}\text { - Keep expenditure in line } \\
\text { with administrative capacity } \\
\text { and macroeconomic stability. } \\
\text { - Avoid procyclical fiscal } \\
\text { policy and large fluctuations } \\
\text { in non-oil primary deficit. } \\
\text { - Improve non-oil tax } \\
\text { collections. }\end{array}$ & $\begin{array}{l}\text { - Adopt medium-term plans to } \\
\text { increase non-oil tax collection. } \\
\text { - Avoid public expenditure } \\
\text { increases when oil prices rise to } \\
\text { prevent abrupt cuts in spending } \\
\text { when oil prices fall. } \\
\text { - Create a liquidity cushion to } \\
\text { prevent credit constraints. } \\
\text { - Maintain a balance between } \\
\text { current and investment spending }\end{array}$ & $\begin{array}{l}\text { - Realistic non-oil tax ratio } \\
\text { increase (e.g. } 1 \text { percent of non-oil } \\
\text { GDP over a three-year period). } \\
\text { - Gradual improvement of non-oil } \\
\text { primary deficit (e.g. by } 3 \text { percent of } \\
\text { non-oil GDP over a three-year } \\
\text { period, excluding exceptional one- } \\
\text { off spending). } \\
\text { - Gradual adjustment of } \\
\text { domestically financed expenditure } \\
\text { (e.g. by } 1 \text { or } 2 \text { percent of non-oil } \\
\text { GDP over a three-year period). }\end{array}$ \\
\hline
\end{tabular}




\section{First Step: The Long-Term Fiscal Strategy}

\section{One option to determine the long-term fiscal path could be the Permanent Income} Hypothesis (PIH), which given Chad's small and short-lived oil production, would lead to a too low sustainable non-oil primary deficit. The PIH has been adopted by several countries. ${ }^{53}$ Under this policy rule the government would use in fiscal year $t$ only the sustainable (permanent) annual income, which is the maximum amount that can be appropriated from oil savings in that fiscal year and still leave enough savings for an amount equal to the real value to be appropriated in all later fiscal years (see Annex II). However, given that unmet social needs and absorptive capacity considerations are not taken into account in the calculation of the standard sustainable income, the resulting level of primary expenditure under the PIH could need to be adjusted to the country's specific features. For instance, in the case of Saõ Tomé and Príncipe, applying the PIH gives rise to an expenditure path that is well above national administrative absorptive capacity (see Segura, 2006). For Chad, applying a standard PIH framework based on keeping the oil wealth constant in real terms for all future generations would lead to a very low sustainable non-oil primary deficit path and, given Chad's low tax ratio, to a very low level of primary expenditure, which would be difficult to justify on political and social grounds. In addition, the PIH could also need to be adjusted to take into account countries' initial fiscal position, in order to avoid a sharp adjustment to the sustainable non-oil primary balance. For example Leigh and Olters (2006) proposed a smoothing mechanism rule for consolidating the non-oil primary deficit to the sustainable PIH level, which as Gabon has already a relative high tax ratio, focuses on gradually reducing expenditure. In the case of Chad, the application of the PIH would require a very sharp adjustment in the non-oil primary deficit, starting in 2007, by reducing primary expenditure from the 26 percent of non-oil GDP registered in 2006 to the sustainable level of 11 percent (see Table 4 and Annex II).

Table 4. Chad: Long-Term Fiscal Policy under a Permanent Income Hypothesis 2006-2030

\begin{tabular}{lrrrrrr}
\hline & 2006 & 2007 & 2010 & 2020 & 2030 & $2007-2030^{2 /}$ \\
\hline & & & & & & \\
+ Non-oil revenue & 8.5 & 8.7 & 8.9 & 8.9 & 8.9 & 8.9 \\
+ Sustainable Income & 6.4 & 5.2 & 4.6 & 2.2 & 1.0 & 2.7 \\
- Debt service & 2.2 & 2.1 & 1.2 & 0.8 & 0.8 & 1.0 \\
- Other financing items & 1.5 & 0.9 & 0.4 & 0.0 & 0.0 & 0.2 \\
= Domestically Financed Primary Expenditure & 25.9 & 10.8 & 11.9 & 10.3 & 9.1 & 10.4 \\
Sustainable Non-oil primary balance & $\mathbf{- 1 6 . 6}$ & $\mathbf{- 2 . 1}$ & $\mathbf{- 3 . 0}$ & $\mathbf{- 1 . 4}$ & $\mathbf{- 0 . 1}$ & $\mathbf{- 1 . 6}$ \\
Oil revenue account balance & 3.2 & 28.7 & 34.5 & 52.4 & 33.8 & 43.2 \\
\hline
\end{tabular}

Sources: Fund staff estimates.

1/ Percentage of non-oil GDP.

2/ Average.

\footnotetext{
${ }^{53}$ Timor-Leste and Saõ Tomé and Príncipe have adopted legislation that implements a PIH (see Segura, 2006, and Kim, 2005), and the rule has been proposed for Gabon (Leigh and Olters, 2006), and Trinidad and Tobago (Velculescu and Rizavi, 2005).
} 
34. A long-term fiscal plan for the gradual and judicious transformation of the oil wealth into other forms of capital could be a better option for Chad, as outlined in Table 5. This paper proposes a modified PIH criterion based on smoothing the consumption of oil wealth during the period of production and reducing the exposure of the budget to oil revenue. For this option to succeed in leaving Chad in a sound fiscal and financial position when oil revenue is completed exhausted, the country must adopt expenditure and non-oil revenue policies conducive to ensuring the government has sound solvency and liquidity positions by the end of the period of oil production. To that end, fiscal policy should aim at ensuring that by the end of the period the nonoil balance is sufficient to cover debt service and other financing items, the government's stock of debt is manageable, and there is a reasonable volume of oil saving in the oil account to be used in the post-oil era. Table 5 outlines a baseline fiscal strategy for Chad, by 2030, to (i) gradually transform its oil wealth into physical, human and financial capital; (ii) implement a credible strategy to raise non-oil tax revenue to the CEMAC country average (16 percent of non-oil GDP); (iii) hold expenditure increases somewhat below the nominal non-oil GDP rate of growth (on average); and (iv) uses accumulated oil savings as the main financing item in the budget. ${ }^{54}$

\section{Second Step: Medium-Term Fiscal Plans}

35. While allowing sufficient flexibility to counter the volatility of the non-oil economy and increasing capital expenditure, Chad's medium-term fiscal plans should be geared to build up oil deposits in good times. Table 5 presents a proposed medium-term baseline fiscal policy. Given Chad's narrow and volatile tax base and inadequate tax administration, non-oil revenue is assumed to increase gradually (about 1 percent) over the medium term. After the expected phasing out of the high level of subsidies to public entities currently needed, fiscal consolidation should start in 2008 and continue afterwards, with Chad's total primary expenditure growing slightly less than nominal non-oil GDP over the long run. This fiscal policy will allow for the building up of a fiscal buffer during good times that would be used only in bad times, especially, when oil revenue starts to decline, so that the government can sustain its expenditure without having to resort to procyclical cuts or unexpected and costly borrowing. With this fiscal policy, during the "good years" 2006-07 and 2012-17, and 2026-30, the government would deposit on average 3 percent of non-oil GDP into the oil accounts and draw down 1 percent during the "bad years" 2008-11 and 2018-25. At the end of the period, Chad's non-oil primary balance would be positive at 0.8 percent of non-oil GDP, covering debt service and other financing items; expenditure would have been financed mostly by oil savings; the stock of capital accumulated would reach about 90 percent of non-oil GDP; and Chad would have built a long-term saving of about 7 percent of non-oil GDP in the oil account. Figure 8 illustrates the medium-term dynamics of main fiscal indicators in the baseline fiscal policy.

\footnotetext{
${ }^{54}$ If government borrowing is cheaper than drawing on the accumulated oil deposits, it could make sense to take advantage of it; however, in the baseline scenario it will be assumed that the government does not contract new borrowing to finance the deficit, in order to compare with alternative scenarios under which the government will need to do so. Regarding foreign-financed investment, it is assumed to remain around the current 6 percent of non-oil GDP, in all of the scenarios considered, with about half projects financed by grants and half by concessional loans.
} 
Table 5. Chad: A Viable Long-Term Fiscal Strategy for 2007-2030 - Baseline scenario

\begin{tabular}{|c|c|c|c|c|c|c|c|}
\hline & 2006 & 2007 & 2010 & 2020 & 2030 & $\begin{array}{c}\text { Deposits } \\
2006-07 \\
2012-17 \\
2026-2030\end{array}$ & $\begin{array}{c}\text { Withdrawals } \\
2008-2011 \\
2018-25^{1}\end{array}$ \\
\hline Nominal long-term interest rate (percent) & 2.9 & 2.9 & 2.9 & 2.9 & 2.9 & 2.9 & 2.9 \\
\hline \multicolumn{8}{|l|}{ Government Finance $^{2}$} \\
\hline Non-oil revenue ${ }^{7}$ & 8.5 & 8.7 & 9.5 & 12.9 & 16.4 & 12.5 & 12.1 \\
\hline Primary expenditure & 33.4 & 27.1 & 23.0 & 22.2 & 21.6 & 23.4 & 22.5 \\
\hline Current & 18.8 & 14.3 & 12.8 & 12.4 & 12.1 & 13.0 & 12.5 \\
\hline Of which: exceptional defense spending & 4.3 & 1.1 & 0.5 & 0.0 & 0.0 & 0.4 & 0.1 \\
\hline Capital & 14.6 & 12.8 & 10.2 & 9.8 & 9.4 & 10.4 & 10.0 \\
\hline Domestically financed & 6.3 & 5.4 & 4.3 & 3.9 & 3.5 & 4.2 & 4.0 \\
\hline Externally financed & 8.3 & 7.3 & 5.9 & 5.9 & 5.9 & 6.2 & 6.0 \\
\hline Of which: by loans & 4.1 & 3.6 & 2.6 & 2.6 & 2.7 & 2.8 & 2.7 \\
\hline Non-oil primary balance & -16.6 & -11.1 & -7.5 & -3.3 & 0.8 & -4.7 & -4.4 \\
\hline Financing & 4.6 & 4.3 & 4.3 & 5.1 & 5.1 & 4.8 & 4.8 \\
\hline External borrowing for capital projects & 8.3 & 7.3 & 5.9 & 5.9 & 5.9 & 6.2 & 6.0 \\
\hline Debt service due & -2.2 & -2.1 & -1.2 & -0.8 & -0.8 & -1.1 & -1.0 \\
\hline Other financing & -1.5 & -0.9 & -0.4 & 0.0 & 0.0 & -0.3 & -0.2 \\
\hline Deposit $(+) /$ Withdrawal (-) from oil account ${ }^{3}$ & 1.7 & 16.7 & -0.6 & -0.7 & 1.1 & 2.9 & -1.2 \\
\hline Gap financing borrowing & 0.0 & 0.0 & 0.0 & 0.0 & 0.0 & 0.0 & 0.0 \\
\hline \multicolumn{8}{|l|}{ Government's Balance Sheet } \\
\hline Oil revenue account balance (in percent of non-oil GDP) & 1.7 & 18.3 & 9.2 & 9.8 & 6.6 & 9.4 & 8.7 \\
\hline Oil wealth (in percent of non-oil GDP) ${ }^{4}$ & 226.5 & 197.1 & 141.6 & 38.0 & 6.6 & 75.4 & 71.0 \\
\hline Stock of public capital (percent of non-oil GDP) ${ }^{5}$ & 68.0 & 72.6 & 81.6 & 93.4 & 87.6 & 86.3 & 88.5 \\
\hline NPV-of-external debt-to-non-oil GDP & 21.9 & 21.4 & 21.3 & 21.8 & 19.0 & 20.8 & 21.4 \\
\hline Government's Net Financial Wealth (percent of non-oil GDP)6 & 204.6 & 175.7 & 120.3 & 16.2 & -12.4 & 54.6 & 49.6 \\
\hline $\begin{array}{l}\text { Sources: Fund staff estimates. } \\
\text { 1/ Average. } \\
\text { 2/ Percentage of non-oil GDP. } \\
\text { 3/ Yearly flow from the oil saving accounts. }\end{array}$ & & & & & & & \\
\hline \multicolumn{8}{|c|}{ 4/ The oil wealth $\mathrm{OW}_{\mathrm{t}}$ is defined as the stock of oil saving in t plus the NPV of future projected oil revenues. } \\
\hline \multicolumn{8}{|c|}{5 / The stock of capital $\mathrm{K}_{\mathrm{t}}$ is defined as $\mathrm{K}_{\mathrm{t}}=\mathrm{K}_{\mathrm{t}-1} \cdot(1-\partial)+\mathrm{I}_{\mathrm{t}}$, where $\partial=0.3$ is the depreciation rate, and $\mathrm{I}_{\mathrm{t}}$ the government's gross capital formation. } \\
\hline $\begin{array}{l}\text { 6/ The net financial wealth is defined as the oil wealth minus the NPV } \\
\text { 7/ The exploration permits and share premiums are included in oil rev }\end{array}$ & he exter & & & & & & \\
\hline
\end{tabular}

36. In principle it would be possible to define different combinations of expenditure and non-oil revenue from the one proposed in Table 5 that would comply with the proposed government's long-term fiscal goals. Overtime several allocations between spending and taxes are compatible with the targeted long-term non-oil primary deficit, for instance when the marginal benefit of spending equals the marginal cost of taxation. Arguments in favor of a front-loaded spending approach might be (1) the need for a critical mass of human and physical capital before economic takeoff can occur (Azariadis and Drazen, 1990); (2) political factors, such as unmet social needs; and (3) the positive impact of public spending on current and future economic growth (Takizawa, Gardner, and Ueda, 2004). In addition, if government spending has a high import content, such as infrastructure investment, public spending would yield a better supply response and will offset some of the adverse macroeconomic consequences of front-loading spending. ${ }^{55}$

\footnotetext{
${ }^{55}$ In line with Bevan (2005) and Adam (2005)'s conclusions in the context of scaling up aid, if oil revenue is assimilated to external aid flows.
} 
Figure 8. Chad: Long-Term Outlook 2007-30 Baseline scenario

Net Financial Wealth (Percent of non-oil GDP)

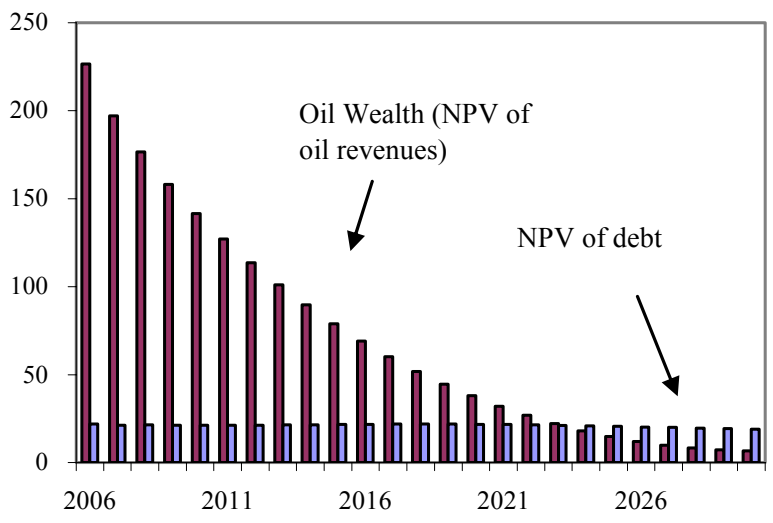

Long-Term Government Finances

(Percent of non-oil GDP)

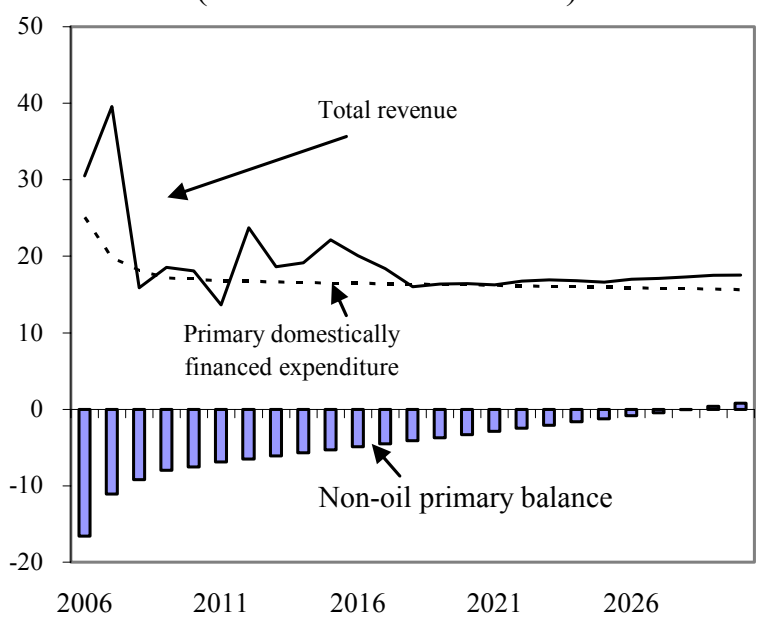

Government Primary Current Spending and Domestically Financed Investment (Percent of non-oil GDP)

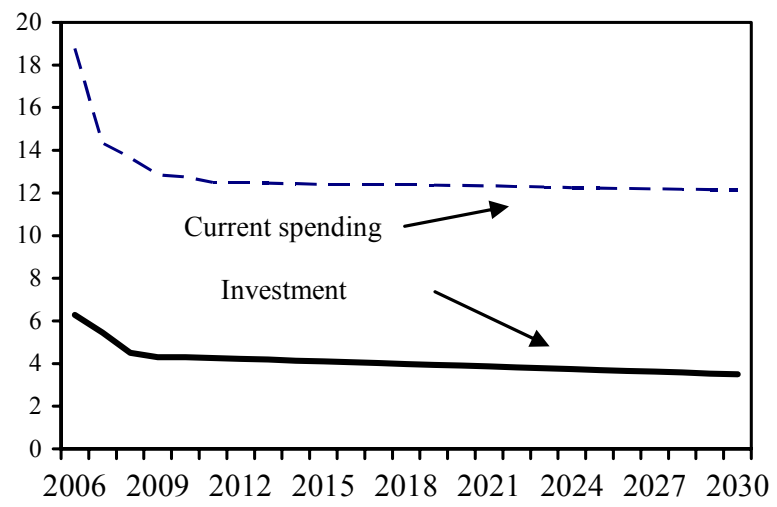

Tax Ratio and Stock of Oil Savings (Percent of non-oil GDP)

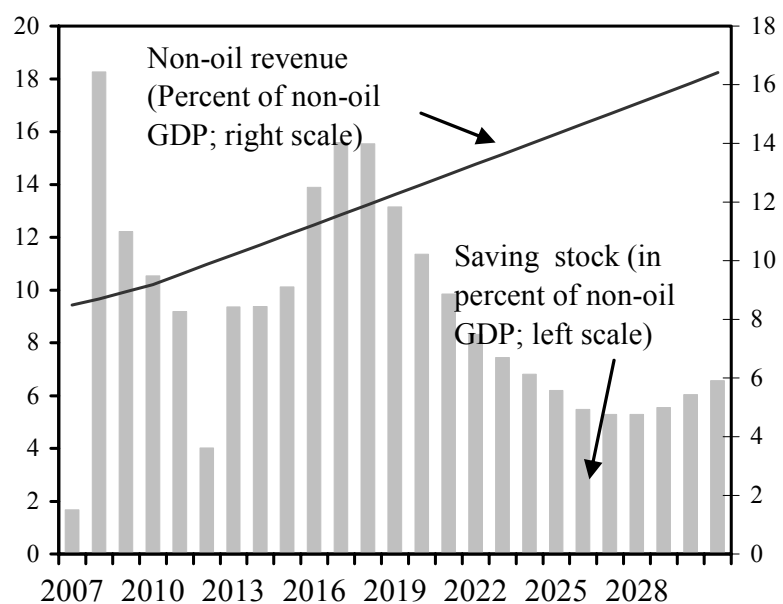

Source: Chadian authorities; and IMF staff estimates and projections.

37. The government's current medium-term expenditure framework (MTEF) for 2007-09 calls for a more pronounced frontloaded expenditure profile than in the medium-term fiscal plan proposed in Table 5. As presented in Table 6, the government current MTEF calls for a declining non-oil primary deficit that on average is $3 \frac{1}{2}$ percent of non-oil GDP larger than in the baseline scenario proposed in Table 5. The authorities argued that the country's immense development needs, and the population's expectations of immediate benefits from oil revenue, called for a frontloaded use of resources, especially in building the country's infrastructure, which would promote higher growth in the future. The authorities' approach would not necessarily jeopardize fiscal sustainability, although it may require implementing sharper fiscal adjustments after 2009. Such a frontloading entails some serious risks and vigilance will be required to monitor the implementation of the government's strategy. First, a frontloaded expenditure profile can exert upward pressure on inflation and real exchange rate, with all its negative consequences for the nonoil sector and poverty reduction. Second, it can strain the government's institutional capacity for planning, executing, and monitoring expenditure, creating substantial waste. Third, political and social constraints may make it difficult to reduce spending programs once they are in place. 
Moreover, large swings reduce the quality and efficiency of expenditure; they could be particularly costly for Chad's ill-diversified non-oil economy.

Table 6. Chad: MTEF paths for long term fiscal sustainability

(In percent of non-oil GDP)

\begin{tabular}{|c|c|c|c|}
\hline & $\begin{array}{l}2007 \\
\text { Proj. }\end{array}$ & $\begin{array}{l}2008 \\
\text { Proj. }\end{array}$ & $\begin{array}{l}2009 \\
\text { Proj. }\end{array}$ \\
\hline \multicolumn{4}{|l|}{ Staff proposal } \\
\hline Revenue & 39.6 & 15.9 & 18.5 \\
\hline Oil & 30.9 & 6.9 & 9.4 \\
\hline Non-oil 3/ & 8.7 & 8.9 & 9.2 \\
\hline Primary expenditure ${ }^{1 /}$ & 19.8 & 18.1 & 17.1 \\
\hline Of which: investment & 5.4 & 4.5 & 4.3 \\
\hline Non-oil primary balance & -11.1 & -9.2 & -8.0 \\
\hline Balance in oil revenue account & 18.3 & 12.2 & 10.5 \\
\hline \multicolumn{4}{|l|}{ Authorities proposal } \\
\hline Revenue & 39.6 & 15.8 & 18.6 \\
\hline Oil 2' & 30.9 & 6.9 & 9.4 \\
\hline Non-oil 3/ & 8.7 & 8.9 & 9.2 \\
\hline Primary expenditure ${ }^{1 /}$ & 23.2 & 21.45 & 20.5 \\
\hline Of which: investment & 6.6 & 6.9 & 6.6 \\
\hline Non-oil primary balance & -14.5 & -12.6 & -11.3 \\
\hline Balance in oil revenue account & 15.0 & 5.8 & 1.2 \\
\hline
\end{tabular}

Sources: Chadian authorities; and IMF staff projections.

1/ Domestically financed.

2/ After debt service.

3/ Exploration permits and share premiums are included in oil revenue.

\section{Sensitivity analysis}

38. Simple sensitivity analyses show how lower oil prices and alternative fiscal policy strategies impact the baseline fiscal path over the lung-run. Using the macroeconomic assumptions in Table 5, the following alternative scenarios were run (see Figure 9 and Table 7):

- Low Non-Oil Tax Ratio. If Chad fails to increase the non-oil tax ratio and keep it at about the current 8-9 percent of non-oil GD and maintain the domestically financed expenditure level of the baseline scenario, the non-oil primary deficit will increase by 5 percent of non-oil GDP above the baseline scenario. This would imply lower accumulation of oil deposits in "good years" and larger oil withdrawals in "bad years"; oil deposits would be completely depleted by 2019 after some consecutive savings/withdrawal periods; as oil revenue will not be sufficient to finance the expenditure plans, the NPV of the stock of debt would increase, ${ }^{56}$ and the government's net wealth $(\mathrm{NW})^{57}$ would deteriorate with respect to the baseline scenario.

\footnotetext{
${ }^{56}$ Assumptions for new disbursements are as follow: a 10 year period of grace, a 30 year period for repayment, interest of 1 percent, resulting in about 50 percent of concesionality.

${ }^{57}$ Defined as the oil wealth minus the NPV of the external debt.
} 
Table 7. Chad: Sensitivity Analysis of the Long-Term Fiscal Policy for 2006-2030 1/

\begin{tabular}{|c|c|c|c|c|c|c|c|c|c|}
\hline \multicolumn{10}{|c|}{ Low Non-oil Revenue Ratio } \\
\hline & $\begin{array}{l}\text { Deposits } \\
2006-7^{2 /} \\
\end{array}$ & $\begin{array}{c}\text { Withdrawals } \\
2008-11^{2 /} \\
\end{array}$ & $\begin{array}{c}\text { Deposit } \\
2012 \\
\end{array}$ & $\begin{array}{c}\text { Withdrawals } \\
2013-14^{2 /} \\
\end{array}$ & $\begin{array}{l}\text { Deposit } \\
\text { 2015-16 } \\
\end{array}$ & $\begin{array}{c}\text { Withdrawals } \\
2017-30^{2 /} \\
\end{array}$ & \begin{tabular}{|c|} 
Depletion \\
Point \\
2019 \\
\end{tabular} & 2030 & $2006-2030^{2 /}$ \\
\hline Non-oil revenue & 8.6 & 8.9 & 9.2 & 9.3 & 9.5 & 10.3 & 9.9 & 11.0 & 9.8 \\
\hline Primary Expenditure (domestically financed) & 22.4 & 17.3 & 17.2 & 16.6 & 16.5 & 16.0 & 16.3 & 15.6 & 16.8 \\
\hline Current & 16.6 & 12.9 & 13.0 & 12.5 & 12.4 & 12.3 & 12.4 & 12.1 & 12.8 \\
\hline Capital (domestically financed) & 5.9 & 4.3 & 4.2 & 4.2 & 4.1 & 3.8 & 3.9 & 3.5 & 4.1 \\
\hline Oil revenue account balance & 10.0 & 8.2 & 6.8 & 5.5 & 7.7 & 0.6 & 0.0 & 0.0 & 3.8 \\
\hline Financing gap borrowing & 0.0 & 0.0 & 0.0 & 0.0 & 0.0 & 3.8 & 1.7 & 4.6 & 3.0 \\
\hline Stock of public capital & 70.3 & 80.3 & 85.8 & 88.3 & 90.6 & 91.3 & 93.1 & 87.6 & 87.4 \\
\hline Oil wealth (percent of non-oil GDP) ${ }^{3}$ & 202.6 & 153.2 & 106.5 & 91.5 & 65.2 & 18.2 & 35.0 & 0.0 & 67.7 \\
\hline NPV-of-external debt-to-non-oil GDP & 21.6 & 21.4 & 21.4 & 21.5 & 21.7 & 27.5 & 21.9 & 34.5 & 24.9 \\
\hline Net financial wealth (percent of non-oil GDP) ${ }^{4}$ & 181.0 & 131.9 & 85.1 & $\mathbf{7 0 . 0}$ & 43.6 & -9.3 & 13.1 & -34.5 & 42.9 \\
\hline \multicolumn{10}{|c|}{ High Expenditure Level } \\
\hline Non-oil revenue & 8.6 & 9.1 & 9.2 & 9.5 & 11.2 & 12.9 & 14.7 & 16.4 & 12.3 \\
\hline Primary Expenditure (domestically financed) & 24.9 & 24.8 & 24.9 & 24.7 & 24.9 & 24.9 & 24.6 & 24.2 & 24.7 \\
\hline Current & 18.7 & 18.8 & 18.9 & 18.7 & 18.9 & 18.9 & 18.6 & 18.2 & 18.7 \\
\hline Capital (domestically financed) & 6.1 & 6.0 & 6.0 & 6.0 & 6.0 & 6.0 & 6.0 & 6.0 & 6.0 \\
\hline Non-oil primary balance & -16.3 & -15.8 & -15.7 & -15.1 & -13.6 & -11.9 & -10.0 & -7.8 & -12.4 \\
\hline Oil revenue account balance & 7.5 & 0.5 & 0.0 & 0.0 & 0.0 & 0.0 & 0.0 & 0.0 & 0.6 \\
\hline Financing gap borrowing & 0.0 & 3.8 & 7.7 & 8.3 & 4.3 & 10.1 & 10.5 & 9.6 & 7.8 \\
\hline Stock of public capital & 70.6 & 80.7 & 82.7 & 86.4 & 100.6 & 107.8 & 108.3 & 106.5 & 98.9 \\
\hline Oil wealth (percent of non-oil GDP)3 & 202.6 & 162.8 & 148.6 & 132.5 & 65.0 & 28.2 & 9.4 & 0.0 & 64.8 \\
\hline NPV-of-external debt-to-non-oil GDP & 21.6 & 27.8 & 29.9 & 36.4 & 48.1 & 67.1 & 77.3 & 74.7 & 56.4 \\
\hline Net financial wealth (percent of non-oil GDP)4 & 181.0 & 135.0 & 118.7 & 96.0 & 16.9 & -38.9 & -67.9 & -74.7 & 8.4 \\
\hline \multicolumn{10}{|c|}{ Low Oil Revenue } \\
\hline & $\begin{array}{l}\text { Deposit } \\
\text { 2006-07 } \\
\end{array}$ & $\begin{array}{c}\text { Withdrawals } \\
2008-09^{2 /}\end{array}$ & \begin{tabular}{c|} 
Depletion \\
Point \\
2009 \\
\end{tabular} & 2010 & 2015 & 2020 & 2025 & 2030 & $2006-2030^{2 /}$ \\
\hline Non-oil revenue & 8.6 & 9.1 & 9.2 & 9.5 & 11.2 & 12.9 & 14.7 & 16.4 & 12.3 \\
\hline Primary Expenditure (domestically financed) & 22.4 & 17.6 & 17.1 & 17.1 & 16.5 & 16.3 & 15.9 & 15.6 & 16.8 \\
\hline Current & 16.6 & 13.2 & 12.8 & 12.8 & 12.4 & 12.4 & 12.2 & 12.1 & 12.8 \\
\hline Capital (domestically financed) & 5.9 & 4.4 & 4.3 & 4.3 & 4.1 & 3.9 & 3.7 & 3.5 & 4.1 \\
\hline Non-oil primary balance & -13.8 & -8.6 & -8.0 & -7.5 & -5.3 & -3.3 & -1.3 & 0.8 & -4.6 \\
\hline Oil revenue account balance & 7.3 & 3.1 & 0.0 & 0.0 & 0.2 & 0.0 & 0.0 & 0.0 & 0.8 \\
\hline Financing gap borrowing & 0.0 & 11.4 & 1.6 & 6.4 & 0.0 & 2.0 & 1.4 & 0.0 & 1.4 \\
\hline Stock of public capital & 70.3 & 78.0 & 79.2 & 81.6 & 90.2 & 93.4 & 91.3 & 87.6 & 87.4 \\
\hline Oil wealth (percent of non-oil GDP)3 & 119.8 & 97.0 & 90.2 & 78.0 & 43.8 & 19.0 & 6.2 & 0.0 & 40.3 \\
\hline NPV-of-external debt-to-non-oil GDP & 21.6 & 21.8 & 22.2 & 25.3 & 33.0 & 34.9 & 32.8 & 27.2 & 30.3 \\
\hline Net financial wealth (percent of non-oil GDP)4 & 98.1 & 75.1 & 68.0 & 52.6 & 10.8 & -15.9 & -26.6 & -27.2 & 9.9 \\
\hline \multicolumn{10}{|c|}{ Combined Scenarios } \\
\hline & $\begin{array}{l}\text { Deposit } \\
\text { 2006-07 } \\
\end{array}$ & $\begin{array}{c}\text { Withdrawals } \\
20082 / \\
\end{array}$ & \begin{tabular}{c|} 
Depletion \\
Point 2008 \\
\end{tabular} & 2010 & 2015 & 2020 & 2025 & 2030 & $2006-2030^{2 /}$ \\
\hline Non-oil revenue & 8.6 & 8.8 & 8.8 & 9.0 & 9.5 & 10.0 & 10.5 & 11.0 & 9.8 \\
\hline Primary Expenditure (domestically financed) & 24.9 & 24.8 & 24.8 & 24.7 & 24.9 & 24.9 & 24.6 & 24.2 & 24.7 \\
\hline Current & 18.7 & 18.8 & 18.8 & 18.7 & 18.9 & 18.9 & 18.6 & 18.2 & 18.7 \\
\hline Capital (domestically financed) & 6.1 & 6.0 & 6.0 & 6.0 & 6.0 & 6.0 & 6.0 & 6.0 & 6.0 \\
\hline Non-oil primary balance & -16.3 & -16.0 & -16.0 & -15.7 & -15.4 & -14.9 & -14.1 & -13.2 & -14.9 \\
\hline Oil revenue account balance & 4.9 & 0.0 & 0.0 & 0.0 & 0.0 & 0.0 & 0.0 & 0.0 & 0.4 \\
\hline Financing gap borrowing & 0.0 & 5.2 & 5.2 & 14.5 & 9.7 & 13.3 & 13.7 & 13.4 & 13.3 \\
\hline Stock of public capital & 70.6 & 78.7 & 78.7 & 86.4 & 100.6 & 107.8 & 108.3 & 106.5 & 98.9 \\
\hline Oil wealth (percent of non-oil GDP)3 & 119.8 & 99.2 & 99.2 & 78.0 & 43.8 & 19.0 & 6.2 & 0.0 & 39.8 \\
\hline NPV-of-external debt-to-non-oil GDP & 21.6 & 24.1 & 24.1 & 38.4 & 65.0 & 85.2 & 94.5 & 96.6 & 69.7 \\
\hline Net financial wealth (percent of non-oil GDP) 4 & 98.1 & 75.1 & 75.1 & 39.6 & -21.3 & -66.1 & -88.3 & -96.6 & -29.9 \\
\hline
\end{tabular}

Sources: Fund staff estimates.

1/ Percent of non-oil GDP, unless otherwise indicated.

2/ Average

3/ The oil wealth OWt is defined as the stock of oil saving in t plus the NPV of future projected oil revenues.

4 / The net financial wealth is defined as the oil wealth minus the NPV of the external debt. 
Figure 9. Chad: Sensitivity Analysis of the Long-Term Fiscal Outlook 2006-30

Chad: Stock of savings under alternative fiscal frameworks (In percent of non-oil GDP)

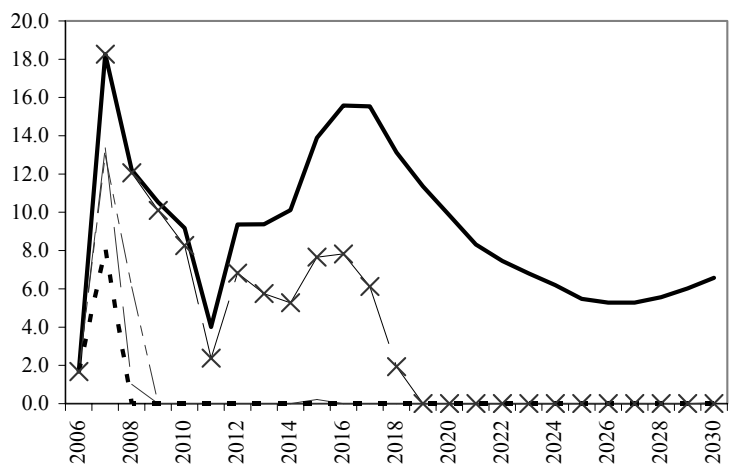

B Baseline
_ _ - High Expenditure

Chad: Net wealth under alternative fiscal frameworks (In percent of non-oil GDP)

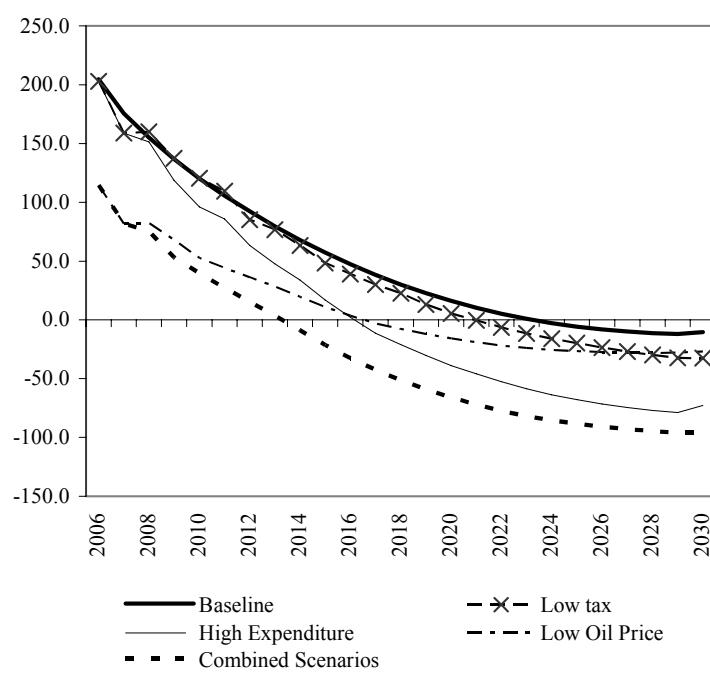

Chad: NPV of debt under alternative fiscal frameworks (In percent of non-oil GDP)

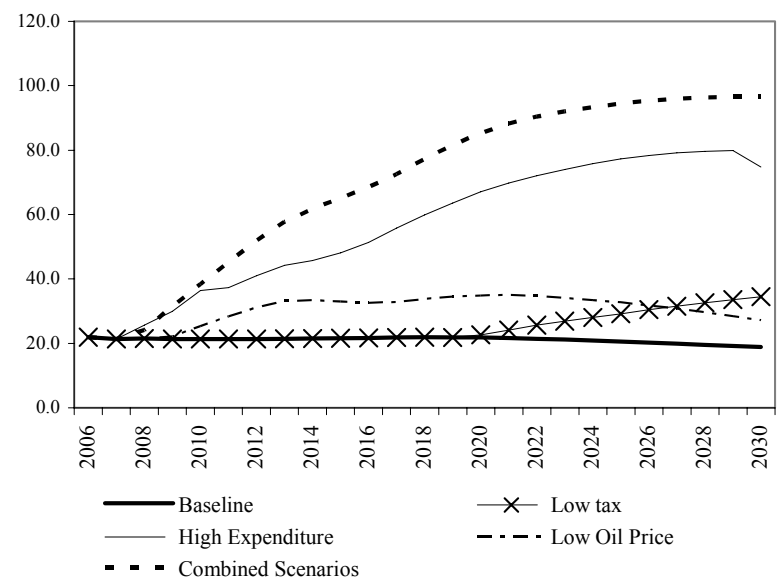

Chad: Non-oil primary deficit under alternative fiscal frameworks (In percent of non-oil GDP)

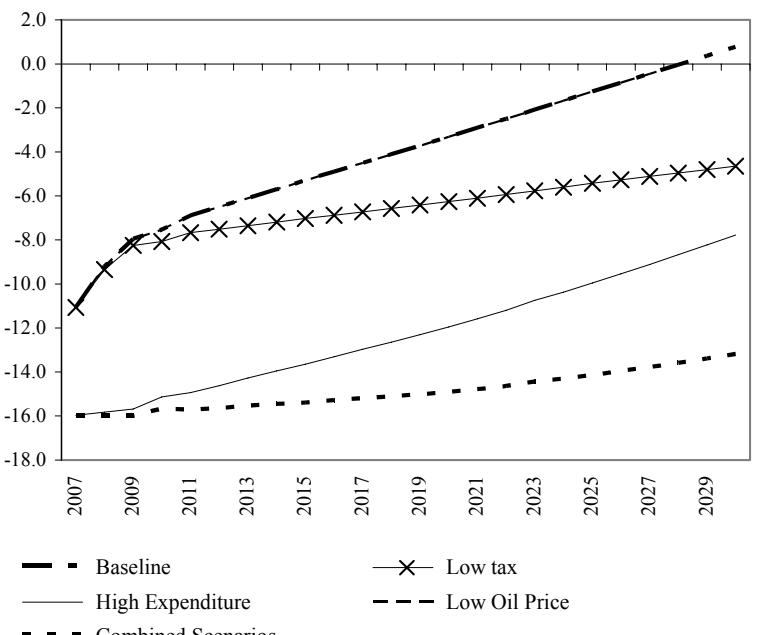

Source: Chadian authorities; and IMF staff estimates and projections.

- High Spending. A policy in which the domestically financed expenditure began to rise more quickly than non-oil revenue will increase non-oil primary deficits, which will require large withdrawals from the oil accounts. In this scenario the stock of accumulated oil deposits will be depleted by 2009. If at that point expenditure is difficult to adjust, the government would have to find financing of about 10 percent of non-oil GDP on average over the long term, which will explode debt NPV and significantly undermine the government's NW.

- Low Oil Price. In this scenario oil prices are assumed to be 10 percent below baseline and nonoil revenue and expenditure hold at baseline levels. Here the dynamics of the non-oil primary deficit is the same as in the baseline scenario, but with lower oil revenue, the deficit will need to be financed with larger and earlier withdrawals from the oil account. Though NPV of the debt 
would not explode, it would increase substantially after oil deposits are depleted in 2009, which would deteriorate the government NW path compared to the baseline scenario.

- Combined scenarios. This scenario assumed not only lower oil prices but also government failure to increase non-oil tax revenue and control expenditure growth. The oil deposits accumulated during 2006-07 would then be used to finance the non-oil primary deficit of 16 percent of non-oil GDP, therefore be fully depleted, in 2008. Afterwards, the government would be forced to look for new loans, which would lead to an explosive path for the debt NPV and a highly negative value of the government's NW.

\section{F. A Sound Institutional Framework for Chad Long-Term Fiscal Policy}

\section{Rationale and General Principles}

39. The establishment of a well-conceived framework for fiscal policy formulation and implementation can help governments achieve their fiscal targets over both the medium and the long term. Most countries find it difficult to build up public savings when they have a large oil windfall, especially nonindustrialized and natural resource-rich economies where traditional budgetary resources are highly volatile — exacerbated by volatile commodity prices — and shaky political institutions foster shortsighted policies by giving policymakers unchecked discretion (Talvi and Végh, 2000).

40. However, cross-country experiences with such frameworks have been mixed, particularly in resources-rich economies. Several countries have implemented frameworks to help fiscal management including fiscal rules, fiscal responsibilities laws, and in the specific case of oil producing countries, oil funds and budgetary oil prices rules. Lessons from country experience highlight that for these special frameworks to improve fiscal management they should cover all relevant fiscal (and quasi-fiscal) operations of the public sector, be based on well-defined procedural and transparency rules, and promote the strengthening of public expenditure management systems, which ultimately need to be sufficiently developed to monitor and enforce the requirements and sanctions of the fiscal framework ${ }^{58}$

41. Chad could benefit from the introduction of well-defined and tailored fiscal framework to support its long-term fiscal strategy, so that budgeting can be oriented away from annual targets and toward attainment of long-term fiscal goals. The main guiding principles of a fiscal framework for Chad should be (Table 8) long-term fiscal sustainability and macroeconomic stability, keeping public expenditure in line with Chad's absorptive capacity and saving some oil revenue to finance public spending after the oil is exhausted; poverty reduction and promotion of non-oil sector growth, responding to the government's PRSP; best public finance management practices, such as a unified and sound budgeting and assets management system; transparency, with regular explanations to the public of governments fiscal policy and outcomes, and strategy changes, especially as they relate to the use of oil revenue; and credibility, building enforcement mechanisms and contingency clauses that reduce discretion to circumvent the objectives stated in the mediumand long-term fiscal strategy.

\footnotetext{
${ }^{58}$ See Davis, Ossowski and Fedelino (2003) and International Monetary Fund (2005).
} 


\section{Main features of a reformed fiscal framework for Chad}

\section{Fiscal policy should be grounded in routine assessment of long-term fiscal}

sustainability. The government should base its fiscal policy strategy on long-term projections, under baseline and alternative scenarios, of revenue and expenditure, including estimates of how present policy decisions will affect future spending. The budget should incorporate all gross oil revenue the government receives directly or indirectly from any petroleum operations; they would be projected using realistic assumptions for oil prices and production. Because oil prices are so volatile and oil production will eventually be exhausted, a transparent "prudence" factor should then be applied and due considerations should also be given to ensuring some long-term savings. Loans should be sought only in amounts and on terms that future debt service does not jeopardize the accumulation of oil deposits. Whenever there is new information, the long-term fiscal sustainability assessment should be revised.

\section{The annual budget law should be formulated in a medium-term fiscal framework (MTFF) with a three-year rolling spending ceiling (in CFA francs) that recognizes Chad's} absorptive capacity and more pressing social needs; the ceiling would be consistent with the PRSP and the non-oil primary deficit defined by the sustainability assessment. The MTEF should be drafted using a top-down approach in which the central government sets spending ceilings for line ministries and guides them on how to prioritize their requests. The central MTFF and those for line ministries should be updated each year just before the budget for the following year is drafted so that its allocations correspond to the first year of the rolling three-year spending ceiling. Because oil revenue is highly uncertain, they might be used only to finance the part of the non-oil primary deficit not covered by budget support and other sources of financing.

44. The annual budget and the MTEFs should be pro-poor. An important share of spending would be allocated to priority sectors, as defined in the PRSP, such as spending on health and education, infrastructure, rural and agricultural development, energy, security (police), justice, and specific programs for producing regions. Any revision of the priorities should be based on a predictable, structured, PRSP-based review. The annual budget and the MTEFs might include numerical targets such as floors (in CFA francs) or percentages of total expenditure for selected priority programs, but only to serve as indicative targets. Each priority sector ministry should draft a medium-term budget that sets priorities for public investment in terms of the spending ceiling established for each ministry in the three-year MTFF, and draw up a list of eligible projects that gives the highest-yielding ones the highest priority. 


\begin{tabular}{|c|c|c|c|c|c|c|c|c|}
\hline & 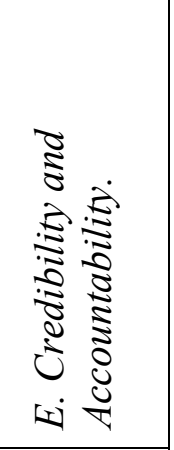 & & 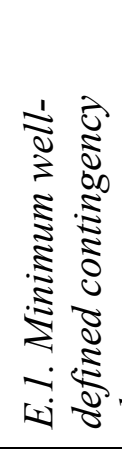 & 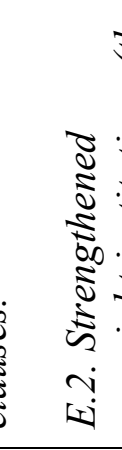 & 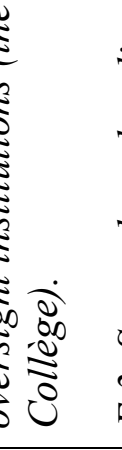 & 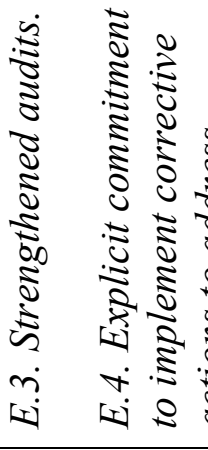 & & \\
\hline & 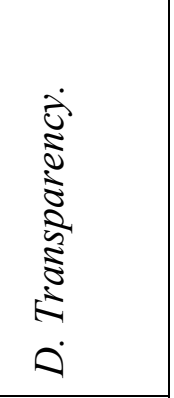 & & 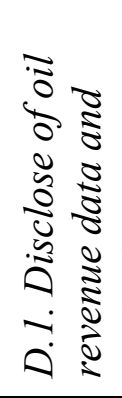 & 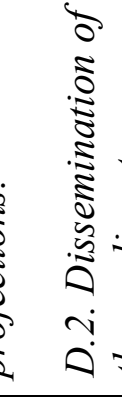 & 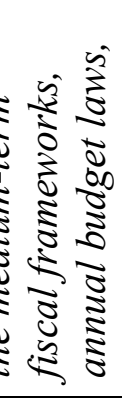 & 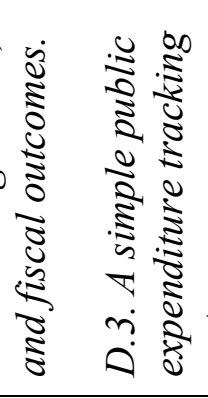 & 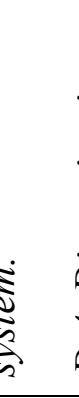 & 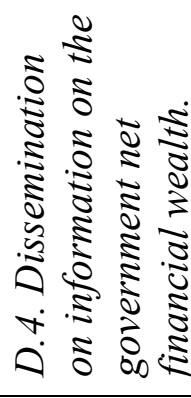 \\
\hline 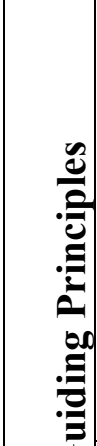 & 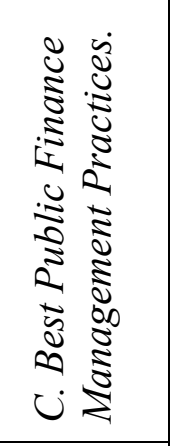 & 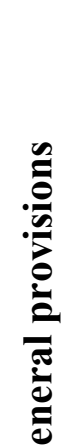 & 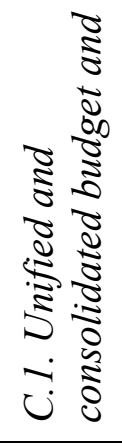 & 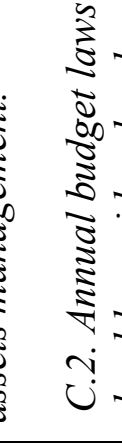 & 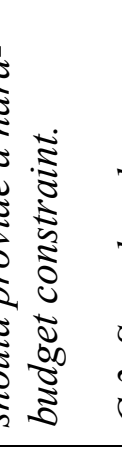 & 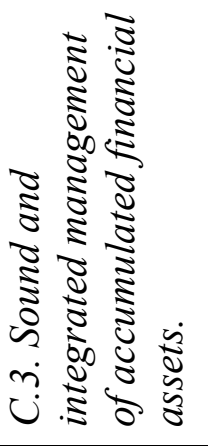 & & \\
\hline 0 & 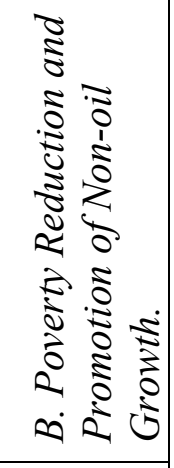 & U & 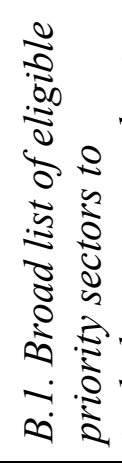 & 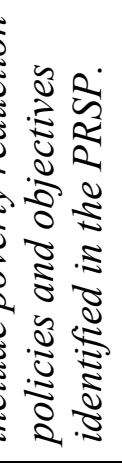 & 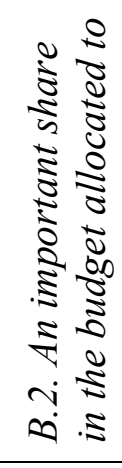 & 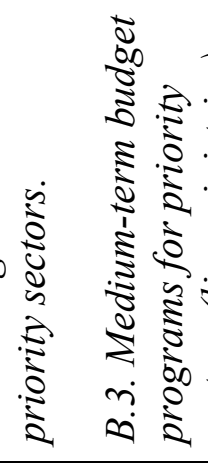 & & \\
\hline & 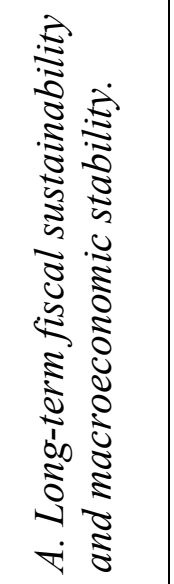 & & 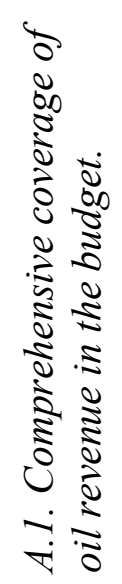 & 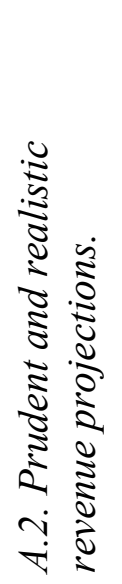 & 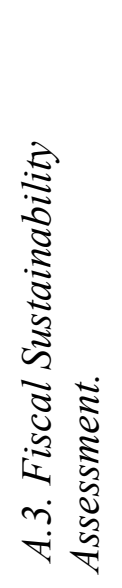 & 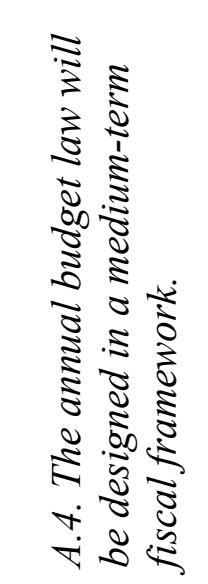 & 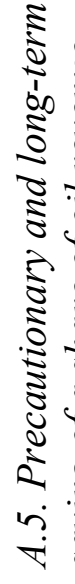 & 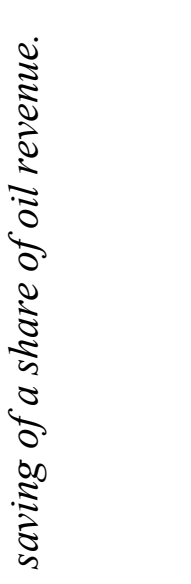 \\
\hline
\end{tabular}




\section{Chad's fiscal framework should reinforce transparency to create an} environment that binds both current and future governments to a sound and pro-poor use of oil revenue. It would call for comprehensive disclosure not just of oil revenue data and projections but also of other operations of the oil sector and the main characteristics of conventions and tax exceptions granted to oil companies. Oil companies should also be expected to comply with international accounting principles and transparency standards. The framework would also commit the government to adhere to best international practices on dissemination of information on oil revenue (e.g. EITI). It would also mandate the submission of the MTFFs to the National Assembly together with the budget; both documents will (i) detail information on how the non-oil primary deficit will be covered by the use of oil revenue; (ii) be explained in presentations to local leaders, trade unions, and other representatives of civil society and the public. In disseminating information on the execution of the annual budget, deviations from targets should be explained. To detect waste and leakage, a public expenditure tracking system for priority spending should be adopted. While effective government accounting, reporting and audit systems are being developed in Chad as part of the government's action plan to strengthen public financial management, ${ }^{59}$ budget programs in priority sectors could be assigned codes and monitored by the Collège, especially in the last stage of actual delivery. Moreover, the framework would stipulate that budget documents should include information on the government's consolidated net wealth. The Ministry of Finance would produce an annual report describing transactions in the oil saving accounts (deposits, withdrawals, balance, financial return on the oil investment account and financial instruments in which it is invested).

46. The fiscal framework could include carefully defined contingency clauses and provisions to strengthen oversight and accountability. Contingency clauses (e.g., defining the circumstances when transfers from the oil saving account to the Treasury Single Account (TSA) might be higher than budgeted, or elaborating a budget in which allocations to priority sectors may be smaller than usual) should be reduced to a minimum to ensure that the rulesbased fiscal framework and the annual budget stay credible. Contingency clauses should be only evoked in truly exceptional circumstances that are clearly defined (e.g., a fall in oil prices or production that is faster or larger than expected, natural disaster, severe recession, or armed conflict) and triggered only with the approval of the legislature. The framework would also extend the Collège's oversight role to all priority spending programs and shift from the current ex-ante control within the expenditure cycle to ex-post controls. The Collège would also publish an annual report reflecting its assessment to be presented and explained to the National Assembly, and the public, along with the draft annual budget law. Moreover, the oil saving and investment accounts will be audited annually by an independent auditor of international reputation; audits will include audited and reconciled data on oil production, sales, and prices and will be promptly posted on the government's web side and published in domestic and international newspapers.

\footnotetext{
${ }^{59}$ It refers to the Plan d'Action pour la Modernization des Finances Publiques, PAMFIP recently adopted by the government.
} 
47. The framework will make explicit commitments to correct detected

irregularities. It would stipulate that, in response to irregularities reported by the Collège or other oversight institutions, the Ministry of Finance would submit to the National Assembly along with the draft budget law a plan of corrective actions to be taken in the following fiscal year. The ministry would also report on progress made in addressing irregularities previously reported.

\section{G. Conclusions}

48. Chad's long-term fiscal sustainability could be assessed with a simple yet consistent accounting framework for projecting the government's non oil primary balance and net wealth. Given the limitations of Chad's statistical system and the technical difficulties of applying a full-fledged macroeconomic this paper proposed to assess long-term fiscal sustainability by using a consistent accounting framework within which projections of the balance sheet of the public sector can be made. Despite its obvious limitations, the framework does give useful insights about alternative long-term fiscal paths and the impact of external shocks that may have advantages for operational work.

49. A sound long-term fiscal strategy for Chad would aim to manage non-oil revenue and expenditure so as to compensate for depletion of oil revenue. The strategy implies the adoption of (i) a sustainable long-term fiscal strategy that, given Chad's relatively small and finite oil reserves, could entail the gradual yet full transformation of oil wealth into other forms of capital using responsible medium-term expenditure programs and measures to progressively increase non-oil revenue; (ii) a new institutional framework to reorient budgeting away from annual targets toward long-term fiscal goals, and guarantee efficient and transparent execution of oil revenue-financed spending. The new framework will include a unified budget and cash management system, under which all oil, and non-oil resources will be managed jointly, a simplified stabilization mechanism, according to which oil revenue would be allocated to finance the non-oil deficit, through transparent, but flexible management rules, and a simplified, yet fully transparent, banking circuit consistent with a TSA .

50. Successful implementation of a viable long-term fiscal strategy would require broad political consensus, significant capacity building, and better system for public financial management. It ultimately would depend on (i) government political commitment and society consensus and support for a measured approach to the use of oil revenue; (ii) government will to increase its ability in fiscal policy analysis and project appraisals; and (iii) progress on strengthening public financial management. 


\section{References}

Adam, C., 2005, "Exogenous Inflows and Real Exchange Rate: Theoretical Quirck or Empirical Reality?", paper presented at IMF Seminar on Foreign Aid and Macroeconomic Management, Maputo, Mozambique, March 14-15, available at: http://www.imf.org/external/np/seminars/eng/2005/famn/pdf/adam.pdf.

Azariadis, Costas, and Allan Drazen, 1990, "Threshold Externalities in Economic Development", Quarterly Journal of Economics, Vol. 105 (May).

Bevan, D. L. 2005, “ An Analytical Overview of Aid Absorption: Recognizing and Avoiding Macroeconomics Hazards", paper presented at IMF Seminar on Foreign Aid and Macroeconomic Management, Maputo, Mozambique, March 14-15, available at: http://www.imf.org/external/np/seminars/eng/2005/famn/pdf/bevan.pdf.

Davis, J.M., R. Ossowski, and A. Fedelino, 2003, Fiscal Policy Formulation and Implementation in Oil-Producing Countries (Washington: International Monetary Fund).

ExxonMobil, 2004a, "Chad/Cameroon Development Project, Report No 16, Third Quarter 2004," available at http://www.essochad.com/ChadEnglish/PA/Newsroom/TD ProgressReports.asp.

ExxonMobil, 2004b, "Communique Concerning the Government of Chad's Dispute with ExxonMobil," available at http://www.catholicrelief.org.

ExxonMobil, 2005, "Chad Export Project, Project Update No. 18, Mid-year 2005," available at http://www.essochad.com/Chad-English/PA/Newsroom/TD ProgressReports.asp.

ExxonMobil, 2006, “ Chad/Cameroon Development Project, Project Update No. 20”, available at http://www.essochad.com/ChadEnglish/PA/Newsroom/TD_ProgressReports.asp.

Gary, I., and N. Reisch, 2005, Chad's Oil: Miracle or Mirage? Following the Money in Africa's Newest Petro-State (Baltimore: Catholic Relief Services, and Washington: Bank Information Center).

International Monetary Fund, 2005, Fiscal responsibility Laws (forthcoming Occasional Paper on Promoting Fiscal Discipline, IMF 2007), (Washington DC).

Kim, Y. K., 2005, "Managing Oil/Gas Wealth in Timor-Leste", in Democratic Republic of Timor-Leste-Selected Issues and Statistical Appendix, IMF Country Report No 05/150, pp. 16-99 (Washington: International Monetary Fund).

Leigh, D., and J.P. Olter, 2006, "Natural Resource Endowments, Bad Habits, and Sustainable Fiscal Policies: Lessons from Gabon," memo (Washington: International Monetary Fund).

Segura, A., 2006, "Management of Oil Wealth under the Permanent Income Hypothesis: The Case of Saõ Tomé and Príncipe" (Washington: International Monetary Fund).

Takizawa, H., E. H. Gardner, and K. Ueda, 2004, “Are Developing Countries Better Off Spending Their Oil Wealth Upfront?” IMF Working Paper WP/04/141 (Washington D.C., International Monetary Fund).

Talvi, E. and Carlos, Vegh, 2000, “Tax Base Variability and Procyclical Fiscal Policy”, NBER Working Paper No. 7499 (Cambridge, Massachusetts: National Bureau of Economic Research).

Velculescu, D. and Rizavi, S. (2005), “Trinidad and Tobago: The Energy Boom and Proposals for a Sustainable Fiscal Policy”, WP/05/197, International Monetary Fund, Washington DC. 
Annex I. Legal Framework for Petroleum Revenue Management in Chad

\begin{tabular}{|c|c|c|c|}
\hline & Laws/Decrees & Year & Major provisions \\
\hline 1 & $\begin{array}{l}\text { Law on the management of oil revenue } \\
(002 / \mathrm{PR} / 06) \text { amending Law } 001 / \mathrm{PR} / 99\end{array}$ & & $\begin{array}{l}\text { Eliminates the Fund for Future } \\
\text { Generations, increases the share of } \\
\text { non-earmarked oil revenue form } 13 \frac{1}{2} 2 \\
\text { percent o } 30 \text { percent, extends the list } \\
\text { of eligible priority sectors to include } \\
\text { security, interterritorial administration } \\
\text { and justice, entrusts the Council of } \\
\text { Ministry with the authority to modify } \\
\text { the list of priority sectors, extends the } \\
\text { law to all oil fields to be develop in } \\
\text { Chad, and the tenure of the members } \\
\text { of the Collège. }\end{array}$ \\
\hline 2 & $\begin{array}{l}\text { Law on the management of oil revenue } \\
(001 / \mathrm{PR} / 99 \text { of } 01 / 11 / 1999)\end{array}$ & 1999 & $\begin{array}{l}\text { Defines direct and indirect oil } \\
\text { revenue } \\
\text { Defines the priority expenditure } \\
\text { sectors } \\
\text { Defines the amounts of revenue } \\
\text { earmarked for specific uses } \\
\text { Defines management procedures for } \\
\text { the special accounts } \\
\text { Creates oversight agencies }\end{array}$ \\
\hline 3 & Law 016/PR/2000 amending Law 001/PR/99 & & $\begin{array}{l}\text { Modifies the composition of the Oil } \\
\text { Revenue Control and Monitoring } \\
\text { Board (CCSRP) }\end{array}$ \\
\hline 4 & $\begin{array}{l}\text { Decree } 096 \text { of } 03 / 18 / 2004 \text { on the Future } \\
\text { Generations Fund (FGF) }\end{array}$ & 2004 & $\begin{array}{l}\text { Defines the conditions governing the } \\
\text { withdrawal of funds from the FGF } \\
\text { Creates the Investment Committee } \\
\text { Defines the procedures for financial } \\
\text { management of the FGF } \\
\text { Defines the audit procedures }\end{array}$ \\
\hline 5 & $\begin{array}{l}\text { Decree } 239 \text { of } 07 / 01 / 2003 \text { on expenditure } \\
\text { stabilization }\end{array}$ & 2003 & $\begin{array}{l}\text { Stipulates that earmarked oil revenue } \\
\text { must be deposited in a special account } \\
\text { The funds are used in accordance } \\
\text { with the budget } \\
\text { Priority sector expenditure cannot be } \\
\text { frozen or limited by a ceiling during } \\
\text { the fiscal year } \\
\text { Defines the basis ( } 42.6 \text { percent of the } \\
\text { budget) for financing the priority } \\
\text { sectors without special allocations } \\
\text { Automatic carryover of expenditure } \\
\text { without special allocation, financed } \\
\text { and not executed at the end of the } \\
\text { year }\end{array}$ \\
\hline
\end{tabular}




\begin{tabular}{|c|c|c|c|}
\hline 6 & $\begin{array}{l}\text { Decree } 238 \text { of } 07 / 01 / 2003 \text { establishing procedures } \\
\text { for the sterilization of oil revenue }\end{array}$ & 2003 & $\begin{array}{l}\text { Establishes mechanisms for the } \\
\text { automatic sterilization of oil revenue } \\
\text { Direct oil revenue is distributed as } \\
\text { follows: } 5 \text { percent to the producing } \\
\text { region account, } 15 \text { percent to the } \\
\text { Treasury current account at the } \\
\text { BEAC, and the balance to the } \\
\text { stabilization account used to pay } \\
\text { commercial banks the amounts } \\
\text { needed to carry out priority } \\
\text { operations. } \\
\text { Indirect oil revenue is deposited } \\
\text { directly in the Treasury current } \\
\text { account at the BEAC as unallocated } \\
\text { resources. }\end{array}$ \\
\hline 7 & Decree 240 of $07 / 01 / 03$ on the CCSRP & 2003 & $\begin{array}{l}\text { Determines the composition of the } \\
\text { CCSRP } \\
\text { Detailed provisions concerning } \\
\text { CCSRP meetings } \\
\text { Detailed operating provisions } \\
\text { The CCSRP authorizes all } \\
\text { expenditure financed with oil revenue } \\
\text { and approves all contracts from the } \\
\text { perspective of resource management }\end{array}$ \\
\hline 8 & $\begin{array}{l}\text { Decree } 095 \text { of } 03 / 18 / 04 \text { on the allocation of oil } \\
\text { revenue to the producing region }\end{array}$ & 2004 & $\begin{array}{l}\text { Temporary mechanisms pending the } \\
\text { establishment of decentralized local } \\
\text { structures } \\
\text { Provides for the opening of an } \\
\text { account at the BEAC for the } \\
\text { producing region }\end{array}$ \\
\hline 9 & $\begin{array}{l}\text { Decree } 457 \text { of } 09 / 29 / 04 \text { and Regulation } 1924 \text { for } \\
\text { the creation of the Provisional Committee for } \\
\text { managing oil revenue earmarked to the producing } \\
\text { region. }\end{array}$ & 2004 & $\begin{array}{l}\text { Outlines the organization and } \\
\text { responsibilities of the Committee and } \\
\text { appoints current members of the } \\
\text { committee. }\end{array}$ \\
\hline 10 & $\begin{array}{l}\text { Decree } 168 \text { of } 03 / 26 / 01 \text { on the organization, } \\
\text { operations, and conditions of the Oil Revenue } \\
\text { Oversight Body (the Collège) }\end{array}$ & 2001 & $\begin{array}{l}\text { Outlines the organization, operational } \\
\text { procedures, and control and oversight } \\
\text { mechanisms available to the Collège. }\end{array}$ \\
\hline \multirow[t]{2}{*}{11} & Decree 579 of $12 / 04 / 00$ & 2000 & $\begin{array}{l}\text { Appointment of current members of } \\
\text { the Collège }\end{array}$ \\
\hline & $\begin{array}{l}\text { Conventions between the Government of Chad } \\
\text { and the BEAC }\end{array}$ & & \\
\hline 12 & $\begin{array}{l}\text { Convention of } 11 / 27 / 03 \text { governing the } \\
\text { Distribution Account No } 41234 \text { at the BEAC }\end{array}$ & 2003 & $\begin{array}{l}\text { Until 12/31/07: } 80 \text { percent of } \\
\text { royalties and } 85 \text { percent of dividends } \\
\text { in an stabilization account; the } 15 \\
\text { percent of dividends and royalties in } \\
\text { the Treasury account at the BEAC, } \\
\text { and the } 5 \text { percent of royalties the }\end{array}$ \\
\hline
\end{tabular}




\begin{tabular}{|c|c|c|c|}
\hline & & & $\begin{array}{l}\text { account for the producing region. } \\
\text { After } 12 / 31 / 07: 95 \text { percent of } \\
\text { royalties and } 100 \text { percent of dividends } \\
\text { in the stabilization account, and } 5 \\
\text { percent in the producing region } \\
\text { account. }\end{array}$ \\
\hline 13 & $\begin{array}{l}\text { Convention of } 11 / 27 / 03 \text { governing the } \\
\text { Stabilization Account No. } 43202 \text { at the BEAC. }\end{array}$ & 2003 & $\begin{array}{l}\text { Quarterly disbursement in line with } \\
\text { approved expenditure in the oil } \\
\text { budget. }\end{array}$ \\
\hline 14 & $\begin{array}{l}\text { Convention of } 11 / 27 / 03 \text { governing the Producing } \\
\text { Region Account No. } 43203 \text { at the BEAC. }\end{array}$ & 2003 & $\begin{array}{l}\text { Withdraws can be made only by the } \\
\text { local authorities or by the Provisional } \\
\text { Committee established by Decree } \\
457 .\end{array}$ \\
\hline \multirow[t]{2}{*}{15} & $\begin{array}{l}\text { Convention governing the Modalities for the } \\
\text { Management by the BEAC of the Funds for } \\
\text { Future Generations. }\end{array}$ & 2005 & \\
\hline & Loan Agreements & & \\
\hline 16 & $\begin{array}{l}\text { Loan Agreement of 03/29/2001 between the } \\
\text { Republic of Chad and the IBRD }\end{array}$ & 2001 & $\begin{array}{l}\text { Annex } 5 \text { contains the rules governing } \\
\text { the management, distribution, and use } \\
\text { of various types of resources. }\end{array}$ \\
\hline 17 & $\begin{array}{l}\text { General Conditions Applicable to Loan and } \\
\text { Guarantee Agreements of } 01 / 01 / 85 \text { as amended } \\
\text { through } 10 / 06 / 99\end{array}$ & 1999 & \\
\hline \multirow[t]{2}{*}{18} & $\begin{array}{l}\text { General Conditions Applicable to Loan Guarantee } \\
\text { Agreements for Single Currency Loans of } \\
05 / 30 / 95 \text { as amended through 10/06/99 }\end{array}$ & 1999 & $\begin{array}{l}\text { Sets forth the terms and conditions } \\
\text { applicable to the Loan Agreement and } \\
\text { the Guarantee Agreement, to the } \\
\text { extent and subject to any } \\
\text { modifications set forth in such } \\
\text { agreements. }\end{array}$ \\
\hline & $\begin{array}{l}\text { Escrow Agreement, Account Protocol, and } \\
\text { Schedule of Fees for Services as Account Bank } \\
\text { for the Chad-Cameroon Pipeline Project }\end{array}$ & & \\
\hline \multirow[t]{2}{*}{19} & $\begin{array}{l}\text { Agreements of } 06 / 15 / 01 \text { between the IBRD, the } \\
\text { EIB, the Government of Chad, and the Citibank } \\
\text { establishing the conditions under which the EIB, } \\
\text { the IBRD, the Government of Chad, and Citibank } \\
\text { shall operate the Transit and Escrow Accounts. }\end{array}$ & 2001 & $\begin{array}{l}\text { In particular, it regulates the transfers } \\
\text { from the Transit Account to the } \\
\text { Escrow Accounts to cover the next } \\
\text { payment due on loans granted by the } \\
\text { World Bank and the European } \\
\text { Investment Bank. }\end{array}$ \\
\hline & Agreements with domestic commercial banks & & \\
\hline 20 & $\begin{array}{l}\text { Conventions of } 06 / 14 / 04 \text { governing the Treasury } \\
\text { accounts at the SGTB and the CBT for the } \\
\text { management of oil revenue }\end{array}$ & 2004 & $\begin{array}{l}\text { Establishes management procedures } \\
\text { for the special Treasury accounts in } \\
\text { the commercial banks. }\end{array}$ \\
\hline
\end{tabular}


Annex II. Applying a Permanent Income Hypothesis (PIH) to Chad

51. The permanent income hypothesis (PIH) postulates that total oil wealth-the sum of both oil wealth underground and financial wealth-has to remain constant in real terms over time. Using this policy rule, the government would use in fiscal year $t$ only the sustainable income $\left(S I_{t}\right)$, which is the maximum amount that can be appropriated from oil savings in that fiscal year and still leave enough savings for an amount equal to the real value to be appropriated in all later fiscal years.

$$
S I_{t}=r_{t} . O W_{t}
$$

where $r_{t}$ is the estimated average real rate of return (the real interest rate) on investment of oil deposits in the future, and $O W_{t}$ is the oil wealth, which is estimated as:

$$
O W_{t}=O S_{t}+N P V\left(O R_{0}, O R_{1 \ldots O R_{2030}}\right)
$$

where $O S_{t}$ is the stock of oil savings at the end of the fiscal year $t$, and $O R_{t}$, the projected oil revenue.

Chad: Long-Term Fiscal Policy under a Permanent Income Hypothesis 2006-2030

\begin{tabular}{lrrrrrr}
\hline & 2006 & 2007 & 2010 & 2020 & 2030 & $2007-2030^{2 /}$ \\
\hline & & & & & & \\
+ Non-oil revenue & 8.5 & 8.7 & 8.9 & 8.9 & 8.9 & 8.9 \\
+ Sustainable Income & 6.4 & 5.2 & 4.6 & 2.2 & 1.0 & 2.7 \\
- Debt service & 2.2 & 2.1 & 1.2 & 0.8 & 0.8 & 1.0 \\
- Other financing items & 1.5 & 0.9 & 0.4 & 0.0 & 0.0 & 0.2 \\
- Domestically Financed Primary Expenditure & 25.9 & 10.8 & 11.9 & 10.3 & 9.1 & 10.4 \\
Sustainable Non-oil primary balance & $\mathbf{- 1 6 . 6}$ & $\mathbf{- 2 . 1}$ & $\mathbf{- 3 . 0}$ & $\mathbf{- 1 . 4}$ & $\mathbf{- 0 . 1}$ & $\mathbf{- 1 . 6}$ \\
Oil revenue account balance & 3.2 & 28.7 & 34.5 & 52.4 & 33.8 & 43.2 \\
\hline
\end{tabular}

Sources: Fund staff estimates.

$1 /$ Percentage of non-oil GDP.

2/ Average.

52. Because Chad's oil wealth is relatively small, applying the PIH would allow for only a very low expenditure ratio over time. Under the PIH, oil wealth will be gradually transformed into financial wealth, which in turn will make it possible to derive an income stream to keep government spending stable over the long term. As oil resources are exploited and the value of oil in the ground declines, a fraction of the oil wealth needs to be saved and turned into financial wealth so as to keep total oil wealth constant. The advantage of this rule is that it captures the full value of oil wealth - oil in the ground as well as financial wealthand it enables society to benefit permanently from its use. Assuming that non-oil revenue remains at about the current 8 to 9 percent of non-oil GDP, the PIH would require that the expenditure ratio be reduced from the current 26 percent of non-oil GDP to 11 percent starting in 2007. 
Chad: Long-Term Fiscal Policy under a Permanent Income Rule 2007-2030

Net Financial Wealth (in percent of non-oil GDP)

Government Primary Domestically Financed Spending

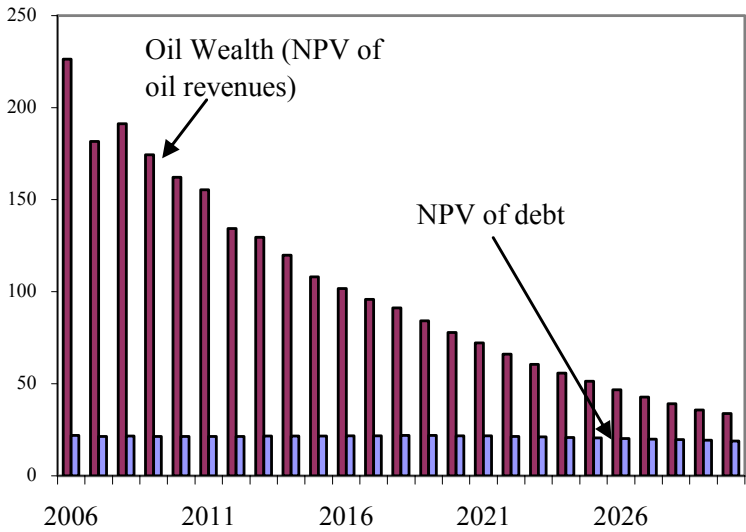

(in percent of non-oil GDP)

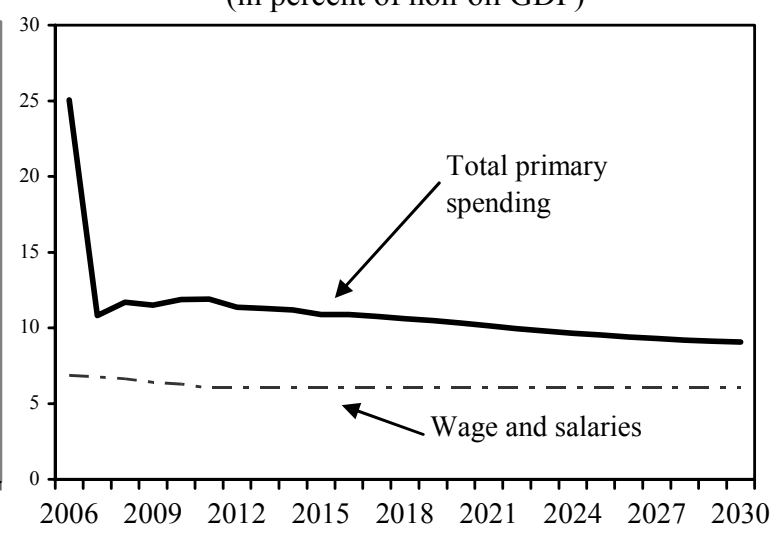

Chad: Long-Term Government Finances (Percent of non-oil GDP)

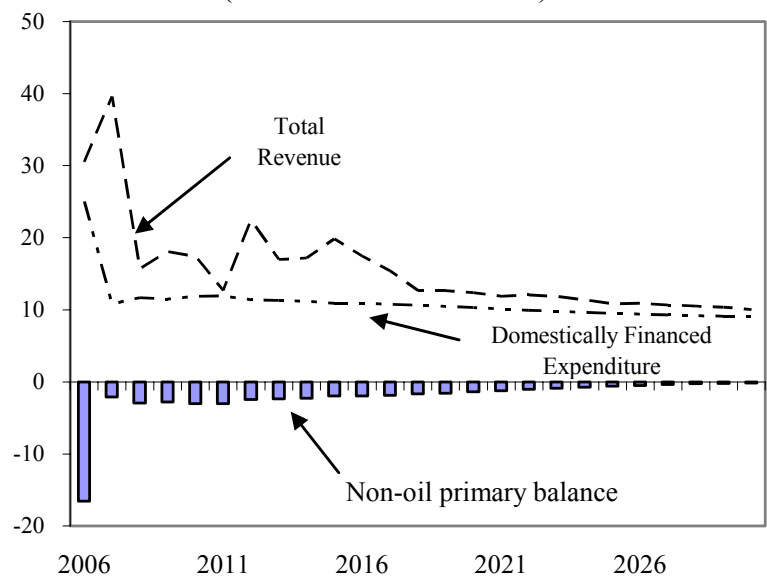

Chad: Tax Ratio and Saving (Percent of non-oil GDP)

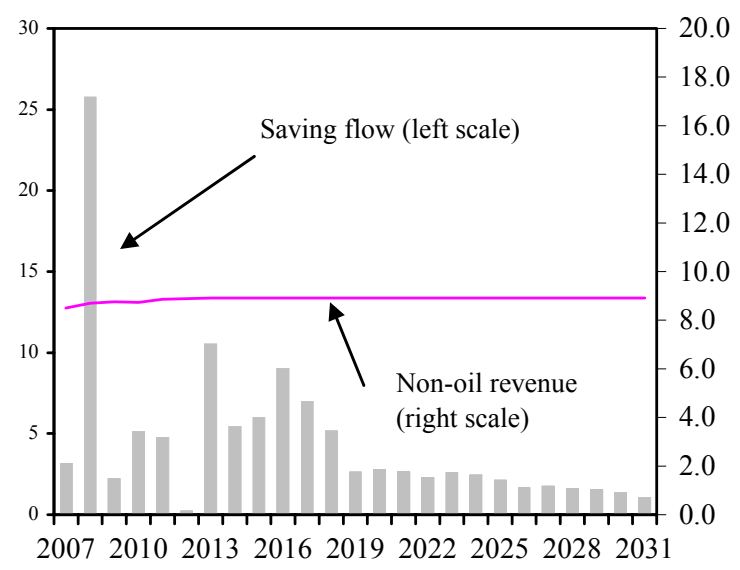

Source: Chadian authorities; and IMF staff estimates and projections. 


\section{Civil And Military Service Reform in Chad ${ }^{60}$}

\section{A. Introduction}

1. Civil and military service reform in Chad is essential for strengthening public administration, in particular as regard policy formulation and reform implementation capacity, and improving governance. Such reforms would help improve Chad's reform execution and thus strengthen its macroeconomic performance. ${ }^{61}$ The military service, which accounts for about 40 percent of public employment, should also be modernized. This paper assesses the implementation of civil and military ${ }^{62}$ service reforms, describes the main features of the civil and military services, and provides reform recommendations.

\section{The main findings of the paper are as follows:}

- $\quad$ Despite being part of Chad's structural reform agenda since the mid-1990s, civil and military service reforms have made little progress, largely owing to weak government ownership of such reforms, poor coordination among institutions charged with the reform, inappropriate sequencing of related actions, and lack of financing. As a result, the quality of public administration remains poor.

- The composition of Chad's public employment is not in line with the government's poverty reduction strategy. Indeed, education and health staffing as a share of the total population is well below regional standards.

- $\quad$ Personnel management does not adequately support performance or safequard the quality of public service delivery because recruitment practices, promotion criteria, and the wage structure are not tied to skills or performance, and the civil and military services lack the basic tools needed to manage human resources.

- $\quad$ The wage bill absorbs a significant share of non-oil revenue and current spending. This absorption of non-oil resources, combined with Chad's weak and complex financial management system, contributed to the emergence of wage arrears in 2005.

- $\quad$ To improve the quality of institutions and governance and ensure the sustainability of the fiscal outlook, it is urgent that the government accelerate the implementation of both the civil service statute and its strategic human resources management policies, particularly in education, health, and other priority sectors. In addition, by computerizing and harmonizing the payroll and personnel management systems and

\footnotetext{
${ }^{60}$ Prepared by Sarah Lacoche.

${ }^{61}$ As called for in the recent Ex Post Assessment of Performance under ESAF/PRGF Programs, Country Report No. $04 / 111$.

${ }^{62}$ This paper provides a general overview of military service reform.
} 
implementing military personnel reform, the government would strengthen its cash management practices.

3. This paper is organized as follows. Section B presents the reform strategy and takes stock of its implementation. Section C describes the main characteristics of Chad's wage bill and civil service management. Section D offers recommendations.

\section{Civil and Military Service Reform Strategy, Implementation}

4. The main goals of the civil and military service reform - adopted by the government in 1998 - are to:

- $\quad$ improve government effectiveness and service delivery, particularly in achieving poverty reduction;

- $\quad$ strengthen civil service management by implementing an integrated personnel management and payroll system and by streamlining pay and career structures;

- $\quad$ ensure that the wage bill remains consistent with a sustainable framework and that workers receive wages on time; and

- $\quad$ reform the military's structure, wage level, and personnel management system to improve security and efficiency.

5. The civil service reform strategy has four pillars: (i) improve the quality of human resources, (ii) provide adequate incentives and a productive working environment, (iii) increase the accountability of staff to beneficiaries; and (iv) establish transparent staff rules, regulations, and records. The reform mandated an audit of ministries, adoption of a new civil service statute, and the development of a computerized system for payroll and personnel management. The World Bank, which has taken the lead in assisting Chad in its civil service reform, is supporting the government's efforts to strengthen governance and public resources management ${ }^{63}$ through the Institutional Reform Support Credit approved in November 2004.

6. After the government adopted the strategy in 1998, the authorities implemented a number of actions. An institution in charge of civil service reform implementation (CESRAP) was set up in 1999. A census of civil personnel was completed in 2000. In 2001,

\footnotetext{
${ }^{63}$ These measures amount to a second generation of civil service reforms (Ul Haque and Aziz, 1998). The first generation focused on containing budgetary costs, particularly wages, to address fiscal constraints, while second-generation reforms aim to improve the quality of the public sector, which allows the state "to pursue its objective in the most efficient way" and to better implement public sector policies (Tanzi, 2000).
} 
the authorities adopted a new civil service statute that applies merit-based criteria to recruitment, promotion, and pay practices, and the government simplified and computerized the payroll tracking system. In 2003, an audit was completed on the institutional organization and personnel management policies of nine key pilot ministries (Box 1). To support the goals of the National Poverty Reduction Strategy (NPRS), the government's recruitment policy has concentrated on hiring personnel in priority sectors (Table 1), financed in part by using a portion of oil revenues received since 2004 .

Table 1: Chad: Recruitments in selected priority sectors, 2000-06

(In number of staff, unless otherwise indicated)

\begin{tabular}{|c|c|c|c|c|c|c|c|}
\hline & $\begin{array}{r}2000 \\
\text { Act. }\end{array}$ & $\begin{array}{r}2001 \\
\text { Act. }\end{array}$ & $\begin{array}{r}2002 \\
\text { Act. }\end{array}$ & $\begin{array}{r}2003 \\
\text { Act. }\end{array}$ & $\begin{array}{r}2004 \\
\text { Act. }\end{array}$ & $\begin{array}{r}2005 \\
\text { Est. }\end{array}$ & $\begin{array}{l}2006 \\
\text { Proj. }\end{array}$ \\
\hline $\begin{array}{l}\text { Net recruitment } 1 / \\
\text { Of which: }\end{array}$ & 1,452 & 2,356 & 2,152 & 2,998 & 1,733 & 5,277 & 5,623 \\
\hline Education & 589 & 1,098 & 332 & 1,208 & 866 & 1,436 & 1,885 \\
\hline Health & 13 & 23 & 228 & 301 & 261 & 390 & 190 \\
\hline Social Affairs & 84 & 35 & 26 & 26 & 87 & 55 & 65 \\
\hline Justice & 61 & 9 & 142 & 113 & 147 & 65 & 551 \\
\hline $\begin{array}{l}\text { Selected priority sectors as a } \\
\text { percentage of total recruitments }\end{array}$ & 51.4 & 49.4 & 33.8 & 55.0 & 78.5 & 36.9 & 47.9 \\
\hline Total employment & $\ldots$ & 57,167 & 59,319 & 62,317 & 65,800 & $\ldots$ & 84,950 \\
\hline Civil & 29,811 & 32,167 & 34,319 & 37,317 & 39,050 & 44,327 & 49,950 \\
\hline Military & $\ldots$ & 25,000 & 25,000 & 25,000 & 26,750 & $\ldots$ & 35,000 \\
\hline
\end{tabular}

Sources: Chadian authorities

1/ Central government, excluding defense. 


\section{Box 1. Chad: Main Conclusions of the Audit of Nine Key Ministries}

In 2003, an institutional and organizational audit of nine key ministries (Finance; Planning, Development, and Cooperation; Education; Higher Education; Health; Social Action and Welfare; Agriculture; Livestock; and Justice) revealed:

(i) institutional conflicts between ministries, owing to a lack of clear organizational responsibilities (e.g., between the Ministry of Finance and the Ministry of Planning on public investment roles);

(ii) weak ownership over sector strategies and Poverty Reduction Strategy measures;

(iii) a lack of human resources management policies and tools; and

(iv) lack of a performance-based management system.

7. However, reform implementation has been slow and uneven, reflecting three factors: poor coordination among the institutions in charge of implementing the measures, inappropriate sequencing of actions, and weak government ownership of the reforms. Most of the implementation decrees of the new statute have not yet become effective, so that many features of the 1986 civil service statutes have prevailed. ${ }^{64}$ Wages and recruitment are still determined by ad hoc procedures, and some civil servants are recruited on a contractual basis. The new three-level performance-based wage structure is not yet operational, as civil servant unions have blocked operational regulations. The computerized personnel and payroll system could not be finalized before the census was completed and thus draws on outdated census data. Moreover, the computerized system itself has no reliable back-up procedures and is not properly maintained. Finally, the CESRAP, as a purely "technical body," lacks political support for implementing the reform. In the context of high unemployment and corruption, ${ }^{65}$ rent-seeking behavior has hindered reform implementation.

\section{A reform of the military personnel management prepared in 1996 could not be} implemented until 2005 because of financing shortfalls. By addressing issues related to wages, personnel structure, and status, the reform would help improve security, a goal identified as a priority for poverty reduction under the NPRS. Indeed, in the past, some demobilized military personnel were not smoothly reinserted into society and contributed to domestic insecurity. Therefore, provision of an adequate remuneration package to military personnel was identified as key to security and political stability. As shown in Table 2, civil service wages at the end of 2004 were estimated to be two to three times higher than military

\footnotetext{
${ }^{64}$ In addition to noncompetitive hiring procedures, recruitment efforts do not match skills with job requirements, $d$ promotions are based on time-in-grade rather than on performance, and educational degree. rather than job responsibility, determines the wage level.

${ }^{65}$ In 2005, Transparency International ranked Chad (along with Bangladesh) as the most corrupt country in terms of perceived level of corruption among a sample of 159 countries.
} 
wages under the lump-sum system. The military personnel structure, which has a disproportionate share of high-ranking officers, does not reward performance, and ethnic imbalances in the composition of army staff have sparked tensions.

Table 2: Chad: Givil and military personnel wages

Estimated average monthly wage in thousands of CFA francs in 2004

\begin{tabular}{lrr}
\hline & Military Personnel & Givil personnel \\
& & \\
Grade A & 111 & 246 \\
Grade B & 59 & 155 \\
Grade C & 38 & 125 \\
\hline
\end{tabular}

Sources: Chadian authorities; staff estimates.
Chad: Structure of military personnel

\begin{tabular}{|c|}
\hline $\begin{array}{c}\text { Grade A, } \\
31 \%\end{array}$ \\
\hline $\begin{array}{c}\text { Grade B, } \\
33 \%\end{array}$ \\
\hline $\begin{array}{c}\text { Grade C, } \\
35 \%\end{array}$ \\
\hline
\end{tabular}

\section{A General Assembly of the Army in April 2005 designed a new statute and} discussed issues pertaining to the management of military personnel. Objectives of the reform include limiting the army to 25,000 staff, increasing wages and benefits, establishing a more merit-based promotion system, and ensuring the reinsertion of demobilized officers. ${ }^{66}$ Given the government's financing constraints, the reform has not yet been fully implemented, though the replacement of the lump-sum system with a pay-scale system in January 2005 more closely aligned military wages with those of the civil service. Both France and the World Bank are expected to provide technical assistance to help the authorities finalize their security sector reform program, including through a demobilization program. However, it will be difficult to implement a comprehensive security reform program in the current insecurity context.

\footnotetext{
${ }^{66}$ Reinsertion programs have yet to be specified. Agriculture and livestock were identified as potential reinsertion sectors.
} 


\section{Main Characteristics of Chad's Civil and Military Service}

\section{Chad's public employment is small compared with that of other sub-Saharan} African and low-income countries, and its composition differs markedly from peergroup countries' (Table 3). Public employment in Chad only accounts for 0.81 percent of the total population, below the averages for both sub-Saharan African countries (1.5 percent) and low-income countries (2.6 percent). However, armed forces (police and defense) as a share of the total population ( 0.4 percent) is higher than the average in sub-Saharan countries, and staffing in such priority sectors as health and education is much lower than the subSaharan average (Table 4), a gap that contributes to poor service delivery. Civil service workers also tend to be heavily concentrated in urban areas (60 percent work in N'Djamena, where just 10 percent of the total population live), not in rural areas, where most of the poor live. There are few incentives to work in provinces, where poor infrastructure, security concerns, and late wage payments create challenging working conditions. Recruitment in priority sectors has improved somewhat in recent years, with priority sector staffing accounting for a rising percentage of the total population. However, the quality of service delivery in priority sectors still remains very low (see Box 2).

Table 3. Chad: Public sector employment and wages, 1996-2000

\begin{tabular}{|c|c|c|c|}
\hline & Chad & Sub Saharan Africa & Low income group \\
\hline \multicolumn{4}{|c|}{ As a percentage of total population (unless otherwise indicated) } \\
\hline Civilian government, excluding health, education and police & 0.24 & 0.30 & 0.46 \\
\hline Education employees & 0.13 & 0.62 & 0.91 \\
\hline Health employees & 0.04 & 0.29 & 0.62 \\
\hline Police & 0.06 & 0.07 & 0.30 \\
\hline Armed forces & 0.34 & 0.26 & 0.33 \\
\hline Total & 0.81 & 1.54 & 2.62 \\
\hline Total government wage (as a percentage of GDP) & 4.62 & 6.09 & 5.43 \\
\hline Total government wage (as a percentage of expenditures) & 25.6 & 28.9 & 24.7 \\
\hline
\end{tabular}

Source: World Bank, Fund staff and authorities estimates 


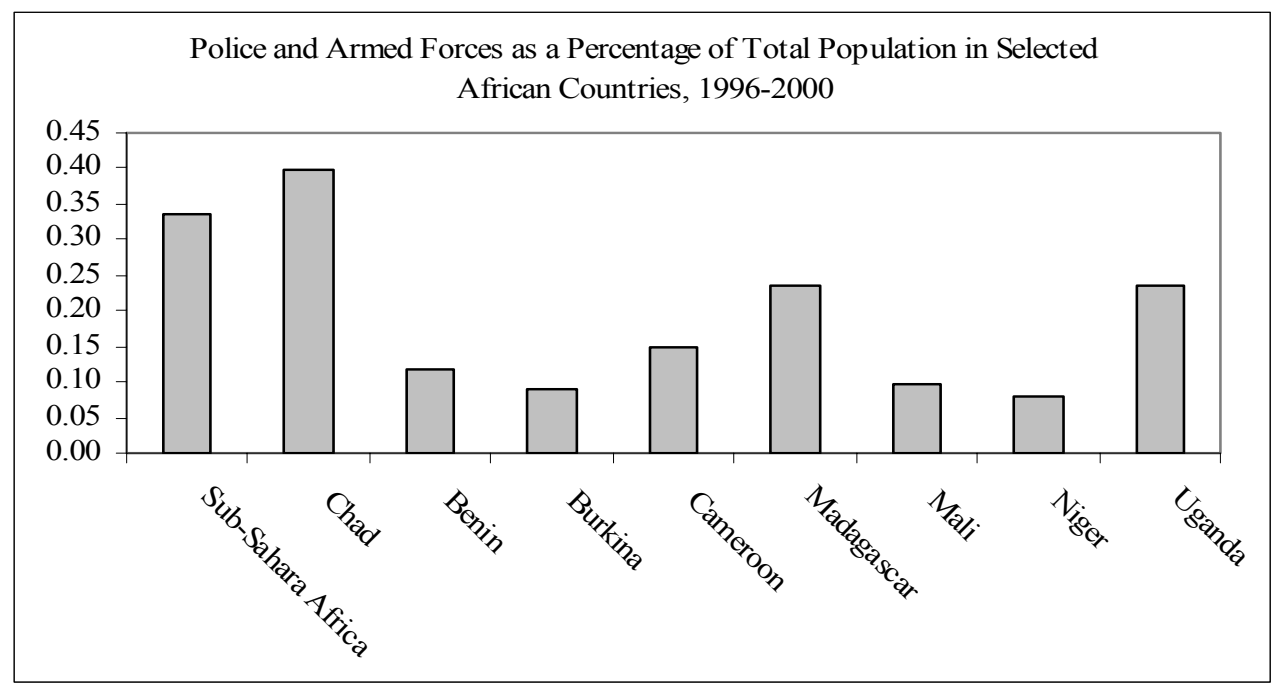

Employees as a percentage of total population, 1996-2000
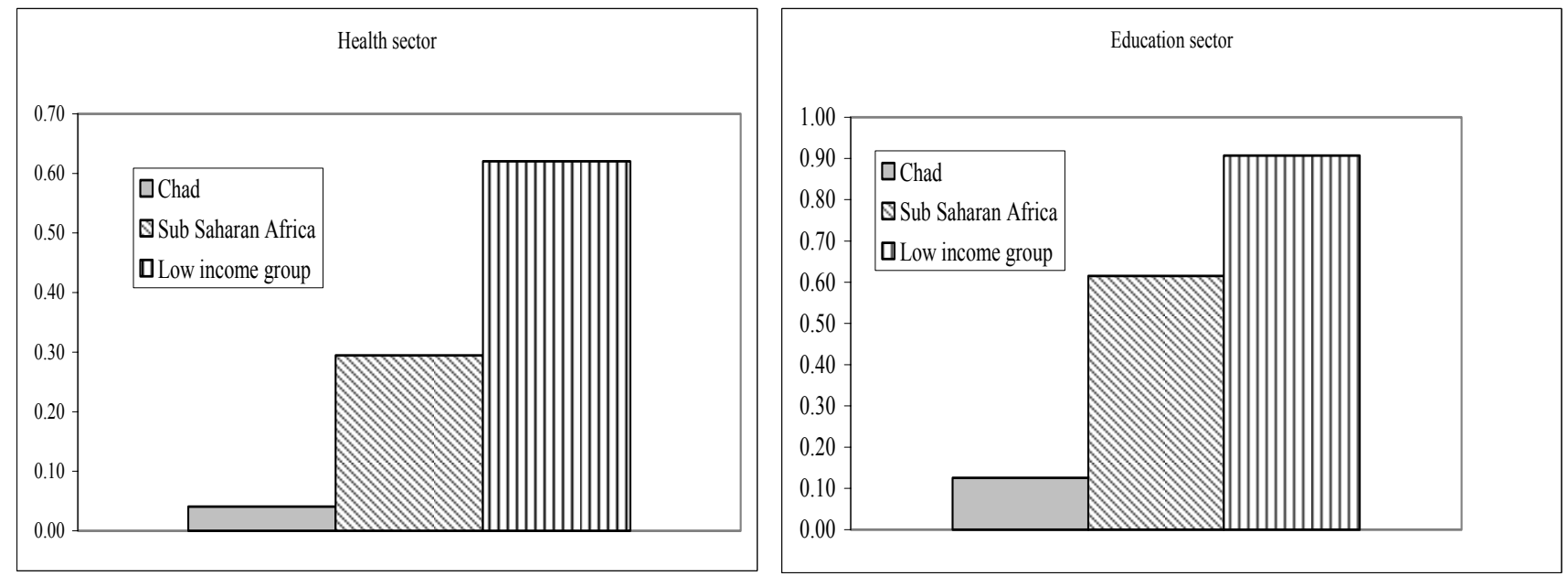

Table 4. Chad: Staffing of education and health sectors

$1996-2000$

2002

2003

$2004 \quad 2005$

2006

As a percentage of total population (unless otherwise indicated)

Education

\begin{tabular}{lccccccc} 
Chad & 0.13 & 0.15 & 0.15 & 0.15 & 0.16 & 0.17 & 0.18 \\
$\quad$ Sub-Saharan Africa & 0.62 & $\ldots$ & $\ldots$ & $\ldots$ & $\ldots$ & $\ldots$ & $\ldots$ \\
$\quad$ Lowincome group & 0.62 & $\ldots$ & $\ldots$ & $\ldots$ & $\ldots$ & $\ldots$ & $\ldots$ \\
Health & & & & & & & \\
Chad & 0.04 & 0.04 & 0.04 & 0.04 & 0.04 & 0.05 & 0.05 \\
Sub-Saharan Africa & 0.29 & $\ldots$ & $\ldots$ & $\ldots$ & $\ldots$ & $\ldots$ & $\ldots$ \\
Lowincome group & 0.62 & $\ldots$ & $\ldots$ & $\ldots$ & $\ldots$ & $\ldots$ & $\ldots$ \\
\hline
\end{tabular}

Source: World Bank, Fund staff and authorities estimates 
11. The wage bill as a share of GDP is in line with other African countries', but it absorbs a significant portion of non-oil revenue; this absorption of resources, in the context of weak cash management practices and complex system, has contributed to the emergence of recurrent wage arrears in 2005. The wage bill as a share of non-oil GDP increased from 4.6 percent in 2001 to 6.0 percent in 2005, absorbing about 60 percent of 2005 non-oil revenue, or 50 percent of current expenditures (Table 5). Because the 2005 budget earmarked oil revenue to capital expenditures, such revenue could not be used to finance timely wage payments in priority sectors. Shortfalls in non-oil receipts, combined with weak cash and budget management, thus gave rise to the accumulation of wage arrears of about two months at the end of September 2005, sparking significant social and political tensions. Notably, the timeliness of wage payments has improved since the end of 2005, when greater timeliness was identified as a priority in cash management.

12. Because the legal basis of the new statutes is still incomplete, competitive recruitment, merit-based remuneration, and performance-based promotion practices have not been widely adopted. Across-the-board wage increases in 2003 and 2004 went against the spirit of the reform. The government announced a further 5 percent general civil service wage increase in mid-2006, despite poor strategic human resources planning and weak coordination between the ministry overseeing the civil service and its line ministries. High staff turnover also continues to weaken the quality of civil service administration.

13. Personnel and payroll management systems remain weak. A comprehensive, computerized, and up-to-date database on civil personnel (including job profiles, grades, and related salary and allowances) has yet to be created. Further, manually maintained personnel and payroll files have yet to be harmonized, resulting in important inconsistencies. The payroll file also still reflects the old wage structure, which includes 11 staff categories. Finally, inadequate payroll monitoring tools and the absence of payroll data in the computerized budget execution system continue to hamper the monitoring of wage payments. 
Table 5: Chad: Basic data on civil and military personnel and wages, 2001-2006 1/

\begin{tabular}{|c|c|c|c|c|c|c|}
\hline & 2001 & 2002 & 2003 & 2004 & 2005 & 2006 \\
\hline & Est. & Est. & Est. & Est. & Prel. Est. & Proj. \\
\hline \multicolumn{7}{|l|}{ Public Sector Employment } \\
\hline Central Govemment & $57,167.0$ & $59,319.0$ & $62,317.0$ & $65,800.0$ & $69,327.0$ & $84,950.0$ \\
\hline Givil personnel & $32,167.0$ & $34,319.0$ & $37,317.0$ & $39,050.0$ & $44,327.0$ & $49,950.0$ \\
\hline \multicolumn{7}{|l|}{ Ofwhich: } \\
\hline Education & $11,259.0$ & $11,591.0$ & $12,799.0$ & $13,665.0$ & $15,101.0$ & $16,986.0$ \\
\hline Health & 2917.0 & $3,145.0$ & $3,446.0$ & $3,707.0$ & $4,097.0$ & $4,287.0$ \\
\hline Defense & $25,000.0$ & $25,000.0$ & $25,000.0$ & $26,750.0$ & $25,000.0$ & $35,000.0$ \\
\hline Subnational Covemment & $\ldots$ & $\ldots$ & $\ldots$ & $\ldots$ & $\ldots$ & $\ldots$ \\
\hline \multicolumn{7}{|l|}{ Ratio as a percentage of central government personnel } \\
\hline Gvil personnel & 56.3 & 57.9 & 59.9 & 59.3 & 63.9 & 58.8 \\
\hline Defense & 43.7 & 42.1 & 40.1 & 40.7 & 36.1 & 41.2 \\
\hline Central government staff per capita (as a percentage of population) & 0.7 & 0.8 & 0.7 & 0.7 & 0.8 & 0.9 \\
\hline Education & 0.1 & 0.1 & 0.1 & 0.2 & 0.2 & 0.2 \\
\hline Health & 0.0 & 0.0 & 0.0 & 0.0 & 0.0 & 0.0 \\
\hline Defense & 0.3 & 0.3 & 0.3 & 0.3 & 0.3 & 0.4 \\
\hline \multicolumn{7}{|l|}{ Public employee vages (central government) } \\
\hline Wages (in CFAF billions) & 56.7 & 62.1 & 73.6 & 80.1 & 101.2 & 123.7 \\
\hline Gvil service & 44.3 & 48.9 & 56.2 & 60.9 & 73.3 & 89.0 \\
\hline Defense & 12.4 & 13.2 & 17.4 & 19.2 & 27.9 & 34.7 \\
\hline Wage bill as a share of GDP & 4.5 & 4.5 & 4.6 & 3.4 & 3.3 & 3.6 \\
\hline Wage bill as a share of non-oil GDP & 4.6 & 4.6 & 5.4 & 5.7 & 6.1 & 6.9 \\
\hline Wage bill as a share of total spending & 25.7 & 22.2 & 21.1 & 23.8 & 25.0 & 20.0 \\
\hline Wage bill as a share of current expenditures & 51.6 & 44.4 & 49.2 & 51.8 & 54.0 & 35.0 \\
\hline Wage bill as a share of non-oil revenue, excluding grants & 61.8 & 55.2 & 59.0 & 57.1 & 63.5 & 73.4 \\
\hline \multicolumn{7}{|l|}{ Wage level } \\
\hline Average annual public sector wage in thousands of CFA francs & 991.6 & $1,047.1$ & $1,180.5$ & $1,217.8$ & $1,459.6$ & $1,456.5$ \\
\hline Gvil personnel & $1,377.1$ & $1,424.6$ & $1,505.9$ & $1,559.3$ & $1,653.3$ & 1,7826 \\
\hline Defense & 495.5 & 528.9 & 694.9 & 719.4 & $1,116.1$ & 991.1 \\
\hline Average public sector wage as a share of GDP per capita & 6.1 & 5.9 & 6.4 & 4.6 & 4.2 & 3.9 \\
\hline \multicolumn{7}{|l|}{ Compression ratio $2 /$} \\
\hline Gvil personnel (average between category A and C) & $\ldots$ & $\ldots$ & $\ldots$ & $\ldots$ & 2.0 & $\ldots$ \\
\hline Defense & $\ldots$ & $\ldots$ & $\ldots$ & 2.9 & $\ldots$ & $\ldots$ \\
\hline \multicolumn{7}{|l|}{ Share as a percentage of central govemment wage bill } \\
\hline Givil service & 78.1 & 78.7 & 76.4 & 76.0 & 72.4 & 72.0 \\
\hline Defense & 21.9 & 21.3 & 23.6 & 24.0 & 27.6 & 28.0 \\
\hline \multicolumn{7}{|l|}{ Memorandumitem: } \\
\hline & \multicolumn{6}{|c|}{ (In billions of FA francs, unless otherwise indicated) } \\
\hline GDP & $1,253.0$ & $1,385.3$ & $1,582.4$ & $2,332.3$ & $3,104.4$ & $3,420.5$ \\
\hline Non-oil GDP & $1,229.4$ & $1,341.9$ & $1,363.3$ & $1,412.1$ & $1,652.5$ & $1,804.2$ \\
\hline Total expenditures & 220.3 & 280.3 & 348.0 & 336.8 & 404.9 & 617.5 \\
\hline Total current expenditures & 109.8 & 140.0 & 149.4 & 154.7 & 187.3 & 353.8 \\
\hline Non-oil revenue, excluding grants & 91.7 & 112.4 & 124.6 & 140.3 & 159.2 & 168.6 \\
\hline Population (in million) & 7.7 & 7.9 & 8.6 & 8.8 & 9.0 & 9.3 \\
\hline
\end{tabular}




\section{Box 2: Personnel Management in the Education Sector}

According to the World Bank, the share of nonteaching personnel in the education sector is higher than in other sub-Saharan African countries (Table 6).

Table 6: Chad: Non teaching personnel in the education sector in 2003

\begin{tabular}{lcr}
\hline & Chad & Other african countries 1/ \\
\hline Primary education & 18.0 & 14.7 \\
Secondary education & 33.0 & 29.0 \\
\hline Sources: World Bank. & & \\
1/ Cameroon, Madagascar, Mauritania, Niger, and Togo.
\end{tabular}

Although wage and nonwage costs are higher than in other sub-Saharan African countries, the quality of service in Chad (e.g., supervision rate by teacher) is low (Table 7).

Table 7: Chad: Some international comparisons for the education sector (2003)

\begin{tabular}{lrr}
\hline & Chad & Other african countries 1/ \\
\hline Primary education & 72.0 & 47.7 \\
Ratio pupils per teacher & 7.2 & 4.6 \\
Wage/ GDP per capita & 44.9 & 31.1 \\
Expenditures excluding teachers' wages & & \\
\hline Sources: World Bank, UNESCO/BREAD, Pole de Dakar. & \\
1/ Burkina Faso, Benin, Cameroon, Ivory Coast, Guinea, Madagascar, Mauritania, \\
Niger, and Togo.
\end{tabular}

There is a two-speed personnel system between community teachers (who are hired and paid by parents) and civil servants. Despite the implementation of a subsidy system in 2001 (funded by Heavily Indebted Poor Country Initiative resources and, since 2005, by earmarked oil revenue), significant wage disparities between civil servants and community teachers persist (Table 8). In addition, subsidies do not always reach beneficiaries because the HIPC budget has been systematically underfunded or funds have been used for other purposes at the local level. There is a plan to elaborate a specific civil service status for community teachers in 2007.

Table 8: Chad: Wage disparities in primary education (2003)

\begin{tabular}{lrr}
\hline & $\begin{array}{c}\text { Monthly wage in } \\
\text { CFA franc }\end{array}$ & Distribution \\
\hline 1. Community teacher (average) & 4,992 & 44 \\
2. Subsidized community teachers (no training) & 25,000 & 17 \\
3. Subsidized community teachers (with training) & 45,000 & $\ldots$ \\
4. Category B teacher & 87,500 & 16 \\
5. Category C teacher & 120,000 & 22 \\
6. Contractual teachers & $\ldots$ & 1 \\
Memorandum item: & & \\
$\quad$ Compression ratio (5/1) & 24 \\
\hline Sources: World Bank.
\end{tabular}


14. Wage disparities do not appear related to either skills or job descriptions but rather to ad hoc nonwage benefits granted to specific categories. Although the

compression ratio, based on the average wage between category A and C, is only 2 (Table 9), there appears to be large same-grade disparities between ministries, with priority sector workers receiving lower pay (Table 10). The compression ratio is 6 for category A staff, while it is 17.4 for the highest paid category A staff and the lowest paid category C staff. Such large disparities make it difficult for some ministries to attract qualified staff. According to the theory of the fair wage-effort (Akerlof and Yellen,

Table 9: Chad: Compression ratios

\begin{tabular}{lr} 
Average monthly wage between Category A and C & 2.0 \\
Upper and lower bound in Category A & 6.0 \\
Upper and lower bound in Category B & 9.5 \\
Upper and lower bound in Category C & 9.0 \\
Upper bound from Category A and lower bound in Category C & 17.4 \\
\hline Sources: Chadian authorities; staff estimates.
\end{tabular}

Upper and lower bound in Category A $\quad 6.0$

Upper and lower bound in Category B $\quad 9.5$

Upper bound from Category A and lower bound in Category C $\quad 17.4$

1990), such disparities could prompt public workers to scale back their efforts to compensate for the difference between their actual wage and their "fair wage," an amount determined by equity and social exchange considerations.

Table 10: Chad: Structure of civil personnel wage bill. 1/

\begin{tabular}{|c|c|c|c|c|c|c|c|}
\hline Category & Number of staff & $\begin{array}{l}\text { Number of staff } \\
\text { as a percentage } \\
\text { of total staff }\end{array}$ & $\begin{array}{l}\text { Average monthly } \\
\text { wage in thousands } \\
\text { of CFA francs }\end{array}$ & $\begin{array}{l}\text { Upper } \\
\text { monthly wage } \\
\text { in thousands } \\
\text { of CFA } \\
\text { francs }\end{array}$ & Ministry & $\begin{array}{l}\text { Lower } \\
\text { monthly wage } \\
\text { thousands of } \\
\text { CFA francs }\end{array}$ & Ministry \\
\hline A & 6,827 & 24.8 & 246 & 1196 & Presidency & 199 & Communication \\
\hline B & 9,499 & 34.5 & 155 & 980 & Mediature & 104 & Security and immigration \\
\hline $\mathrm{C}$ & 6,742 & 24.5 & 125 & 617 & Presidency & 69 & Justice \\
\hline Others & 4,472 & 16.2 & 136 & 1026 & Presidency & 59 & Economy and Finance \\
\hline Total & 27,540 & 100.0 & 167 & & & & \\
\hline
\end{tabular}

Sources: Chadian authorities; staff estimates.

1/ Based on May 2005 data. 


\section{Recommendations}

\section{It is urgent that the government push ahead with the reform of its civil and military services through actions that:}

(i) Ensure fiscal sustainability. Chad's public wage bill as a share of GDP and the size of its civil services are within regional and international standards. However, the wage bill has continued to absorb an increasing share of non-oil revenue, and weak cash management practices have contributed to recurrent wage arrears. Thus, to ensure the timely payment of wages and to strengthen payroll management, any wage increase must be carefully evaluated, using sensitivity scenarios, against the potential risks to the fiscal outlook.

(ii) Strengthen personnel and payroll management. Related measures include finalizing the computerized integrated system for personnel and payroll management, backing up manually updated files, and strengthening the human resource management skills of the administrative and financial directorates. An update of the census, conducted as soon as possible, would ensure timely and accurate personnel information. Better coordination between the payroll and the Ministry of Finance would facilitate timely wage payments. Connecting the computerized integrated system to the computerized financial system for budget execution would support wage payment monitoring. Measures to strengthen budget and cash management would also ensure timely wage payments. ${ }^{67}$

(iii) Improve the quality of the provision of priority services and pro-poor spending. Given financial constraints, efforts to analyze staffing and training needs would be a wise first step. Some redeployment between sectors could be envisaged, but such efforts would need to be backed by financial incentives to account for ministry wage disparities. A comprehensive analysis of staffing needs should be conducted, given that redeployment and training could help limit new hiring. It is also important to better distribute staff in urban and rural areas using poverty maps. In the short term, it would likely be difficult to increase staff in rural areas; however, some incentives (such as accelerated promotion) could be readily implemented.

(iv) Strengthen the quality of institutions and governance. Upgrades to the CESRAP budget and human resources that aim to strengthen its monitoring role would improve governance. Regular, publicly available reports from the CESRAP on the implementation of reforms would enhance accountability. To strengthen government ownership of the reform and reinvigorate the reform process, a seminar could convene the Ministry of Labor, the Ministry of Finance, key line ministries, the Poverty Reduction Strategy Paper Committee, unions, and other civil society

\footnotetext{
${ }^{67}$ Most of these measure are part of the government action plan to strengthen public finance management, the PAMFIP (Plan d'Amélioration des Finances Publiques), but remains to be implemented.
} 
representatives to discuss civil service reform and how to schedule, coordinate, and finance its implementation. Since strengthening the oversight and accountability role of beneficiaries can often improve service delivery (Devarajan and Reitnikka, 2004), the reform strategy could also include demand-side measures, ${ }^{68}$ such as public service report cards, similar to those implemented in Bangalore, India, allowing beneficiaries to rate public services. Report card outcomes could then be linked to a performancebased personnel management system. It is also important to define and adopt a fair wage structure, which could help strengthen governance without increasing wages (Van Rijckeghem and Weder, 1997). For this purpose, a detailed review of benefits granted on top of the base salary could be conducted, and analytical work on the structure of a fair wage system in Chad could identify ways to reduce compression ratios.

${ }^{68}$ The demand-side approach focuses on engaging civil society and empowering communities for service delivery and could include such measures as initiating anticorruption activities to raise awareness and mobilize reform support and shifting service delivery resources with a focus on accountability. 


\section{References}

Akerlof, George A, Yellen, Janet.L., 1990 "The Fair-Wage Hypothesis and Unemployment," Quarterly Journal of Economics (US); 105:255-83

Devarajan, Shantayanan and Ritva Reitnikka, 2004 "Making Services Work for Poor People" Journal of African Economies, Volume 13 Supplement 1, pp. i142-i166

Tanzi, Vito, 2000, “The Role of the State and the Quality of the Public Sector," IMF Working Paper, WP/00/36 (Washington: International Monetary Fund).

Ul Haque, Nadeem and Jahangir Aziz, 1998 "The quality of governance: 'second-generation' civil service reform in Africa”, IMF Working Paper, WP/98/164 (Washington, International Monetary Fund)

Van Rijckeghem, Caroline and Beatrice Weder, 1997 "Corruption and the Rate of Temptation: Do low wages in the Civil Service Cause Corruption ?" IMF Working Paper WP/97/73, (Washington DC: International Monetary Fund) 


\section{ChAD's MicrofinANCE SECTOR: AN OVERVIEW ${ }^{69}$}

\section{A. Introduction}

1. Microfinance institutions (MFIs) have been successful in improving the population's access to financial services. Between 2000 and 2004, the microfinance sector grew rapidly: the number of MFIs doubled, the amount of credit extended by such institutions tripled, and their deposits increased sevenfold. This paper examines the status and development challenges of Chad's microfinance sector.

2. The paper's main findings are as follows:

A. Microfinance institutions (MFIs) have helped mobilize savings in Chad's informal sector, especially in rural areas. Compared with commercial banks, MFIs offer financial services to twice as many individuals as banks and are present in 20 times as many locations.

B. However, the microfinance sector in Chad still has limited macroeconomic significance. MFI deposits were equivalent to just 4 percent of commercial bank deposits and MFI loans to just 3 percent of commercial bank loans in 2004.

C. Important development barriers should be addressed to ensure that MFIs are a key ingredient of economic growth and poverty reduction. In particular, the sector's human resource and information technology systems need to be strengthened to promote more balanced — and sustainable — growth.

3. The paper is organized as follows. The next section describes the structure and regulatory environment of the microfinance sector in Chad. Section C examines how MFIs have helped increase access to credit and mobilize savings. Section D summarizes the main weaknesses and challenges of the country's MFI sector. Section E concludes and offers recommendations.

\section{B. Background}

4. Only a small segment of the Chadian population can access formal financial services. Chad has a very shallow financial market relative to its size $\left(1,284,000 \mathrm{~km}^{2}\right)$, with only five towns serviced by commercial banks. Only 0.7 percent of the population (about 60,000 people) have accounts with commercial banks. Deposits in the banking system account for only 4.5 percent of GDP (though the ratio of deposits to non-oil GDP, at 7 percent, is close to the average in the Central African Economic and Monetary Community (CEMAC)). The small portion of deposits in the money supply is further evidence of the limited role of Chad's formal banking system in Chad. In contrast to CEMAC countries,

\footnotetext{
${ }^{69}$ Prepared by Ngueto Yambaye and Teresa Dabán.
} 
where bank deposits account for about 75 percent of the average money supply, only 42 percent of Chad's money supply is intermediated through its banking system.

5. MFIs began developing in Chad in the 1980s, a period of growing interest in microfinance as a tool for mobilizing local savings, financing business activities, and supporting rural production through community-based financial intermediation. Chadian MFIs are grassroots savings and loan cooperatives (COOPECs), whose role is to mobilize local savings to allow communities to finance their own development. Of the MFIs, more than two-thirds operate within a network structure that provides them with technical and financial support. According to the Central African Banking Commission (COBAC), by end2004 Chad had 214 MFIs in three categories: (i) 187 MFIs organized in 6 networks, ${ }^{70}$ (ii) 23 independent MFIs; and (iii) 4 MFIs linked to foreign-financed development projects. Chad's MFIs operate in the banking and financial market segment, which is underserved by conventional banks and traditional financial institutions. Nonetheless, Chad's MFI and bank activities are complementary, in that highly local MFIs mobilize domestic savings, which then get partly deposited in commercial banks.

Table 1. Chad's MFI Sector, at June 30, 2004

\begin{tabular}{|c|c|c|c|c|c|c|c|c|}
\hline & \multicolumn{2}{|c|}{$\begin{array}{l}\text { Number of } \\
\text { MFIs }\end{array}$} & \multicolumn{2}{|c|}{$\begin{array}{l}\text { Number of } \\
\text { Members }\end{array}$} & \multicolumn{2}{|c|}{$\begin{array}{c}\text { Loans } \\
\text { (Millions of } \\
\text { CFAF) }\end{array}$} & \multicolumn{2}{|c|}{$\begin{array}{l}\text { Deposits } \\
\text { (Millions of } \\
\text { CFAF) }\end{array}$} \\
\hline & 2000 & 2004 & 2000 & 2004 & 2000 & 2004 & 2000 & 2004 \\
\hline $\begin{array}{l}\text { Networked } \\
\text { MFIs }\end{array}$ & 69 & 187 & 31,300 & 97,318 & 319 & 2,944 & 614 & 4,241 \\
\hline $\begin{array}{l}\text { Independent } \\
\text { MFIs and } \\
\text { projects }\end{array}$ & 7 & 27 & 579 & 1,060 & 1,064 & 725 & - & 178 \\
\hline Total & 76 & 214 & 31,879 & 98,378 & 1,383 & 3,669 & 614 & 4,419 \\
\hline
\end{tabular}

Source: Mission of the Commission Bancaire de l'Afrique Centrale for the Evaluation of the Microfinance Credit in Chad (November 2004-February 2005).

Table 2. MFIs Operating Within a Network Structure, 2004

\footnotetext{
${ }^{70}$ In 1993, a Chadian government project entitled "Grassroots Cooperative Development for Poverty Alleviation in Chad," financed by the United Nations Development Program, was established to alleviate the adverse impact of poverty. The project, which was driven by self-development groups, cooperatives, and mutual societies, included the setup of pilot savings and loan cooperatives in N'Djamena, designed to remedy the problem of scarce financial services and financial intermediation in and around the capital and serve as a model for the rest of the country. In 1996, this initiative spawned the Regional Union of Savings and Loan Cooperatives of Ndjamena (URCOOPEC) network, which had a membership of 10 MFIs, or COOPECs, by 2004.
} 


\begin{tabular}{|c|c|c|c|c|}
\hline & $\begin{array}{c}\text { Number of } \\
\text { MFIs }\end{array}$ & $\begin{array}{c}\text { Number of } \\
\text { Members }\end{array}$ & $\begin{array}{c}\text { Loans } \\
\text { (millions of } \\
\text { CFAF) }\end{array}$ & $\begin{array}{c}\text { Deposits } \\
\text { (millions of } \\
\text { CFAF) }\end{array}$ \\
\hline $\begin{array}{c}\text { URCOOPEC } \\
\text { N'Djamena }\end{array}$ & 10 & 32,200 & 1,939 & 2,273 \\
\hline UCEEC Pala & 40 & 33,341 & 515 & 1,159 \\
\hline $\begin{array}{c}\text { ASDEC } \\
\text { Moundou }\end{array}$ & 49 & 9,135 & 149 & 189 \\
\hline $\begin{array}{c}\text { PARCEC-MC } \\
\text { Sarh }\end{array}$ & 25 & 13,335 & 306 & 528 \\
\hline $\begin{array}{c}\text { CDCR/ONDR } \\
\text { Mondou }\end{array}$ & 55 & 8,800 & 0 & 58 \\
\hline $\begin{array}{c}\text { ASSOCEC } \\
\text { N'Djamena }\end{array}$ & 8 & 507 & 35 & 34 \\
\hline Total & 187 & 97,318 & 2,944 & 4,241 \\
\hline
\end{tabular}

Source: Mission of the Commission Bancaire de l'Afrique Centrale for the Evaluation of the Microfinance Credit in Chad (November 2004-February 2005).

\section{Chad has the second-highest number of operating MFIs among CEMAC} countries, according to the COBAC. The microfinance sector is more developed only in Cameroon, where two-thirds of all CEMAC MFIs are located. The sector is still very small in the Central African Republic, Gabon, and Equatorial Guinea.

Table 3. CEMAC: Number of MFIs per Country, 2004

\begin{tabular}{|l|l|l|l|l|l|l|}
\hline Cameroon & CAR & Congo & Gabon & $\begin{array}{l}\text { Equatorial } \\
\text { Guinea 1/ }\end{array}$ & Chad & Total \\
\hline 652 & 36 & 69 & 13 & 2 & 214 & 986 \\
\hline
\end{tabular}

Source: Mission of the Commission Bancaire de l'Afrique Centrale for the Evaluation of the Microfinance Credit in Chad (November 2004-February 2005).

$1 /$ As of 2003.

7. MFIs, which at first operated informally, are now being incorporated into the CEMAC regulatory framework on microfinance adopted in $2002 .{ }^{71}$ This regulatory framework defines the scope of permissible activities for credit cooperatives, essentially ensuring that they limit their size and activities to agreed-upon parameters and operate within a network structure. The main elements of the regulations are as follows: (i) MFIs need to hold a valid license to operate; (ii) MFIs can operate only in the country in which they are registered and must join that country's professional MFI association; and, (iii) COBAC will be responsible for regulating and sanctioning MFIs. In addition, prudential regulations, which are stricter for MFIs than for commercial banks, vary by type of MFI and fall into three categories: category-one MFIs collect deposits and lend exclusively to their members;

\footnotetext{
${ }^{71}$ The framework consist of the CEMAC regulations and 21 prudential norms issued by COBAC. The CEMAC regulation came into force in April 2005, while the COBAC regulations will become effective in April 2007.
} 
category-two MFIs collect deposits and lend to nonmembers; and category-three MFIs lend only to third parties without accepting deposits. In 2004, most MFIs were classified as category one. In compliance with the CEMAC regulations, Chad has set up a professional association for MFIs and a department for microfinance issues within the Ministry of Finance. The MFI licenses issued by this department are in the process of being verified and validated by the COBAC.

8. The government and donors recognize the importance of MFIs in financing the Chadian economy. The National Poverty Reduction Strategy (NPRS) views microfinance as a poverty reduction tool, prompting some banks and donors to back selected MFIs (see Ministry of Plan, Cooperation, and Development, 2002 and 2003).

\section{Saving Mobilization by MFIs}

9. MFIs have successfully mobilized deposits and promoted domestic saving, in part because banking system outreach remains limited. Because banks operate only in a few urban areas, accessing bank accounts is too costly for most people, especially for those living in rural areas. MFIs have been successful in promoting a culture of saving in villages and small towns. In 2004, MFIs offered financial services to twice as many individuals as banks and were present in 20 times as many locations (Table 4). In addition, MFIs have fostered entrepreneurship by financing the establishment of businesses and the creation of cooperatives and partnerships. Also, the flexibility and accessibility of MFIs make it possible to combat usury in the informal sector.

Table 4. Banks and MFIs in Chad, at June 30, 2004

\begin{tabular}{|l|l|l|l|l|l|}
\hline & $\begin{array}{l}\text { Offices or } \\
\text { Branches } \\
\text { (total number) }\end{array}$ & $\begin{array}{l}\text { Deposits } \\
\text { (CFAF } \\
\text { millions) }\end{array}$ & $\begin{array}{l}\text { Loans (CFAF } \\
\text { millions) }\end{array}$ & $\begin{array}{l}\text { Members or } \\
\text { Customers }\end{array}$ & $\begin{array}{l}\text { Towns or } \\
\text { Localities }\end{array}$ \\
\hline Banks & 20 & 102,127 & 112,002 & 59,553 & 5 \\
\hline MFIs & 214 & 4,419 & 3,669 & 98,378 & 94 \\
\hline
\end{tabular}

Source: Mission of the Commission Bancaire de l'Afrique Centrale for the Evaluation of the Microfinance Credit in Chad (November 2004-February 2005).

10. MFIs have been innovative in establishing credit tailored to borrowers' specific circumstances. Lending rates range between 14 and 60 percent per year, with the majority of loans carrying a rate of 24 percent rate (significantly above the 12-18 percent per year offered by commercial banks). Required collateral includes cattle, land, equipment, and personal endorsement. Loans offered by MFIs comprise:

Commercial loans, targeted to members in the business sector, particularly people establishing new enterprises. The terms of these loans vary from 1 to 12 months.

Construction/housing loans, which are becoming increasingly popular in towns. Lowincome individuals who permanently deposit their wages in MFIs can obtain loans for 
housing construction or home improvement. The terms of these loans range from 6 to 24 months.

Agricultural loans. Despite the importance of agriculture, which employs approximately

4.5 million workers, private investment in the sector is still limited, owing to structural underfunding (which has kept the sector from advancing technologically). Bank credit for farming accounts for only 1 percent of the total volume of credit extended annually. By contrast, most MFIs are located in villages, near farmers.

Educational and social loans, offered at the beginning of each school year so members

can buy school supplies and pay school fees. The terms of these loans range from 2 to 6 months.

Social loans, which vary in type, but are mostly emergency loans and are usually granted to help members deal with unforeseen family problems, such as illness or death.

Extenuating circumstances are taken into account in the disbursement of these loans.

11. The bulk of the loans are geared toward income-generating economic activities, including business, investment, and crop credits. Women account for 87 percent of total borrowing.

Table 5. Share of Loans by Activity and Gender of Beneficiary in N'Djamena (Percent)

\begin{tabular}{|l|c|c|c|}
\hline \multirow{2}{*}{ PURPOSE OF LOAN } & \multicolumn{3}{|c|}{ GENDER } \\
\cline { 2 - 4 } & MALE & FEMALE & TOTAL \\
\hline Business & 32.8 & 63.1 & 41.8 \\
\hline Investment & 17.9 & 9.3 & 15.3 \\
\hline Housing/Construction & 28.0 & 14.3 & 23.9 \\
\hline Crop year & 2.7 & 0.7 & 4.7 \\
\hline Social & 5.4 & 3.1 & 12.2 \\
\hline Education & 13.4 & 9.4 & 100.0 \\
\hline TOTAL & 100.0 & 100.0 & (U) \\
\hline
\end{tabular}

Source: Regional Union of Saving and Loan Cooperatives of N'Djamena (URCOOPEC), 2004, Fact Sheet.

\section{Weaknesses and Challenges of Chad's Microfinance Sector}

12. The microfinance sector's expansion has been geographically uneven, and the size of its operations remains only a fraction of the commercial bank sector's. MFIs are unevenly distributed throughout the country, with most located in the central and southern regions, where the bulk of the economic activity takes place. While there are many MFIs, the scale of their deposits ( 4 percent of commercial banks') and credits ( 3 percent of commercial banks') remains small.

\section{In general, the management and financial performance of Chad's MFIs are} weak. Most MFIs have poor management procedures, high administrative costs, and poor internal controls mechanisms. In addition, the quality of staffing is still substandard, given the sector's grassroots nature and lack of trained managers. Indeed, MFIs are often managed by unqualified personnel with limited strategic vision for developing the enterprise. Some 
MFIs face serious cash shortages and are not financially viable. For example, one MFI in N'Djamena faced serious financial problems, after it extended large amounts of credit to civil servants who faced salary arrears. Several MFIs supported by foreign partners rely on subsidies.

14. In addition, rapid MFI growth has made it significantly more difficult to manage and monitor their activities. MFI staff credentials and MFI information management system have not kept pace with the industry's growth. Some managers, accountants, cashiers, and loan officers are overwhelmed by the functional complexity of transactions, especially since these transactions are still handled manually. The scant use of information technology tools makes MFI operations less secure, slows service delivery, and creates important bottlenecks. Delays in the production of a borrower database on borrowers have undermined the networks' ability to monitor grassroots MFI activities.

\section{A number of institutional challenges continue to hamper the development of} Chad's microfinance sector, including (i) the absence of a national microfinance policy and strategy; (ii) poor dissemination of microfinance legislation; (iii) a lack of coordination among ministries responsible for regulating and promoting MFIs (agriculture, finance, and planning and development); (iv) a lengthy process for closing a nonviable MFI; (v) widespread insecurity, which threatens MFI deposits generally; and (vi) a lack of human and technological resources within the microfinance department of the ministry of finance, which monitors MFI operations (see Ministry of Finance, 2003).

\section{E. Conclusions and Recommendations}

\section{The emergence of MFIs in Chad has helped improve the population's access to}

financial services. However, MFI expansion has been geographically uneven, the operations of such institutions remain small, and MFI management and financial performance are weak. In addition, rapid MFI growth has created pressure for improved human resource and information technology systems.

17. Promoting the balanced and sound development of the microfinance sector is essential to implementing Chad's poverty reduction strategy and achieving sustained economic growth. Related measures include (i) training MFI staff and management in bookkeeping, reporting standards, internal controls, and credit decision making, (ii) improving MFI technology systems, (iii) furthering efforts to regulate the microfinance sector, and (iv) strengthening the general judicial environment. 


\section{References}

Commission Bancaire de l'Afrique Centrale (COBAC), 2005, Inventory and assessment of Microfinance Institutions in Chad, Report elaborated by the COBAC evaluation mission from November 2004-February 2005.

Ministry of Finance, 2003, Brief on the status of microfinance in Chad, November.

Mourji, F., 2002, Le financement semi-formel du secteur informel au Maroc: le micro-crédit, une alternative à l'impasse?, Université Hassan II Ain Chock, Casablanca, Maroc.

Regional Union of Saving and Loan Cooperatives of N'djamena, 2004, Fact sheet, Ndjamena, November.

Ministry of Plan, Cooperation, and Development, 2002, National policy paper on microfinance in the Republic of Chad, N'Djamena, November.

Ministry of Plan, Cooperation, and Development, 2003, National Poverty Reduction Strategy Paper, Ndjamena, June. 


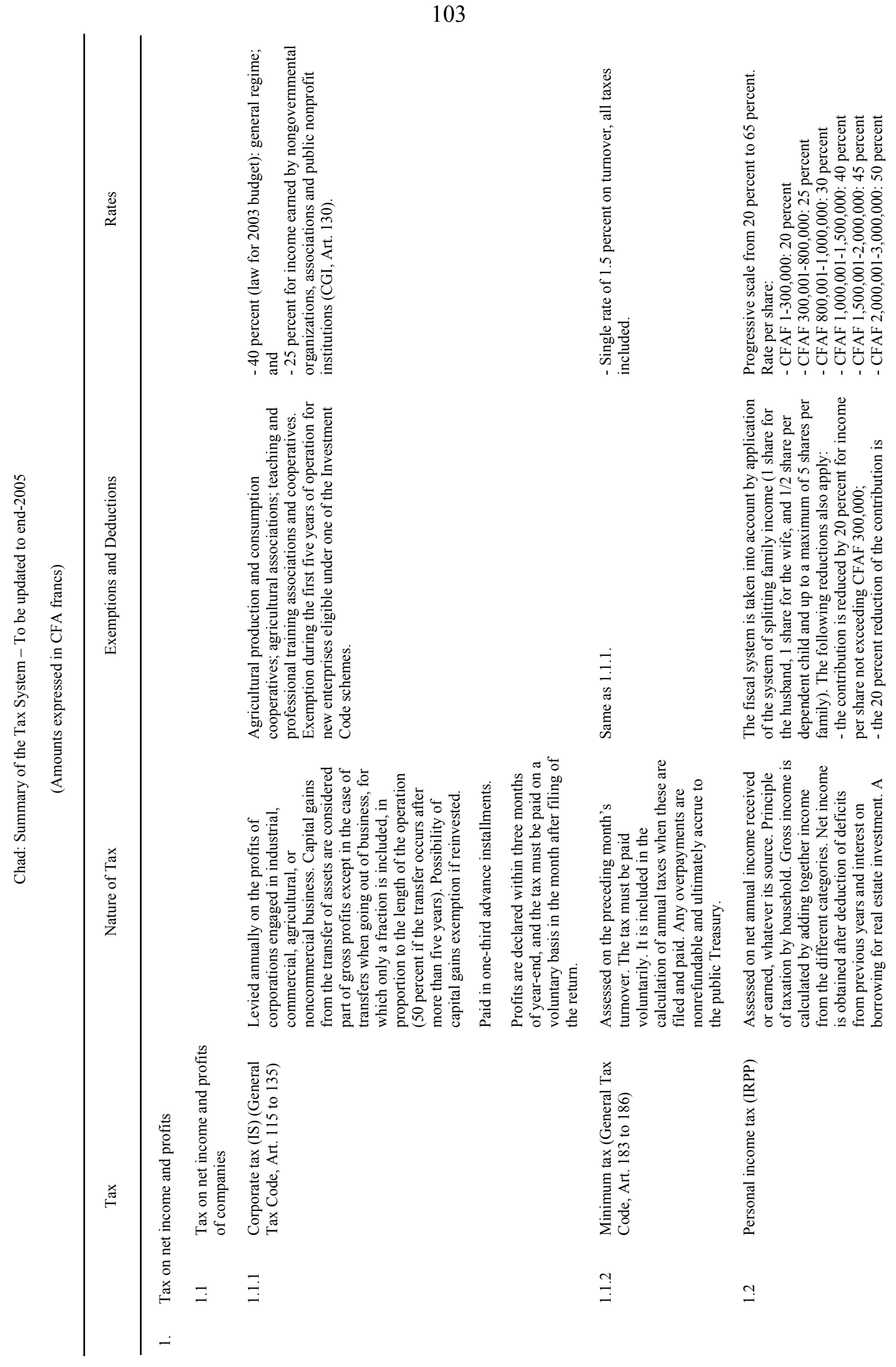




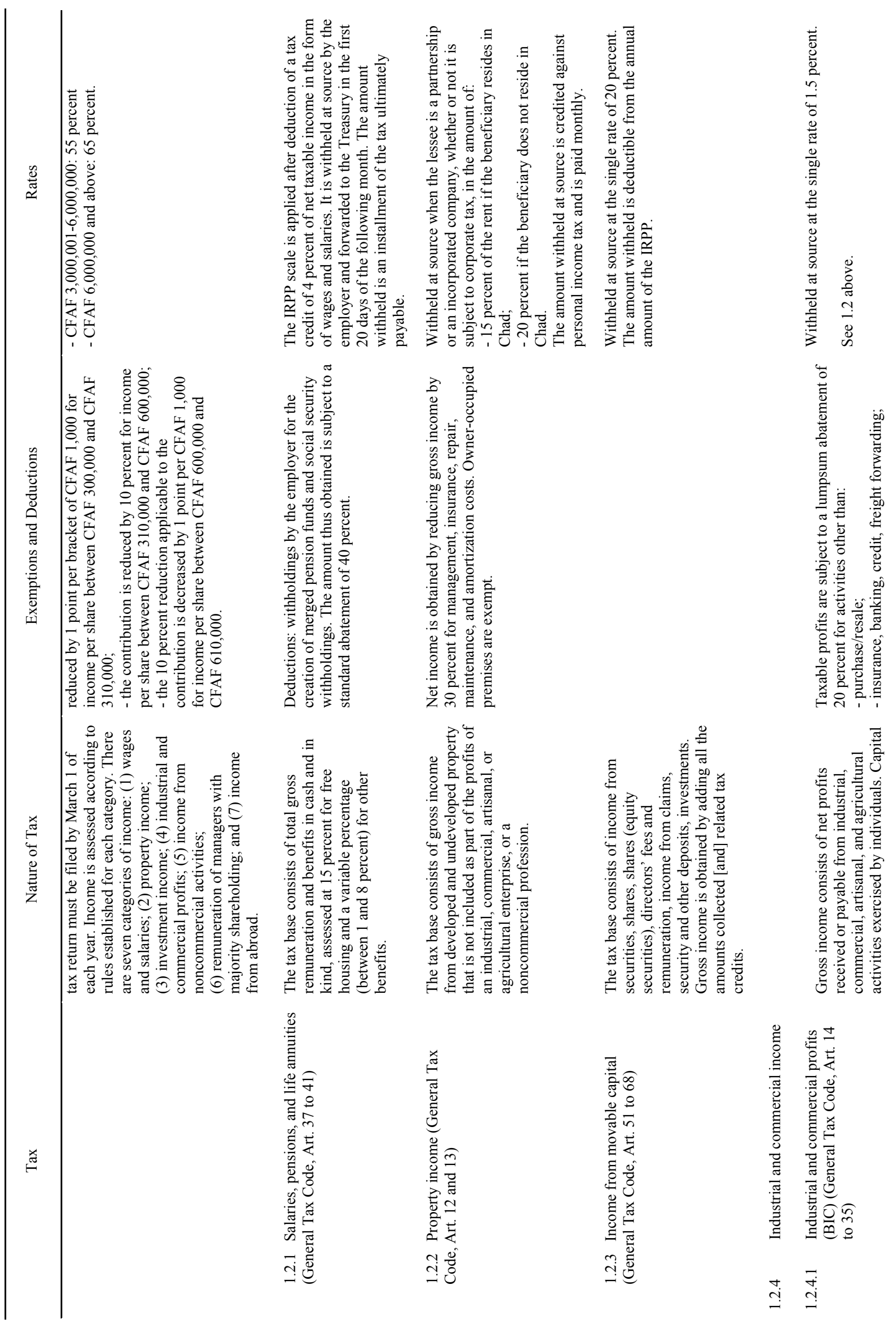




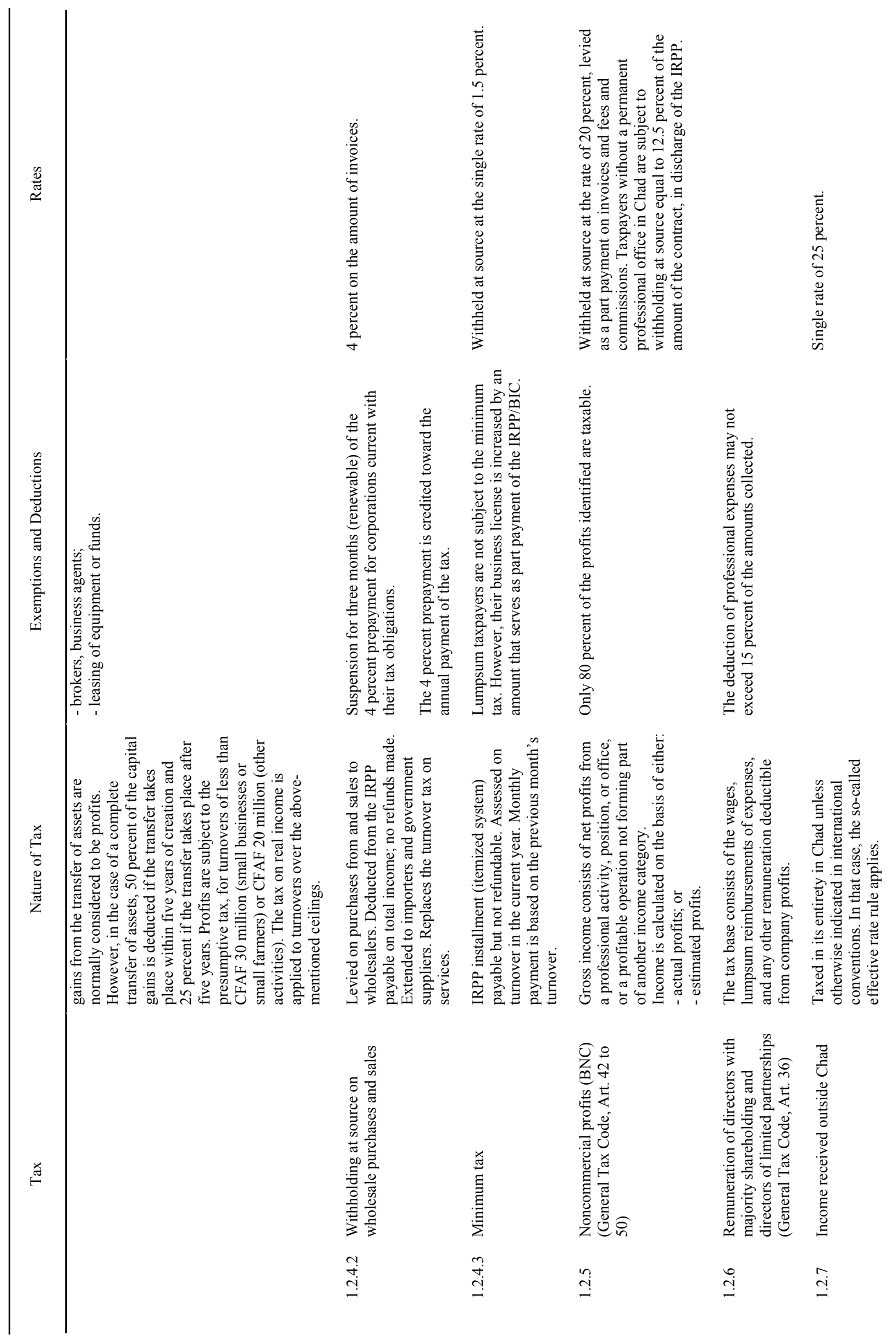




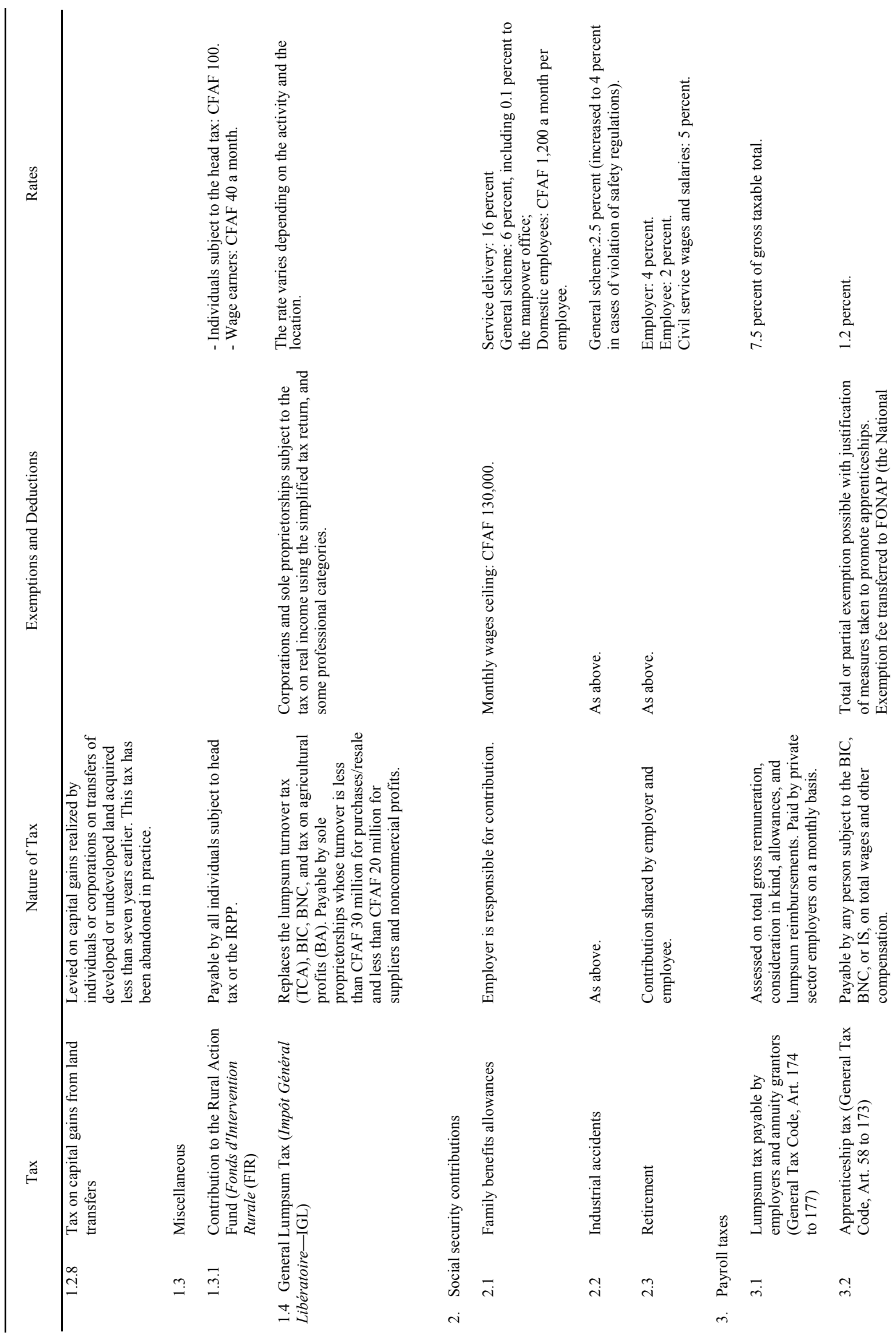




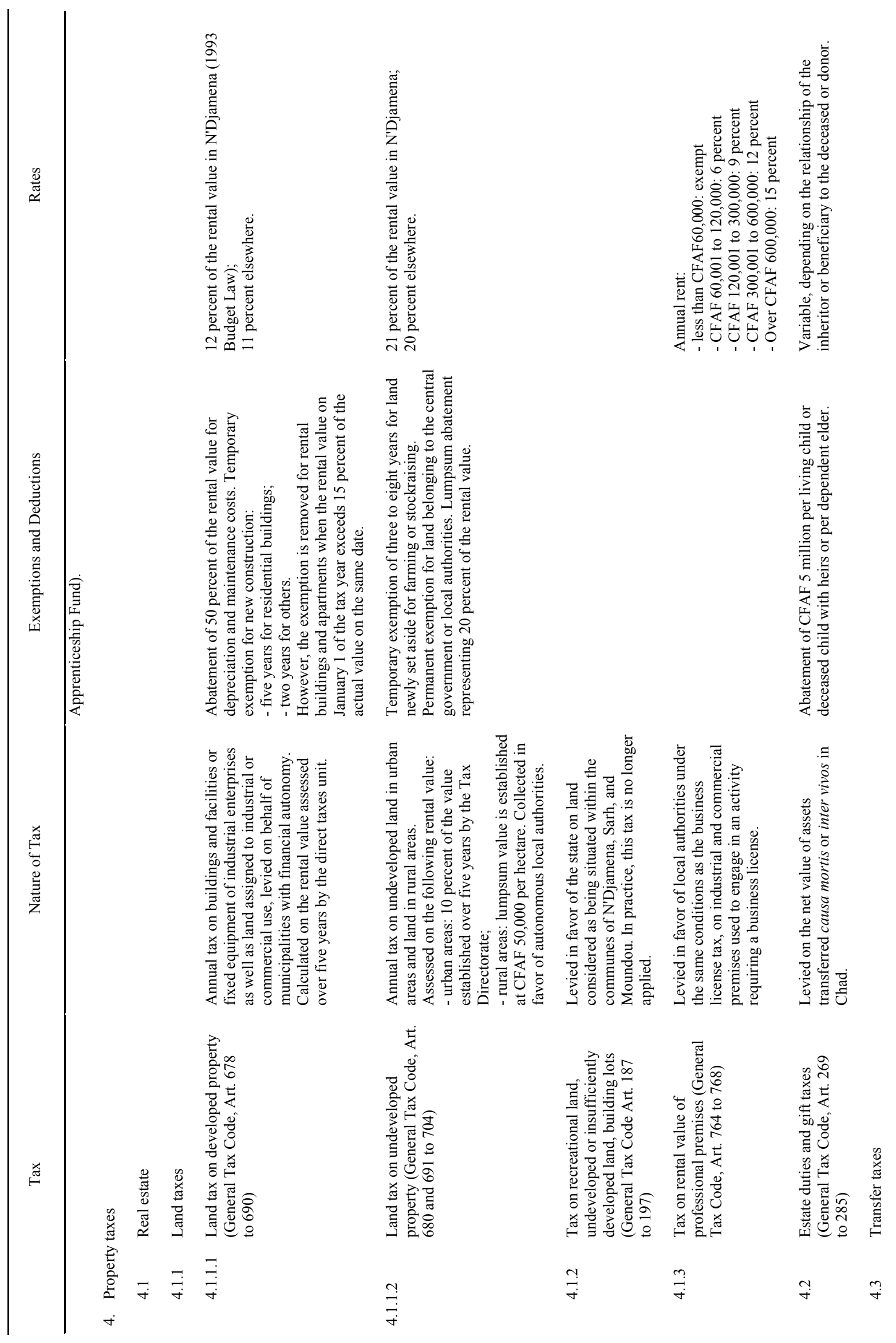


108

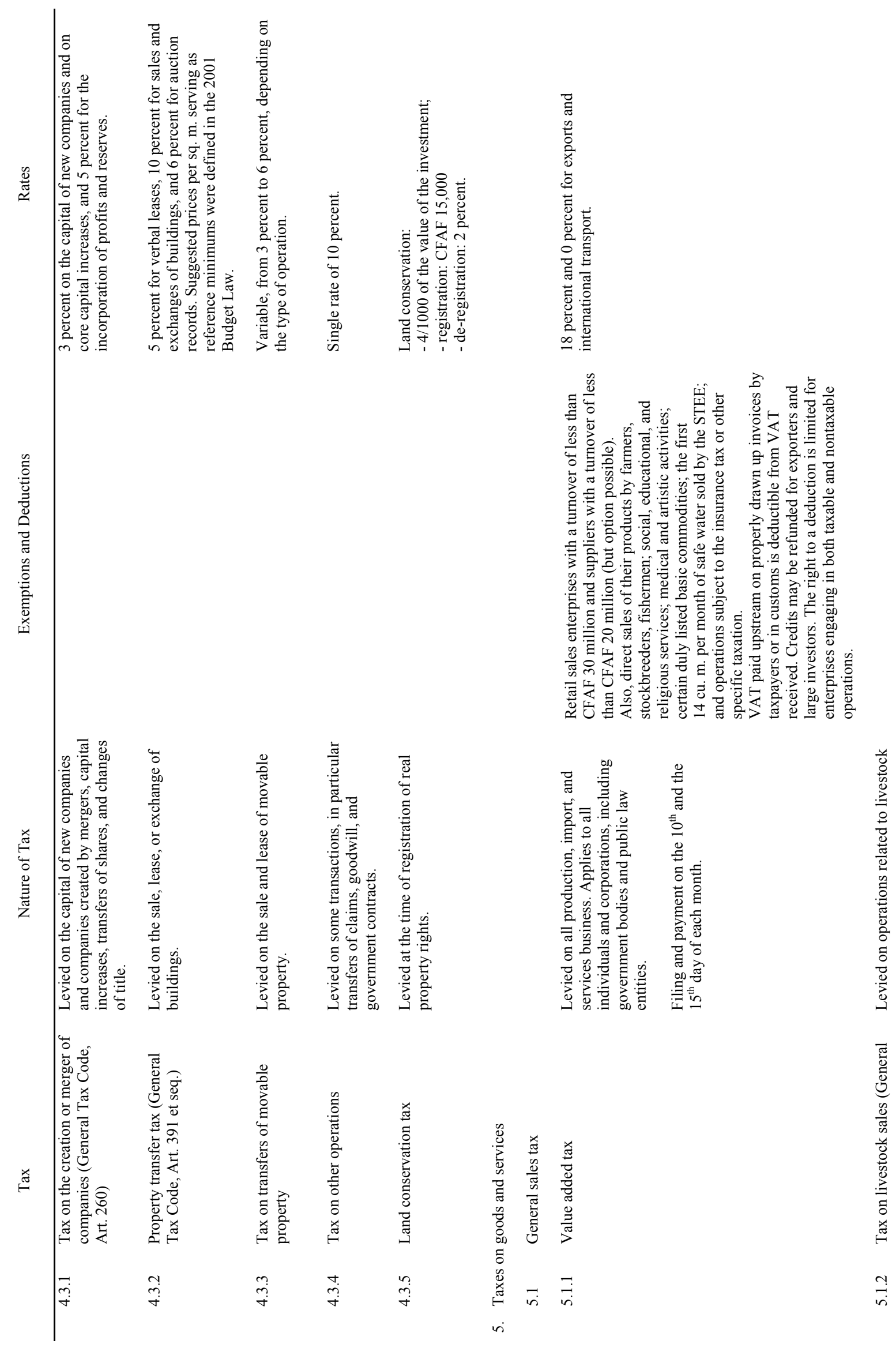




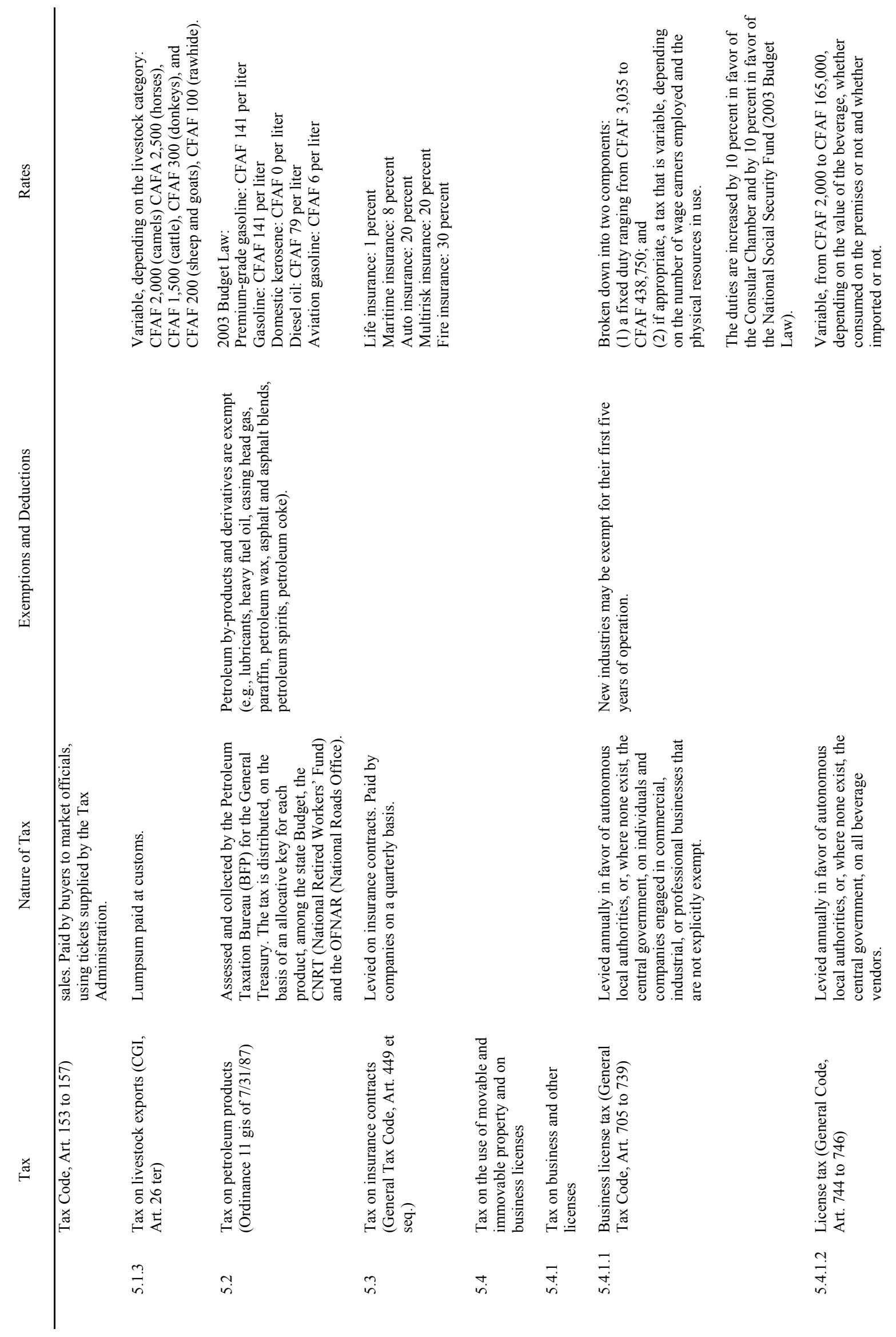




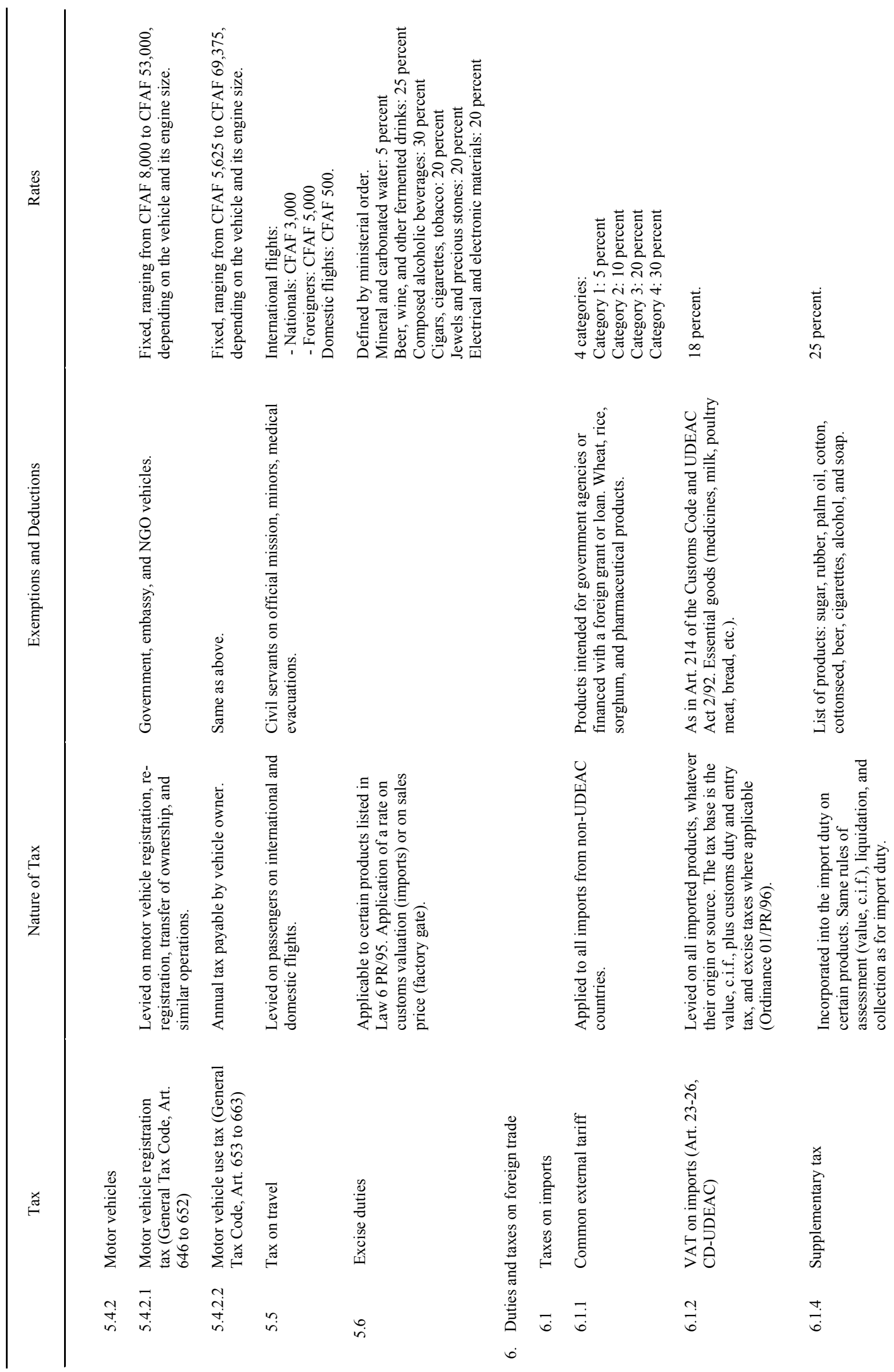




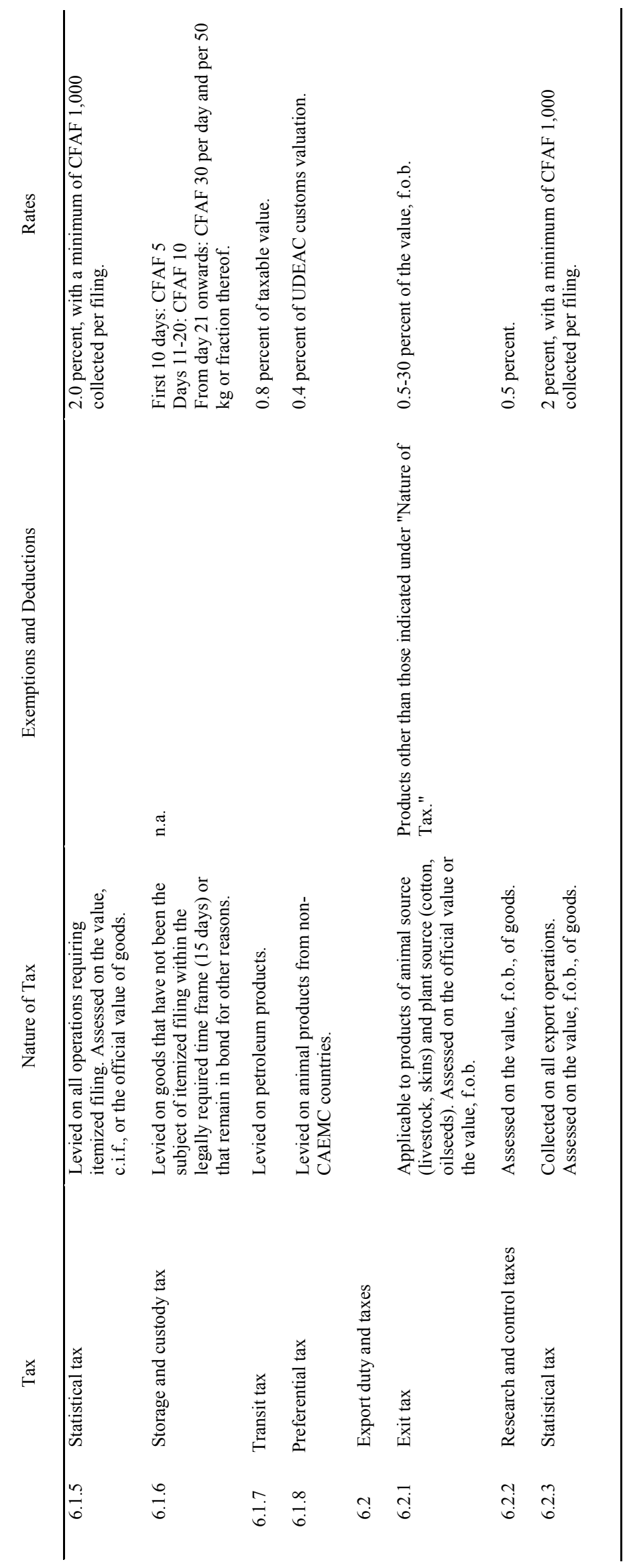


Chad: Basic Data

\begin{tabular}{|c|c|c|c|c|c|c|c|c|}
\hline & 1998 & 1999 & 2000 & 2001 & 2002 & 2003 & 2004 & 2005 \\
\hline & \multicolumn{8}{|c|}{ (In billions of CFA francs) } \\
\hline \multicolumn{9}{|l|}{ Gross domestic product } \\
\hline At current prices & $1,029.3$ & 944.9 & 986.1 & $1,253.0$ & $1,385.3$ & $1,582.4$ & $2,332.2$ & $3,111.2$ \\
\hline At constant prices $(1995=100)$ & 832.8 & 827.1 & 819.8 & 915.4 & 993.1 & $1,139.3$ & $1,495.6$ & $1,677.9$ \\
\hline \multicolumn{9}{|l|}{ Government finance } \\
\hline Total revenue and grants & 127.1 & 122.3 & 135.4 & 155.5 & 197.4 & 247.4 & 267.4 & 393.8 \\
\hline Of which: grants & 50.9 & 44.6 & 55.2 & 63.8 & 84.9 & 122.7 & 69.4 & 104.2 \\
\hline Expenditure and net lending & 153.3 & 178.8 & 203.2 & 220.3 & 280.3 & 348.0 & 336.8 & 404.9 \\
\hline Current & 75.0 & 87.9 & 99.9 & 109.8 & 140.0 & 149.4 & 154.7 & 187.3 \\
\hline Capital and net lending & 78.4 & 90.9 & 103.3 & 110.5 & 140.3 & 198.6 & 182.1 & 217.7 \\
\hline Overall balance (commitment basis, including gran & -26.2 & -56.5 & -67.8 & -64.9 & -83.0 & -100.7 & -69.4 & -11.1 \\
\hline \multicolumn{9}{|l|}{ Money and credit (end of period) } \\
\hline Net foreign assets & 42.7 & 37.4 & 35.9 & 27.8 & 81.3 & 50.3 & 61.3 & 86.6 \\
\hline Medium- and long-term foreign liabilities & 0.0 & -2.0 & -2.3 & -1.9 & -2.4 & -4.3 & -5.5 & -7.7 \\
\hline Net domestic assets & 62.8 & 68.9 & 89.7 & 125.6 & 109.3 & 136.3 & 132.4 & 252.9 \\
\hline Credit to the public sector (net) & 36.2 & 48.2 & 61.9 & 77.4 & 76.1 & 87.2 & 83.4 & 85.9 \\
\hline Credit to the economy & 54.3 & 59.1 & 65.9 & 79.8 & 79.1 & 98.1 & 92.9 & 129.6 \\
\hline Other items (net) & -27.7 & -38.4 & -38.0 & -31.5 & -46.0 & -49.1 & -43.8 & 37.4 \\
\hline Broad money & 105.5 & 104.3 & 123.3 & 147.6 & 188.2 & 182.3 & 188.3 & 480.9 \\
\hline & \multicolumn{8}{|c|}{ (In millions, midyear) } \\
\hline \multirow[t]{2}{*}{ Population } & 7.1 & 7.3 & 7.5 & 7.7 & 7.9 & 8.6 & 8.8 & 9.0 \\
\hline & \multicolumn{8}{|c|}{ (In billions of CFA francs) } \\
\hline \multicolumn{9}{|l|}{ Balance of payments } \\
\hline Exports, f.o.b. & 154.3 & 140.2 & 130.2 & 138.4 & 128.9 & 350.4 & 1142.1 & 1639.2 \\
\hline Imports, f.o.b & -165.8 & -162.3 & -170.4 & -377.8 & -1107.3 & -453.2 & -462.3 & -428.1 \\
\hline Trade balance (including oil sector) & -11.5 & -22.1 & -40.2 & -239.4 & -978.4 & -102.8 & 679.8 & 1211.1 \\
\hline Services (net, including oil sector) & -102.5 & -109.0 & -135.2 & -199.0 & -420.4 & -439.8 & -674.0 & -736.2 \\
\hline Factor income (net) & -0.4 & -1.0 & -12.4 & -16.5 & -41.5 & -265.3 & -231.5 & -543.2 \\
\hline Private transfers (net) & 14.0 & 5.5 & 4.6 & 14.4 & 22.9 & 14.6 & 41.9 & 32.5 \\
\hline Current account balance $1 /$ & -100.4 & -126.6 & -183.2 & -440.5 & -1417.4 & -793.3 & -183.8 & -35.8 \\
\hline Official transfers & 29.0 & 20.1 & 31.4 & 18.4 & 26.9 & 43.0 & 72.9 & 62.3 \\
\hline Current account balance $2 /$ & -71.4 & -106.5 & -151.8 & -422.1 & -1390.5 & -750.3 & -110.9 & 26.5 \\
\hline Medium- and long-term capital (net) & 64.1 & 81.1 & 155.4 & 491.3 & 752.7 & 540.8 & 390.6 & 420.6 \\
\hline Short-term capital (net), and errors and omissions & 6.4 & 10.3 & -2.4 & -77.2 & 674.2 & 182.8 & -267.2 & -436.7 \\
\hline Overall balance & -0.9 & -15.2 & 1.1 & -8.0 & 36.3 & -26.7 & 12.5 & 10.5 \\
\hline \multicolumn{9}{|l|}{ External public debt } \\
\hline Stock of debt ( in billions of CFA francs) $3 /$ & 558.4 & 619.8 & 721.7 & 721.9 & 732.8 & 731.3 & 756.6 & 880.7 \\
\hline \multirow[t]{2}{*}{ Debt service $4 /$} & 15.1 & 38.1 & 26.8 & 27.6 & 15.2 & 4.4 & 1.5 & 0.2 \\
\hline & \multicolumn{8}{|c|}{ (CFA francs per U.S. dollar) } \\
\hline Exchange rate (annual average) & 590 & 615 & 710 & 732 & 695 & 580 & 528 & 531 \\
\hline
\end{tabular}

Sources: Chadian authorities; and IMF staff estimates.

1/ Excludes official transfers.

2/ Includes official transfers.

3/ After stock-of-debt operation.

4/ In percent of exports of goods and nonfactor services. 
Chad: Basic Data (concluded)

\begin{tabular}{lrl}
\hline & Level & (year) \\
\hline Social and demographic indicators & & \\
Population (midyear; in millions) & 8.8 & 2004 \\
Population growth (annual percentage change) & 2.5 & 2004 \\
GNP per capita (U.S. dollars) & 452 & 2004 \\
Life expectancy at birth (years) & 44 & 2004 \\
Infant mortality rate (per thousand) & & 2004 \\
$\quad$ Under five years infant mortality rate (per thousand) & 200 & 2004 \\
Population per physician & 25,664 & 2004 \\
Adult illiteracy rate (in percent) & & 2004 \\
$\quad$ Male & 59 & 2003 \\
$\quad$ Female & 87 & 2004 \\
Ret primary enrollment & 57 & \\
\hline
\end{tabular}

Sources: Chadian authorities; World Bank, World Development Indicators Online, 2006; and IMF staff estimates. 
Table 1. Chad: Gross Domestic Product by Sector of Origin,1998-2005

(At current prices)

\begin{tabular}{|c|c|c|c|c|c|c|c|c|}
\hline & 1998 & 1999 & 2000 & 2001 & 2002 & 2003 & 2004 & 2005 \\
\hline & \multicolumn{7}{|c|}{ (In billions of CFA francs) } & \\
\hline Primary sector & 401.5 & 359.7 & 401.4 & 504.9 & 525.1 & 691.2 & $1,459.1$ & $1,997.1$ \\
\hline Agriculture & 250.8 & 190.2 & 193.0 & 246.8 & 244.2 & 218.7 & 235.9 & 333.3 \\
\hline Livestock & 120.7 & 138.2 & 176.0 & 222.3 & 232.3 & 239.5 & 246.9 & 257.3 \\
\hline Fishing and mining & 30.0 & 31.3 & 32.5 & 35.8 & 48.6 & 55.3 & 49.5 & 58.3 \\
\hline Oil Sector 1/ & 0.0 & 0.0 & 0.0 & 0.0 & 0.0 & 177.7 & 926.8 & $1,348.2$ \\
\hline Secondary sector & 132.5 & 115.4 & 107.6 & 163.9 & 197.5 & 194.7 & 182.6 & 220.7 \\
\hline Manufacturing and handicrafts & 110.9 & 92.4 & 84.7 & 115.4 & 125.5 & 122.0 & 117.5 & 143.3 \\
\hline Water and electricity & 5.7 & 6.2 & 6.0 & 6.7 & 7.9 & 7.0 & 7.1 & 9.2 \\
\hline Construction and public works & 14.2 & 15.3 & 14.9 & 18.2 & 20.7 & 24.3 & 27.8 & 31.4 \\
\hline Oil sector $2 /$ & 1.7 & 1.5 & 2.1 & 23.7 & 43.5 & 41.4 & 30.2 & 35.7 \\
\hline Tertiary sector & 449.7 & 429.9 & 439.6 & 538.8 & 608.6 & 642.6 & 633.7 & 840.0 \\
\hline Commerce and transport & 259.0 & 232.6 & 233.6 & 292.9 & 343.0 & 349.0 & 360.5 & 423.9 \\
\hline Public administration & 98.4 & 110.6 & 117.8 & 140.0 & 151.9 & 171.6 & 184.3 & 208.3 \\
\hline Services & 90.3 & 84.7 & 83.7 & 102.9 & 108.7 & 122.4 & 46.9 & 257.8 \\
\hline Sum of value added & 983.6 & 905.0 & 948.6 & $1,207.6$ & $1,331.2$ & $1,528.5$ & $2,275.3$ & $3,057.8$ \\
\hline Duties and taxes on imports & 45.7 & 39.9 & 37.5 & 45.4 & 54.1 & 53.9 & 56.9 & 53.4 \\
\hline GDP at market prices & $1,029.3$ & 944.9 & 986.1 & $1,253.0$ & $1,385.3$ & $1,582.4$ & $2,332.2$ & $3,111.2$ \\
\hline \multirow[t]{2}{*}{ Non-oil GDP at market prices } & $1,027.7$ & 943.4 & 984.0 & $1,229.4$ & $1,341.9$ & $1,363.3$ & $1,375.2$ & $1,727.3$ \\
\hline & \multicolumn{8}{|c|}{ (In percent of total) } \\
\hline Primary sector & 39.0 & 38.1 & 40.7 & 40.3 & 37.9 & 43.7 & 62.6 & 64.2 \\
\hline Agriculture & 24.4 & 20.1 & 19.6 & 19.7 & 17.6 & 13.8 & 10.1 & 10.7 \\
\hline Livestock & 11.7 & 14.6 & 17.8 & 17.7 & 16.8 & 15.1 & 10.6 & 8.3 \\
\hline Fishing and mining & 2.9 & 3.3 & 3.3 & 2.9 & 3.5 & 3.5 & 2.1 & 1.9 \\
\hline Secondary sector & 12.9 & 12.2 & 10.9 & 13.1 & 14.3 & 12.3 & 7.8 & 7.1 \\
\hline Manufacturing and handicrafts & 10.8 & 9.8 & 8.6 & 9.2 & 9.1 & 7.7 & 5.0 & 4.6 \\
\hline Water and electricity & 0.6 & 0.7 & 0.6 & 0.5 & 0.6 & 0.4 & 0.3 & 0.3 \\
\hline Construction and public works & 1.4 & 1.6 & 1.5 & 1.4 & 1.5 & 1.5 & 1.2 & 1.0 \\
\hline Tertiary sector & 43.7 & 45.5 & 44.6 & 43.0 & 43.9 & 40.6 & 27.2 & 27.0 \\
\hline Commerce and transport & 25.2 & 24.6 & 23.7 & 23.4 & 24.8 & 22.1 & 15.5 & 13.6 \\
\hline Public administration & 9.6 & 11.7 & 11.9 & 11.2 & 11.0 & 10.8 & 7.9 & 6.7 \\
\hline Services & 8.8 & 9.0 & 8.5 & 8.2 & 7.8 & 7.7 & 2.0 & 8.3 \\
\hline Sum of value added & 95.6 & 95.8 & 96.2 & 96.4 & 96.1 & 96.6 & 97.6 & 98.3 \\
\hline Duties and taxes on imports & 4.4 & 4.2 & 3.8 & 3.6 & 3.9 & 3.4 & 2.4 & 1.7 \\
\hline GDP at market prices & 100.0 & 100.0 & 100.0 & 100.0 & 100.0 & 100.0 & 100.0 & 100.0 \\
\hline Non-oil GDP at market prices & 99.8 & 99.8 & 99.8 & 98.1 & 96.9 & 86.2 & 59.0 & 55.5 \\
\hline
\end{tabular}

Sources: Chadian authorities; and IMF staff estimates.

$1 /$ Includes oil production and transportation.

2/ Includes investment of the oil sector related to the construction of the pipeline and explorations works. 
Table 2. Chad: Gross Domestic Product by Sector of Origin, 1998-2005

(At constant 1995 prices)

\begin{tabular}{|c|c|c|c|c|c|c|c|c|}
\hline & 1998 & 1999 & 2000 & 2001 & 2002 & 2003 & 2004 & 2005 \\
\hline \multicolumn{9}{|c|}{ (In billions of CFA francs) } \\
\hline Primary sector & 311.8 & 301.4 & 293.8 & 323.7 & 321.8 & 427.2 & 778.2 & 818.5 \\
\hline Agriculture & 171.1 & 156.7 & 144.6 & 169.7 & 163.2 & 174.6 & 151.2 & 187.6 \\
\hline Livestock & 116.2 & 119.3 & 122.6 & 125.9 & 129.4 & 132.9 & 136.6 & 140.4 \\
\hline Fishing and mining & 24.5 & 25.4 & 26.6 & 28.1 & 29.2 & 30.9 & 30.9 & 34.2 \\
\hline Oil sector $1 /$ & 0.0 & 0.0 & 0.0 & 0.0 & 0.0 & 88.8 & 459.5 & 456.3 \\
\hline Secondary sector & 118.6 & 111.7 & 109.9 & 125.5 & 155.8 & 159.3 & 147.1 & 172.8 \\
\hline Manufacturing and handicrafts & 99.9 & 91.1 & 89.5 & 85.8 & 97.0 & 97.9 & 91.9 & 107.2 \\
\hline Water and electricity & 5.4 & 6.0 & 5.7 & 6.3 & 7.3 & 6.3 & 6.2 & 8.1 \\
\hline Construction and public works & 11.9 & 13.3 & 12.9 & 14.5 & 16.6 & 20.4 & 23.5 & 26.9 \\
\hline Oil sector $2 /$ & 1.4 & 1.3 & 1.8 & 18.9 & 34.9 & 34.7 & 25.5 & 30.6 \\
\hline Tertiary sector & 366.0 & 381.6 & 384.4 & 430.1 & 472.4 & 508.0 & 521.5 & 632.6 \\
\hline Commerce and transport & 209.8 & 210.0 & 211.1 & 238.9 & 268.1 & 274.7 & 292.1 & 314.2 \\
\hline Public administration & 76.0 & 91.1 & 94.3 & 101.9 & 108.9 & 128.6 & 143.8 & 160.6 \\
\hline Services & 80.2 & 80.5 & 79.0 & 89.3 & 95.4 & 104.7 & 85.6 & 157.8 \\
\hline Sum of value added & 796.4 & 794.7 & 788.0 & 879.3 & 950.0 & 1094.5 & 1446.8 & 1623.9 \\
\hline Duties and taxes on imports & 36.4 & 32.4 & 31.8 & 36.1 & 43.1 & 44.8 & 48.8 & 54.0 \\
\hline GDP at market prices & 832.8 & 827.1 & 819.8 & 915.4 & 993.1 & 1139.3 & 1495.6 & 1677.9 \\
\hline \multirow[t]{2}{*}{ Non-oil GDP at markets prices } & 831.4 & 825.8 & 818.0 & 896.5 & 958.2 & 1015.8 & 1010.6 & 1191.0 \\
\hline & \multicolumn{8}{|c|}{ (Annual changes in percent) } \\
\hline Primary sector & 9.3 & -3.3 & -2.5 & 10.2 & -0.6 & 32.8 & 82.2 & 5.2 \\
\hline Agriculture & 14.8 & -8.4 & -7.7 & 17.4 & -3.8 & 7.0 & -13.4 & 24.1 \\
\hline Livestock & 3.8 & 2.7 & 2.8 & 2.7 & 2.8 & 2.7 & 2.8 & 2.8 \\
\hline Fishing and mining & 1.7 & 3.7 & 4.7 & 5.6 & 3.9 & 5.8 & 0.0 & 10.7 \\
\hline Secondary sector & 10.5 & -5.8 & -1.7 & 14.2 & 24.1 & 2.2 & -7.7 & 17.5 \\
\hline Manufacturing and handicrafts & 11.5 & -8.8 & -1.8 & -4.1 & 13.1 & 0.9 & -6.2 & 16.7 \\
\hline Water and electricity & 2.6 & 11.1 & -5.0 & 10.5 & 15.9 & -13.7 & -1.3 & 30.3 \\
\hline Construction and public works & 9.1 & 11.9 & -3.4 & 12.8 & 14.5 & 22.9 & 15.2 & 14.5 \\
\hline Oil sector & -12.5 & -7.1 & 38.5 & 950.0 & 84.7 & -0.6 & -26.5 & 20.0 \\
\hline Tertiary sector & 3.0 & 4.3 & 0.7 & 11.9 & 9.8 & 7.5 & 2.7 & 21.3 \\
\hline Commerce and transport & 5.5 & 0.1 & 0.5 & 13.2 & 12.2 & 2.5 & 6.3 & 7.6 \\
\hline Public administration & -3.8 & 19.9 & 3.5 & 8.1 & 6.9 & 18.1 & 11.8 & 11.7 \\
\hline Services & 3.8 & 0.4 & -1.9 & 13.1 & 6.9 & 9.8 & -18.3 & 84.3 \\
\hline Sum of value added & 6.5 & -0.2 & -0.8 & 11.6 & 8.0 & 15.2 & 32.2 & 12.2 \\
\hline Duties and taxes on imports & 17.8 & -11.0 & -1.9 & 13.5 & 19.4 & 3.9 & 8.9 & 10.7 \\
\hline GDP at market prices & 7.0 & -0.7 & -0.9 & 11.7 & 8.5 & 14.7 & 31.3 & 12.2 \\
\hline Non-oil GDP at market prices & 7.0 & -0.7 & -0.9 & 9.6 & 6.9 & 6.0 & -0.5 & 17.9 \\
\hline
\end{tabular}

Sources: Chadian authorities; and IMF staff estimates.

$1 /$ Includes oil production and transportation.

$2 /$ Includes investment of the oil sector related to the construction of the pipeline and explorations works. 
Table 3. Chad: Supply and Use of Resources at Current Prices, 1998-2005

\begin{tabular}{|c|c|c|c|c|c|c|c|c|}
\hline \multicolumn{9}{|c|}{ (In billions of CFA francs) } \\
\hline & 1998 & 1999 & 2000 & 2001 & 2002 & 2003 & 2004 & 2005 \\
\hline Supply of resources & 1,348 & 1,249 & 1,328 & 1,811 & 2,696 & 2,237 & 3,049 & 3,765 \\
\hline Gross domestic product & 1,028 & 945 & 986 & 1,253 & 1,385 & 1,582 & 2,332 & 3,110 \\
\hline Non-oil sector & 1,026 & 943 & 984 & 1,229 & 1,342 & 1,363 & 1,375 & 1,676 \\
\hline Imports of goods and services & 320 & 304 & 342 & 558 & 1,311 & 654 & 717 & 654 \\
\hline Non-oil sector & 300 & 253 & 282 & 324 & 401 & 445 & 609 & 533 \\
\hline Goods & 160 & 112 & 111 & 144 & 197 & 244 & 354 & 315 \\
\hline Services & 140 & 142 & 172 & 180 & 204 & 201 & 255 & 218 \\
\hline Oil sector & 20 & 51 & 60 & 234 & 910 & 209 & 108 & 122 \\
\hline \multicolumn{9}{|l|}{ Use of resources } \\
\hline \multicolumn{9}{|l|}{ Gross domestic expenditure } \\
\hline Consumption & 986 & 1,012 & 1,008 & 1,281 & 1,951 & 1,296 & 1,760 & 2,008 \\
\hline Central government & 57 & 65 & 76 & 94 & 107 & 121 & 114 & 140 \\
\hline Private Sector & 929 & 947 & 932 & 1,187 & 1,844 & 1,175 & 1,646 & 1,869 \\
\hline Gross capital formation & 174 & 129 & 230 & 504 & 833 & 829 & 566 & 627 \\
\hline Gross fixed capital formation & 145 & 160 & 207 & 458 & 827 & 773 & 530 & 591 \\
\hline Central government & 78 & 91 & 103 & 111 & 140 & 199 & 182 & 218 \\
\hline Private sector & 67 & 69 & 103 & 348 & 687 & 574 & 348 & 373 \\
\hline Non-oil sector & 16 & 53 & 49 & 60 & 80 & 75 & 84 & 102 \\
\hline Oil sector & 51 & 17 & 54 & 288 & 607 & 499 & 264 & 271 \\
\hline Changes in inventories & 29 & -31 & 23 & 46 & 6 & 56 & 36 & 36 \\
\hline Exports of goods and services & 188 & 173 & 167 & 184 & 176 & 392 & 1,190 & 1,706 \\
\hline Goods & 152 & 140 & 130 & 138 & 129 & 350 & 1,142 & 1,639 \\
\hline of which oil exports & 0 & 0 & 0 & 0 & 0 & 137 & 936 & 1,415 \\
\hline Services & 36 & 33 & 36 & 45 & 47 & 41 & 48 & 66 \\
\hline \multicolumn{9}{|l|}{ Memorandum items: } \\
\hline Gross domestic savings & 42 & -67 & -22 & -28 & -565 & 286 & 572 & 1,102 \\
\hline Resource gap & -132 & -131 & -175 & -374 & $-1,135$ & -262 & 473 & 1,051 \\
\hline Private transfers & 14 & 6 & 5 & 14 & 23 & 15 & 42 & 33 \\
\hline Official Transfers (current) & 29 & 20 & 31 & 18 & 27 & 43 & 73 & 62 \\
\hline Factor income (net) & -9 & -1 & -12 & -17 & -42 & -265 & -232 & -543 \\
\hline Gross national savings & 76 & -43 & 2 & -12 & -557 & 79 & 455 & 653 \\
\hline
\end{tabular}

Sources: Chadian authorities; and IMF staff estimates. 
Table 4. Chad: Supply and Use of Resources at Current Prices, 1995-2005

(In percent of GDP)

\begin{tabular}{|c|c|c|c|c|c|c|c|c|}
\hline & 1998 & 1999 & 2000 & 2001 & 2002 & 2003 & 2004 & 2005 \\
\hline Supply of resources & 131.1 & 132.2 & 134.7 & 144.5 & 194.6 & 141.3 & 130.7 & 121.0 \\
\hline Gross domestic product & 100.0 & 100.0 & 100.0 & 100.0 & 100.0 & 100.0 & 100.0 & 100.0 \\
\hline Imports of goods and servic & 31.1 & 32.2 & 34.7 & 44.5 & 94.6 & 41.3 & 30.7 & 21.0 \\
\hline Goods & 15.6 & 11.8 & 11.2 & 11.5 & 14.2 & 15.4 & 15.2 & 10.1 \\
\hline Services & 13.6 & 15.0 & 17.4 & 14.4 & 14.7 & 12.7 & 10.9 & 7.0 \\
\hline \multicolumn{9}{|l|}{ Use of resources } \\
\hline \multicolumn{9}{|l|}{ Gross domestic expenditure } \\
\hline Consumption & 95.9 & 107.1 & 102.2 & 102.2 & 140.8 & 81.9 & 75.5 & 64.6 \\
\hline Central government & 5.5 & 6.9 & 7.7 & 7.5 & 7.7 & 7.6 & 4.9 & 4.5 \\
\hline Private sector & 90.4 & 100.2 & 94.5 & 94.7 & 133.1 & 74.3 & 70.6 & 60.1 \\
\hline Gross capital formation & 16.9 & 13.7 & 23.3 & 40.3 & 60.2 & 52.4 & 24.3 & 20.2 \\
\hline Gross fixed capital fc & 14.1 & 17.0 & 20.9 & 36.6 & 59.7 & 48.9 & 22.7 & 19.0 \\
\hline Central governmeı & 7.6 & 9.6 & 10.5 & 8.8 & 10.1 & 12.5 & 7.8 & 7.0 \\
\hline Private sector & 6.5 & 7.4 & 10.5 & 27.8 & 49.6 & 36.3 & 14.9 & 12.0 \\
\hline Changes in inventories & 2.8 & -3.3 & 2.3 & 3.7 & 0.4 & 3.5 & 1.5 & 1.2 \\
\hline Exports of goods and serv & 18.3 & 18.3 & 16.9 & 14.7 & 12.7 & 24.8 & 51.0 & 54.8 \\
\hline Goods & 14.8 & 14.8 & 13.2 & 11.0 & 9.3 & 22.1 & 49.0 & 52.7 \\
\hline Services & 3.5 & 3.5 & 3.7 & 3.6 & 3.4 & 2.6 & 2.0 & 2.1 \\
\hline \multicolumn{9}{|l|}{ Memorandum items: } \\
\hline Gross domestic savings & 4.1 & -7.1 & -2.2 & -2.2 & -40.8 & 18.1 & 24.5 & 35.4 \\
\hline Resource gap & -12.8 & -13.9 & -17.8 & -29.9 & -81.9 & -16.6 & 20.3 & 33.8 \\
\hline Private transfers & 1.4 & 0.6 & 0.5 & 1.1 & 1.7 & 0.9 & 1.8 & 1.0 \\
\hline Official Transfers (current) & 2.8 & 2.1 & 3.2 & 1.5 & 1.9 & 2.7 & 3.1 & 2.0 \\
\hline Factor income & -0.9 & -0.1 & -1.3 & -1.3 & -3.0 & -16.8 & -9.9 & -17.5 \\
\hline Gross national savings & 7.4 & -4.5 & 0.2 & -0.9 & -40.2 & 5.0 & 19.5 & 21.0 \\
\hline
\end{tabular}

Sources: Chadian authorities; and IMF staff estimates. 
118

Table 5. Chad: Consumer Price Index, 1997-June 2006

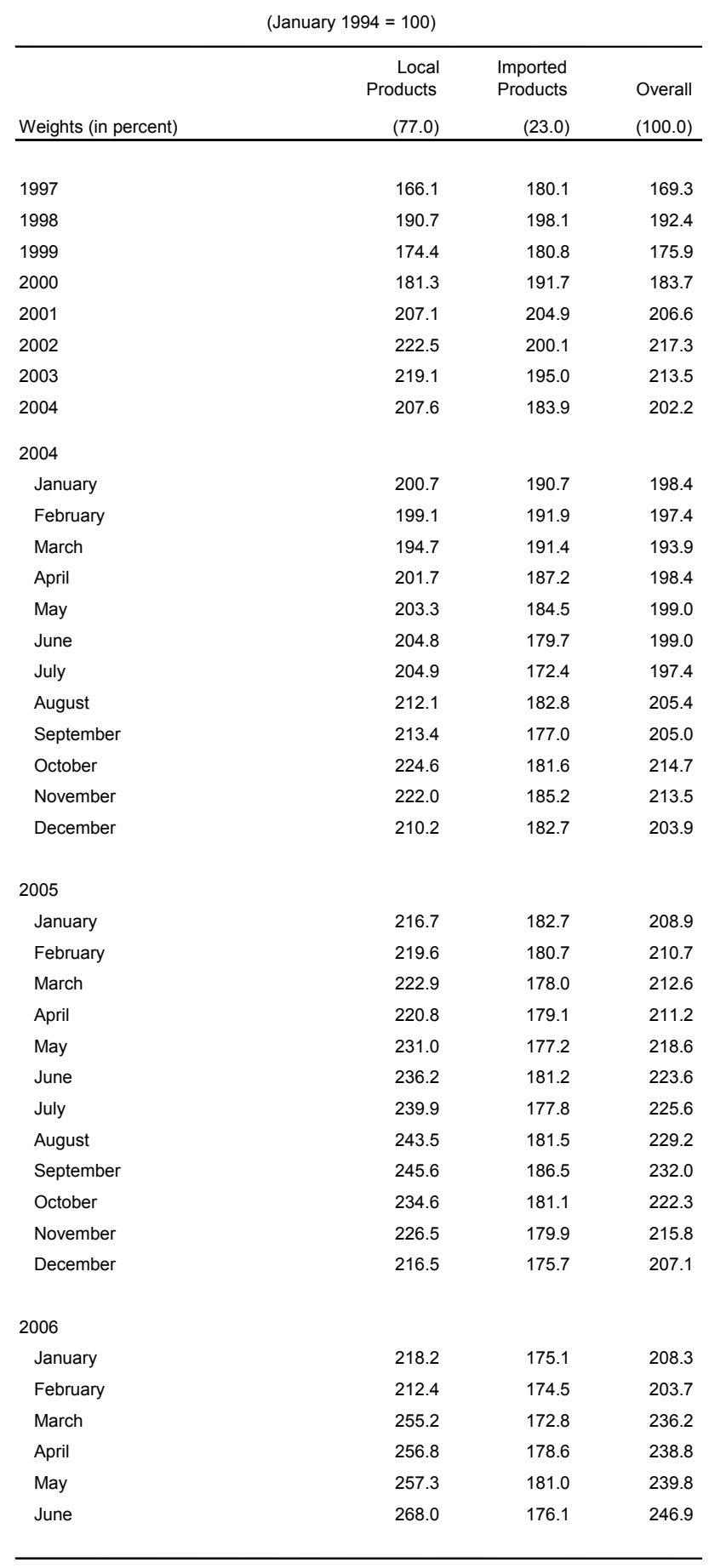

Sources: Chadian authorities; and IMF staff estimates. 
Table 6. Chad: Production of Main Food Crops, 1994/95-2004/05 1/

(In thousands of metric tons)

\begin{tabular}{|c|c|c|c|c|c|c|c|c|c|c|c|}
\hline & $1994 / 95$ & $1995 / 96$ & 1996/97 & $1997 / 98$ & 1998/99 & $1999 / 00$ & $2000 / 01$ & $2001 / 02$ & $2002 / 03$ & $2003 / 04$ & $2004 / 05$ \\
\hline Sudanian zone & 970 & 846 & 884 & 918 & 1,102 & 903 & 889 & 1,149 & 1,086 & 1,279 & 947 \\
\hline Cereals & 566 & 485 & 521 & 528 & 622 & 556 & 458 & 545 & 514 & 666 & 649 \\
\hline Millet & 120 & 86 & 110 & 79 & 88 & 93 & 81 & 110 & 109 & 146 & 149 \\
\hline Sorghum and berber & 306 & 291 & 279 & 322 & 381 & 289 & 275 & 298 & 239 & 276 & 299 \\
\hline Rice and maize & 140 & 108 & 132 & 128 & 153 & 174 & 102 & 137 & 166 & 244 & 201 \\
\hline Oils & 185 & 210 & 210 & 230 & 285 & 162 & 262 & 264 & 221 & 229 & 230 \\
\hline Groundnut & 163 & 206 & 203 & 212 & 263 & 144 & 240 & 229 & 203 & 216 & 218 \\
\hline Sesame & 22 & 4 & 7 & 18 & 22 & 18 & 22 & 35 & 18 & 13 & 12 \\
\hline Vegetables & 219 & 152 & 152 & 160 & 196 & 185 & 169 & 340 & 352 & 384 & 68 \\
\hline Fonio, niebe, and pois de ter & 38 & 32 & 33 & 33 & 60 & 38 & 61 & 64 & 57 & 79 & 37 \\
\hline Cassava & 181 & 119 & 119 & 127 & 136 & 147 & 108 & 276 & 295 & 305 & 31 \\
\hline Sahelian zone & 667 & 637 & 576 & 782 & 1,223 & 1,105 & 770 & 1,094 & 933 & 1,357 & 849 \\
\hline Cereals & 609 & 388 & 357 & 458 & 729 & 670 & 471 & 775 & 714 & 1,040 & 631 \\
\hline Millet & 200 & 142 & 148 & 170 & 270 & 268 & 178 & 288 & 249 & 370 & 145 \\
\hline Sorghum and berber & 297 & 210 & 165 & 199 & 307 & 341 & 236 & 404 & 408 & 577 & 415 \\
\hline Rice and maize & 109 & 33 & 40 & 84 & 148 & 59 & 55 & 80 & 53 & 90 & 71 \\
\hline Wheat & 3 & 3 & 4 & 5 & 5 & 3 & 3 & 4 & 4 & 3 & 0 \\
\hline Oils & 47 & 93 & 62 & 148 & 255 & 235 & 130 & 228 & 184 & 206 & 173 \\
\hline Groundnut & 44 & 87 & 57 & 140 & 248 & 228 & 119 & 219 & 177 & 198 & 167 \\
\hline Sesame & 4 & 6 & 6 & 8 & 7 & 7 & 11 & 9 & 7 & 8 & 6 \\
\hline Vegetables & 11 & 157 & 157 & 176 & 239 & 200 & 169 & 91 & 35 & 111 & 45 \\
\hline Fonio, niebe, and pois de ter & 6 & 8 & 8 & 18 & 70 & 17 & 35 & 63 & 6 & 67 & 14 \\
\hline Cassava & 4 & 148 & 148 & 158 & 169 & 183 & 134 & 28 & 29 & 44 & 31 \\
\hline Total cereals & 1,175 & 872 & 878 & 986 & 1,351 & 1,226 & 929 & 1,321 & 1,228 & 1,706 & 1,280 \\
\hline Total oils & 233 & 303 & 273 & 378 & 540 & 397 & 392 & 492 & 405 & 435 & 403 \\
\hline Total vegetables & 229 & 308 & 309 & 337 & 434 & 385 & 338 & 431 & 387 & 495 & 113 \\
\hline Total agricultural production & 1,637 & 1,484 & 1,460 & 1,700 & 2,325 & 2,008 & 1,659 & 2,243 & 2,019 & 2,636 & 1,796 \\
\hline
\end{tabular}

Sources: Chadian authorities; and IMF staff estimates.

$1 /$ Crop year starting in November. 
Table 7. Chad: Livestock Population, 1995-2004

\begin{tabular}{|c|c|c|c|c|c|c|c|c|c|c|}
\hline & 1995 & 1996 & 1997 & 1998 & 1999 & 2000 & 2001 & 2002 & 2003 & 2004 \\
\hline & \multicolumn{10}{|c|}{ (In thousands of head) } \\
\hline \multicolumn{11}{|l|}{ Size of herd } \\
\hline Cattle & 4,746 & 5,326 & 5,454 & 5,585 & 5,719 & 5,856 & 5,997 & 6,140 & 6,288 & 6,439 \\
\hline Sheep and goats & 6,025 & 6,613 & 6,754 & 6,980 & 7,191 & 7,367 & 7,569 & 7,776 & 7,989 & 8,208 \\
\hline Horses & 224 & 188 & 192 & 195 & 199 & 203 & 206 & 210 & 214 & 218 \\
\hline Camels & 613 & 626 & 642 & 659 & 676 & 694 & 712 & 731 & 750 & 770 \\
\hline Donkeys & 258 & 340 & 345 & 350 & 356 & 361 & 367 & 372 & 378 & 383 \\
\hline Pigs & 18 & 60 & 63 & 65 & 68 & 71 & 74 & 78 & 81 & 85 \\
\hline Total & 11,884 & 13,153 & 13,450 & 13,834 & 14,209 & 14,552 & 14,925 & 15,307 & 15,700 & 16,103 \\
\hline & \multicolumn{10}{|c|}{ (Annual percentage changes) } \\
\hline Cattle & 2.0 & 12.2 & 2.4 & 2.4 & 2.4 & 2.4 & 2.4 & 2.4 & 2.4 & 2.4 \\
\hline Sheep and goats & 3.0 & 9.8 & 2.1 & 3.3 & 3.0 & 2.4 & 2.7 & 2.7 & 2.7 & 2.7 \\
\hline Horses & 4.7 & -16.1 & 2.1 & 1.6 & 2.1 & 2.0 & 1.5 & 1.9 & 1.9 & 1.9 \\
\hline Camels & 3.0 & 2.1 & 2.6 & 2.6 & 2.6 & 2.7 & 2.6 & 2.7 & 2.6 & 2.7 \\
\hline Donkeys & 2.0 & 31.8 & 1.5 & 1.4 & 1.7 & 1.4 & 1.7 & 1.4 & 1.6 & 1.3 \\
\hline Pigs & 5.9 & 233.3 & 5.0 & 3.2 & 4.6 & 4.4 & 4.2 & 5.4 & 3.8 & 4.9 \\
\hline Total & 2.6 & 10.7 & 2.3 & 2.9 & 2.7 & 2.4 & 2.6 & 2.6 & 2.6 & 2.6 \\
\hline
\end{tabular}

Sources: Chadian authorities; and IMF staff estimates. 


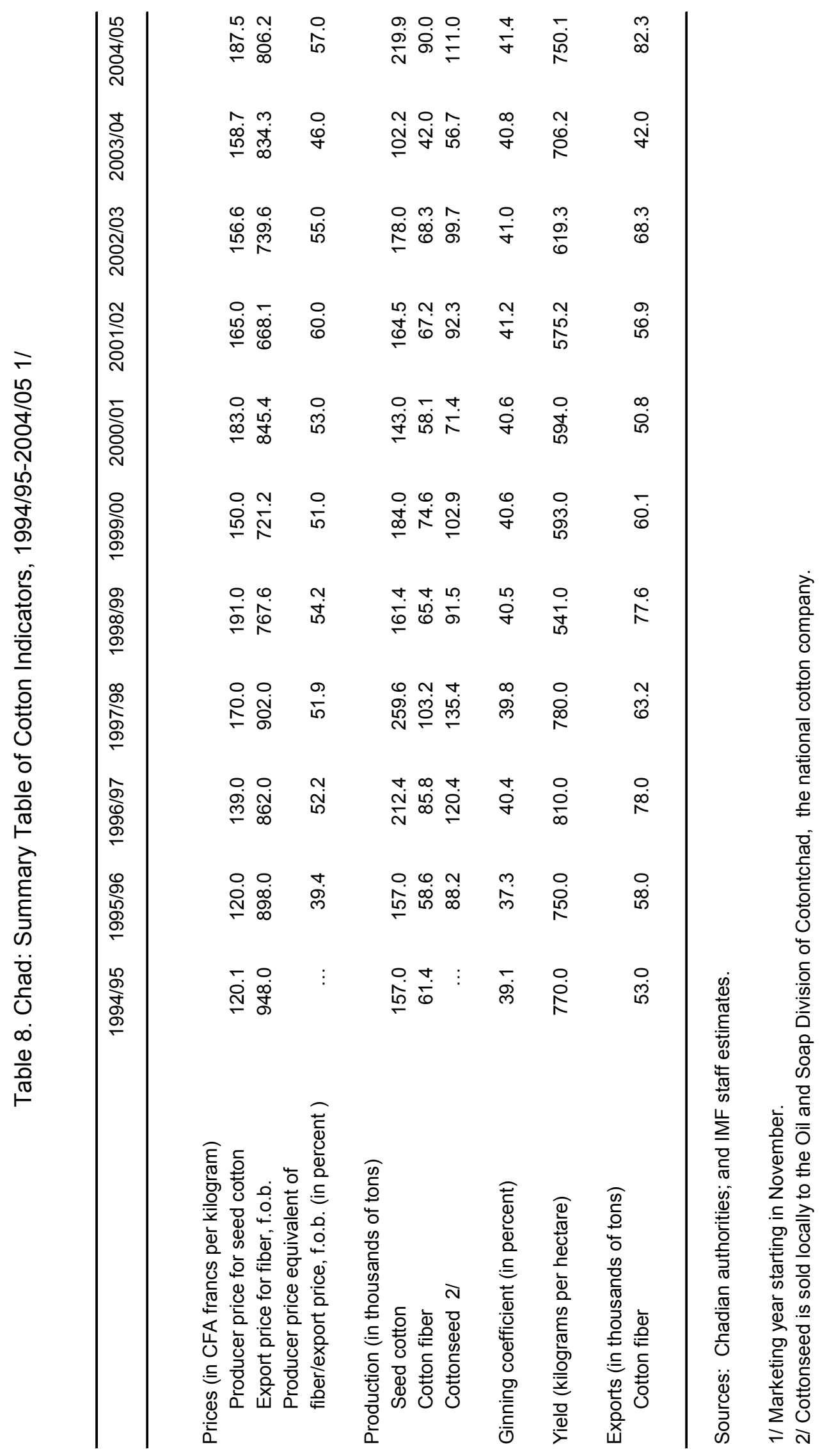


Table 9. Chad: Cotton Production, Cost, and Revenue, 1997/98-2004/05 1/

(In units indicated)

\begin{tabular}{|c|c|c|c|c|c|c|c|c|}
\hline & $1997 / 98$ & 1998/99 & 1999/00 & $2000 / 01$ & $2001 / 02$ & $2002 / 03$ & $2003 / 04$ & $2004 / 05$ \\
\hline Production of seedcotton (1) $2 /$ & 259.6 & 161.4 & 184.0 & 143.0 & 164.5 & 178.0 & 102.2 & 219.9 \\
\hline Production of fiber (2) $2 /$ & 103.2 & 65.4 & 74.6 & 58.1 & 67.2 & 68.3 & 42.0 & 90.0 \\
\hline Fiber yield $(3)=(2) /(1)$ & 0.40 & 0.41 & 0.41 & 0.41 & 0.41 & 0.38 & 0.41 & 0.41 \\
\hline Export volume of cotton fiber $2 /$ & 78.0 & 63.2 & 77.6 & 60.1 & 50.8 & 56.9 & 68.3 & 42.0 \\
\hline Producer price (4) $3 /$ & 191.5 & 168.8 & 149.4 & 181.9 & 165.0 & 156.6 & 158.7 & 187.5 \\
\hline Fiber equivalent of producer price $(5)=(4) /(3) 3 /$ & 481.7 & 416.6 & 368.7 & 447.9 & 404.0 & 408.1 & 386.1 & 458.0 \\
\hline Other unit production costs(6) $3 /$ & 429.3 & 431.0 & 407.8 & 471.5 & 451.1 & 67.0 & 40.3 & 34.7 \\
\hline Marketing cost & 45.3 & 55.5 & 47.6 & 65.8 & 50.2 & $\ldots$ & $\ldots$ & 0.0 \\
\hline Ginning and storage cost & 60.4 & 54.1 & 56.0 & 57.5 & 85.3 & $\ldots$ & $\ldots$ & $\ldots$ \\
\hline Insurance, freight, and other export costs & 81.8 & 75.4 & 71.3 & 74.8 & 74.8 & 67.0 & 40.3 & 34.7 \\
\hline Financial cost & 20.2 & 31.0 & 23.8 & 19.1 & 43.0 & $\ldots$ & $\ldots$ & 0.0 \\
\hline Other costs $4 /$ & 221.6 & 215.0 & 209.2 & 254.3 & 197.8 & $\ldots$ & $\ldots$ & $\ldots$ \\
\hline Total unit cost of cotton fiber $(7)=(5)+(6) 3 /$ & 911.0 & 847.6 & 776.6 & 919.3 & 855.0 & 475.1 & 426.4 & 492.7 \\
\hline \multicolumn{9}{|l|}{ Average sale price of cotton fiber $3 / 5 /$} \\
\hline f.o.b. & 902.0 & 767.6 & 721.2 & 845.4 & 668.1 & 739.6 & 834.3 & 806.2 \\
\hline c.i.f. & 953.0 & 822.9 & 741.1 & 893.4 & 710.5 & 774.1 & 867.5 & 878.2 \\
\hline Total revenue (in billions of CFA francs) & 88.6 & 49.3 & 54.0 & 52.1 & 51.5 & 49.6 & 34.2 & 74.8 \\
\hline Cotton fiber & $\ldots$ & 40.1 & 38.0 & 50.8 & 45.2 & 49.6 & 34.2 & 74.8 \\
\hline Cottonseed & $\ldots$ & $\ldots$ & $\ldots$ & $\ldots$ & 1.8 & $\ldots$ & $\ldots$ & $\ldots$ \\
\hline Other & $\ldots$ & 9.1 & 15.9 & 1.3 & 4.5 & $\ldots$ & $\ldots$ & $\ldots$ \\
\hline Total cost off cotton fiber (in billions of CFA francs) & 88.7 & 55.5 & 57.9 & 53.4 & 55.4 & 83.7 & 57.4 & 51.6 \\
\hline Gross profit (in billions of CFA francs) & -0.1 & -6.2 & -3.9 & -1.3 & -3.9 & -34.1 & -23.2 & 23.2 \\
\hline \multicolumn{9}{|l|}{ Memorandum items: } \\
\hline Fixed costs $3 /$ & $\ldots$ & 155.2 & 143.7 & 169.9 & 171.0 & 95.0 & 85.3 & 98.5 \\
\hline Variable costs $3 /$ & $\ldots$ & 692.3 & 632.9 & 749.4 & 684.0 & 380.1 & 341.1 & 394.2 \\
\hline World cotton price (WEO) $3 /$ & 924.3 & 737.8 & 825.1 & 867.2 & 668.4 & 778.6 & 812.5 & 617.1 \\
\hline Equilibrium purchasing price for producers $3 / 6 /$ & 191.1 & 130.4 & 128.2 & 172.8 & 141.3 & -34.7 & -68.6 & 292.9 \\
\hline
\end{tabular}

Sources: Chadian authorities; and IMF staff estimates.

1/ Marketing year starting in November.

2/ Thousands of metric tons.

3/ CFA francs per kilogram.

4/ Including fixed costs, international transport cost, and other costs.

5/ Excluding price paid to producers for seed cotton, but including the other purchase costs of seed cotton.

6/ Producer price that equilibrates revenues and costs. 


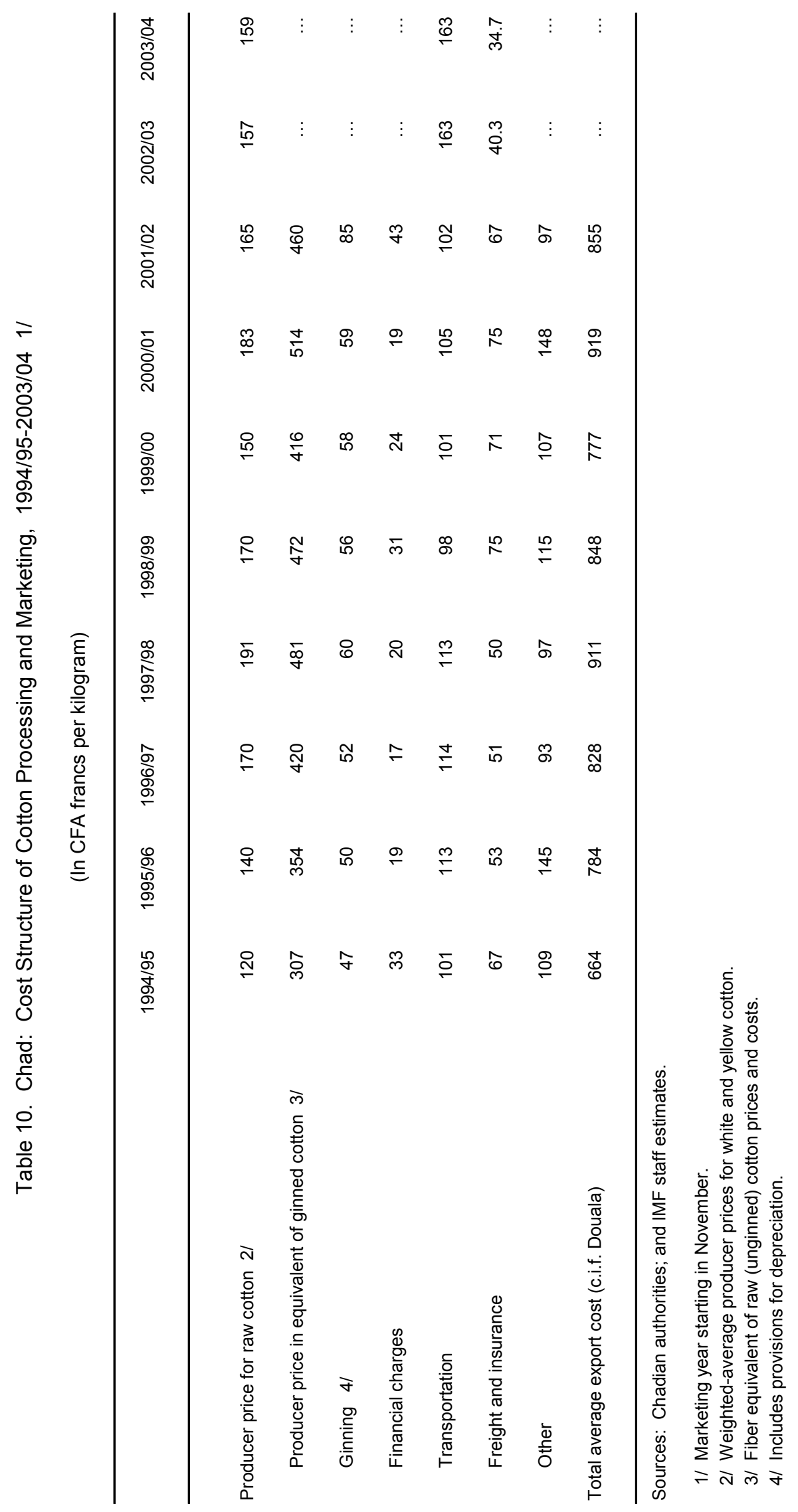




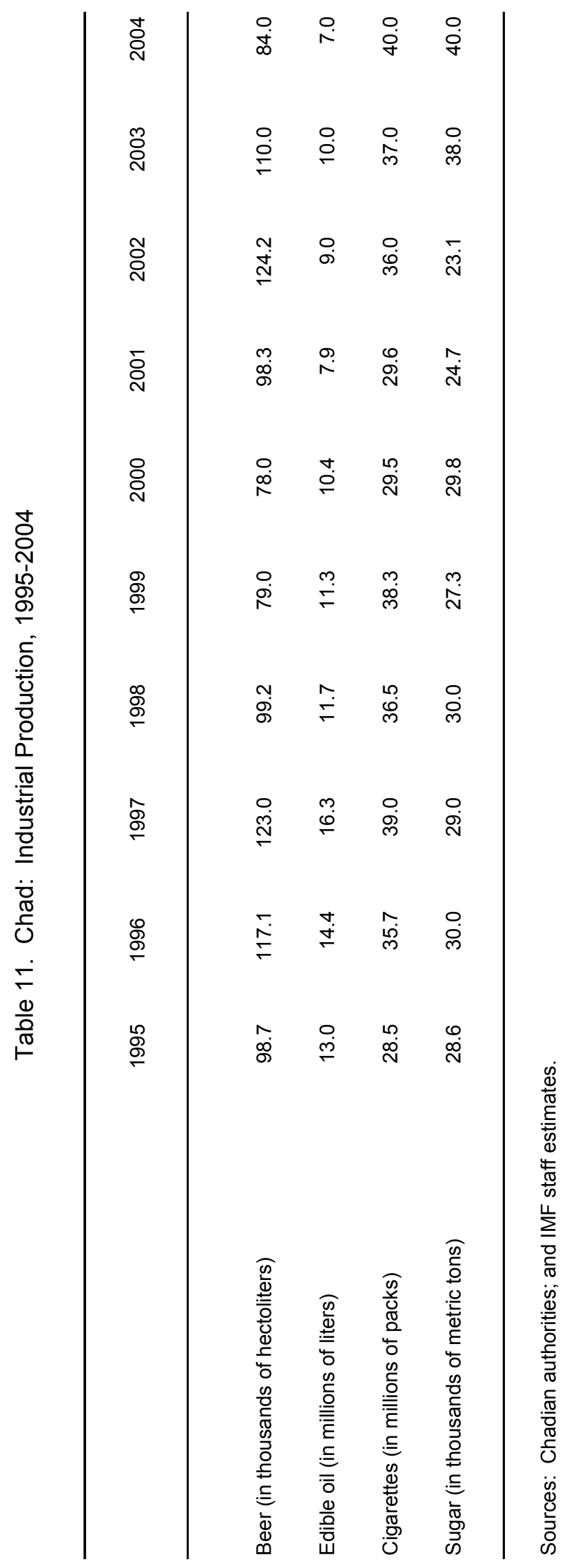




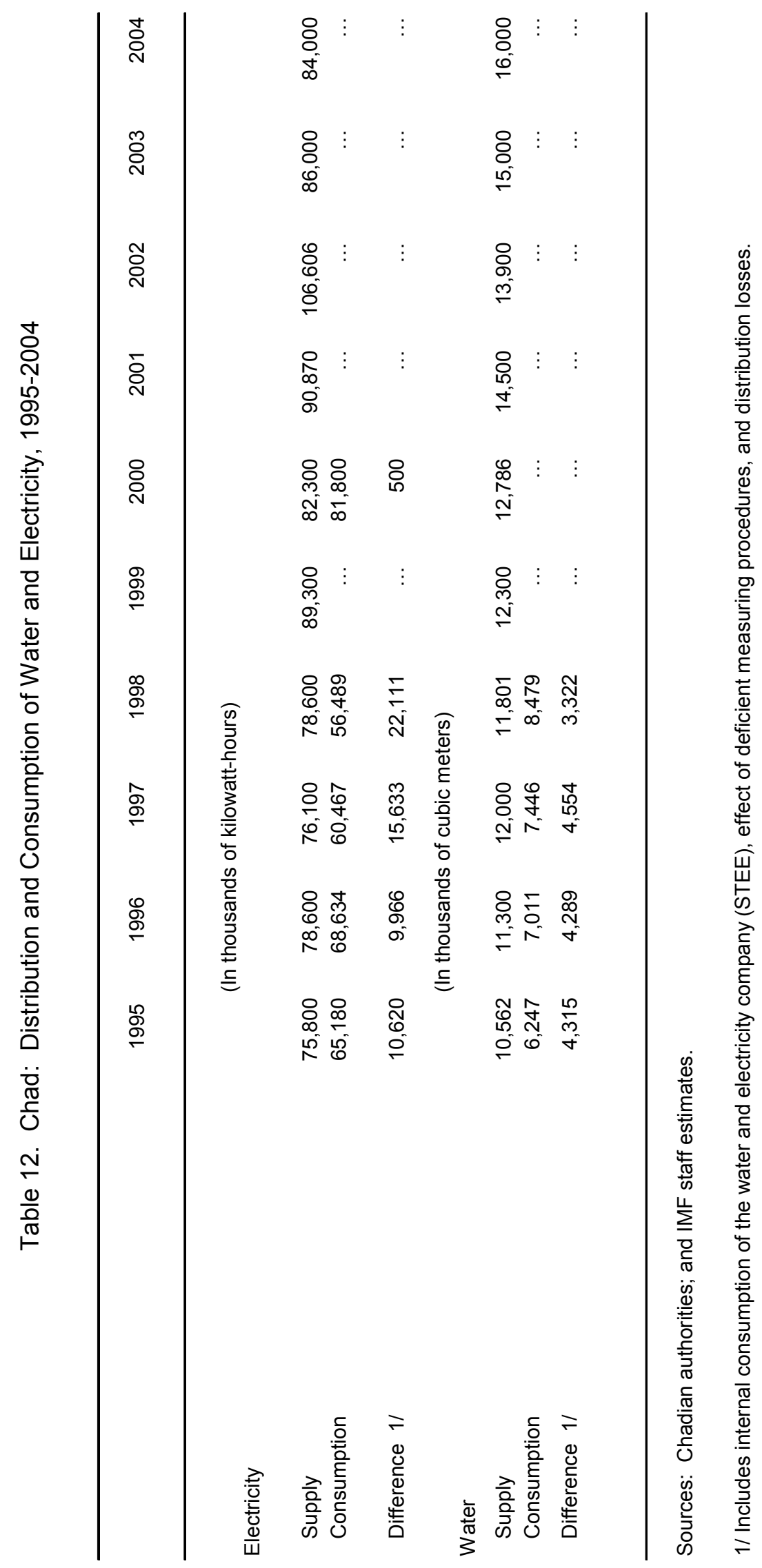


Table 13. Chad: Consolidated Fiscal Operations, 1998-2005

(in billions of CFA francs)

\begin{tabular}{|c|c|c|c|c|c|c|c|c|}
\hline & 1998 & 1999 & 2000 & 2001 & 2002 & 2003 & 2004 & 2005 \\
\hline Revenue & 76.2 & 77.7 & 80.2 & 91.7 & 112.4 & 124.6 & 198.0 & 289.7 \\
\hline Oil royalties, dividends, and income tax $2 /$ & 0.0 & 0.0 & 0.0 & 0.0 & 0.0 & 0.0 & 57.7 & 130.4 \\
\hline Non-oil Tax revenue & 69.8 & 68.0 & 68.3 & 78.6 & 100.9 & 113.4 & 122.0 & 138.9 \\
\hline Non-Tax revenue $3 /$ & 6.5 & 9.7 & 11.9 & 13.1 & 11.6 & 11.2 & 18.3 & 20.4 \\
\hline Expenditure & 153.3 & 178.8 & 203.2 & 220.3 & 280.3 & 348.0 & 336.8 & 404.9 \\
\hline Current expenditure & 75.0 & 87.9 & 99.9 & 109.8 & 140.0 & 149.4 & 154.7 & 187.3 \\
\hline Wages and salaries & 39.8 & 45.1 & 48.7 & 56.7 & 62.1 & 73.6 & 80.1 & 101.2 \\
\hline Civil service & 31.5 & 34.0 & 38.5 & 44.3 & 48.9 & 56.2 & 60.9 & 73.3 \\
\hline Military & 8.3 & 11.2 & 10.2 & 12.4 & 13.2 & 17.4 & 19.2 & 27.9 \\
\hline Goods and services & 17.3 & 20.2 & 25.7 & 29.4 & 34.9 & 42.6 & 32.4 & 34.2 \\
\hline Transfers & 8.6 & 13.8 & 13.5 & 6.9 & 21.3 & 19.2 & 30.1 & 37.1 \\
\hline Food security & 0.8 & 0.0 & 0.0 & 3.1 & 0.0 & 1.7 & 0.0 & 0.9 \\
\hline Elections & 0.0 & 0.1 & 0.4 & 4.7 & 2.0 & 0.0 & 2.0 & 2.7 \\
\hline Other current expenditure & 0.0 & 0.0 & 1.3 & 0.0 & 7.7 & 2.9 & 0.0 & 0.8 \\
\hline Interest & 8.4 & 8.7 & 10.3 & 9.1 & 12.0 & 9.5 & 10.2 & 10.4 \\
\hline Domestic & 1.3 & 1.1 & 1.4 & 0.6 & 1.3 & 0.9 & 1.9 & 3.2 \\
\hline External & 7.1 & 7.6 & 8.9 & 8.6 & 10.6 & 8.6 & 8.2 & 7.2 \\
\hline Investment expenditure & 78.4 & 90.9 & 103.3 & 110.5 & 140.3 & 198.6 & 182.1 & 217.7 \\
\hline Domestically financed & 5.0 & 8.8 & 10.7 & 11.4 & 16.9 & 28.9 & 48.7 & 68.5 \\
\hline Foreign financed & 73.3 & 82.1 & 92.6 & 99.1 & 123.5 & 169.7 & 133.4 & 149.1 \\
\hline Non-oil primary balance (excl. grants, commitment basis) $4 /$ & 4.7 & -10.4 & -20.1 & -20.5 & -32.5 & -44.2 & -53.0 & -86.2 \\
\hline Overall balance (excl. grants, commitments) & -77.1 & -101.1 & -123.0 & -128.6 & -167.9 & -223.4 & -138.8 & -115.3 \\
\hline Arrears & -5.6 & -4.9 & -2.6 & 9.3 & -6.5 & 3.6 & 21.6 & 4.2 \\
\hline External interest & -0.7 & 0.0 & 1.2 & -0.9 & 0.4 & -0.5 & 1.0 & -0.6 \\
\hline Domestic arrears & -4.9 & -4.9 & -3.7 & 10.2 & -6.9 & 4.1 & 20.6 & 4.8 \\
\hline Previous years arrears & $\ldots$ & $\ldots$ & $\ldots$ & $\ldots$ & $\ldots$ & $\ldots$ & -23.8 & -42.5 \\
\hline Current year arrears & $\ldots$ & $\ldots$ & $\ldots$ & $\ldots$ & $\ldots$ & $\ldots$ & 44.4 & 47.3 \\
\hline Errors and omissions & 0.0 & 0.0 & 0.0 & -2.1 & 0.8 & 0.0 & -3.7 & -22.9 \\
\hline Overall balance (excl. grants, cash) & -80.1 & -105.5 & -123.8 & -121.4 & -173.6 & -219.8 & -120.9 & -134.0 \\
\hline Financing & 44.8 & 105.5 & 123.8 & 121.4 & 173.6 & 219.8 & 120.9 & 134.0 \\
\hline Domestic financing & 2.5 & 9.7 & 35.9 & 6.5 & 1.8 & 20.5 & -16.6 & -23.5 \\
\hline Central Bank (BEAC) & -7.9 & 11.7 & 12.0 & 7.3 & 7.7 & 8.9 & -12.5 & 2.7 \\
\hline Ut which: UII revenue accounts $b /$ & 0.0 & 0.0 & 0.0 & 0.0 & 0.0 & 0.0 & -12.9 & -9.7 \\
\hline Ot which: Advances (net) & 0.0 & 0.0 & 0.0 & 0.0 & 0.6 & 0.0 & 11.1 & 15.4 \\
\hline Ot which: IMF (net) 6/ & 0.0 & 0.0 & 0.0 & 0.0 & 7.0 & -6.4 & -7.1 & -3.8 \\
\hline Commercial banks & 9.8 & -2.0 & 7.3 & 2.5 & 0.0 & 4.7 & -1.4 & -6.7 \\
\hline Non-bank financing $7 /$ & 0.0 & 0.0 & 3.7 & -3.3 & -6.2 & -4.9 & -2.7 & -19.5 \\
\hline Privatization & 0.6 & 0.0 & 12.9 & 0.0 & 0.5 & 11.8 & 0.0 & 0.0 \\
\hline Foreign financing & 42.3 & 95.8 & 87.9 & 114.9 & 171.8 & 199.3 & 137.5 & 157.5 \\
\hline Grants & 50.9 & 44.6 & 55.2 & 63.8 & 84.9 & 122.7 & 69.4 & 104.2 \\
\hline Budget support grants & 12.8 & 1.8 & 7.2 & 15.5 & 10.5 & 6.8 & 4.6 & 13.1 \\
\hline Project grants & 38.1 & 42.9 & 48.0 & 48.2 & 74.4 & 115.9 & 64.8 & 91.1 \\
\hline Loans (net) & -8.6 & 51.2 & 32.8 & 51.1 & 86.8 & 76.6 & 68.0 & 53.3 \\
\hline Disbursements & & 64.7 & 44.6 & 50.8 & 89.9 & 81.1 & 81.4 & 58.1 \\
\hline Amortization & -10.2 & -14.7 & -14.1 & -15.2 & -21.9 & -13.2 & -20.0 & -11.5 \\
\hline External arrears (principal) & -4.1 & 0.0 & 2.3 & -1.5 & 4.7 & -1.8 & 0.3 & -1.9 \\
\hline Debt relief & 5.7 & 1.2 & 0.0 & 17.0 & 14.2 & 10.5 & 6.4 & 8.7 \\
\hline Fund disbursement & -4.0 & -3.0 & -2.0 & -1.0 & 0.0 & 0.0 & 0.0 & 0.0 \\
\hline Remaining financing gap & -35.3 & 0.0 & 0.0 & 0.0 & 0.0 & 0.0 & 0.0 & 0.0 \\
\hline
\end{tabular}

Sources: Chadian authorities; and IMF staff estimates.

$1 /$ In the program, revenue from oil exploration permit was recorded under sale of assets.

from oil exploration permit in non tax revenue.

2/ Oil export price per barrel used in the budget is US\$3 dollar below current World Economic Outlook projection with a discount for quality.

$3 /$ Include revenue from oil exploration permit and share premium.

4/ Defined as the total revenue excluding grants and oil revenue, minus total expenditure excluding interest payments and foreign-financed investment.

5/ Fund for Future Generations, Stabilization, and Oil Producing Region.

6/ For 2006, shown gross of Fund disbursement.

7/ Include restructured debt as specified in the technical memorandum of understanding under the PRGF-supported program

(excluding BEAC (Bank of Central African States) and CBT (Commercial Bank of Chad)), as well as payment on new domestic debt conventions. 
Table 14. Chad: Consolidated Fiscal Operations, 1998-2005

(In percent of non-oil GDP, unless otherwise indicated)

\begin{tabular}{|c|c|c|c|c|c|c|c|c|}
\hline & 1998 & 1999 & 2000 & 2001 & 2002 & 2003 & 2004 & 2005 \\
\hline Revenue & 7.4 & 8.2 & 8.2 & 7.5 & 8.4 & 9.1 & 14.4 & 17.3 \\
\hline Oil royalties, dividends, and income tax $2 /$ & 0.0 & 0.0 & 0.0 & 0.0 & 0.0 & 0.0 & 4.2 & 7.8 \\
\hline Non-oil Tax revenue & 6.8 & 7.2 & 6.9 & 6.4 & 7.5 & 8.3 & 8.9 & 8.3 \\
\hline Non-Tax revenue $3 /$ & 0.6 & 1.0 & 1.2 & 1.1 & 0.9 & 0.8 & 1.3 & 1.2 \\
\hline Expenditure & 14.9 & 19.0 & 20.7 & 17.9 & 20.9 & 25.5 & 24.5 & 24.2 \\
\hline Current expenditure & 7.3 & 9.3 & 10.2 & 8.9 & 10.4 & 11.0 & 11.3 & 11.2 \\
\hline Wages and salaries & 3.9 & 4.8 & 5.0 & 4.6 & 4.6 & 5.4 & 5.8 & 6.0 \\
\hline Civil service & 3.1 & 3.6 & 3.9 & 3.6 & 3.6 & 4.1 & 4.4 & 4.4 \\
\hline Military & 0.8 & 1.2 & 1.0 & 1.0 & 1.0 & 1.3 & 1.4 & 1.7 \\
\hline Goods and services & 1.7 & 2.1 & 2.6 & 2.4 & 2.6 & 3.1 & 2.4 & 2.0 \\
\hline Transfers & 0.8 & 1.5 & 1.4 & 0.6 & 1.6 & 1.4 & 2.2 & 2.2 \\
\hline Food security & 0.1 & 0.0 & 0.0 & 0.2 & 0.0 & 0.1 & 0.0 & 0.1 \\
\hline Elections & 0.0 & 0.0 & 0.0 & 0.4 & 0.2 & 0.0 & 0.1 & 0.2 \\
\hline Other current expenditure & 0.0 & 0.0 & 0.1 & 0.0 & 0.6 & 0.2 & 0.0 & 0.0 \\
\hline Interest & 0.8 & 0.9 & 1.1 & 0.7 & 0.9 & 0.7 & 0.7 & 0.6 \\
\hline Domestic & 0.1 & 0.1 & 0.1 & 0.0 & 0.1 & 0.1 & 0.1 & 0.2 \\
\hline External & 0.7 & 0.8 & 0.9 & 0.7 & 0.8 & 0.6 & 0.6 & 0.4 \\
\hline Investment expenditure & 7.6 & 9.6 & 10.5 & 9.0 & 10.5 & 14.6 & 13.2 & 13.0 \\
\hline Domestically financed & 0.5 & 0.9 & 1.1 & 0.9 & 1.3 & 2.1 & 3.5 & 4.1 \\
\hline Foreign financed & 7.1 & 8.7 & 9.4 & 8.1 & 9.2 & 12.4 & 9.7 & 8.9 \\
\hline Non-oil primary balance (excl. grants, commitment basis) 4/ & 0.5 & -1.1 & -2.0 & -1.7 & -2.4 & -3.2 & -3.9 & -5.1 \\
\hline Overall balance (excl. grants, commitments) & -7.5 & -10.7 & -12.5 & -10.5 & -12.5 & -16.4 & -10.1 & -6.9 \\
\hline Arrears & -0.5 & -0.5 & -0.3 & 0.8 & -0.5 & 0.3 & 1.6 & 0.3 \\
\hline External interest & -0.1 & 0.0 & 0.1 & -0.1 & 0.0 & 0.0 & 0.1 & 0.0 \\
\hline Domestic arrears & -0.5 & -0.5 & -0.4 & 0.8 & -0.5 & 0.3 & 1.5 & 0.3 \\
\hline Previous years arrears & $\cdots$ & $\ldots$ & $\cdots$ & $\ldots$ & $\cdots$ & $\ldots$ & -1.7 & -2.5 \\
\hline Current year arrears & $\ldots$ & $\ldots$ & $\ldots$ & $\ldots$ & $\ldots$ & $\ldots$ & 3.2 & 2.8 \\
\hline Errors and omissions & 0.0 & 0.0 & 0.0 & -0.2 & 0.1 & 0.0 & -0.3 & -1.4 \\
\hline Overall balance (excl. grants, cash) & -7.8 & -11.2 & -12.6 & -9.9 & -12.9 & -16.1 & -8.8 & -8.0 \\
\hline Financing & & & & 9.9 & 12.9 & 16.1 & 8.8 & 8.0 \\
\hline Domestic financing & 1.0 & -0.2 & 2.4 & -0.1 & 0.1 & 1.5 & -1.2 & -1.4 \\
\hline Central Bank (BEAC) & 0.0 & 0.0 & 0.0 & 0.0 & 0.6 & 0.7 & -0.9 & 0.2 \\
\hline Ut which: Ull revenue accounts $b /$ & 0.0 & 0.0 & 0.0 & 0.0 & 0.0 & 0.0 & -0.9 & -0.6 \\
\hline Ut whıch: Advances (net) & 0.0 & 0.0 & 0.0 & 0.0 & 0.0 & 0.0 & 0.8 & 0.9 \\
\hline Ut which: IMr (net) 6/ & 0.0 & 0.0 & 0.0 & 0.0 & 0.5 & -0.5 & -0.5 & -0.2 \\
\hline Commercial banks & 1.0 & -0.2 & 0.7 & 0.2 & 0.0 & 0.3 & -0.1 & -0.4 \\
\hline Non-bank financing $7 /$ & 0.0 & 0.0 & 0.4 & -0.3 & -0.5 & -0.4 & -0.2 & -1.2 \\
\hline Privatization & 0.1 & 0.0 & 1.3 & 0.0 & 0.0 & 0.9 & 0.0 & 0.0 \\
\hline Foreign financing & & & & 9.3 & 12.8 & 14.6 & 10.0 & 9.4 \\
\hline Grants & 5.0 & 4.7 & 5.6 & 5.2 & 6.3 & 9.0 & 5.0 & 6.2 \\
\hline Budget support grants & 1.2 & 0.2 & 0.7 & 1.3 & 0.8 & 0.5 & 0.3 & 0.8 \\
\hline Project grants & 3.7 & 4.5 & 4.9 & 3.9 & 5.5 & 8.5 & 4.7 & 5.4 \\
\hline Loans (net) & & & & 4.2 & 6.5 & 5.6 & 4.9 & 3.2 \\
\hline Disbursements & & 6.9 & 4.5 & 4.1 & 6.7 & 5.9 & 5.9 & 3.5 \\
\hline Budget support loans & & 2.7 & 0.0 & 0.0 & 3.0 & 2.0 & 0.9 & 0.0 \\
\hline Project loans & 3.4 & 4.2 & 4.5 & 4.1 & 3.7 & 3.9 & 5.0 & 3.5 \\
\hline Amortization & -1.0 & -1.6 & -1.4 & -1.2 & -1.6 & -1.0 & -1.5 & -0.7 \\
\hline External arrears (principal) & -0.4 & 0.0 & 0.2 & -0.1 & 0.4 & -0.1 & 0.0 & -0.1 \\
\hline Debt relief & & & & 1.4 & 1.1 & 0.8 & 0.5 & 0.5 \\
\hline HIPC & & & & 0.5 & 0.7 & 0.7 & 0.5 & 0.5 \\
\hline Other debt relief & 0.6 & 0.1 & 0.0 & 0.9 & 0.3 & 0.1 & 0.0 & 0.0 \\
\hline Fund disbursement & -0.4 & -0.3 & -0.2 & -0.1 & 0.0 & 0.0 & 0.0 & 0.0 \\
\hline Kemaınıng tınancıng gap & U.U & U.U & U.U & U.U & U.U & U.U & U.U & u.u \\
\hline \multicolumn{9}{|l|}{ Memorandum item: } \\
\hline Non-oil GDP (in billions of CFA francs) & 1027.7 & 943.4 & 984.0 & 1229.4 & 1341.9 & 1363.3 & 1375.2 & 1676.3 \\
\hline
\end{tabular}

Sources: Chadian authorities; and IMF staff estimates.

$1 /$ In the program, revenue from oil exploration permit was recorded under sale of assets.

from oil exploration permit in non tax revenue.

2/ Oil export price per barrel used in the budget is US $\$ 3$ dollar below current World Economic Outlook projection with a discount for quality.

$3 /$ Include revenue from oil exploration permit and share premium.

4/ Defined as the total revenue excluding grants and oil revenue, minus total expenditure excluding interest payments and foreign-financed investment.

5/ Fund for Future Generations, Stabilization, and Oil Producing Region.

6/ For 2006, shown gross of Fund disbursement.

$7 /$ Include restructured debt as specified in the technical memorandum of understanding under the PRGF-supported program

(excluding BEAC (Bank of Central African States) and CBT (Commercial Bank of Chad)), as well as payment on new domestic debt conventions. 
Table 15. Chad: Government Revenue, 1998-2005

\begin{tabular}{|c|c|c|c|c|c|c|c|c|}
\hline & 1998 & 1999 & 2000 & 2001 & 2002 & 2003 & 2004 & 2005 \\
\hline & \multicolumn{8}{|c|}{ (In billions of CFA francs) } \\
\hline Total revenue & 76.2 & 77.7 & 80.2 & 91.7 & 112.4 & 124.6 & 198.0 & 289.7 \\
\hline Non-oil revenue & 76.2 & 77.7 & 80.2 & 91.7 & 112.4 & 124.6 & 140.3 & 159.2 \\
\hline Tax revenue & 69.7 & 68.0 & 68.3 & 78.6 & 100.9 & 113.4 & 122.0 & 138.9 \\
\hline Taxes on income and profits & 22.6 & 23.8 & 22.7 & 28.2 & 42.7 & 52.4 & 52.5 & 58.9 \\
\hline Companies & 10.7 & 12.4 & 11.3 & 12.5 & 19.0 & 20.3 & 23.5 & 24.2 \\
\hline Individuals & 10.6 & 10.0 & 10.0 & 12.6 & 21.8 & 30.2 & 26.9 & 32.4 \\
\hline Employers' payroll tax & 1.4 & 1.4 & 1.5 & 3.1 & 2.0 & 1.9 & 2.1 & 2.3 \\
\hline Property tax & 0.7 & 1.3 & 1.6 & 1.8 & 2.6 & 2.5 & 4.1 & 4.2 \\
\hline Taxes on goods and services & 12.1 & 15.8 & 18.8 & 19.7 & 19.5 & 20.6 & 25.9 & 26.0 \\
\hline Turnover tax & 8.5 & 8.8 & 11.7 & 13.0 & 13.6 & 14.4 & 15.4 & 17.9 \\
\hline Tax on petroleum products & 3.5 & 4.1 & 6.0 & 4.1 & 4.4 & 4.7 & 5.1 & 5.4 \\
\hline Other & 0.0 & 3.0 & 1.1 & 2.6 & 1.6 & 1.5 & 5.5 & 2.7 \\
\hline Taxes on international trade & 27.4 & 23.0 & 21.8 & 27.2 & 30.8 & 31.3 & 33.8 & 41.1 \\
\hline Import taxes & 25.7 & 19.9 & 18.5 & 23.5 & 27.2 & 27.6 & 29.5 & 37.1 \\
\hline Export taxes & 1.3 & 2.1 & 2.2 & 2.3 & 1.6 & 1.6 & 2.0 & 1.6 \\
\hline Other & 0.5 & 1.1 & 1.1 & 1.5 & 2.0 & 2.0 & 2.4 & 2.4 \\
\hline Other tax revenues & 7.0 & 4.1 & 3.4 & 1.6 & 5.2 & 6.6 & 5.6 & 8.7 \\
\hline Nontax revenue & 6.5 & 9.7 & 11.9 & 13.1 & 11.6 & 11.2 & 18.3 & 20.4 \\
\hline Property income & 1.3 & 0.9 & 1.9 & 2.4 & 1.6 & 2.1 & 2.9 & 1.0 \\
\hline Administrative fees & 0.4 & 2.2 & 2.6 & 4.4 & 1.9 & 1.9 & 1.2 & 2.3 \\
\hline Nonindustrial sales & 1.3 & 1.8 & 1.7 & 1.9 & 2.3 & 2.2 & 3.3 & 2.0 \\
\hline Oil exploration permit and share premium & 0.0 & 0.0 & 0.0 & 0.0 & 0.0 & 0.0 & 8.3 & 13.6 \\
\hline Other & 3.5 & 4.9 & 5.8 & 4.5 & 5.8 & 5.1 & 2.6 & 1.5 \\
\hline \multirow[t]{2}{*}{ Oil revenue } & 0.0 & 0.0 & 0.0 & 0.0 & 0.0 & 0.0 & 57.7 & 130.4 \\
\hline & \multicolumn{8}{|c|}{ (In percent of total revenue) } \\
\hline Total revenue & 100.0 & 100.0 & 100.0 & 100.0 & 100.0 & 100.0 & 100.0 & 100.0 \\
\hline Tax revenue & 91.5 & 87.5 & 85.1 & 85.7 & 89.7 & 91.0 & 61.6 & 47.9 \\
\hline Taxes on income and profits & 29.7 & 30.7 & 28.3 & 30.8 & 38.0 & 42.1 & 26.5 & 20.3 \\
\hline Companies & 14.0 & 16.0 & 14.1 & 13.6 & 16.9 & 16.3 & 11.9 & 8.3 \\
\hline Individuals & 13.8 & 12.9 & 12.4 & 13.8 & 19.4 & 24.2 & 13.6 & 11.2 \\
\hline Employers' payroll tax & 1.8 & 1.8 & 1.8 & 3.4 & 1.7 & 1.6 & 1.0 & 0.8 \\
\hline Property tax & 0.9 & 1.6 & 2.0 & 2.0 & 2.3 & 2.0 & 2.1 & 1.5 \\
\hline Taxes on goods and services & 15.8 & 20.3 & 23.4 & 21.5 & 17.4 & 16.6 & 13.1 & 9.0 \\
\hline Turnover tax & 11.2 & 11.3 & 14.6 & 14.2 & 12.1 & 11.5 & 7.8 & 6.2 \\
\hline Tax on petroleum products & 4.6 & 5.2 & 7.5 & 4.4 & 3.9 & 3.8 & 2.6 & 1.9 \\
\hline Other & 0.0 & 3.8 & 1.4 & 2.8 & 1.4 & 1.2 & 2.8 & 0.9 \\
\hline Taxes on international trade & 36.0 & 29.6 & 27.2 & 29.7 & 27.4 & 25.1 & 17.1 & 14.2 \\
\hline Import taxes & 33.7 & 25.6 & 23.1 & 25.6 & 24.2 & 22.2 & 14.9 & 12.8 \\
\hline Export taxes & 1.7 & 2.7 & 2.7 & 2.5 & 1.4 & 1.3 & 1.0 & 0.6 \\
\hline Other & 0.6 & 1.4 & 1.3 & 1.7 & 1.8 & 1.6 & 1.2 & 0.8 \\
\hline Other tax revenues & 9.2 & 5.2 & 4.2 & 1.7 & 4.7 & 5.3 & 2.8 & 3.0 \\
\hline Nontax revenue & 8.5 & 12.5 & 14.9 & 14.3 & 10.3 & 9.0 & 9.2 & 7.0 \\
\hline Property income & 1.7 & 1.1 & 2.4 & 2.6 & 1.4 & 1.7 & 1.5 & 0.3 \\
\hline Administrative fees & 0.5 & 2.8 & 3.2 & 4.8 & 1.7 & 1.5 & 0.6 & 0.8 \\
\hline Nonindustrial sales & 1.8 & 2.3 & 2.1 & 2.0 & 2.0 & 1.8 & 1.7 & 0.7 \\
\hline Other & 4.6 & 6.3 & 7.2 & 4.9 & 5.1 & 4.1 & 1.3 & 0.5 \\
\hline Oil revenue & 0.0 & 0.0 & 0.0 & 0.0 & 0.0 & 0.0 & 29.2 & 45.0 \\
\hline
\end{tabular}

Sources: Chadian authorities; and IMF staff estimates. 
Table 16. Chad: Economic Classification of Central Government Expenditure, 1998-2004

\begin{tabular}{|c|c|c|c|c|c|c|c|}
\hline & 1998 & 1999 & 2000 & 2001 & 2002 & 2003 & 2004 \\
\hline & \multicolumn{7}{|c|}{ (In billions of CFA francs) } \\
\hline Total expenditure & 153.3 & 178.8 & 203.2 & 220.3 & 277.9 & 345.3 & 333.6 \\
\hline Current expenditure & 75.0 & 87.9 & 99.9 & 109.8 & 137.6 & 146.7 & 151.5 \\
\hline Primary current expenditure & 66.5 & 79.2 & 89.6 & 100.7 & 125.6 & 137.2 & 141.4 \\
\hline Wages and salaries & 31.5 & 34.0 & 38.5 & 44.3 & 48.9 & 56.2 & 60.9 \\
\hline Goods and services & 16.1 & 18.5 & 20.8 & 22.6 & 24.2 & 36.2 & 24.7 \\
\hline Health & 2.7 & 3.1 & 4.2 & 5.2 & 4.9 & 7.3 & 4.4 \\
\hline Education & 2.5 & 3.0 & 4.0 & 4.6 & 5.7 & 4.7 & 1.0 \\
\hline Public works & 0.5 & 0.6 & 0.8 & 1.0 & 1.2 & 1.3 & 1.1 \\
\hline Social affairs & 0.4 & 0.5 & 0.6 & 0.7 & 1.0 & 1.1 & 0.7 \\
\hline Other & 10.0 & 11.3 & 11.2 & 11.1 & 11.4 & 21.7 & 17.6 \\
\hline Transfers & 8.6 & 13.8 & 13.5 & 6.9 & 18.9 & 16.5 & 26.9 \\
\hline International organizations & 0.3 & 1.2 & 1.1 & 0.7 & 1.5 & 0.9 & 1.4 \\
\hline Scholarships & 0.9 & 1.1 & 1.2 & 1.6 & 0.9 & 1.8 & 2.3 \\
\hline Pensions & 1.4 & 1.5 & 1.5 & $\ldots$ & $\ldots$ & $\ldots$ & $\ldots$ \\
\hline Subsidies & 2.5 & 2.7 & 7.1 & 3.5 & 10.3 & 6.1 & 8.2 \\
\hline Other & 3.4 & 7.3 & 2.6 & 1.0 & 6.2 & 7.7 & 15.0 \\
\hline Defense & 9.5 & 12.9 & 15.2 & 19.2 & 23.9 & 23.8 & 26.9 \\
\hline Salaries & 8.3 & 11.2 & 10.2 & 12.4 & 13.2 & 17.4 & 19.2 \\
\hline Materials and supplies & 1.2 & 1.7 & 5.0 & 6.8 & 10.7 & 6.4 & 7.6 \\
\hline Famine & 0.8 & 0.0 & 0.0 & 3.1 & 0.0 & 1.7 & 0.0 \\
\hline Elections & 0.0 & 0.1 & 0.4 & 4.7 & 2.0 & 0.0 & 2.0 \\
\hline Peace accord implementation & 0.0 & 0.0 & 1.3 & 0.0 & 2.5 & 2.9 & 0.0 \\
\hline Other primary current expenditure & 0.0 & 0.0 & 0.0 & 0.0 & 5.2 & 0.0 & 0.0 \\
\hline Interest & 8.4 & 8.7 & 10.3 & 9.1 & 12.0 & 9.5 & 10.2 \\
\hline Domestic & 1.3 & 1.1 & 1.4 & 0.6 & 1.3 & 0.9 & 1.9 \\
\hline External & 7.1 & 7.6 & 8.9 & 8.6 & 10.6 & 8.6 & 8.2 \\
\hline Investment expenditure & 78.4 & 90.9 & 103.3 & 110.5 & 140.3 & 198.6 & 182.1 \\
\hline Domestically financed & 5.0 & 8.8 & 10.7 & 11.4 & 16.9 & 28.9 & 48.7 \\
\hline Foreign financed & 73.3 & 82.1 & 92.6 & 99.1 & 123.5 & 169.7 & 133.4 \\
\hline Grants & 38.1 & 42.9 & 48.0 & 48.2 & 74.4 & 115.9 & 64.8 \\
\hline \multirow[t]{2}{*}{ Loans } & 35.3 & 39.2 & 44.6 & 50.8 & 49.0 & 53.7 & 68.6 \\
\hline & \multicolumn{7}{|c|}{ (In percent of total) } \\
\hline Total expenditure & 100.0 & 100.0 & 100.0 & 100.0 & 100.0 & 100.0 & 100.0 \\
\hline Current expenditure & 48.9 & 49.2 & 49.2 & 49.8 & 49.5 & 42.5 & 45.4 \\
\hline Primary current expenditure & 43.4 & 44.3 & 44.1 & 45.7 & 45.2 & 39.7 & 42.4 \\
\hline Wages and salaries & 20.6 & 19.0 & 19.0 & 20.1 & 17.6 & 16.3 & 18.3 \\
\hline Goods and services & 10.5 & 10.3 & 10.2 & 10.2 & 8.7 & 10.5 & 7.4 \\
\hline Transfers & 5.6 & 7.7 & 6.6 & 3.1 & 6.8 & 4.8 & 8.1 \\
\hline Defense & 6.2 & 7.2 & 7.5 & 8.7 & 8.6 & 6.9 & 8.1 \\
\hline Famine & 0.5 & 0.0 & 0.0 & 1.4 & 0.0 & 0.5 & 0.0 \\
\hline Elections & 0.0 & 0.1 & 0.2 & 2.1 & 0.7 & 0.0 & 0.6 \\
\hline Peace accord implementation & 0.0 & 0.0 & 0.6 & 0.0 & 0.9 & 0.8 & 0.0 \\
\hline Other current expenditure & 0.0 & 0.0 & 0.0 & 0.0 & 1.9 & 0.0 & 0.0 \\
\hline Interest & 5.5 & 4.8 & 5.1 & 4.1 & 4.3 & 2.8 & 3.0 \\
\hline Domestic & 0.9 & 0.6 & 0.7 & 0.3 & 0.5 & 0.3 & 0.6 \\
\hline External & 4.6 & 4.2 & 4.4 & 3.9 & 3.8 & 2.5 & 2.5 \\
\hline Investment expenditure & 51.1 & 50.8 & 50.8 & 50.2 & 50.5 & 57.5 & 54.6 \\
\hline Domestically financed & 3.3 & 4.9 & 5.3 & 5.2 & 6.1 & 8.4 & 14.6 \\
\hline Foreign financed & 47.8 & 45.9 & 45.5 & 45.0 & 44.4 & 49.1 & 40.0 \\
\hline Grants & 24.8 & 24.0 & 23.6 & 21.9 & 26.8 & 33.6 & 19.4 \\
\hline Loans & 23.0 & 21.9 & 21.9 & 23.1 & 17.6 & 15.6 & 20.6 \\
\hline
\end{tabular}

Sources: Chadian authorities; and IMF staff estimates. 


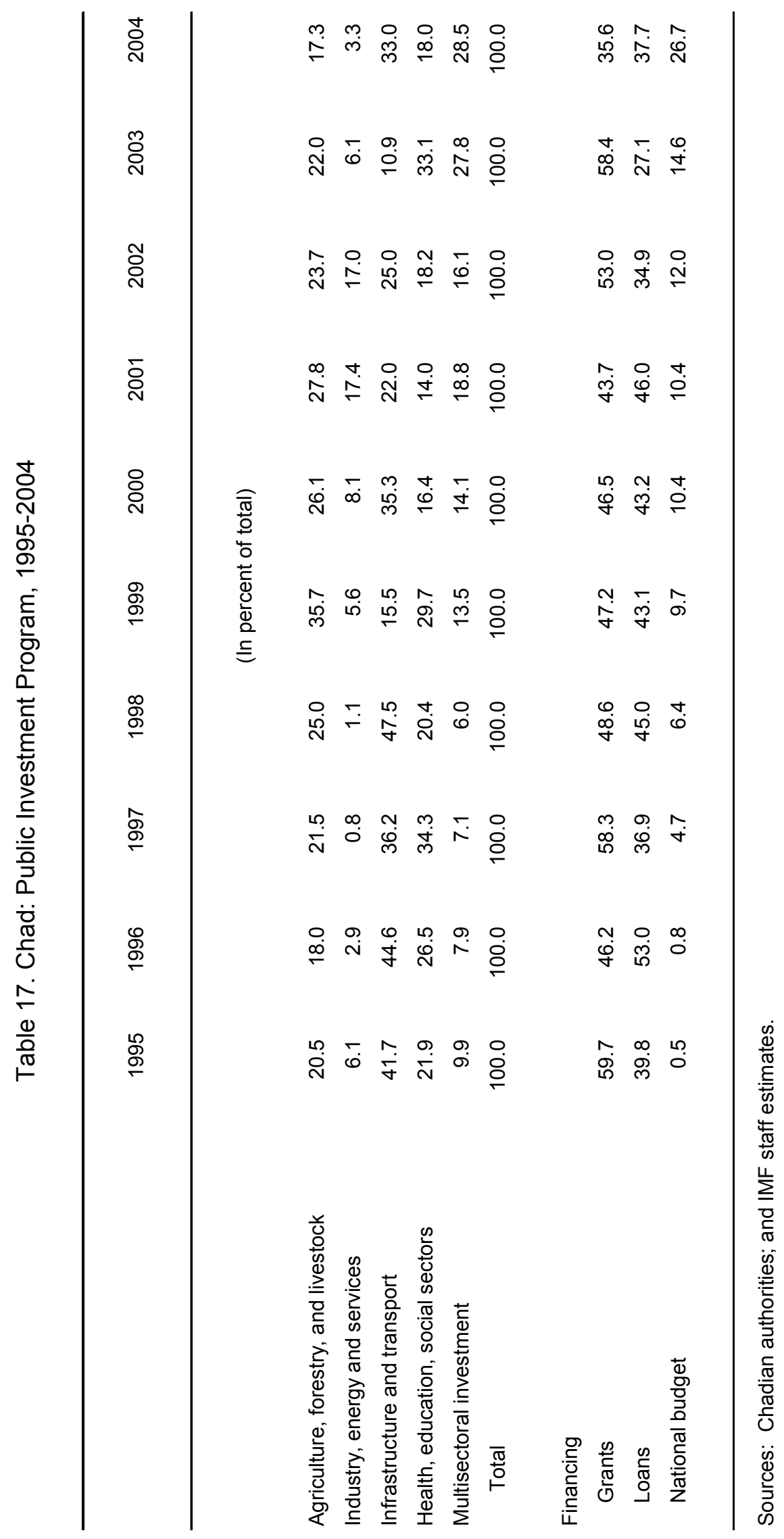


Table 18. Chad: Central Government Employment, 1995-2004

(In number of staff)

\begin{tabular}{|c|c|c|c|c|c|c|c|c|c|c|}
\hline & 1995 & 1996 & 1997 & 1998 & 1999 & 2000 & 2001 & 2002 & 2003 & 2004 \\
\hline Presidency & 1,311 & 828 & 1,087 & 1,104 & 1,327 & 1,643 & 1,665 & 1,827 & 2,067 & 1,122 \\
\hline Services linked to the presidency & 346 & 369 & 9 & $\ldots$ & 202 & 240 & $\ldots$ & $\ldots$ & $\ldots$ & $\ldots$ \\
\hline Office of the Prime Minister & $\ldots$ & $\ldots$ & 302 & 287 & 98 & 126 & 145 & 282 & 435 & 277 \\
\hline National Advisory Council (CST) & 106 & 125 & $\ldots$ & $\ldots$ & $\ldots$ & $\ldots$ & $\ldots$ & $\ldots$ & $\ldots$ & $\ldots$ \\
\hline Parliament & $\ldots$ & $\ldots$ & 204 & 226 & 224 & 230 & 231 & 278 & 334 & 356 \\
\hline Planning and Cooperation & 203 & 209 & 205 & 202 & 186 & 188 & 196 & 194 & 183 & 175 \\
\hline Information and Culture & 412 & 300 & 370 & 355 & 377 & 371 & 396 & 402 & 404 & 453 \\
\hline Foreign Affairs & 467 & 483 & 356 & 451 & 425 & 441 & 454 & 455 & 462 & 477 \\
\hline Finance and Computer Services & 1,919 & 2,027 & 2,008 & 2,048 & 2,057 & 2,079 & 2,346 & 2,550 & 2,520 & 2,846 \\
\hline Civil Service & 173 & 246 & 186 & 185 & 173 & 169 & 172 & 174 & 164 & 156 \\
\hline Justice & 916 & 913 & 876 & 866 & 995 & 1,056 & 1,065 & 1,207 & 1,320 & 1,467 \\
\hline Interior & 4,673 & 5,318 & 6,264 & 6,326 & 6,638 & 6,741 & 6,587 & 7,437 & 4,915 & 5,815 \\
\hline Education & 9,032 & 8,925 & 8,910 & 9,084 & 9,572 & 10,161 & 11,259 & 11,591 & 12,799 & 13,665 \\
\hline Health & 2,881 & 2,824 & 2,867 & 2,817 & 2,881 & 2,894 & 2,917 & 3,145 & 3,446 & 3,707 \\
\hline Women's Conditions and Social Affairs & 526 & 512 & 523 & 518 & 499 & 583 & 618 & 644 & 670 & 757 \\
\hline Agriculture & 2,299 & 1,295 & 1,172 & 1,140 & 1,137 & 1,311 & 1,257 & 1,223 & 1,143 & 1,189 \\
\hline Livestock & 891 & 770 & 753 & 751 & 707 & 702 & 709 & 731 & 759 & 716 \\
\hline Tourism & 1 & 0 & 6 & 33 & 36 & 34 & 35 & 37 & 44 & 44 \\
\hline Commerce and Industry & 272 & 242 & 223 & 220 & 207 & 205 & 210 & 204 & 210 & 206 \\
\hline Mines and Energy & 217 & 284 & 447 & 122 & 133 & 141 & 146 & 149 & 111 & 103 \\
\hline Public Works & 359 & 387 & 340 & 344 & 362 & 366 & 346 & 361 & 262 & 271 \\
\hline Post and Telecommunications & 73 & 44 & 43 & 45 & 33 & 39 & 34 & 34 & 76 & 37 \\
\hline Other $1 /$ & 0 & 1,240 & 1,446 & 1,764 & 90 & 91 & 1,379 & 1,394 & 4,993 & 5,211 \\
\hline Total civil servants & 27,077 & 27,341 & 28,597 & 28,888 & 28,359 & 29,811 & 32,167 & 34,319 & 37,317 & 39,050 \\
\hline National Defense 2/ & 489 & 1,108 & 1,208 & $\ldots$ & $\ldots$ & $\ldots$ & 25,000 & 25,000 & 25,000 & 26,750 \\
\hline Total & 27,566 & 28,449 & 29,805 & 28,888 & 28,359 & 29,811 & 57,167 & 59,319 & 62,317 & 65,800 \\
\hline
\end{tabular}

Sources: Chadian authorities; and IMF staff estimates.

1/ Includes mainly the following ministries: Youth and Sports; Environment and Water; Superior Education; and Public Security, this latter created in 2003.

2/ For 1995 and 1996, including the Prime Minister's Office. 
Table 19. Chad: Monetary Survey, 1998-2005

\begin{tabular}{|c|c|c|c|c|c|c|c|c|}
\hline & 1998 & 1999 & 2000 & 2001 & 2002 & 2003 & 2004 & 2005 \\
\hline & \multicolumn{8}{|c|}{ (In billions of CFA francs) } \\
\hline Net foreign assets & 42.7 & 37.4 & 35.9 & 27.8 & 81.3 & 50.3 & 61.3 & 86.6 \\
\hline Central bank & 33.9 & 18.8 & 22.2 & 25.5 & 71.6 & 43.7 & 62.4 & 83.9 \\
\hline Commercial banks & 8.8 & 18.6 & 13.7 & 2.3 & 9.7 & 6.6 & -1.1 & 2.6 \\
\hline Medium- and long-term foreign liabilities & 0.0 & -2.0 & -2.3 & -1.9 & -2.4 & -4.3 & -5.5 & -7.7 \\
\hline Net domestic assets & 62.8 & 68.9 & 89.7 & 125.6 & 109.3 & 136.3 & 132.4 & 252.9 \\
\hline Domestic credit & 90.5 & 107.2 & 127.8 & 157.1 & 155.3 & 185.3 & 176.3 & 215.5 \\
\hline Claims on government (net) & 36.2 & 48.2 & 61.9 & 77.4 & 76.1 & 87.2 & 83.4 & 85.9 \\
\hline Treasury (net) & 48.9 & 60.4 & 71.4 & 87.4 & 84.0 & 96.6 & 94.3 & 119.8 \\
\hline Other (nontreasury) & -12.8 & -12.2 & -9.6 & -10.1 & -7.9 & -9.3 & -10.9 & -33.9 \\
\hline Credit to the economy & 54.3 & 59.1 & 65.9 & 79.8 & 79.1 & 98.1 & 92.9 & 129.6 \\
\hline Other items (net) & -27.7 & -38.4 & -38.0 & -31.5 & -46.0 & -49.1 & -43.8 & 37.4 \\
\hline Money and quasi money (M2) & 105.5 & 104.3 & 123.3 & 147.6 & 188.2 & 182.3 & 188.3 & 480.9 \\
\hline Currency outside banks & 73.6 & 68.2 & 80.7 & 93.9 & 116.8 & 110.9 & 109.7 & 248.4 \\
\hline Demand deposits & 26.1 & 29.8 & 34.3 & 43.4 & 59.8 & 60.2 & 65.3 & 154.8 \\
\hline Quasi money & 5.8 & 6.3 & 8.3 & 10.2 & 11.6 & 11.2 & 13.3 & 77.7 \\
\hline \multicolumn{9}{|c|}{ (Changes in percent of beginning of period money stock, unless otherwise indicated) } \\
\hline Net foreign assets & -11.6 & -5.0 & -1.5 & -6.6 & 36.2 & -16.5 & 6.0 & 13.4 \\
\hline Net domestic assets & 3.3 & 5.7 & 20.0 & 29.1 & -11.0 & 14.3 & -2.1 & 64.0 \\
\hline Domestic credit & -0.7 & 15.8 & 19.7 & 23.8 & -1.3 & 16.0 & -5.0 & 20.8 \\
\hline Claims on government (net) & -4.3 & 11.4 & 13.1 & 12.6 & -0.9 & 5.9 & -2.1 & 1.3 \\
\hline Of which: treasury (net) & 1.7 & 10.8 & 10.6 & 13.0 & -2.4 & 6.7 & -1.2 & 13.5 \\
\hline Claims on the private sector & 3.6 & 4.5 & 6.6 & 11.2 & -0.4 & 10.1 & -2.9 & 19.5 \\
\hline Money and quasi money (M2) & 7.6 & -1.2 & 18.3 & 19.6 & 27.5 & -3.1 & 3.3 & 155.5 \\
\hline Currency outside banks & 4.7 & -5.2 & 12.0 & 10.7 & 15.5 & -3.1 & -0.7 & 73.7 \\
\hline Demand deposits & 2.4 & 3.4 & 4.4 & 7.4 & 11.1 & 0.2 & 2.8 & 47.5 \\
\hline Quasi money & 0.4 & 0.5 & 1.9 & 1.6 & 0.9 & -0.2 & 1.2 & 34.2 \\
\hline \multicolumn{9}{|l|}{ Memorandum items: } \\
\hline \multicolumn{9}{|l|}{ Currency outside banks } \\
\hline As a percentage of broad money & 69.8 & 65.4 & 65.4 & 63.6 & 62.1 & 60.8 & 58.2 & 51.7 \\
\hline As a percentage of deposits & 281.6 & 229.1 & 234.9 & 216.3 & 195.3 & 184.1 & 167.9 & 160.5 \\
\hline Money velocity (non-oil GDP relative to $\mathrm{M} 2$ ) & 9.7 & 9.0 & 8.6 & 9.1 & 7.1 & 7.5 & 7.3 & 1.4 \\
\hline
\end{tabular}


Table 20. Chad: Summary Accounts of the Central Bank, 1998-2004

(In billions of CFA francs; or, unless otherwise indicated; end of period)

\begin{tabular}{|c|c|c|c|c|c|c|c|}
\hline & 1998 & 1999 & 2000 & 2001 & 2002 & 2003 & 2004 \\
\hline Foreign assets & 69.4 & 64.4 & 80.2 & 93.5 & 139.1 & 99.6 & 109.1 \\
\hline Gold & 1.8 & 2.1 & 2.1 & 2.3 & 2.4 & 2.4 & 2.4 \\
\hline Billets CFAF zone & & & & & 0.4 & 0.6 & 0.5 \\
\hline Foreign exchange & 67.3 & 61.8 & 77.8 & 90.8 & 136.1 & 96.4 & 106.0 \\
\hline IMF & 0.3 & 0.3 & 0.3 & 0.3 & 0.2 & 0.2 & 0.2 \\
\hline SDRs & 0.1 & 0.2 & 0.0 & 0.0 & 0.0 & 0.0 & 0.0 \\
\hline Reserve position & 0.2 & 0.3 & 0.3 & 0.3 & 0.2 & 0.2 & 0.2 \\
\hline Claims on government & 64.8 & 73.9 & 89.8 & 102.5 & 106.8 & 103.5 & 105.7 \\
\hline Direct advances 1/ & 10.9 & 10.9 & 16.6 & 18.1 & 21.7 & 30.9 & 42.0 \\
\hline Rehabiliation of the banking sector $2 /$ & 18.2 & 18.2 & 18.2 & 18.15 & 18.15 & 17.6 & 17.6 \\
\hline Counterpart of IMF purchases & 35.7 & 44.9 & 55.1 & 66.2 & 66.9 & 55.0 & 46.1 \\
\hline Claims on commercial banks & 14.6 & 7.3 & 4.5 & 7.5 & 1.5 & 10.4 & 7.8 \\
\hline Others & -3.7 & -4.9 & 1.0 & 3.9 & 0.0 & 0.0 & 0.0 \\
\hline Total assets $=$ total liabilities & 145.1 & 140.7 & 175.5 & 207.3 & 247.3 & 213.5 & 222.6 \\
\hline Reserve money & 84.5 & 79.2 & 92.1 & 107.7 & 145.4 & 130.4 & 140.0 \\
\hline Currency outside banks & 73.6 & 68.2 & 81.3 & 94.3 & 116.8 & 110.9 & 110.1 \\
\hline Bank reserves & 10.1 & 10.4 & 9.9 & 12.9 & 28.6 & 19.5 & 29.9 \\
\hline Other reserves & 0.8 & 0.6 & 1.0 & 0.5 & 0.0 & 0.0 & 0.0 \\
\hline Short-term foreign liabilities & 35.4 & 45.4 & 58.0 & 67.9 & 67.4 & 55.9 & 46.7 \\
\hline Of which: use of Fund credit (net) & 35.7 & 44.9 & 55.1 & 66.2 & 66.9 & 55.0 & 46.1 \\
\hline Government deposits & 9.9 & 3.3 & 6.2 & 10.3 & 13.6 & 6.2 & 17.8 \\
\hline Of which: treasury & 2.3 & 2.8 & 3.7 & 4.2 & 5.5 & 5.7 & 8.5 \\
\hline Other items & 15.3 & 12.6 & 19.2 & 21.4 & 21.1 & 21 & 18.1 \\
\hline
\end{tabular}

Sources: Bank of Central African States (BEAC); and IMF staff estimates.

$1 /$ Includes short- and medium-term advances to the treasury, as well as compulsory withdrawals.

2/ Consolidation of the BEAC rediscounts to commercial banks into claims on the government. 
Table 21. Chad: Balance Sheet of Commercial Banks, 1998-2004

(In billions of CFA francs; or unless otherwise indicated)

\begin{tabular}{|c|c|c|c|c|c|c|c|c|}
\hline & 1996 & 1998 & 1999 & 2000 & 2001 & 2002 & 2003 & 2004 \\
\hline Reserves 1/ & 7.4 & 10.1 & 10.4 & 9.9 & 12.9 & 28.6 & 19.5 & 29.9 \\
\hline Foreign assets & 5.5 & 13.6 & 25.9 & 19.5 & 13.0 & 25.8 & 20 & 19 \\
\hline Claims on government 2/ & 2.2 & 1.9 & 1.6 & 2.5 & 7.4 & 8.8 & 12.5 & 23.7 \\
\hline Claims on private sector & 47.6 & 54.3 & 49.2 & 54.4 & 65.4 & 79.1 & 98.1 & 92.9 \\
\hline Other items & $\ldots$ & 1.2 & 10.0 & 17.5 & 25.1 & 31.6 & $\ldots$ & $\ldots$ \\
\hline Total assets $=$ total liabilities & 62.7 & 81.2 & 97.1 & 103.8 & 123.8 & 173.9 & 150.1 & 165.5 \\
\hline Demand deposits & 22.6 & 25.4 & 27.8 & 31.6 & 43.4 & 59.8 & 60.2 & 65.3 \\
\hline Time deposits & 5.4 & 5.8 & 6.1 & 8.0 & 9.9 & 11.6 & 11.2 & 13.3 \\
\hline Short-term foreign liabilities & 4.6 & 4.8 & 7.5 & 6.9 & 9.7 & 16.1 & 13.4 & 20.1 \\
\hline Long-term foreign liabilities & 0.0 & 0.0 & 2.0 & 2.3 & 1.9 & 2.4 & 4.3 & 5.5 \\
\hline Government deposits 2/ & 13.3 & 21.4 & 23.7 & 22.8 & 20.2 & 29.6 & 25.5 & 27.7 \\
\hline Credit from the central bank & 7.7 & 10.7 & 4.1 & 0.5 & 4.5 & 1.5 & 10.4 & 7.8 \\
\hline Other items & $\cdots$ & 13.2 & 25.9 & 31.8 & 34.2 & 52.9 & 25.2 & 25.7 \\
\hline \multicolumn{9}{|l|}{ Memorandum item: } \\
\hline Bank reserves as a percentage of deposits & 26.5 & 32.5 & 30.5 & 25.0 & 24.2 & 40.0 & 27.3 & 38.0 \\
\hline
\end{tabular}

Sources: Bank of Central African States (BEAC ); and IMF staff estimates.

$1 /$ Includes cash and bank deposits at the BEAC.

2/ Government inludes the treasury and other public agencies. 
Table 22. Chad: Net Claims of the Banking System on Government, 1998-2004 (In billions of CFA francs; or, unless otherwise indicated; end of period)

\begin{tabular}{|c|c|c|c|c|c|c|c|}
\hline & 1998 & 1999 & 2000 & 2001 & 2002 & 2003 & 2004 \\
\hline Banking system's net claims on the treasury & 43.7 & 52.2 & 70.9 & 86.9 & 79.7 & 84.3 & 83.9 \\
\hline Claims & 65.6 & 74.5 & 91.1 & 105.2 & 111.1 & 116.0 & 129.4 \\
\hline Liabilities & 22.0 & 22.3 & 20.2 & 18.3 & 31.4 & 31.7 & 45.5 \\
\hline Central bank (net) & 55.0 & 70.7 & 83.6 & 92.2 & 93.2 & 97.3 & 87.9 \\
\hline Claims on central government & 64.8 & 73.9 & 89.8 & 102.5 & 106.8 & 103.5 & 105.7 \\
\hline Direct advances & 10.9 & 10.9 & 16.6 & 18.1 & 21.7 & 30.9 & 42.0 \\
\hline Advances on current account & 10.9 & 10.9 & 16.6 & 18.1 & 21.7 & 30.9 & 42.0 \\
\hline Compulsory withdrawal & 0.0 & 0.0 & 0.0 & 0.0 & 0.0 & 0.0 & 0.0 \\
\hline Medium-term advances & 0.0 & 0.0 & 0.0 & 0.0 & 0.0 & 0.0 & 0.0 \\
\hline Counterpart of use of IMF resources & 35.7 & 44.9 & 55.1 & 66.2 & 66.9 & 55.0 & 46.1 \\
\hline Rehabilitation of the banking system & 18.2 & 18.2 & 18.2 & 18.2 & 18.2 & 17.6 & 17.6 \\
\hline Liabilities & 9.9 & 3.3 & 6.2 & 10.3 & 13.6 & 6.2 & 17.8 \\
\hline Deposits & 7.6 & 0.5 & 2.5 & 6.1 & 8.0 & 0.5 & 9.3 \\
\hline Currency held by Treasury & 2.3 & 2.8 & 3.7 & 4.2 & 5.5 & 5.7 & 8.5 \\
\hline Commercial banks (net) & -11.3 & -18.5 & -12.7 & -5.2 & -13.4 & -13.0 & -4.0 \\
\hline Claims $1 /$ & 0.8 & 0.5 & 1.3 & 2.7 & 4.3 & 12.5 & 23.7 \\
\hline Liabilities & 12.1 & 19.0 & 14.0 & 8.0 & 17.8 & 25.5 & 27.7 \\
\hline Banking system's net claims on government & 36.2 & 48.2 & 61.9 & 77.4 & 76.1 & 87.2 & 83.4 \\
\hline
\end{tabular}

Sources: Bank of Central African States (BEAC ); and IMF staff estimates.

$1 /$ Including the postal checking system. 


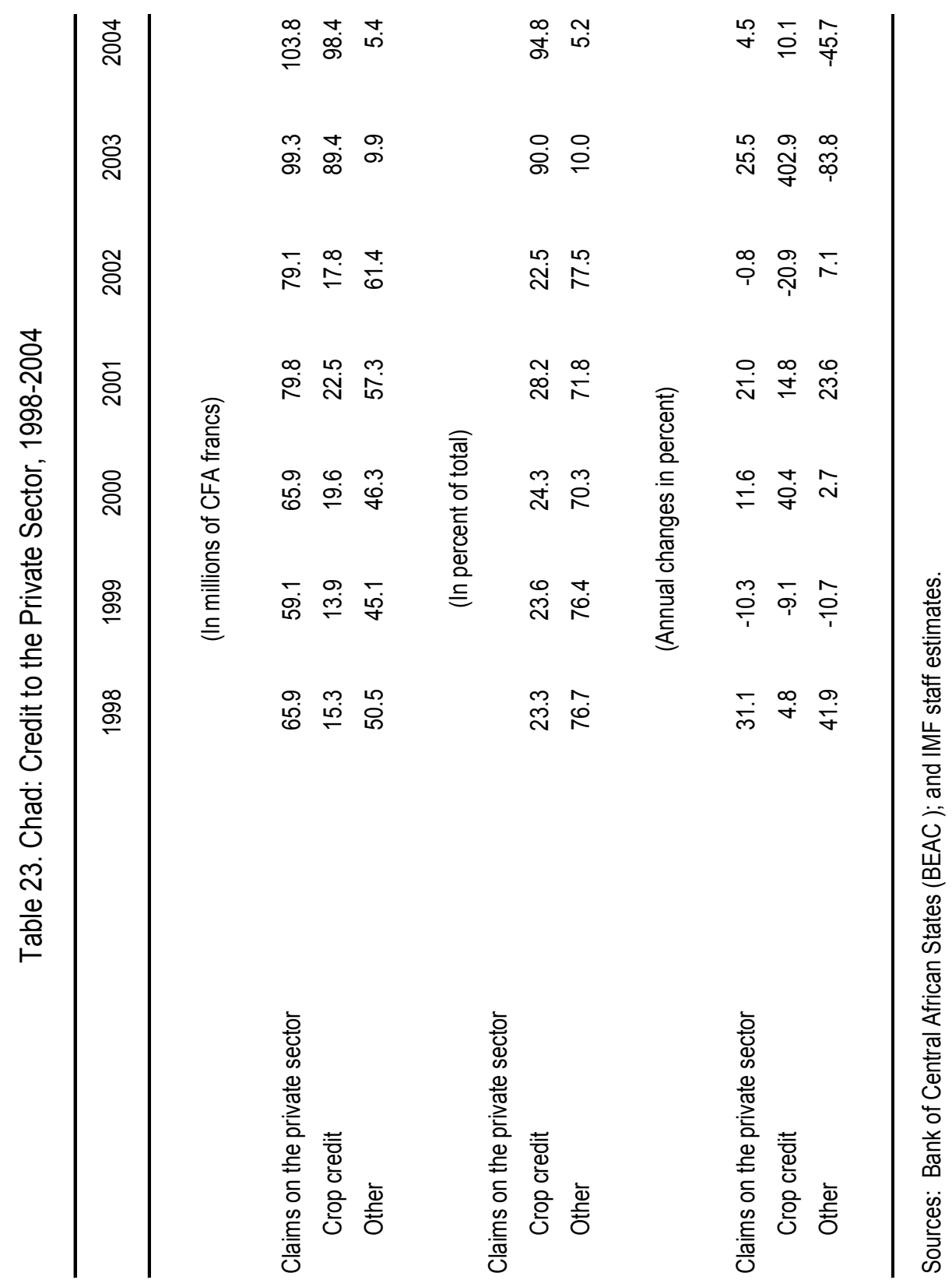




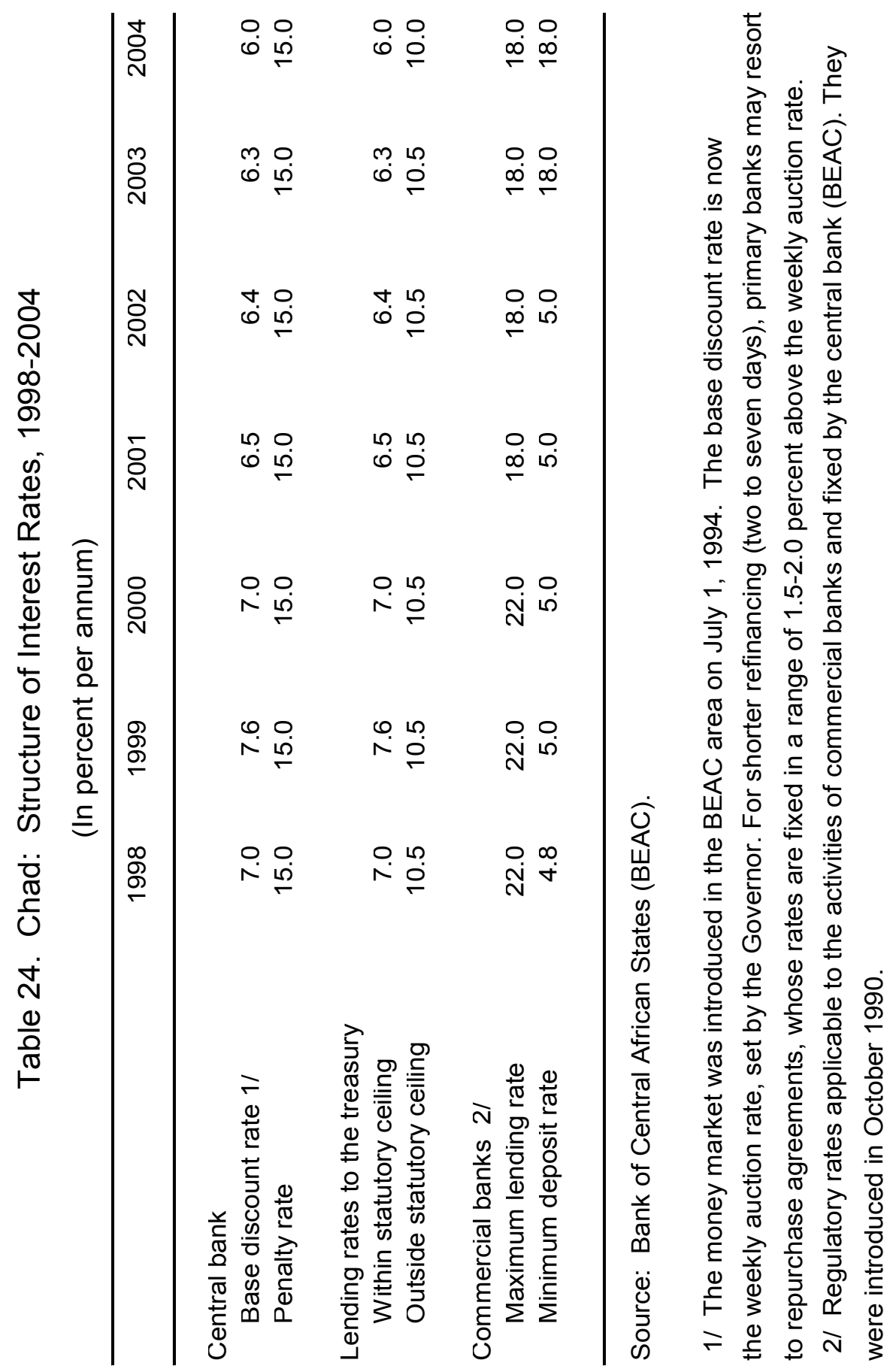


Table 25. Chad: Balance of Payments, 1998-2005

\begin{tabular}{|c|c|c|c|c|c|c|c|c|}
\hline & 1998 & 1999 & 2000 & 2001 & 2002 & 2003 & 2004 & 2005 \\
\hline & \multicolumn{8}{|c|}{ (In billions of CFA francs) } \\
\hline Goods and services balance & -114.0 & -131.1 & -175.4 & -438.4 & -1398.8 & -542.6 & 5.8 & 474.9 \\
\hline Trade balance (including oil sector) & -11.5 & -22.1 & -40.2 & -239.4 & -978.4 & -102.8 & 679.8 & 1211.1 \\
\hline Exports,f.o.b & 154.3 & 140.2 & 130.2 & 138.4 & 128.9 & 350.4 & 1142.1 & 1639.2 \\
\hline Of which: oil & 0.0 & 0.0 & 0.0 & 0.0 & 0.0 & 136.8 & 936.3 & 1415.0 \\
\hline Imports, f.o.b. & -165.8 & -162.3 & -170.4 & -377.8 & -1107.3 & -453.2 & -462.3 & -428.1 \\
\hline Of which: oil \& related & -30.8 & -50.7 & -59.8 & -234.0 & -909.9 & -209.0 & -108.2 & -128.0 \\
\hline Services (including oil sector) & -102.5 & -109.0 & -135.2 & -199.0 & -420.4 & -439.8 & -674.0 & -736.2 \\
\hline Credit & 36.0 & 32.9 & 36.4 & 45.4 & 46.9 & 41.4 & 47.6 & 66.4 \\
\hline Debit & -138.6 & -141.9 & -171.6 & -244.4 & -467.3 & -481.2 & -721.6 & -802.6 \\
\hline Ut which: oil & 0.0 & 0.0 & 0.0 & -64.4 & -263.8 & -280.2 & -466.8 & -600.4 \\
\hline Income & -0.4 & -1.0 & -12.4 & -16.5 & -41.5 & -265.3 & -231.5 & -543.2 \\
\hline Of which: oil & 0.0 & 0.0 & 0.0 & 0.0 & -31.1 & -252.9 & -201.3 & -484.5 \\
\hline Current transfers & 30.5 & 25.6 & 36.0 & 32.8 & 49.8 & 57.6 & 114.8 & 94.8 \\
\hline General government (net) & 16.5 & 20.1 & 31.4 & 18.4 & 26.9 & 43.0 & 72.9 & 62.3 \\
\hline Other sectors (net) & 14.0 & 5.5 & 4.6 & 14.4 & 22.9 & 14.6 & 41.9 & 32.5 \\
\hline Current account balance (including official transfers) & -83.9 & -106.5 & -151.8 & -422.1 & -1390.5 & -750.3 & -110.9 & 26.5 \\
\hline Current account balance (including oil, excluding official transfers & -100.4 & -126.6 & -183.2 & -440.5 & -1417.4 & -793.3 & -183.8 & -35.8 \\
\hline Current account balance (excluding oil, including official transfers & -53.1 & -55.8 & -92.0 & -123.7 & -185.7 & -145.0 & -271.0 & -175.6 \\
\hline Capital and financial account & 47.5 & 85.0 & 148.2 & 407.4 & 1373.8 & 420.1 & 162.2 & 61.4 \\
\hline Long- and medium-term capital & 64.1 & 81.1 & 155.4 & 491.3 & 752.7 & 540.8 & 390.6 & 420.6 \\
\hline Public & 57.7 & 69.1 & 61.9 & 166.0 & 127.0 & 149.0 & 165.3 & 137.7 \\
\hline Grants & 26.6 & 19.7 & 33.9 & 34.8 & 59.0 & 81.1 & 95.9 & 91.1 \\
\hline Loans & 31.1 & 49.4 & 28.0 & 131.2 & 68.0 & 67.9 & 69.4 & 46.7 \\
\hline Drawing & 47.4 & 64.7 & 42.9 & 80.4 & 89.9 & 81.1 & 81.3 & 58.1 \\
\hline Amortization & -16.3 & -15.3 & -14.9 & 50.8 & -21.9 & -13.2 & -11.8 & -11.4 \\
\hline Private & 6.4 & 12.0 & 93.5 & 325.3 & 625.7 & 391.8 & 225.3 & 282.9 \\
\hline Direct investment & 6.1 & 9.6 & 82.0 & 319.8 & 643.9 & 414.0 & 252.6 & 323.8 \\
\hline Ot which: oil related & 0.0 & 0.0 & 54.5 & 287.8 & 633.8 & 599.9 & 252.6 & 303.8 \\
\hline Other investments & 0.3 & 2.4 & 11.5 & 5.5 & -18.2 & -22.2 & -27.3 & -40.9 \\
\hline Fund for Future Generations & $\ldots$ & $\ldots$ & $\ldots$ & $\ldots$ & $\ldots$ & $\ldots$ & 5.0 & 13.0 \\
\hline Short-term capital (net) & -16.6 & 3.9 & -7.2 & -83.9 & 621.1 & -120.7 & -233.4 & -372.2 \\
\hline Errors and omissions (net) & 23.0 & 6.4 & 4.8 & 6.7 & 53.1 & 303.5 & -33.8 & -64.5 \\
\hline Overall balance & -13.4 & -15.2 & 1.1 & -8.0 & 36.3 & -26.7 & 17.5 & 23.5 \\
\hline Financing & 13.4 & 15.2 & -1.1 & 8.0 & -36.3 & 26.7 & -17.5 & -23.5 \\
\hline Change in official net reserves & 11.5 & 15.2 & -3.4 & -3.3 & -46.1 & 27.9 & -18.7 & -21.5 \\
\hline of which: Use of IMF resources (net) & 0.0 & 4.1 & 6.4 & 9.4 & 7.0 & -6.4 & -7.1 & -3.8 \\
\hline Change in arrears & -1.6 & 0.0 & 2.3 & 0.7 & 5.1 & -2.3 & 1.3 & -2.5 \\
\hline Rescheduling of public debt and arrears & 3.5 & 0.0 & 0.0 & 10.6 & 4.6 & 1.1 & 0.0 & 0.5 \\
\hline Memorandum items: & \multicolumn{8}{|c|}{ (In percent, unless otherwise indicated) } \\
\hline Nominal GDP (in billions of CFA francs) & $1,029.3$ & 944.9 & 986.1 & $1,253.0$ & $1,385.3$ & $1,582.4$ & $2,332.2$ & $3,111.2$ \\
\hline Current account balance (incl official transfers)/GDP & -8.1 & -11.3 & -15.4 & -33.7 & -100.4 & -47.4 & -4.8 & 0.9 \\
\hline Current account balance (incl oil, excl official transfers)/GDP & -9.8 & -13.4 & -18.6 & -35.2 & -102.3 & -50.1 & -7.9 & -1.2 \\
\hline Current account balance (excl oil, incl official transfers)/GDP & -5.2 & -5.9 & -9.3 & -9.9 & -13.4 & -9.2 & -11.6 & -5.6 \\
\hline Gross official reserves (in billions of CFA francs) & 69.3 & 64.2 & 80.2 & 93.4 & 138.9 & 99.6 & 111.2 & 128.9 \\
\hline $\begin{array}{l}\text { Gross official reserves (in months of imports goods } \\
\text { and nontactor services, excludıng oll sector) }\end{array}$ & 2.7 & 2.5 & 2.8 & 1.8 & 1.1 & 1.3 & 1.1 & 1.3 \\
\hline External debt outstanding (in billions of CFA francs) $1 /$ & 558.4 & 619.8 & 731.8 & 721.9 & 732.8 & 731.3 & 756.6 & 880.7 \\
\hline Debt outstanding /GDP 1/ & 54.2 & 65.6 & 74.2 & 57.6 & 52.9 & 46.2 & 32.4 & 28.3 \\
\hline Debt service (in billions of CFA francs) $1 /$ & 28.7 & 66.0 & 44.6 & 50.8 & 26.7 & 17.3 & 18.1 & 3.8 \\
\hline Debt service/exports of goods and nonfactor services $1 /$ & 15.1 & 38.1 & 26.8 & 27.6 & 15.2 & 4.4 & 1.5 & 0.2 \\
\hline
\end{tabular}

Sources: Chadian authorities; and IMF staff estimates.

1/ After HIPC Initiative interim assistance. 
Table 26. Chad: External Financial Assistance, 1998-2005

\begin{tabular}{|c|c|c|c|c|c|c|c|c|}
\hline & 1998 & 1999 & 2000 & 2001 & 2002 & 2003 & 2004 & 2005 \\
\hline & \multicolumn{8}{|c|}{ (In billions of CFA francs) } \\
\hline Total grants & 33.1 & 38.4 & 55.6 & 19.9 & 35.9 & 71.4 & 127.5 & 103.4 \\
\hline Current grants & 16.5 & 20.1 & 31.4 & 18.4 & 26.9 & 43.0 & 72.9 & 62.3 \\
\hline Budgetary & 0.0 & 1.8 & 7.2 & 15.5 & 10.5 & 6.8 & 13.1 & 13.1 \\
\hline HIPC Initiative assistance & 0.0 & 0.0 & 0.0 & 1.3 & 7.4 & 7.8 & 5.1 & 8.1 \\
\hline Capital grants & 16.5 & 18.3 & 24.2 & 1.5 & 9.0 & 28.4 & 54.6 & 41.1 \\
\hline Net drawings & 14.8 & 34.1 & 13.1 & 182.1 & 46.0 & 54.7 & 57.6 & 35.3 \\
\hline Gross drawings & 31.1 & 49.4 & 28.0 & 131.2 & 68.0 & 67.9 & 69.4 & 46.7 \\
\hline Project loans & 47.4 & 64.7 & 42.9 & 80.4 & 89.9 & 81.1 & 81.3 & 58.1 \\
\hline Program loans & 0.0 & 25.5 & 0.0 & 0.0 & 40.9 & 27.3 & 12.7 & 0.0 \\
\hline Amortization & -16.3 & -15.3 & -14.9 & 50.8 & -21.9 & -13.2 & -11.8 & -11.4 \\
\hline Use of IMF resources (net) & 0.0 & 4.1 & 6.4 & 9.4 & 7.0 & -6.4 & -7.1 & -3.8 \\
\hline Net repayments of arrears (- reduction) & -1.6 & 0.0 & 2.3 & 0.7 & 5.1 & -2.3 & 1.3 & -2.5 \\
\hline Debt relief & 3.5 & 0.0 & 0.0 & 10.6 & 4.6 & 1.1 & 0.0 & 0.5 \\
\hline \multirow[t]{2}{*}{ Total net foreign assistance } & 49.8 & 76.6 & 77.4 & 222.7 & 98.7 & 118.4 & 179.2 & 132.9 \\
\hline & \multicolumn{8}{|c|}{ (In percent of GDP) } \\
\hline Total grants & 3.2 & 4.1 & 5.6 & 1.6 & 2.6 & 4.5 & 5.5 & 3.3 \\
\hline Current grants & 1.6 & 2.1 & 3.2 & 1.5 & 1.9 & 2.7 & 3.1 & 2.0 \\
\hline Budgetary & 0.0 & 0.2 & 0.7 & 1.2 & 0.8 & 0.4 & 0.6 & 0.4 \\
\hline HIPC assistance & 0.0 & 0.0 & 0.0 & 0.1 & 0.5 & 0.5 & 0.2 & \\
\hline Capital grants & 1.6 & 1.9 & 2.5 & 0.1 & 0.7 & 1.8 & 2.3 & 1.3 \\
\hline Net drawings & 1.4 & 3.6 & 1.3 & 14.5 & 3.3 & 3.5 & 2.5 & 1.1 \\
\hline Gross drawings & 3.0 & 5.2 & 2.8 & 10.5 & 4.9 & 4.3 & 3.0 & 1.5 \\
\hline Project loans & 4.6 & 6.8 & 4.4 & 6.4 & 6.5 & 5.1 & 3.5 & 1.9 \\
\hline Program loans & 0.0 & 2.7 & 0.0 & 0.0 & 2.9 & 1.7 & 0.5 & 0.0 \\
\hline Amortization & -1.6 & -1.6 & -1.5 & 4.1 & -1.6 & -0.8 & -0.5 & -0.4 \\
\hline Use of IMF resources (net) & 0.0 & 0.4 & 0.6 & 0.8 & 0.5 & -0.4 & -0.3 & -0.1 \\
\hline Net repayments of arrears (- reduction) & -0.2 & 0.0 & 0.2 & 0.1 & 0.4 & -0.1 & 0.1 & -0.1 \\
\hline Debt relief & 0.3 & 0.0 & 0.0 & 0.8 & 0.3 & 0.1 & 0.0 & 0.0 \\
\hline Total net foreign assistance & 4.8 & 8.1 & 7.8 & 17.8 & 7.1 & 7.5 & 7.7 & 4.3 \\
\hline
\end{tabular}

Sources: Chadian authorities; and IMF staff estimates. 


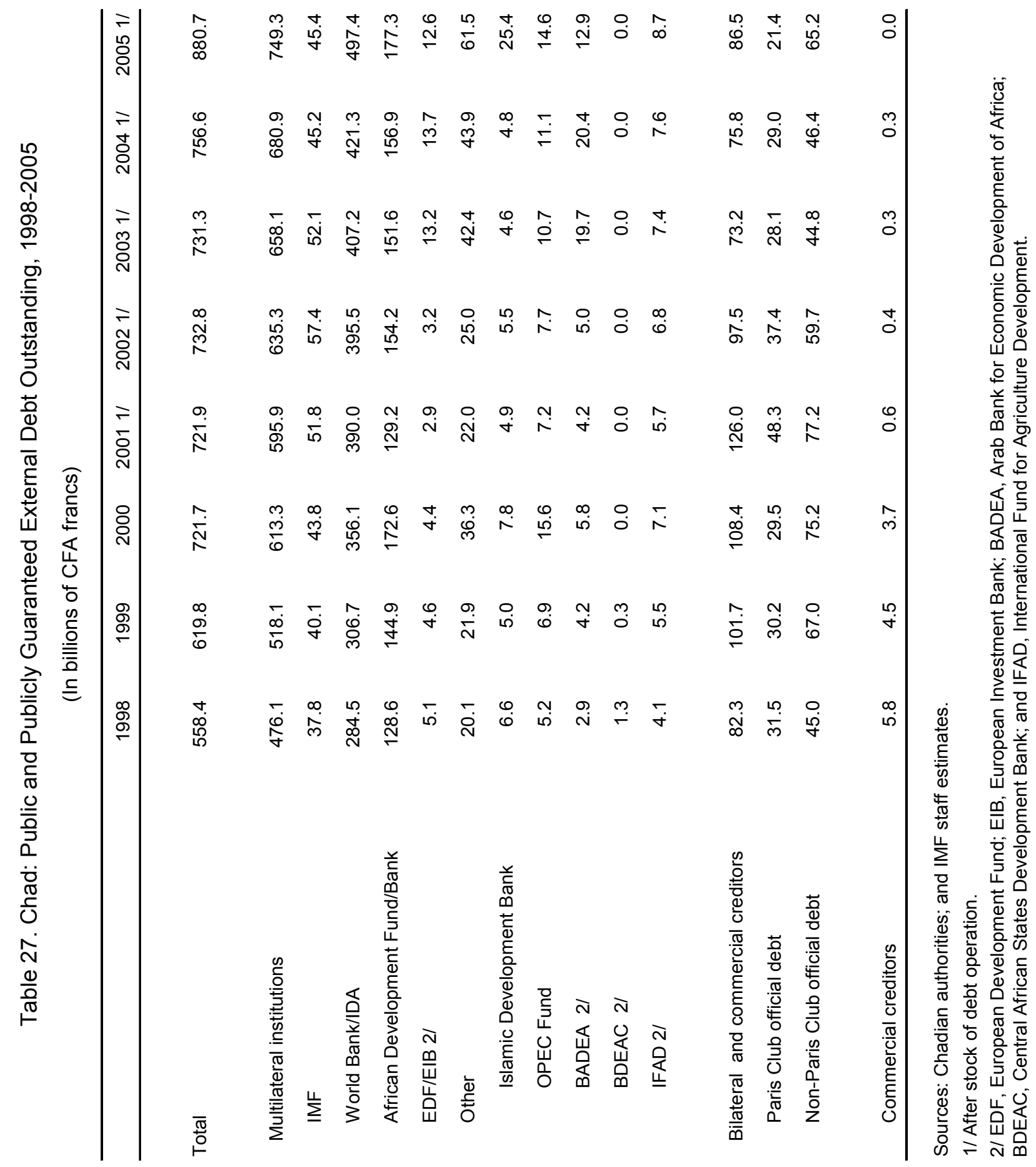




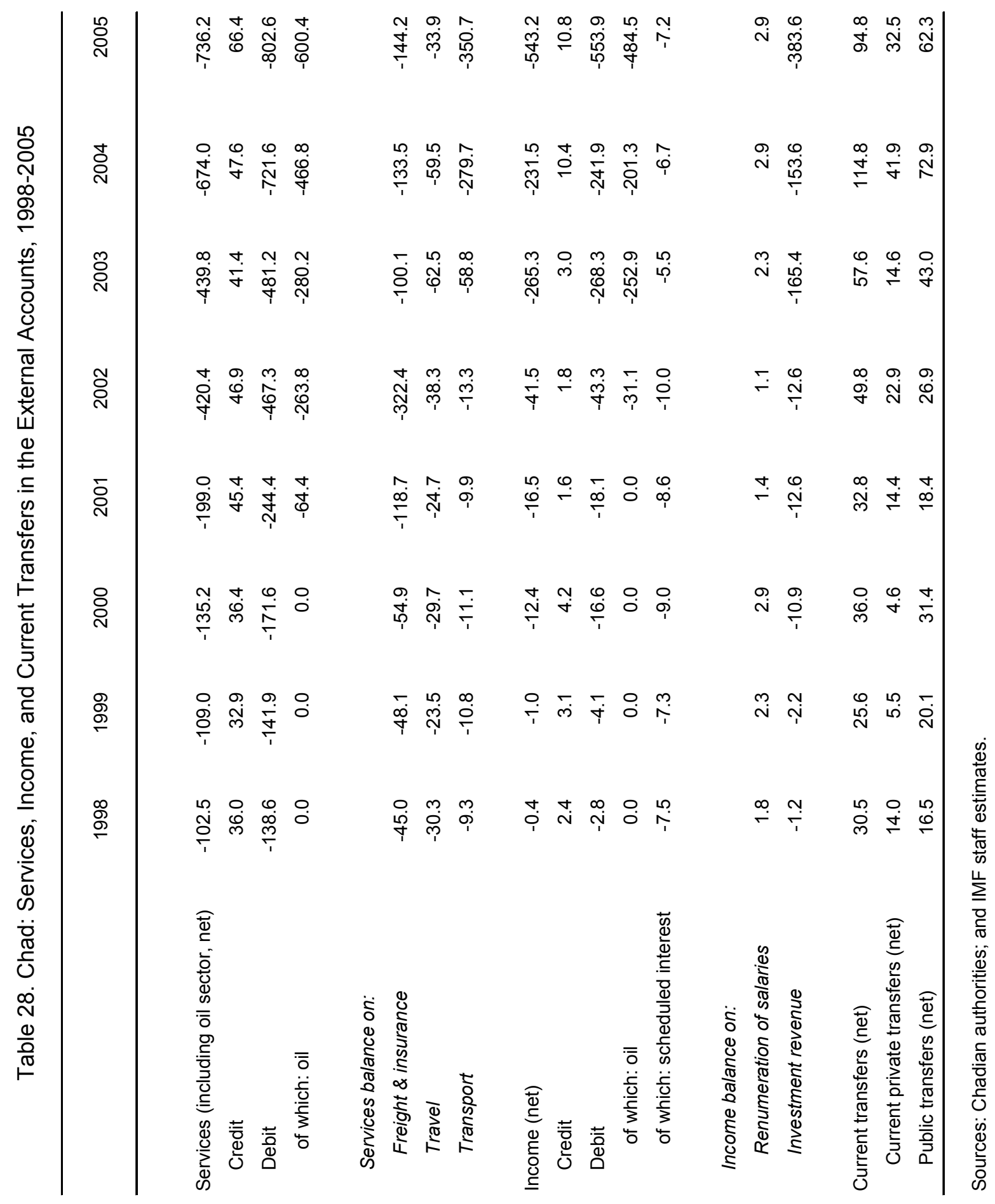


Table 29. Chad: Foreign Trade Indices, 1995-2005

(Index, $1995=100$, and percent change)

\begin{tabular}{|c|c|c|c|c|c|c|c|c|c|}
\hline & 1995 & 1998 & 1999 & 2000 & 2001 & 2002 & 2003 & 2004 & 2005 \\
\hline \multicolumn{10}{|l|}{ Export indices } \\
\hline Export value index & 100.0 & 127.3 & 115.6 & 107.3 & 114.1 & 106.3 & 288.9 & 941.8 & $1,351.7$ \\
\hline Changes in percent & 68.2 & 11.7 & -9.1 & -7.2 & 6.3 & -6.8 & 171.8 & 225.9 & 43.5 \\
\hline Export price index & 100.0 & 103.0 & 93.7 & 106.0 & 116.3 & 112.2 & 182.1 & 205.8 & 285.3 \\
\hline Changes in percent & 20.1 & 1.8 & -9.0 & 13.2 & 9.7 & -3.5 & 62.3 & 13.0 & 38.6 \\
\hline Implicit export volume ind $\epsilon$ & 100.0 & 121.8 & 121.6 & 96.9 & 93.6 & 90.5 & 189.6 & 593.3 & 622.4 \\
\hline Changes in percent & 92.8 & 9.9 & -0.1 & -20.4 & -3.4 & -3.4 & 109.6 & 212.9 & 4.9 \\
\hline \multicolumn{10}{|l|}{ Import indices } \\
\hline Import value index & 100.0 & 120.1 & 117.6 & 123.5 & 273.7 & 802.3 & 328.3 & 334.9 & 310.2 \\
\hline Changes in percent & 17.2 & 15.3 & -2.1 & 5.0 & 121.7 & 193.1 & -59.1 & 2.0 & -7.4 \\
\hline Import price index & 100.0 & 94.5 & 97.1 & 107.9 & 103.0 & 100.0 & 101.4 & 111.6 & 119.7 \\
\hline Changes in percent & 5.9 & -3.6 & 2.8 & 11.1 & -4.5 & -3.0 & 1.4 & 10.1 & 7.2 \\
\hline Implicit import volume ind & 100.0 & 125.2 & 119.1 & 111.8 & 253.0 & 748.9 & 295.8 & 271.9 & 232.2 \\
\hline Changes in percent & 12.8 & 18.9 & -4.9 & -6.1 & 126.2 & 196.1 & -60.5 & -8.1 & -14.6 \\
\hline Terms of trade & 100.0 & 109.0 & 96.5 & 98.3 & 112.9 & 112.3 & 179.6 & 184.4 & 238.4 \\
\hline Changes in percent & 13.4 & 5.7 & -11.5 & 1.9 & 14.8 & -0.5 & 60.0 & 2.7 & 29.3 \\
\hline \multicolumn{10}{|l|}{ Memorandum items: } \\
\hline Oil export price index & 100.0 & 86.3 & 129.8 & 246.9 & 222.5 & 173.3 & 200.1 & 201.7 & 295.5 \\
\hline Changes in percent & -2.2 & -35.2 & 50.4 & 90.2 & -9.9 & -22.1 & 15.5 & 0.8 & 46.5 \\
\hline Oil export volume index 1/ & 0.0 & 0.0 & 0.0 & 0.0 & 0.0 & 0.0 & 13.6 & 96.9 & 100.0 \\
\hline Changes in percent & & & & & & & & 614.4 & 3.2 \\
\hline Cotton export price index & 100.0 & 86.7 & 67.8 & 70.8 & 98.4 & 56.0 & 59.1 & 85.3 & 59.5 \\
\hline Changes in percent & 30.5 & 6.0 & -21.8 & 4.4 & 38.9 & -43.1 & 5.5 & 44.3 & -30.2 \\
\hline Cotton export volume index & 100.0 & 140.7 & 139.2 & 112.3 & 90.8 & 109.0 & 119.8 & 82.3 & 111.4 \\
\hline Changes in percent & 85.9 & 9.9 & -1.0 & -19.3 & -19.1 & 20.0 & 9.9 & -31.2 & 35.3 \\
\hline Livestock export price index & 100.0 & 144.0 & 144.0 & 158.4 & 162.3 & 166.5 & 230.4 & 265.2 & 273.1 \\
\hline Changes in percent & 46.5 & 4.5 & 0.0 & 10.0 & 2.4 & 2.6 & 38.4 & 15.1 & 3.0 \\
\hline Livestock export volume index & 100.0 & 136.7 & 120.1 & 124.2 & 123.0 & 144.0 & 235.7 & 242.2 & 248.0 \\
\hline Changes in percent & 1.1 & 11.8 & -12.1 & 3.4 & -0.9 & 17.1 & 63.6 & 2.8 & 2.4 \\
\hline
\end{tabular}

$1 /$ Index 2005=100

Sources: Bank of Central African States (BEAC); and IMF staff estimates. 
Table 30. Chad: Exchange Rates, 1997-Third Quarter 2005

(Quarterly averages)

\begin{tabular}{|c|c|c|c|c|c|c|}
\hline & \multicolumn{2}{|c|}{$\begin{array}{l}\text { CFA Francs per } \\
\text { U.S. Dollar }\end{array}$} & \multicolumn{2}{|c|}{$\begin{array}{l}\text { CFA Francs per } \\
\text { SDR }\end{array}$} & \multirow{2}{*}{$\begin{array}{c}\text { Nominal Effective } \\
\text { Exchange Rate } \\
\text { Index 1/ }\end{array}$} & \multirow{2}{*}{$\begin{array}{c}\text { Real Effective } \\
\text { Exchange Rate } \\
\text { Index } 1 /\end{array}$} \\
\hline & Rate & Index 1/ & Rate & Index 1/ & & \\
\hline \multicolumn{7}{|l|}{1998} \\
\hline First quarter & 612.5 & 109.8 & 823.1 & 103.9 & 105.0 & 116.3 \\
\hline Second quarter & 603.9 & 108.4 & 807.9 & 102.0 & 106.2 & 118.4 \\
\hline Third quarter & 583.8 & 106.4 & 786.4 & 99.3 & 107.4 & 125.3 \\
\hline Fourth quarter & 562.1 & 101.9 & 786.2 & 99.3 & 108.6 & 119.4 \\
\hline \multicolumn{7}{|l|}{1999} \\
\hline First quarter & 594.1 & 107.6 & 814.3 & 102.8 & 112.7 & 115.6 \\
\hline Second quarter & 627.2 & 113.6 & 842.2 & 106.3 & 110.9 & 111.5 \\
\hline Third quarter & 616.3 & 111.7 & 846.7 & 106.9 & 110.2 & 112.0 \\
\hline Fourth quarter & 643.4 & 116.6 & 884.2 & 111.6 & 109.3 & 111.2 \\
\hline \multicolumn{7}{|l|}{2000} \\
\hline First quarter & 677.3 & 122.7 & 911.9 & 115.1 & 107.6 & 111.0 \\
\hline Second quarter & 704.5 & 127.7 & 933.7 & 117.9 & 105.7 & 106.3 \\
\hline Third quarter & 731.5 & 132.6 & 954.8 & 120.5 & 104.8 & 104.0 \\
\hline Fourth quarter & 746.5 & 135.3 & 961.3 & 121.4 & 102.0 & 109.5 \\
\hline \multicolumn{7}{|l|}{2001} \\
\hline First quarter & 719.3 & 130.3 & 923.0 & 116.5 & 107.5 & 119.6 \\
\hline Second quarter & 762.0 & 138.1 & 956.4 & 120.7 & 105.9 & 118.0 \\
\hline Third quarter & 728.0 & 131.9 & 930.6 & 117.5 & 106.5 & 117.1 \\
\hline Fourth quarter & 735.7 & 133.3 & 932.0 & 117.7 & 106.9 & 114.1 \\
\hline \multicolumn{7}{|l|}{2002} \\
\hline First quarter & 756.5 & 137.1 & 940.8 & 118.8 & 106.7 & 114.5 \\
\hline Second quarter & 694.9 & 125.9 & 900.0 & 113.6 & 108.4 & 121.6 \\
\hline Third quarter & 667.6 & 121.0 & 884.1 & 111.6 & 111.3 & 128.8 \\
\hline Fourth quarter & 650.4 & 117.9 & 868.1 & 109.6 & 112.6 & 135.5 \\
\hline \multicolumn{7}{|l|}{2003} \\
\hline First quarter & 611.1 & 110.1 & 836.4 & 105.6 & 115.0 & 136.8 \\
\hline Second quarter & 577.8 & 104.1 & 807.5 & 101.9 & 117.4 & 129.6 \\
\hline Third quarter & 583.4 & 105.1 & 812.8 & 102.6 & 116.7 & 129.9 \\
\hline Fourth quarter & 551.8 & 99.4 & 797.1 & 100.6 & 118.6 & 127.0 \\
\hline \multicolumn{7}{|l|}{2004} \\
\hline First quarter & 524.6 & 94.5 & 780.0 & 98.5 & 120.4 & 130.0 \\
\hline Second quarter & 544.7 & 98.1 & 794.8 & 100.3 & 118.9 & 129.7 \\
\hline Third quarter & 536.8 & 96.7 & 787.7 & 99.4 & 119.6 & 126.5 \\
\hline Fourth quarter & 506.5 & 91.2 & 765.4 & 96.6 & 122.5 & 130.4 \\
\hline \multicolumn{7}{|l|}{2005} \\
\hline First quarter & 498.9 & 89.8 & 761.2 & 95.2 & 122.1 & 131.4 \\
\hline Second quarter & 521.0 & 93.8 & 780.9 & 100.2 & 120.3 & 130.4 \\
\hline Third quarter & 538.0 & 96.9 & 787.4 & 101.6 & 118.9 & 130.8 \\
\hline Fourth quarter & 552.0 & 99.4 & 792.4 & 102.2 & 117.9 & 131.0 \\
\hline \multicolumn{7}{|l|}{2006} \\
\hline First quarter & 545.7 & 98.3 & 785.3 & 101.3 & 118.3 & 133.8 \\
\hline Second quarter & 522.3 & 94.1 & 764.9 & 98.7 & 120.4 & 137.8 \\
\hline
\end{tabular}

Sources: IMFiternational Financial Stadistids,formation Notice System.

$1 / 1994=100$. 
Table 31. CEMAC: Indicators of Fiscal Balance, 1998-2005

(In percent of GDP)

\begin{tabular}{|c|c|c|c|c|c|c|c|c|}
\hline & 1998 & 1999 & 2000 & 2001 & 2002 & 2003 & 2004 & 2005 \\
\hline \multicolumn{9}{|c|}{ Overall fiscal balance (excluding grants) } \\
\hline Cameroon 1/ & -1.5 & -3.0 & 1.2 & 1.8 & 0.5 & 0.7 & -0.8 & 3.0 \\
\hline Central African Republic & -8.8 & -8.8 & -6.6 & -4.3 & -5.0 & -4.6 & -5.5 & -4.6 \\
\hline Chad & -7.5 & -10.7 & -12.5 & -10.3 & -12.1 & -14.1 & -6.0 & -3.8 \\
\hline Congo, Republic of & -20.3 & -6.3 & 0.8 & -0.9 & -8.3 & -0.1 & 3.6 & 22.1 \\
\hline Equatorial Guinea & -1.9 & -0.1 & 8.4 & 15.5 & 11.5 & -1.8 & 9.9 & 23.3 \\
\hline Gabon & -14.0 & 1.2 & 11.6 & 3.2 & 3.4 & 7.4 & 7.4 & 8.0 \\
\hline CEMAC & -7.3 & -3.2 & 2.8 & 1.6 & -0.3 & 0.2 & 1.8 & 7.9 \\
\hline \multicolumn{9}{|c|}{ Overall fiscal balance (including grants) } \\
\hline Cameroon 1/ & -1.2 & -2.9 & 1.2 & 2.1 & 1.8 & 1.4 & -0.5 & 3.5 \\
\hline Central African Republic & 0.0 & -0.5 & -1.8 & -0.9 & -1.2 & -3.1 & -2.2 & -2.5 \\
\hline Chad & -2.8 & -6.4 & -7.0 & -4.6 & -6.4 & -6.1 & -2.2 & -1.0 \\
\hline Congo, Republic of & -20.0 & -5.9 & 1.1 & -0.7 & -8.1 & 0.4 & 3.9 & 22.1 \\
\hline Equatorial Guinea & -1.3 & 0.3 & 8.4 & 15.5 & 11.5 & -1.7 & 9.9 & 23.3 \\
\hline Gabon & -14.0 & 1.2 & 11.6 & 3.2 & 3.5 & 7.4 & 7.4 & 8.0 \\
\hline CEMAC & -6.3 & -2.7 & 3.4 & 2.3 & 0.9 & 1.3 & 2.5 & 8.5 \\
\hline \multicolumn{9}{|c|}{ Government revenue (excluding grants) } \\
\hline Cameroon 1/ & 14.3 & 13.7 & 16.5 & 18.4 & 16.2 & 16.0 & 15.2 & 17.2 \\
\hline Central African Republic & 9.3 & 9.4 & 8.9 & 8.9 & 10.8 & 7.7 & 8.1 & 8.2 \\
\hline Chad & 7.4 & 8.2 & 8.1 & 7.3 & 8.1 & 7.9 & 8.5 & 9.3 \\
\hline Congo, Republic of & 22.6 & 26.5 & 26.3 & 30.7 & 27.2 & 29.1 & 32.2 & 53.1 \\
\hline Equatorial Guinea & 26.3 & 20.0 & 21.0 & 28.0 & 28.5 & 28.7 & 34.4 & 42.9 \\
\hline Gabon & 34.5 & 28.3 & 33.4 & 34.0 & 31.5 & 29.7 & 28.8 & 28.3 \\
\hline CEMAC & 19.1 & 18.1 & 21.4 & 22.9 & 20.9 & 20.5 & 21.1 & 25.8 \\
\hline \multicolumn{9}{|l|}{ Government total expenditure } \\
\hline Cameroon 1/ & 15.8 & 16.7 & 15.3 & 16.6 & 15.7 & 15.3 & 16.0 & 14.3 \\
\hline Central African Republic & 18.1 & 18.2 & 15.5 & 13.2 & 15.8 & 12.3 & 13.5 & 12.8 \\
\hline Chad & 14.9 & 18.9 & 20.6 & 17.6 & 20.2 & 22.0 & 14.4 & 13.0 \\
\hline Congo, Republic of & 42.9 & 32.8 & 25.5 & 31.5 & 35.5 & 29.3 & 28.6 & 31.0 \\
\hline Equatorial Guinea & 28.2 & 20.2 & 12.6 & 12.5 & 17.0 & 30.5 & 24.5 & 19.6 \\
\hline Gabon & 48.5 & 27.2 & 21.7 & 30.8 & 28.0 & 22.4 & 21.4 & 20.3 \\
\hline CEMAC & 26.5 & 21.3 & 18.6 & 21.3 & 21.2 & 20.3 & 19.3 & 17.9 \\
\hline
\end{tabular}

Source: IMF staff estimates.

1/ Fiscal year July 1-June 30. 
145

Table 32. CEMAC: Indicators of External Balance, 1998-2005

(In percent of GDP)

\begin{tabular}{|c|c|c|c|c|c|c|c|c|}
\hline & 1998 & 1999 & 2000 & 2001 & 2002 & 2003 & 2004 & 2005 \\
\hline \multicolumn{9}{|l|}{ Exports of goods } \\
\hline Cameroon 1/ & 17.5 & 15.5 & 20.4 & 18.9 & 17.1 & 17.5 & 16.3 & 17.8 \\
\hline Central African Republic & 14.7 & 14.3 & 16.2 & 14.7 & 13.9 & 10.5 & 9.6 & 9.3 \\
\hline Chad & 15.0 & 14.8 & 13.2 & 11.0 & 9.3 & 22.1 & 49.0 & 52.7 \\
\hline Congo, Republic of & 70.2 & 66.1 & 76.1 & 71.1 & 75.4 & 72.9 & 78.2 & 109.9 \\
\hline Equatorial Guinea & 93.6 & 98.0 & 103.7 & 102.4 & 101.6 & 99.1 & 99.5 & 105.5 \\
\hline Gabon & 42.5 & 53.6 & 65.3 & 55.6 & 51.5 & 52.4 & 57.5 & 62.7 \\
\hline CEMAC & 29.8 & 33.0 & 43.7 & 39.5 & 38.2 & 39.0 & 45.4 & 54.3 \\
\hline \multicolumn{9}{|l|}{ Imports of goods } \\
\hline Cameroon 1/ & 15.3 & 14.9 & 16.0 & 19.4 & 17.4 & 15.6 & 16.7 & 16.4 \\
\hline Central African Republic & 14.2 & 12.6 & 12.3 & 11.1 & 12.0 & 9.9 & 10.7 & 10.7 \\
\hline Chad & 16.1 & 17.2 & 17.3 & 30.2 & 79.9 & 28.6 & 19.8 & 13.8 \\
\hline Congo, Republic of & 28.6 & 22.2 & 18.5 & 24.4 & 23.4 & 22.7 & 24.8 & 28.4 \\
\hline Equatorial Guinea & 95.8 & 59.3 & 42.7 & 47.7 & 24.3 & 45.6 & 33.1 & 28.2 \\
\hline Gabon & 25.9 & 19.5 & 15.7 & 18.0 & 18.9 & 17.2 & 18.7 & 16.7 \\
\hline CEMAC & 20.8 & 18.5 & 17.7 & 22.4 & 24.0 & 20.6 & 19.9 & 18.7 \\
\hline \multicolumn{9}{|c|}{ External current account (including grants) } \\
\hline Cameroon $1 /$ & -2.6 & -3.8 & -1.6 & -3.5 & -5.2 & -2.0 & -3.4 & -1.5 \\
\hline Central African Republic & -6.1 & -1.6 & -3.0 & -2.5 & -3.4 & -4.7 & -4.5 & -4.1 \\
\hline Chad & -8.1 & -11.3 & -15.4 & -33.7 & -100.4 & -47.4 & -4.8 & 0.9 \\
\hline Congo, Republic of & -20.6 & -17.2 & 7.9 & -5.6 & 0.6 & 1.0 & 2.3 & 18.8 \\
\hline Equatorial Guinea & -89.3 & -29.9 & -16.4 & -49.0 & -13.5 & -43.8 & -24.2 & -13.3 \\
\hline Gabon & -13.8 & 8.4 & 19.8 & 11.0 & 6.8 & 12.0 & 9.9 & 15.7 \\
\hline CEMAC & -9.5 & -3.9 & 3.2 & -6.6 & -10.5 & -7.0 & -3.1 & 2.7 \\
\hline \multicolumn{9}{|c|}{ External current account (excluding grants) } \\
\hline Cameroon $1 /$ & -2.8 & -4.0 & -1.6 & -3.9 & -6.5 & -2.6 & -3.6 & -2.0 \\
\hline Central African Republic & -9.6 & -5.7 & -6.5 & -5.2 & -5.8 & -5.6 & -6.6 & -6.0 \\
\hline Chad & -9.8 & -13.4 & -18.6 & -35.2 & -102.3 & -50.1 & -7.9 & -1.2 \\
\hline Congo, Republic of & -21.0 & -17.2 & 7.6 & -5.8 & 0.4 & 0.8 & 2.1 & 18.6 \\
\hline Equatorial Guinea & -91.8 & -31.2 & -17.1 & -49.8 & -14.2 & -44.4 & -24.7 & -13.6 \\
\hline Gabon & -14.5 & 7.9 & 20.0 & 10.8 & 7.5 & 12.8 & 9.8 & 15.6 \\
\hline CEMAC & -6.0 & -2.8 & 2.0 & -5.2 & -7.9 & -4.3 & -2.0 & 1.1 \\
\hline
\end{tabular}

Source: IMF staff estimates.

1/ Fiscal year July 1-June 30. 
Table 33. CEMAC: External Public Debt, 1998-2005

\begin{tabular}{|c|c|c|c|c|c|c|c|c|}
\hline & 1998 & 1999 & 2000 & 2001 & 2002 & 2003 & 2004 & 2005 \\
\hline & \multicolumn{8}{|c|}{ (In percent of GDP) } \\
\hline \multicolumn{9}{|l|}{ External public debt } \\
\hline Cameroon $1 /$ & 81.1 & 83.3 & 80.4 & 73.2 & 49.9 & 46.8 & 40.3 & 32.8 \\
\hline Central African Republic & 83.9 & 82.4 & 80.3 & 93.9 & 91.4 & 93.9 & 86.9 & 82.8 \\
\hline Chad & 54.2 & 65.6 & 74.2 & 57.6 & 52.9 & 46.2 & 32.4 & 28.3 \\
\hline Congo, Republic of & 264.4 & 231.6 & 164.9 & 192.8 & 200.9 & 215.6 & 212.9 & 127.1 \\
\hline Equatorial Guinea & 59.7 & 61.1 & 36.3 & 24.8 & 10.2 & 10.1 & 6.2 & 3.8 \\
\hline Gabon & 84.9 & 79.7 & 57.0 & 64.2 & 65.6 & 59.1 & 53.8 & 42.7 \\
\hline CEMAC & 97.4 & 97.3 & 84.6 & 82.7 & 71.2 & 68.2 & 59.8 & 40.6 \\
\hline \multicolumn{9}{|c|}{ (In percent of exports of goods and services) } \\
\hline External public debt & & & & & & & & \\
\hline Cameroon $1 /$ & 462.4 & 536.8 & 394.8 & 386.7 & 291.6 & 268.0 & 246.3 & 184.0 \\
\hline Central African Republic & 571.5 & 577.7 & 494.7 & 639.9 & 655.5 & 893.6 & 908.7 & 894.0 \\
\hline Chad & 361.8 & 442.1 & 562.2 & 521.8 & 568.5 & 208.7 & 66.2 & 53.7 \\
\hline Congo, Republic of & 376.5 & 350.5 & 216.7 & 271.2 & 266.5 & 295.7 & 272.3 & 115.6 \\
\hline Equatorial Guinea & 63.8 & 62.3 & 35.0 & 24.2 & 10.0 & 10.2 & 6.3 & 3.6 \\
\hline Gabon & 199.6 & 148.8 & 87.2 & 115.6 & 127.3 & 112.9 & 93.5 & 68.1 \\
\hline CEMAC & 327.3 & 294.5 & 193.8 & 209.3 & 186.5 & 174.9 & 131.7 & 74.8 \\
\hline \multicolumn{9}{|c|}{ (In percent of government revenue) } \\
\hline \multicolumn{9}{|l|}{ Debt service } \\
\hline Cameroon $1 /$ & 53.4 & 29.5 & 22.1 & 17.2 & 15.5 & 13.0 & 10.8 & 24.9 \\
\hline Central African Republic & 17.1 & 9.5 & 9.3 & 11.1 & 1.6 & 0.2 & 5.6 & 0.0 \\
\hline Chad & 37.7 & 84.9 & 55.6 & 55.4 & 23.8 & 13.8 & 9.1 & 1.3 \\
\hline Congo, Republic of & 18.7 & 22.2 & 23.7 & 21.4 & 28.1 & 15.5 & 15.9 & 21.1 \\
\hline Equatorial Guinea & 14.7 & 16.2 & 4.1 & 2.6 & 1.2 & 1.5 & 0.8 & 0.5 \\
\hline Gabon & 31.6 & 34.3 & 32.0 & 44.4 & 33.5 & 58.4 & 30.1 & 8.1 \\
\hline CEMAC & 24.8 & 21.8 & 16.1 & 17.7 & 16.8 & 18.0 & 12.8 & 10.9 \\
\hline
\end{tabular}

Source: IMF staff estimates.

1/ Fiscal year July 1-June 30. 